\title{
Identidades brasileiras
}

composições e recomposições

\author{
Cristina Carneiro Rodrigues \\ Tania Regina de Luca \\ Valéria Guimarães \\ (Orgs.)
}

\section{SciELO Books / SciELO Livros / SciELO Libros}

RODRIGUES, CC., LUCA, TR., and GUIMARÃES, V., orgs. Identidades brasileiras: composições e recomposições [online]. São Paulo: Editora UNESP; São Paulo: Cultura Acadêmica, 2014, 257 p. Desafios Contemporâneos collection. ISBN 978-85-7983-515-5. Available from SciELO Books $<\underline{\text { http://books.scielo.org }>\text {. }}$

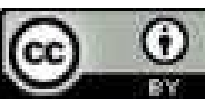

All the contents of this work, except where otherwise noted, is licensed under a Creative Commons Attribution 4.0 International license.

Todo o conteúdo deste trabalho, exceto quando houver ressalva, é publicado sob a licença Creative Commons Atribição $\underline{4.0}$.

Todo el contenido de esta obra, excepto donde se indique lo contrario, está bajo licencia de la licencia Creative Commons Reconocimento 4.0. 
CRISTINA CARNEIRO RODRIGUES

TANIA REGINA DE LUCA

VALÉRIA GUIMARÃES

(ORGS.)

CULTURA

ACADÊMICA

\section{IDENTIDADES}

\section{BRASILEIRAS}

COMPOSIÇÕES E RECOMPOSIÇÕES

DES A F I O S C O NTEMPOR A NE O S

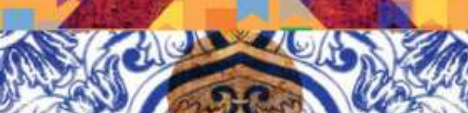
V.

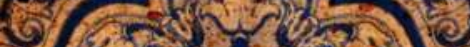

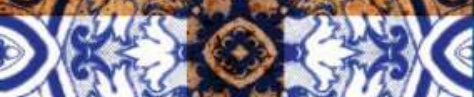

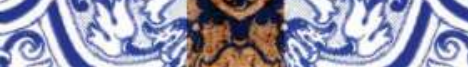
A 29 ( (13)

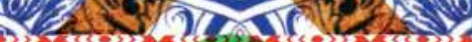

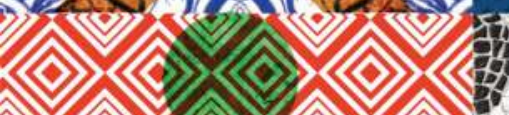
()) (-) (-) (-) (-)
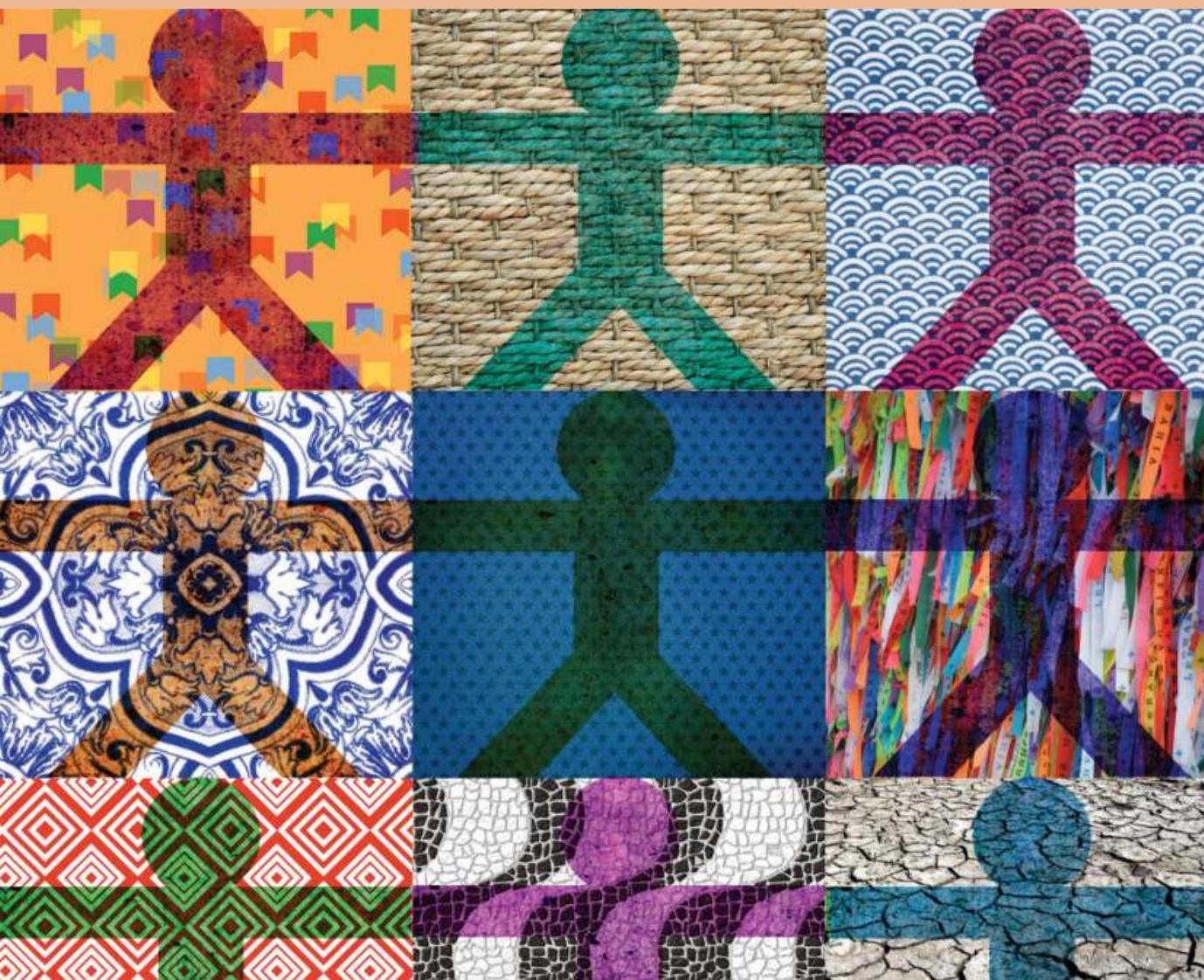
24ล

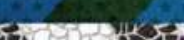
ficin sil

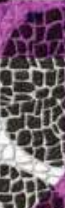

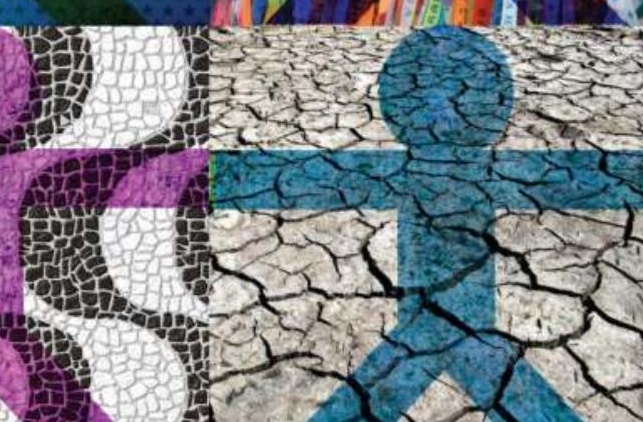




\section{IDENTIDADES BRASILEIRAS}


CRISTINA GARNEIRO RODRIGUES

TANIA REGINA DE LUCA

VALÉRIA GUIMARÃES

(Organizadoras)

\section{IDENTIDADES BRASILEIRAS COMPOSIÇÕES E RECOMPOSIÇÕES}

Coleção Desafios Contemporâneos

Pró-Reitoria de Pesquisa

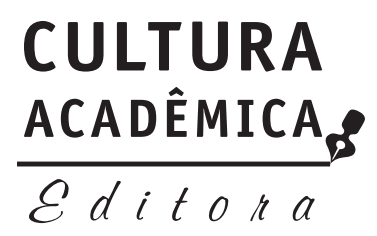


C 2013 Cultura Acadêmica

Direitos de publicação reservados à:

Cultura Acadêmica

Praça da Sé, 108

01001-900 - São Paulo - SP

Tel.: (0xx11) 3242-7171

Fax: (0xx11) 3242-7172

www.editoraunesp.com.br

www.culturaacademica.com.br

feu@editora.unesp.br

CIP - Brasil. Catalogação na publicação

Sindicato Nacional dos Editores de Livros, RJ

122

Identidades brasileiras: composições e recomposições / organização Cristina Carneiro Rodrigues, Tania Regina de Luca, Valéria Guimarães. 1. ed. - São Paulo: Cultura Acadêmica, 2014. (Desafios contemporâneos)

il.; $21 \mathrm{~cm}$.

ISBN 978-85-7983-515-5

1. Características nacionais brasileiras. I. Rodrigues, Cristina Carneiro. II. Luca, Tania Regina de. III. Guimarães, Valéria. IV. Série.

14-09736

CDD: 306.089698

CDU: 306.089698

Editora afiliada:

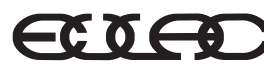

Asociación de Editoriales Universitarias de América Latina y el Caribe

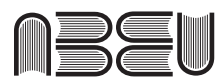

Associação Brasileira de Editoras Universitárias 


\section{Sumário}

Apresentação 1

Introdução 3

Tania Regina de Luca

Revisitando o conceito de identidade nacional 7

Jean Carlos Moreno

A libertação de Cam: discriminar para igualar.

Sobre a questão racial brasileira 31

Maria Bernardete Ramos Flores, Sabrina Fernandes Melo

Das relações com o corpo no Brasil 87

Jean Marcel Carvalho França, Ana Carolina de Carvalho Viotti

Língua no Brasil: variação e multilinguismo 117

Cristina Carneiro Rodrigues

A passeata contra a guitarra e a "autêntica" música brasileira 145

Valéria Guimarães

Brasil: três projetos de identidade religiosa 175

Artur Cesar Isaia 
$\mathrm{VI}$ CRISTINA C. RODRIGUES - TANIA R. DE LUCA - VALÉRIA GUIMARÃES (ORGS.)

Os novos intérpretes e a velha questão:

o que é o Brasil? 203

Karina Anhezini, Ricardo Alexandre Ferreira

Referências bibliográficas 233 


\section{Apresentação}

A coleção Desafios Contemporâneos proposta pela Pró-Reitoria de Pesquisa (PROPe) da Unesp tem por objetivo disponibilizar, em linguagem acessível aos não familiarizados com o jargão dominante nos estudos especializados e sem prejuízo do rigor científico, ensaios a respeito de temas de amplo interesse da sociedade brasileira. Assim, a universidade cumpre uma de suas tarefas essenciais: a difusão dos resultados do conhecimento que produz.

Neste volume, dedicado às questões sociais, os autores enfrentaram a difícil tarefa de lançar um olhar panorâmico sobre a complexa questão da identidade brasileira, sem perder de vista a maneira como a temática se expressa nos dilemas enfrentados nos dias que correm.

Estruturados em amplos recortes, os textos tomam como ponto de partida o momento atual para delinear um balanço retrospectivo da produção sobre o assunto, pontuando o estado atual das pesquisas e para dialogar com as abordagens mais clássicas, com o intuito de apontar possíveis desdobramentos para a pesquisa na área das Ciências Humanas. 
2 CRISTINA C. RODRIGUES - TANIA R. DE LUCA - VALÉRIA GUIMARÃES (ORGS.)

O que se oferece ao leitor é o resultado desse esforço coletivo, que objetiva contribuir para a reflexão acerca dos desafios atuais a partir de seu enquadramento em amplas perspectivas, sem abandonar a dupla dimensão da qualidade e da complexidade, tendo em vista que seu alvo privilegiado é o grande público e não o especialista. 


\title{
Introdução
}

\author{
Tania Regina de Luca ${ }^{1}$ \\ Unesp/CNPq
}

A questão da identidade nacional continua a desafiar os estudiosos das Ciências Humanas; basta observar os conflitos em curso nesta segunda década do século XXI para perceber o quanto projetos identitários de cunho geográfico, étnico, linguístico, religioso e cultural continuam a se mesclar num jogo complexo a despeito da globalização e de seus efeitos homogeneizadores. Esse cenário convida a revisitar o debate sobre a identidade brasileira, tema que tem ocupado a nossa intelectualidade desde a Independência.

Não nos faltam estudos específicos - dedicados a perscrutar instituições, personagens, períodos e eventos - com o intuito de dar conta da nação brasileira, seus impasses e desafios, avanços e recuos que assumiram formas muito variadas no decorrer do tempo. Igualmente ricos são os balanços e as análises que pas-

1 Professora livre-docente do curso e programa de pós-graduação em História da Universidade Estadual Paulista "Júlio de Mesquita Filho" (Unesp), câmpus de Assis, bolsista do CNPq (PQ-1B), pesquisadora principal no projeto temático A circulação transatlântica dos impressos: a globalização da cultura no século XIX (Fapesp 2011-2015). Publicou, entre outros, Leituras, projetos e (re)vista(s)do Brasil (Editora Unesp, 2011).E-mail: trdeluca@uol.com.br. 
sam em revista interpretações e intérpretes do Brasil. Os ensaios especialmente produzidos para este livro particularizam-se, em primeiro lugar, por adotar uma perspectiva ampla, do ponto de vista temporal e temático. Não se trata de indagar sobre um autor ou uma conjuntura específica, por mais importantes que sejam, mas de fornecer grandes linhas que contribuam para responder às indagações "o que é o Brasil?" e "quem são os brasileiros?”, tendo como horizonte a compreensão dos desafios - sociais, políticos, econômicos e culturais - contemporâneos.

O livro abre-se com um capítulo que apresenta um balanço acerca das diferentes formas de entender a identidade nacional, a partir da confrontação dos principais pensadores que se dedicaram ao exame do conceito no campo das humanidades, com particular ênfase na historiografia, além de discutir os sentidos assumidos pelas representações identitárias no contexto contemporâneo.

Em seguida, o Brasil entra em cena e o caminho escolhido foi o de privilegiar cinco núcleos temáticos: a questão racial, o corpo, a língua, a religião e a cultura. No primeiro deles, o leitor encontrará densa discussão a respeito dos sentidos atribuídos à presença negra e à miscigenação, que bem evidencia as diferentes percepções da questão e seus deslocamentos no pensamento social brasileiro ao longo de quase dois séculos. Acrescente-se, ainda, a reflexão sobre o comparecimento/ausência da cor da pele nos nossos censos, questão com significativa fortuna crítica aqui atualizada a partir da discussão dos dados mais recente, da ação dos movimentos negros desde a abolição e das medidas recentes de ação afirmativa, que seguem dando margem a debates acalorados no âmbito da sociedade brasileira.

Nas últimas décadas do século XX, os estudos sobre o corpo ganharam importância, num contexto marcado pela contestação de valores e costumes, o que está longe de significar que o afã de controlar e vigiar tenha surgido nesse momento, como bem evidencia o capítulo dedicado ao assunto, que se concentra na 
doença e na saúde. Os autores nos convidam a percorrer, num voo de larga amplitude, três modos distintos de conceber a manutenção dos corpos e a cura de seus males: o místico, o medicalizado e o jovem, num percurso nada retilíneo, que se inicia no período colonial e desemboca no atualíssimo debate sobre o Ato Médico (2013), que adquire novos contornos à luz desse amplo ângulo de visada.

O trabalho de eruditos e gramáticos foi essencial para a definição das línguas literárias, encarregadas de expressar formas específicas de sentir e pensar, um dos pilares do conceito de nação, tal como definido na Europa desde a modernidade. Esse esforço de sistematização e ordenação impôs silêncios que continuam a ser problematizados, mesmo depois de passados vários séculos - e a questão basca é apenas um entre muitos exemplos que poderiam ser evocados. Para grande parte dos brasileiros, a língua não se coloca como um campo de disputas, ao contrário, parece assente que o português é e sempre foi a língua por todos compartilhada. Tal "verdade" é posta à prova no capítulo dedicado ao tema, que problematiza tal crença, assim como a pretensa homogeneidade do português falado no Brasil, colocando no centro da cena o preconceito linguístico, poderosa ferramenta de discriminação, como atestam os exemplos apresentados no texto. De outra parte, as quase duas centenas de línguas indígenas, patrimônio das comunidades que habitam o país, correm sério risco de desaparecer, a despeito das garantias da Constituição de 1988. Ao referir-se à visão do outro, construída pela Europa desde os tempos modernos, Romain Bertrand (2011, p.11-12) lamentou o fato de não sabermos quase nada das mil e uma maneiras de ser humano e de construir sociedades, observação que não parece descabida em relação aos povos que habitam o território brasileiro.

A preocupação de estabelecer um rol de atributos particulares, que possam ser tidos como "autenticamente" nacionais, não se restringe à língua e à literatura. A passeata contra a guitarra, em meados de 1967, foi a porta de entrada para refletir sobre a 
tensão nacional/estrangeiro que tem atravessado, com matizes e graus diversos, a cultura brasileira. Num mundo interconectado e marcado pela simultaneidade das informações e grandes corporações do entretenimento, que não conhecem fronteiras, a noção de trocas culturais - entendida como uma via de mão dupla - apresenta-se como uma possibilidade instigante.

A questão da identidade religiosa, por sua vez, constitui-se num dos temas mais candentes do cenário brasileiro atual, com repercussões no jogo político-partidário, na economia, na cultura, nos meios de comunicação de massa e na vida cotidiana das pessoas. Os dados censitários são eloquentes quando se trata de evidenciar a pluralização das formas de identificação da população. No ensaio consagrado ao tema, confrontam-se três projetos de identificação e analisam-se suas narrativas fundacionais: o católico, o umbandista e o pentecostal.

O capítulo final, a exemplo do que ocorreu no de abertura, objetiva fornecer um balanço, e a opção aqui foi a de examinar um elenco representativo de coletâneas publicadas no início do novo milênio, com o intuito de analisar as formas de utilização e apropriação do conceito de identidade nacional pelos pesquisadores brasileiros que se dedicam ao tema.

Este livro foi concebido para ser disponibilizado em ambiente virtual, o que coloca novos desafios para o processo de escrita e para o trabalho editorial. Não parece despropositado afirmar que ainda temos um longo caminho até que se produza material que explore, de forma efetiva, todas as possibilidades desse novo suporte. Aqui não se foi além de solicitar aos autores que, sempre que possível e pertinente, indicassem material disponível na rede mundial, ainda figurando na sua forma tradicional de nota de rodapé, isso porque não foi possível dar acesso direto aos documentos, trechos de música ou excertos de imagens em movimento. Escrever, de fato, no e para esse novo meio é um desafio que continuamos a enfrentar. 


\title{
Revisitando o conceito de identidade nacional
}

\author{
Jean Carlos Moreno ${ }^{1}$
}

\begin{abstract}
Os diversos sujeitos sociais conduzem suas experiências por representações - atribuídas, autoatribuídas e compartilhadas a respeito de quem são e de quem podem ou desejam ser. Essencialmente conflitiva, envolvendo interação social, afetos, autoestima e jogos de poder, ${ }^{2}$ a identidade é uma categoria social discursivamente construída, expressa e percebida por diferentes linguagens: escritas, corporais, gestuais, imagéticas, midiáticas.
\end{abstract}

1 Professor adjunto do colegiado de História da Universidade Estadual do Norte do Paraná (UENP) e doutor em História pela Universidade Estadual Paulista "Júlio de Mesquita Filho" (Unesp). Publicou, dentre outros, Quem somos nós: apropriações e representações sobre a(s) identidade(s) brasileira(s) em livros didáticos de História (Paco Editorial, 2014).E-mail: jeanmoreno@uenp.edu.br.

2 Os discursos sobre identidade podem ser interpretados como um exercício de poder simbólico - firmado no reconhecimento - que produz a existência daquilo que enuncia, como bem já demonstrou Bourdieu (1989). A abordagem sobre esse poder, essa magia social - tentar trazer à existência a coisa nomeada -, faz parte do convite de Bourdieu aos pesquisadores para incluir, no que se entende por real, a representação do real, ou, melhor, a luta por - e entre representações que têm por fim impor sentido e consenso. "As lutas a respeito da identidade são um caso particular nas lutas das classificações, pelo monopólio de fazer ver e fazer crer, de dar a conhecer e de fazer reconhecer, de impor a definição legítima das divisões do mundo social e, por este meio, de fazer e desfazer os grupos" (idem, p.113). 
Mais incisivamente do que a noção de cultura, a identidade implica a produção de discursos portadores de signos de identificação. Nem sempre um grupo com uma cultura em comum percebe-se, denomina-se, reconhece-se ou é objeto de discursos identitários. A identidade estaria ligada, desta forma, à representação da cultura de um ou mais grupos humanos. Essa constatação leva o influente sociólogo contemporâneo, Manuel Castells (1996, p.26), a definir a identidade como um "processo de construção de significado com base em um atributo cultural ou ainda um conjunto de atributos culturais inter-relacionados, o(s) qual(ais) prevalece(m) sobre outras fontes de significado". Essa construção se serve, também, de diversas matérias-primas fornecidas pela história, geografia, biologia, pela memória coletiva, pelos aparatos de poder etc.

Se o discurso não cria, ele, ao menos, organiza a diferença, produzindo identidades que se consolidam em processos sociais e se expressam por meio de ações simbólicas, textos e contextos. Compreender a identidade como figura discursiva significa entendê-la como criatura da linguagem (Silva, 2009b), ato de criação linguística, uma espécie de metadiscurso sobre experiências históricas (Diehl, 2002, p.128), uma construção que se narra (Canclini, 1995, p.139). Essas narrativas orientam as ações humanas, funcionando como construção, afirmação, imposição ou depreciação das identidades sociais.

Sendo um texto representativo cujos autores são, necessariamente, sujeitos sociais, a construção social da identidade acontece sempre num contexto de relações de poder. Todavia, ainda que as identidades possam, também, ser estruturadas a partir de instituições dominantes, é forçoso reconhecer, com Lilia Moritz Schwarcz, que

o sentido da identidade não é o espaço do aleatório, mas parte de um universo cultural reconhecível e compartilhado [...] seu "sucesso" 
está ligado a uma comunidade de sentidos e à possibilidade de serem [os símbolos que estruturam os discursos identitários] ao mesmo tempo, inteligíveis e partilhados. (Schwarcz, 2003, p.384)

As identidades são sempre construção, mas não necessariamente invenção no sentido de um ato de poder deliberado, conscientemente imposto e assimilado integralmente.

De fato, a identidade é sempre algo muito evasivo e escorregadio na imaginação sociológica (Cf. Bauman, 2005), contudo ela se torna concreta nos discursos sociais, ou melhor, nas práticas discursivas, nas quais se verifica que, junto com um discurso acadêmico e reivindicações que tomam a identidade num viés pluralista, convivem outras formas de interpretação/ação discursiva, inclusive posturas que se costuma chamar de essencialistas. Por vezes, é através dessas posturas que a identidade é objetivada nos usos sociais.

Nas percepções essencialistas as identidades aparecem como realidades perenes, estáveis, definitivas, homogêneas e inatas. Um processo de categorização social, presente nas práticas discursivas, simplifica as diferenças e tende a dirimir as contradições, construindo representações de identidades imanentes. Embora no nível das representações a identidade tenha sempre que estar ligada a uma continuidade no tempo, nos discursos essencialistas esse tempo é congelado, mitificado, e as especificidades culturais tornam-se um fato social, pouco suscetível a mudanças.

As análises contemporâneas destacam o embate entre esses dois posicionamentos a respeito das representações das identidades. Nas posições essencialistas a noção de identidade (ou de identificação) acaba por tomar o lugar de uma acepção de "natureza humana vista como um legado durável e que não deveria ser revogado" (Bauman, 2008, p.180). Numa outra compreensão, percebe-se que as categorias sociais - a nacionalidade, o gênero e a classe - que eram utilizadas, quase como sendo evidentes ou naturais, para atribuir identidades aos diferentes sujeitos são 
colocadas em xeque e iluminadas tanto pelas práticas sociais quanto pelas lentes acadêmicas, evidenciando que as identidades sociais são múltiplas, maleáveis e estão em constante transformação. ${ }^{3}$ Diferenças, antes obscurecidas por essas macrocategorizações, proporcionariam, simultaneamente, novas identificações globais e novas identificações locais, reforçando outros laços e lealdades culturais "acima" e "abaixo" do nível do Estado-nação (Cf. Hall, 2006, p.67).

Todavia, se a crescente complexidade das dinâmicas sociais e a aceleração das transformações tornam mais visível a identidade nacional como um construto discursivo - com suas contradições e lacunas -, é interessante perceber, no lado oposto, a longevidade das representações em torno das identidades nacionais, demarcando ainda um "território de imaginação" por onde as disputas materiais e simbólicas se estabelecem.

\section{O debate em torno das identidades nacionais}

A nação, como "princípio de visão e di-visão" (Bourdieu, 1989) da organização política e social, tornou-se elemento onipresente como "principal fonte de identidade cultural na modernidade" (Hall, 2006, p.47). No decorrer dos séculos XIX e XX, a identidade nacional paulatinamente se deslocou para o campo das representações já consolidadas, capaz de ser fundamento para a mobilização política e ideológica, ${ }^{4}$ envolvendo, inclusive,

3 Como todas as identidades estão localizadas no espaço e no tempo simbólicos, a percepção deste aspecto multidimensional das identidades leva os pesquisadores a destacar sua fluidez e dinamicidade e, especialmente, a sua dimensão histórica, apesar da aparente constante temporal. O que passa a ser questionada, no âmbito acadêmico, é a maneira de ler, interpretar e representar as identidades.

4 O discurso nacionalista, por vezes, reifica a nação tornando-lhe até mesmo um sujeito social dotado de individualidade. Essa "personalização" inclui, para Luís Fernando Cerri, um tratamento dado à nação como indivíduo dotado de 
fatores emocionais e afetivos como a segurança, as certezas, as esperanças e, até mesmo, a fé, tornando-se importante elo explicativo para a relação entre o passado, o presente e o futuro. Esse fenômeno capaz de gerar vinculações tão profundas é fruto - ambíguo, por certo - de relações sociais e culturais intrínsecas à modernidade europeia que se consolida e se irradia no século XIX.

Já se tornou comum (mas continua ainda útil), ao se falar de modernidade, evocar as palavras de Marx e Engels

É o permanente revolucionar da produção, o abalar ininterrupto de todas as condições sociais, a incerteza e o movimento eternos [...] Todas as relações fixas e congeladas, com seu cortejo de vetustas representações e concepções, são dissolvidas, todas as relações recém-formadas envelhecem antes de poderem ossificar-se. Tudo que é sólido se desmancha no ar. (Marx; Engels, 1982, p.67)

\section{O contexto em que emergem os discursos em torno da nação} coincide com essa percepção da modernidade marcada pela ace-

"vontade, autodeterminação e capacidade de atuar sobre a natureza e outros indivíduos" (Cerri, 2002, p.198). Em outra instância, a reificação faz a nação funcionar como semióforo, como aponta Marilena Chaui (2000). Carregando uma significação com consequências presentes e futuras para os homens e dotada de grande força simbólica e fecundidade, a nação, como semióforo, torna-se a matriz do poder político, "objeto do culto integrador da sociedade una e indivisa" (idem, p.14).

5 Autores contemporâneos traçam caminho semelhante à constatação de Marx e Engels. Marshall Berman afirmaria que ser moderno é "experimentar a existência pessoal e social como um torvelinho, ver o mundo e a si próprio em perpétua desintegração e renovação, agitação e angústia, ambiguidade e contradição: é ser parte de um universo em que tudo o que é sólido desmancha no ar" (Berman, 1986, p.328). Na mesma direção, vai a análise de Bauman: "a modernidade é o que é - uma obsessiva marcha adiante - não porque sempre queira mais, mas porque nunca consegue o bastante; não porque se torne mais ambiciosa e aventureira, mas porque suas aventuras são mais amargas e suas ambições frustradas. A marcha deve seguir adiante porque qualquer ponto de chegada não passa de uma estação temporária” (Bauman, 1999, p.18). Embora as constatações apontem para a constituição de uma (des)ordem pós-tradicional, com o ritmo de mudanças gerando ambiguidade e angústia, é preciso destacar que no trecho citado, Marx e Engels estão elogiando as mudanças promovidas pelos revolucionários burgueses. 
leração das mudanças, por transformações estruturais intensas, dentre elas a industrialização, a urbanização, a secularização e as lutas pela democracia constitucional, cujos efeitos se percebem, também, no desenraizamento das culturas e valores tradicionais. Os modos de vida convencionais e as tradições passam a ser postos em xeque. O filósofo social inglês Anthony Giddens considera que "as instituições modernas diferem de todas as formas anteriores de ordem social, quanto a seu dinamismo, ao grau em que interferem com hábitos e costumes tradicionais, e ao seu impacto global" (Giddens, 2002, p.9). E ele vai além:

Os modos de vida produzidos pela modernidade nos desvencilharam de todos os tipos tradicionais de ordem social, de uma maneira que não tem precedentes. [...] as transformações envolvidas na modernidade são mais profundas que a maioria dos tipos de mudança características dos períodos precedentes. [...] elas vieram a alterar algumas das mais íntimas e pessoais características de nossa existência cotidiana. (Giddens, 1991, p.14)

Todas essas constatações a respeito da modernidade, em um primeiro momento, parecem produzir um contraste excessivo com a ideia de nação baseada nas "origens, na continuidade, na tradição, na intemporalidade" (Hall, 2006, p.53). ${ }^{6}$ Contudo, um olhar mais atento perceberá que a nação, como discurso identitário e organização sociopolítica que se impõe gradativamente no século XIX, está imbricada com o desenraizamento cultural e a aceleração das transformações sociais.

Bauman nos mostra que essa mesma modernidade, vivida como redemoinho, projetava, ao menos como desejo, uma nova

6 O contraste aumenta ainda mais se pensarmos em reflexões como a de Kumar: "a modernidade sente que o passado não tem lições para ela; seu impulso é constantemente em direção ao futuro” (Kumar, 1996, p.473). 
ordem. "Os sólidos podem ser derretidos, mas o são para moldar novos sólidos” (Bauman, 2008, p.182). Embora não coadune sempre com os padrões de racionalidade e lógica ideados pela modernidade, o discurso da nacionalidade foi capaz de dar conta de uma perspectiva de futuro e de transformação e, ao mesmo tempo, eliminar, ao menos no nível simbólico ou imaginário, o caos e a desordem. Assim, a nação torna-se um projeto de estabilidade diante do que se desmancha no ar. Através dela as transformações podem ser explicadas e adquirir sentido.

A ideia de nação, de identidade nacional, e seu desenvolvimento como força política, tem sido debatida há muito tempo pelas ciências sociais. Nem todos os autores endossariam integralmente o diagnóstico apontado acima. Vale a pena examinarmos alguns destes posicionamentos, suas aproximações e divergências para daí extrairmos mais algumas possibilidades interpretativas que nos ajudarão nesta abordagem sobre os dilemas da identidade nacional.

Ainda no século XIX, é do historiador francês Ernest Renan um dos mais célebres textos sobre a existência da nação e seus fundamentos. Em sua conferência proferida na Sorbonne, em 1882, intitulada "Que é uma nação?", desenvolveu um raciocínio em defesa do princípio nacional, mas, surpreendentemente, se levarmos em conta a época, contrariando os principais argumentos utilizados neste período com relação à base formadora das nações. Para ele, a nação não seria fruto da raça, da religião, da língua, da geografia, nem das necessidades militares. ${ }^{7}$ Ela seria procedente, isto $\mathrm{sim}$, de uma vontade comum no presente,

7 Angela Alonso e Samuel Titan Jr. alertam para não nos empolgarmos com o "sabor antropológico" dos argumentos de Renan construídos já em tempos de oposição entre França e Alemanha. Em outros escritos, o historiador francês utiliza com veemência o conceito de raça para explicar a situação das colônias europeias. Sua concepção de nação valia, portanto, apenas para o seu continente (Alonso; Titan Jr., 1997). 
do esquecimento da violência originária de todas as nações e da valorização de uma glória comum, herança do passado. Mais do que um consenso, base de um contrato social moderno, esta última característica, para o autor, faz da nação "uma alma, um princípio espiritual" (Renan, 1997, p.173).

Já na ciência social clássica o tema da nação é abordado, dentre outros, por Marcel Mauss e Max Weber. Na busca por classificar as formas políticas da vida social, ambos vão entender que o Estado-nação representaria o ápice da integração e de uma solidariedade social orgânica. É justamente esse sentimento de coletividade, consubstancializado na instituição do Estado pela nação, que marcaria uma passagem evolutiva na organização política. À maneira de Renan, Mauss entende a nação como fruto de um consenso, de uma vontade geral e reconhece que é a nação estabelecida quem cria a ideia de unidade racial e, também, muitas de suas tradições, selecionadas entre práticas culturais diversas. A concepção de nação, para este autor, assemelha-se aos discursos sociais nacionalistas, que se estabeleceram a partir do século XIX, ressaltando a unidade moral dos indivíduos que a compõem. A nação é, assim, um fato social estabelecido pela vontade, mas também por uma evolução natural que a faz a continuidade da solidariedade orgânica dos clãs primitivos. O mérito da identidade nacional para Mauss estaria em construir uma resposta à tendência à desintegração provocada pela modernidade, abolindo as divisões internas da sociedade e ampliando largamente a solidariedade e a homogeneidade do clã primitivo. $^{8}$

8 Portanto, a nação, para Mauss, é dotada de um conteúdo altamente positivo. Conquanto reconheça que certa presunção natural e chauvinismo sejam intrínsecos à imaginação nacional, o nacionalismo exacerbado, com a xenofobia e a defesa do tradicionalismo, seria, para o antropólogo francês, uma patologia da identidade nacional que deveria ser extirpada como um abscesso. 
O discurso de Renan fez escola e a argumentação de Weber começa por negar a centralidade da religião, da língua e dos laços consanguíneos para o estabelecimento das nações. Contudo, ainda que levando em conta o papel dos intelectuais e da imprensa (livros, periódicos e, acima de tudo, os jornais) na difusão do princípio nacional, Weber entende a nação como uma comunidade que normalmente tende a produzir um Estado próprio. Logo, não será fruto apenas do desencantamento do mundo gerado pela modernidade, mas da necessidade de coesão inerente a qualquer comunidade política. Não obstante reconheça que a homogeneidade nacional seja indefinida e baseada em sentimentos de solidariedade bastante heterogêneos, para Weber há um sentimento de nacionalidade anterior à institucionalização da nação política.

A partir da década de 1970, passa a predominar, no seio da produção intelectual, a rejeição a concepções essencialistas da identidade nacional. Dentro de uma posição construtivista, percebendo que as categorias sociais são culturalmente construídas, autores se dispõem a encarar a nação como artefato cultural, portanto, como representação (Cf. Rovisco, 2003). ${ }^{9}$ Estará em debate a ação do Estado moderno e do nacionalismo, como movimento político, na formação da identidade nacional. A homogeneidade cultural da nação poderia ser induzida politicamente. Em que pesem sua relação com outras formas de identidade anteriores,

9 Posições do tipo essencialista ainda circulam, inclusive na produção intelectual. A obra de Josep Llobera, The God of Modernity (publicada originalmente em 1994), por exemplo, apropriando-se de historiadores como Marc Bloch e Huizinga e de sociólogos como Weber, procura entender a nação como um valor cultural, como uma comunidade enraizada na totalidade da população e com uma larga história anterior. Para este autor, ao final da época medieval, a identidade nacional estava determinada: "es cierto que el nacionalismo moderno sólo apareció como una secuela de la Revolución Francesa, pero la identidad nacional es un fenómeno de la longue durée" (Llobera, 1996, p.13). Llobera, no entanto, prudentemente, se abstém de generalizar suas conclusões para outros lugares fora da Europa ocidental. 
as identidades nacionais seriam um fenômeno recente, forjado por uma série de interesses políticos e econômicos.

Ernest Gellner talvez mantenha a posição mais veemente dessa vertente. Para ele, as nações são construídas por uma ação da elite que assume o Estado no século XIX. Trata-se de uma tentativa de amalgamar a unidade política a uma unidade cultural. É a ação centralizada do Estado que proporciona a homogeneização de uma identidade nacional, através da educação pública e da implantação de um sistema de comunicação de massas capazes de unificar a língua, difundir certo padrão de uma cultura de elite, mitos históricos e "'invenções históricas' arbitrárias" (Gellner, 1993, p.89).

Ainda nesse viés interpretativo, mas em busca de olhares mais amplos quanto às ideias de manipulação e invenção, as análises de Benedict Anderson, Eric Hobsbawm e Anthony Smith são as que acabam por nortear a maior parte das interpretações contemporâneas sobre a identidade nacional.

Os posicionamentos do historiador inglês Eric Hobsbawm em Nações e nacionalismos desde 1780 são os mais próximos aos de Gellner. A exemplo deste último, Hobsbawm (1991, p.19) salienta "o elemento do artefato, da invenção e da engenharia social que entra na formação das nações. [...]. As nações não formam os estados e os nacionalismos, mas sim o oposto”.

Numa abordagem semelhante, na forma, à de Renan, Hobsbawm vai, paulatinamente, refutando as teses que tomam a língua, a etnicidade e a religião como elementos pré-formadores da nação. Para ele, a criação de um Estado administrativo moderno, mobilizador e influenciador dos cidadãos, e a democratização da política são os fatores essenciais na formação das nações modernas. "Os Estados iriam usar a maquinaria de comunicação, crescentemente poderosa, junto a seus habitantes - sobretudo, as escolas primárias - para difundir a imagem e a herança da ‘nação' e inculcar adesão a ela [...]” (Hobsbawm, 1990, p.112). 
Por outro lado, Hobsbawm tenta se distanciar da concepção de "modernização pelo alto" defendida por Gellner. O nacionalismo se constrói por ações e reações que também podem vir da mobilização popular e, em muitos casos, haveria laços protonacionais, sentimentos de vínculo coletivo pré-existentes, passíveis de serem operados na escala macropolítica pelos Estados ou movimentos nacionalistas. ${ }^{10}$ É nesta perspectiva que Hobsbawm acaba por caracterizar as nações como:

fenômenos duais, construídos essencialmente pelo alto, mas que, no entanto, não podem ser compreendidas sem ser analisadas de baixo, ou seja, em termos das suposições, esperanças, necessidades, aspirações e interesses das pessoas comuns, as quais não são necessariamente nacionais e menos ainda nacionalistas. (Hobsbawm, 1991, p.20)

Referência ainda mais presente nos estudos contemporâneos a respeito da nação e do nacionalismo será a obra Comunidades imaginadas, de Benedict Anderson. Nela, o autor percebe a nação como fruto mais ou menos espontâneo do " "cruzamento' complexo de diferentes forças históricas” (Anderson, 2008, p.30), que se engendram a partir do final do século XVIII, e não apenas como objeto de uma manipulação vinda de um centro controlador.

Uma das chaves principais para entender esse fenômeno estaria no desenvolvimento da imprensa como mercadoria - o que ele chama de capitalismo editorial. A busca por novos públicos leitores proporcionou o desenvolvimento de línguas impressas (com uma maior fixidez do que as orais, dando impressão de

10 Inclusive com a possibilidade de "preencher o vazio emocional causado pelo declínio ou desintegração, ou a inexistência de redes de relações ou comunidades humanas 'reais'” (Hobsbawm, 1990, p.63). 
permanência no tempo) e campos unificados de intercâmbio e comunicação.

A nação seria, então, uma "comunidade imaginada" - como o são todas as sociedades, "necessariamente, uma estrutura social e um artifício de imaginação” (Balakrishnan, 2000, p.216) - e alicerçada sobre as transformações geradas por novas relações sociais de produção que despontam com a modernidade. Entretanto, para Anderson, a partir do momento em que o modelo está estabelecido, ele é plausível de ser imitado, com diversos graus de consciência, inclusive como objeto de manipulação intencional. Ao se referir aos novos Estados-nação surgidos da dissolução dos impérios europeus, o autor afirma que:

[...] nas políticas de "construção da nação" dos novos Estados, vemos [...] um autêntico entusiasmo nacionalista popular ao lado de uma instilação sistemática, e até maquiavélica da ideologia nacionalista através dos meios de comunicação de massa, do sistema educacional, das regulamentações administrativas, e assim por diante. (Anderson, 2008, p.164)

Na maior parte de sua análise, contudo, Anderson faz um esforço para mostrar que as nações são portadoras de uma legitimidade muito forte, despertando um apego emocional profundo. A forma de funcionamento do nacionalismo estaria mais próxima do fenômeno religioso do que das ideologias políticas. Propõe, neste caminho, o "entendimento do nacionalismo alinhando-o não a ideologias políticas conscientemente adotadas, mas aos grandes sistemas culturais que o precederam, e a partir dos quais ele surgiu, inclusive para combatê-los" (Anderson, 2008, p.39). As nações seriam, portanto, imaginadas dentro dos limites e ideais vividos a cada momento histórico por comunidades específicas. Como diz Lilia Moritz Schwarcz no prefácio à edição brasileira do livro de Anderson: "Não se imagina no vazio e com 
base em nada. Os símbolos são eficientes quando se afirmam no interior de uma lógica comunitária afetiva de sentidos [...]" (Schwarcz, 2008, p.16).

Constatando a ubiquidade da nação no mundo contemporâneo, o teórico inglês Anthony Smith, por sua vez, insiste um pouco mais do que seus pares nas origens pré-modernas desse fenômeno. A chave para interpretá-lo estaria nas raízes étnicas comuns, legatárias de uma história de longo prazo.

[...] historicamente, as primeiras nações foram [...] formadas com base em núcleos étnicos pré-modernos e, por serem poderosas e culturalmente influentes, forneceram modelos para casos subsequentes de formação de nações em muitas partes do globo.

[...] o modelo étnico se tornou cada vez mais popular e corrente [...] por assentar tão folgadamente sobre o tipo de comunidade "demótica" pré-moderna que sobreviveu até a era moderna em tantas partes do mundo. Por outras palavras, o modelo étnico foi sociologicamente fértil. (Smith, 1997, p.60)

A ênfase na interpretação da nação como uma espécie de depositário histórico de longo prazo faz Smith diminuir o peso da ideia de fabricação ou invenção. "A invenção deve ser entendida em seu outro sentido: é uma recombinação inédita de elementos já existentes" (Smith, 2000, p.202). A nação trata-se, então, de um fenômeno cultural que ganha uso político e ideológico.

Contudo, Smith não se distancia tanto dos demais autores tratados quanto, num primeiro momento, poderia parecer. Ele reconhece que as nações modernas, com cidadãos massificados, só puderam emergir na era do industrialismo e da democracia. A linguagem e o simbolismo nacionalistas começam como um fenômeno de elite, no qual os intelectuais desempenham um papel preponderante. Um vigoroso programa de socialização política, realizado através dos sistemas de comunicação e de educação 
pública de massas foi essencial para o Estado configurar a nação moderna em conjunto com (e no contexto de) outros processos. Assim é que a "nova concepção da nação foi criada para servir como estrutura espaço-temporal de ordenação do caos e para dar significado ao universo, ao prender aspirações e sentimentos de massa pré-modernos a laços locais e familiares" (Smith, 2000, p.103).

As visões sobre a nação apresentadas até aqui carregam em si divergências explícitas, mas também certa complementaridade. É possível, assim, destacarmos, a partir das convergências, uma leitura geral sobre as possibilidades interpretativas contemporâneas a respeito da nação e das identidades nacionais como sistemas simbólicos atribuidores de identidades sociais.

Como diz José Murilo de Carvalho (2003, p.397), "às vezes, o Estado cria a Nação, às vezes é o oposto que se dá, às vezes criam-se os dois mutuamente”. Para além das dúvidas a respeito da precedência, importa-nos perceber que a constituição do binômio "Estado-nação" indica que na modernidade houve uma tendência para tornar "a cultura e a esfera política congruentes" (cf. Hall, 2006). A unificação política, concomitante à unificação cultural, faz, para a maior parte dos casos, as exigências de lealdade ao Estado e à nação coincidirem. Isso explica, em parte, a permanência das representações da identidade nacional: o Estado-nação tornou-se o espaço (físico e simbólico) privilegiado da ação política e é dentro deste espaço que ocorrem a maior parte das interações sociais. Como mostra Hobsbawm (1991), a presença do carteiro, do policial, do professor, da estrada de ferro, dos soldados, dos censos periódicos etc. indica um aumento significativo de intervenções do Estado na vida das famílias ao longo do século XIX. ${ }^{11}$

11 A referência temporal do diagnóstico é específica para parte da Europa e para os EUA. 
No mesmo caminho, embora possa se observar elementos anteriores à modernidade capitalista na formação das identidades nacionais, é preciso considerar que a difusão dos ideais de nação e do nacionalismo é legatária do trabalho e da adesão essencial de uma categoria a que Antony Smith chama de intelectuais-pedagogos. Em sua obra, Anderson (2008) salienta o papel desempenhado pela cultura escrita e pela imprensa na construção, narração e difusão do sentido da nação. É justamente entre essa parte da camada letrada, capaz de - e disposta a - produzir representações escritas (ou iconográficas), que se encontra certo sentido de missão (autoatribuído) para instituir, despertar ou resgatar a identidade nacional. Em que pese a necessidade da existência de precondições objetivas para a eficácia das representações construídas, percebe-se que foram os intelectuais que propuseram e elaboraram os conceitos e a linguagem da nação e do nacionalismo (Smith, 1997, p.119) ao menos em sua versão mais visível. A promessa nacionalista de posteridade atraiu poetas, músicos, pintores, escultores, romancistas, historiadores, arqueólogos, dramaturgos, filólogos, lexicógrafos, antropólogos e folcloristas (Smith, 1997, p.119) que procederam à "escavação" intensa à procura de uma identidade e de valores genuinamente nacionais, projetados a partir de um passado comum.

É dessa maneira - através de reconstruções e bricolagens que os discursos identitários que fundamentam a nação, estruturam-se sobre a "recombinação de elementos pré-existentes" (Cf. Smith, 2000, p.207). Mesmo considerando a possibilidade de ação direta e intencional do Estado através dos meios de comunicação, ${ }^{12}$ nos quais também podem ser incluídos a escola e os livros didáticos; é preciso ponderar que esta ação se utiliza de va-

12 Ressalvando que o nacionalismo não é necessariamente um fenômeno das elites, não raro refletindo até mesmo uma reação contra as elites mundiais (sobre o assunto ver Castells, 1996). 
lores enraizados com certo respaldo social. Toda representação de identidades necessita dessa ressonância: "é nas cosmologias pré-existentes em concepções arraigadas que se encontram o material suficiente, o repositório partilhado para a conformação de modelos identitários, que fazem sentido para além da manipulação mais imediata" (Schwarcz, 2001, p.14). A seleção, contudo, dos aspectos da cultura a serem ressaltados é feita, muitas vezes, com a atribuição de outros valores a estes elementos, buscando-se uma ressignificação consonante com objetivos de cada grupo em cada período. O fim almejado será sempre a conquista da adesão afetiva, canalizando interesses, emoções, aspirações e medos coletivos.

De toda forma, é possível perceber que nos discursos a respeito da nação, os componentes culturais, políticos, afetivos e racionais estão entrelaçados. Essa constatação significa não endossar a dicotomia entre o modelo étnico e cívico oriental uma superfamília imaginária, concepção orgânica e mística - e o ocidental - racional e associativo (Cf. Kohn, apud Smith, 1997) de nação. Rita Ribeiro mostra que para a compreensão do fenômeno é necessária a inter-relação entre os dois modelos de nação cultural-étnico-orgânico e cívico-político-territorial:

[...] mesmo as nações políticas têm necessidade de um grau mínimo de coesão cultural, sacralizam os seus símbolos e deitam mão da força do Estado para homogeneizarem a língua e o sistema educativo nacional, assim como as nações étnicas, cujas fronteiras estão idealmente no sangue, na linhagem e na cultura, fizeram e fazem quase sempre apelo à formação de um Estado soberano, senão independente. (Ribeiro, 2004, p.90)

Bauman, em suas análises, também procurou diminuir o peso da oposição entre a possibilidade de pertencer a uma nação por adscrição primordial ou por escolha. O fato é que cultura e polí- 
tica, etnicismo e civismo se amalgamam na tendência à homogeneização que as representações de identidade nacional carregam consigo. É dentro dos ideais românticos que a nação passa "a ser concebida como uma entidade emotiva, símbolo da singularidade, à qual todos os homens deveriam se integrar" (Oliveira, 1990, p.43). O "nós" coletivo, a "camaradagem horizontal" (Anderson, 2008), a neutralização das diferenças e o ressaltar das semelhanças fazem parte da constituição de certa "utopia das desigualdades harmônicas" (Marchi, 1994), ${ }^{13}$ presente nos projetos nacionais dos vários modelos difundidos pelo globo.

Toda identidade, no nível das representações, tem sempre que estar ligada a uma continuidade no tempo, por isso a emergência da História como disciplina acadêmica e escolar no século XIX é aspecto central para a consolidação política e simbólica dos Estados-nação. A escrita da história é mais que um espaço privilegiado, é protagonista na construção da lógica e da legitimação das narrativas da nação. José Carlos Reis chega a afirmar que a crítica historiográfica é a própria “vida do espírito” de uma nação. A narrativa histórica acaba se constituindo no principal meio capaz de promover a "transformação secular da fatalidade em continuidade, da contingência em significado" (Anderson, 2008, p.19). Trata-se da busca de um passado utilizável cuja construção evidencia também a ligação entre o historicismo e o Romantismo no século XIX. ${ }^{14}$

13 Tomo o termo emprestado de Euclides Marchi que, por sua vez, o utiliza para explicar o projeto de mundo presente na Rerum Novarum, base da doutrina social católica.

14 Além de certa nostalgia pelo passado, no qual se encontraria a origem e a essência do espírito nacional, boa parte da historiografia do século XIX vai compartilhar com o Romantismo da forma do romance moderno, compondo um bildungsroman da nação. "E é o romance, um gênero literário tão jovem quanto a ideia de nação, que servirá, ao mesmo tempo, de modelo narrativo para as primeiras elaborações eruditas de escrita nacional e de vetor de difusão de uma nova visão do passado" (Thiesse, 2002, p.12). 
Diferentemente dos princípios universalizantes iluministas, o discurso histórico nacional valorizará a especificidade, aquilo que é irredutível, compondo, concomitantemente, sentido de coerência ao longo do tempo. Um dos seus objetivos é "colocar em evidência a continuidade e a unidade da nação como ser coletivo através dos séculos, apesar de todas as opressões, de todos os infortúnios, de todas as traições” (Thiesse, 2002, p.12). A nação é representada, então, como algo que sempre existiu. As representações construídas produzem ou reforçam a crença subjetiva na ascendência étnica comum (Cf. Weber, 1991) e na existência de um território de origem e destino. Na projeção temporal, a nação surge como um devir deste território e deste povo original.

É com auxílio do discurso histórico que as principais representações da nação se consolidarão. Na construção discursiva da nação, neste espelho em que se projeta sua unidade orgânica, há representações que, por sua constante reiteração, acabam tendo um peso maior, instalando-se com certa profundidade no imaginário social. São representações fundadoras em um duplo sentido, expresso em duas formas de discurso complementares: a) são fundadoras no sentido de serem as primeiras representações que o país recebeu, reforçadas (especialmente - mas não apenas no caso das imagens "positivas") no momento do empenho na construção da identidade nacional dentro dos ideais românticos; b) são fundadoras as representações que evocam um evento de fundação, no qual se definiriam as características básicas da nação a se perpetuar no tempo. Essas representações se enraízam de tal forma que as construções discursivas as quais intentam superá-las têm forçosamente que negociar sentidos com elas.

Uma produção teórica consistente tem dado destaque à força dessas representações. Marilena Chaui as toma por mito fundador, no sentido antropológico em que essas narrativas são a "solução imaginária para tensões, conflitos e contradições que não encontram caminhos para serem resolvidos no nível da rea- 
lidade" (Chaui, 2000, p.9). Ao percebê-lo como produtor e produto de uma consciência, ainda que difusa, de pertencimento, a autora considera que o mito fundador "oferece um repertório inicial de representações da realidade e, em cada momento da formação histórica, esses elementos são reorganizados" (Chaui, 2000, p.10). ${ }^{15}$

Em outro caminho teórico-metodológico, mas não menos instigante, Eni P. Orlandi analisa essas representações como discursos fundadores, aqueles que funcionam como referência básica no imaginário constitutivo de um país. Para essa pesquisadora, estes enunciados "vão nos inventando um passado inequívoco e empurrando um futuro pela frente [...] nos dão a sensação de estarmos dentro de uma história de um mundo conhecido" (Orlandi, 2001, p.12). São as imagens enunciativas emanadas dos discursos fundadores que transfiguram o sem-sentido em sentido, operando um silenciamento, ainda que temporário, de outros sentidos excluídos. Nas palavras da autora, o discurso fundador

instala as condições de formação de outros, filiando-se à sua própria possibilidade, instituindo em seu conjunto um complexo de formações discursivas, uma região de sentidos, um sítio de significância que configura um processo de identificação para uma cultura, uma nação, uma nacionalidade. (idem, p.24)

Sejam tratadas como mitos, discursos ou representações, as narrativas da nação são constantemente presentificadas - mas também ressignificadas - na busca de coesão social. Este processo de retroalimentação faz com que o passado não seja assim "tão

15 Chaui (2000, p.9) investe inclusive na acepção psicanalítica do mito, tomando-o como "impulso à repetição de algo imaginário que cria um bloqueio à percepção da realidade e impede lidar com ela”. 
passado", pois a própria nação torna-se um sistema de representação cultural ligado a interesses dos grupos sociais, nos jogos, confrontos e conciliações de poder na sociedade.

É assim que as representações da nação são vivenciadas concretamente pelos agentes sociais, conforme os grupos de que fazem parte. Os atores sociais tomam essas representações como reais, incorporando-as como referentes para suas interpretações. As representações da nação, presentes nos discursos das mais variadas tendências políticas, atuam articulando sentidos: servem de fonte legitimadora e acabam por orientar estratégias, projetos e outras práticas sociais.

\section{À guisa de epílogo}

No final do seu livro sobre nações e nacionalismos (escrito nos finais dos anos 1980), Hobsbawm constatava (a partir de uma metáfora hegeliana) que a coruja de Minerva - que traz sabedoria, mas voa no crepúsculo - estava agora rondando as nações e o nacionalismo. No auge dos discursos sobre a globalização, nos finais da década de 1990, analistas também anunciavam a crise do Estado e da identidade nacional como instrumento capaz de dar sentido ao mundo contemporâneo. No mesmo caminho, pesquisadores sobre as identidades apontam, ainda hoje, uma menor presença da identidade nacional para a construção dos sujeitos contemporâneos.

Em que pesem a relevância dessas análises que levam em conta a transnacionalidade das relações econômicas e a possibilidade de comunicação em rede, outros autores, contemporaneamente, têm ressaltado que se vive em um mundo onde as questões e desafios colocados pela modernidade ainda não foram plenamente respondidos. Constata-se, então, a permanência da identidade nacional como forma de identificação coletiva, convi- 
vendo, sem se apagar, com outras formas de identidade devido à sua estruturação "mais híbrida na articulação entre diferenças e identidades culturais - gênero, raça ou classe - do que uma estruturação hierárquica ou binária do antagonismo social é capaz de representar" (Bhabha, 2001, p.534).

Embora, como vimos anteriormente, novas fontes de identidade despontem na contemporaneidade, representações das identidades nacionais são constantemente reiteradas no presente. De fato, essas representações continuam circulando na produção acadêmica, na mídia, na memória, na tradição, na escola. Essa possível ubiquidade se revela em formas que chegam a "impregnar de tal maneira nossa vida coletiva que resultam invisíveis de tão óbvias" (Rosa; Bellelli; Bakhurst, 2008, p.179). Para Smith, a persistência dos discursos de identidade nacional estaria ligada à multidimensionalidade da concepção de nação, característica que a teria transformado numa força "flexível e persistente da vida e da política moderna” (Smith, 2000, p.30), permitindo que se associasse eficazmente a outras forças e movimentos modernos, sem perder os seus elementos centrais. Anderson (2008) já alertava que as nações são portadoras de uma legitimidade muito forte, despertando um apego emocional profundo. A complexidade e a resistência do fenômeno da identidade nacional podem ajudar a explicar, inclusive, a permanência de certa "visão romântica de nação - espaço homogêneo do território, tempo homogêneo da história nacional, cultura homogênea em toda a população” (Novaes, 2003, p.12).

$\mathrm{Na}$ atualidade, há, portanto, que se considerar uma longa trajetória de discursos de identidade nacional, veiculados no decorrer do tempo, que funcionam como uma história incorporada, ${ }^{16}$

16 Ao abordar as relações entre a história reificada e a história incorporada, Bourdieu amplia suas observações sobre a origem social das representações, ou melhor, das práticas culturais. Para ele, há uma história em estado objetivado, que se acumulou ao longo do tempo nos objetos, ferramentas, instituições. Há 
a qual não se pode desprezar. Como se refere a pesquisadora Rita Ribeiro (2004, p.11), “depois do nacionalismo, nada pode ser pensado como se ele não tivesse existido e, como tal, não é simplesmente possível passar por cima das nações”. A eficácia discursiva, simbólica e política de novas representações identitárias dependerá do diálogo estabelecido com elementos de permanência de longo prazo, dentro das condições e limites dados por conjunturas específicas. Alberto Rosa, Guglielmo Bellelli e David Bakhurst, ajudam-nos a pensar um pouco mais sobre as permanências e reiterações das representações identitárias nacionais, seus discursos e suas possibilidades de transformação:

no resulta sorprendente que sentimientos de identidad y modos de ser colectivos tengan una gran capacidad de permanencia, a pesar de cambios culturales, sociales y políticos bastante radicales. El universo simbólico, los mitos del pasado colectivo, la propia idea del "nosotros" colectivo resultan extremadamente resistentes a la substitución de unos significantes por otros, aunque eso no quiere decir que el cambio sea imposible, pues la Historia nos muestra cómo etnias y naciones se crean, se transforman o llegan a disolverse. Lo que sí parece claro es que no resulta fácil imponer cambios culturales, ni alterar las ideas constitutivas que las personas de una comunidad tengan sobre su propio ser, aunque se utilicen métodos muy brutales. La modificación de las señas de identidad no sólo pasa por el cambio de una simbología sino, también, por el de los mismos significados que se transportan, que deben ser convencionalizados en la comunidad que los utiliza, y entrar en

também uma história que se tornou habitus, incorporada, inscrita nos corpos, noção que se aproxima à ideia de segunda natureza de Norbert Elias. Essa permanência (o passado continua vivo) restringe o universo dos possíveis. "Podemos compreender que o ser social é aquilo que foi; mas também que aquilo que uma vez foi ficou para sempre inscrito não só na história, o que é óbvio, mas também no ser social, nas coisas e nos corpos” (Bourdieu, 1989, p.100). 
la dinámica afectiva de los elementos de la cultura de ese grupo. (Rosa; Bellelli; Bakhurst, 2008, p.190)

Assim, ainda que a problemática das identidades tenha retornado, com maior intensidade, à ordem do dia, nos finais do século XX e na primeira década do século XXI e as identidades sejam, visivelmente, cada vez mais, conscientemente mobilizadas no campo político, envolvendo disputas materiais e simbólicas, pode-se perceber que a diversidade identitária e a identidade nacional não conflitam de maneira tão excludente, na maior parte dos Estados estabelecidos, como em um primeiro momento parecia acontecer. Em muitos casos não é a identidade nacional que é posta em xeque, mas sua representação. Os embates entre os diferentes grupos dão-se pelos sentidos - por uma revisão da gramática - que envolvem esse grande símbolo identitário que funciona como semióforo para as sociedades modernas.

Se, como constatamos anteriormente, as experiências objetivas e subjetivas dos seres humanos se constroem em interação com representações a respeito de quem são e quem podem ser, é forçoso constatar que muito dos dilemas contemporâneos a respeito de alteridade, autoestima, eticidade e moralidade dialogam diretamente com as representações identitárias nacionais. Por tudo isso, pensar por dentro, entre e em torno da nação e suas representações, no passado e no presente, pode ainda ser um recurso intelectual instigante, senão fundamental. 


\title{
A libertação de Cam: discriminar para igualar. Sobre a questão racial brasileira ${ }^{1}$
}

\author{
Maria Bernardete Ramos Flores ${ }^{2}$ \\ Sabrina Fernandes Melo $^{3}$
}

\begin{abstract}
A obra pictórica Redenção do Cam (1895) de Modesto Brocos y Gomes já serviu a diversos cientistas sociais, antropólogos, historiadores, para ilustrar a ideologia do branqueamento do Brasil. O quadro retrata uma avó negra, a filha mulata, o genro e o neto brancos. De fato, trata-se de uma representação acabada da política de miscigenação apregoada para fazer desaparecer o negro brasileiro, sem destruir Cam, o filho amaldiçoado de Noé (Gênesis 9: 18-19), e sem desaguar na violência que marcou o fim da escravidão nos Estados Unidos. Quando o diretor do Museu Nacional, João Batista de Lacerda, foi participar do Congresso Universal das Raças (1911), em Londres, levou consigo o quadro de Brocos y Gomes para demonstrar sua tese Sur les
\end{abstract}

1 Este artigo contou com o apoio em pesquisa dos seguintes alunos de graduação: Daniel Dalla Zen e Victor Wolfgang Kegel Amal (Pibic/CNPq); Poliana Santana, Carolina Bayer e Fernanda Emanuella Maccari (Bolsa Permanência).

2 Doutora em História, professora titular em História Cultural (UFSC), pesquisadora do $\mathrm{CNPq}(\mathrm{PQ}-1 \mathrm{~B})$ e autora do livro Tecnologia e estética do racismo: ciência e arte na política da beleza (2007). E-mail: mbernaramos@gmail.com.

3 Doutoranda em História pela Universidade Federal de Santa Catarina (UFSC), com a tese: Imagens coloniais em tempos modernistas: a propósito de Robert C. Smith e sua metodologia como historiador da arte. 
métis au Brèsil [Sobre os mestiços do Brasil]. Nesta, impressa, há uma reprodução de Redenção do Cam, acompanhada da seguinte legenda: "O negro passando ao branco, na terceira geração, por efeito do cruzamento de raças” (Seyfeth, 2011, p.62-67).

Embora nada conste na Bíblia sobre a cor de Cam e de seus descendentes, segundo David Goldemberg (2003 apud Oliva, 2007, p.48), os efeitos interpretativos da "maldição lançada a Cam" tiveram desdobramentos na imaginação ocidental, para justificar a escravidão de negros africanos, os quais seriam descendentes de Cam. No século XIX, em resposta ao movimento abolicionista nos Estados Unidos, os brancos racistas lançaram mão do relato bíblico. No Brasil, a maldição de Cam serviu de justificativa para a escravização de índios e negros. A escravização e o extermínio seriam o preço a pagar pela redenção do pecado cometido por Cam, ter visto seu pai nu, quando este dormia embriagado. A escravidão seria a sina da população negra africana e seus descendentes, visando a regeneração e purificação deste pecado. "O Mito de Cam procurou explicar de certa forma a escravidão dos africanos, mas na verdade, justificou o elo entre a escravidão e 'cor' da pele" (Carvalho Junior, 2011, p.4).

Evocaremos aqui a imagem de Cam não para redimi-lo da "inventada maldição", mas como alegoria do movimento (político, cultural e social) empreendido no Brasil nas últimas décadas, especialmente depois dos anos de 1980, contra o preconceito e a desigualdade racial, em prol da população negra brasileira. ${ }^{4}$ Com o fim da crença no determinismo biológico racial, veio o reconhecimento da existência das raças sociológicas; com o fim da crença na democracia racial, veio o reconhecimento da existência do preconceito racial; com o fim da

4 Houve igualmente diversas políticas em prol da população indígena. Mas como há uma especificidade bastante grande, que singulariza tanto a história deste grupo quanto suas reivindicações atuais, não temos espaço, no contexto deste artigo, para abordá-las de forma consistente. 
crença na superioridade da civilização branca, europeia, cristã, veio o reconhecimento dos valores multiculturais; com o fim do padrão único de beleza, veio a valorização da beleza negra e, em consequência, a melhoria da autoestima negra, e vimos uma série de acontecimentos capazes de instituir esquemas de "discriminação positiva” em favor dos grupos raciais historicamente "discriminados" de forma negativa. Em contrapartida ao racismo, ao preconceito racial e à marginalização, as cotas universitárias criaram uma universidade mais colorida, mais negra, menos branca; o Movimento Negro e a afirmação da negritude fez surgir uma nova etnosemântica: em vez de "preto", falamos "negro", em vez de "etnia", falamos "raça".

Para conclamar a libertação de Cam, partimos da sugestão de David Theo de Goldberg (apud Azevedo, 2004, p.27):

embora a raça tenha tendido historicamente a definir condições de opressão, ela pode, sob uma interpretação culturalista [...] ser o lugar de um contra-ataque, um solo ou campo para deslanchar projetos de libertação ou a partir do qual se poderia expandir a(s) liberdade(s) e abrir espaços emancipatórios.

Usaremos aqui a designação raça, sem aspas e sem ressalvas, para tomar o significado corrente: seu uso político, hoje, designa um signo para reconhecer a desigualdade social e cultural, e que possibilita dar visualidade ao "outro", instituído historicamente e aceito socialmente. Conforme Edward Telles (2003, p.38):

O uso do termo raça fortalece distinções sociais que não possuem qualquer valor biológico, mas a raça continua a ser imensamente importante nas interações sociológicas e, portanto, deve ser levada em conta nas análises sociológicas.

Estamos conscientes de que o conceito de raça foi uma das criações mais perversas, entre os séculos XVII e XIX, que serviu 
ao eurocentrismo e sua dominação sobre a terra. O conceito de raça é uma ficção formulada nos jogos de poder. Não se coloca em dúvida o fato de que o conceito de raça biológica foi o fulcro da mais poderosa formação ideológica da história. Foi a invenção do conceito de raça que racializou os povos, colocando-os em vantagens ou em desvantagens, tanto nos contextos econômicos internacionais, imperialistas, quanto nos nacionais em seus processos de homogeneização étnica e em seus processos civilizacionais. Estamos cientes também de que as teorias raciais científicas entraram em desuso, radicalmente, após a Segunda Guerra Mundial, quando em nome da raça cometeu-se o assassinato em massa nos campos de concentração. Mas o descrédito nas teorias raciais biológicas já vinha desde o começo do século. Em 1910, Franz Boas publicou Changes in the Bodily Format of Descendants of Immigrants [Modificações nos formatos dos corpos dos descendentes de imigrantes], argumentando que o tamanho da cabeça da primeira geração de italianos e judeus emigrantes nos Estados Unidos não conferia com o tamanho original. Embora Boas tenha recebido muitas críticas em decorrência da pouca consistência de suas demonstrações, feriu a noção de estabilidade física que sustentava a teoria racial, e introduziu a noção de plasticidade do corpo e da cultura (Barkan, 1992, p.83). O Brasil mais do que qualquer outro país, da Europa ou da América, abraçara a tese do descrédito no racismo científico a partir da década de 1930, especialmente com os trabalhos de Gilberto Freyre.

Não obstante, se o conceito de raça foi uma ficção biológica, não deixou de ter vida real muito influente em diversos contextos históricos. No Brasil, não se pode desprezar o peso que teve na construção da sua história. A taxonomia racial, pautada na "fábula das três raças", foi estruturante de todo o edifício social. "O triângulo das três raças [o branco, o negro e o índio] foi mantido como um dado fundamental na compreensão do Brasil" 
(Damatta, 1987, p.63). E mais, a "triangulação étnica" não só tornou-se ideologicamente dominante (o elogio da miscigenação foi feito sob a garantia da superioridade branca), mas abrange "a visão do povo, dos intelectuais, dos políticos e dos acadêmicos, de esquerda e de direita", como "motivação poderosa para investigar a realidade brasileira" (Damatta, 1987, p.63-69).

No século XIX, houve o medo de que a mistura das três raças impedisse o Brasil de ingressar na marcha do progresso; com a República, aplicou-se a lei da eugenia para embranquecer e integrar os mestiços à modernização brasileira e criou-se o mito da democracia racial; a geração de intelectuais pós Segunda Guerra Mundial, com a industrialização brasileira, viu que a questão racial no Brasil era uma questão social, cuja relação de classes jogava com a nossa herança escravista. A partir dos anos de 1980, numa aliança entre governo, academia e movimentos sociais, procurou-se não só compreender a histórica desigualdade sociorracial do Brasil, mas, principalmente, implementar políticas contra o racismo e contra a exclusão racial.

\section{A questão racial brasileira}

\section{O culturalismo}

O retrato do Brasil, sacado por quem enxergou o fantástico espetáculo das raças (Schwarcz, 1993), era surpreendentemente assustador. Pelas teorias raciais vigentes, o Brasil era tido como um país degenerado, "uma bela amostragem de barbárie, de ilusionismo barroco", na acepção de Ferdinand Dinis (apud Lima, 1984, p.132). "Tratava-se de uma população totalmente mulata, viciada no sangue e no espírito e assustadoramente feia”, queixava-se o conde Arthur de Gobineau, que permanecera no Brasil entre 1869 e 1870, como representante diplomático da 
França (Raeders, 1988, p.96). Pela identificação que fazia entre civilização, história e raças brancas, Gobineau, "The father of racist ideology" [O pai da ideologia racista] (Barkan, 1992, p.16), mostrava-se pessimista quanto ao futuro da América do Sul, onde os cruzamentos raciais e a degradação dos grupos europeus levariam à irremediável decadência (Ventura, 1988, p.191). Foi neste contexto que a imigração de europeus, na segunda metade do século XIX, apareceu como veículo impulsionador do branqueamento da nação. Nas palavras de Célia Maria Marinho de Azevedo (1987, p.75): “a imigração europeia era insubstituível como agente exclusivo de purificação étnica. Mesmo que o país alcançasse algum progresso material, sem brancos e embranquecidos, ele sofreria a falta de avanços morais e intelectuais".

No final do século XIX, com a abolição da escravidão (1888) e com a fundação da República (1889), as elites brasileiras tiveram que lidar com a maciça presença dos negros e da miscigenação. Definir ou interpretar a nação significava enfrentar a questão do cruzamento racial. Sociólogos, historiadores, naturalistas e médicos empenharam-se em estudar e discriminar os caracteres diferenciais das três raças formadoras da nacionalidade brasileira: a africana, a americana e a caucásica. Os médicos, tendo como maior representante Nina Rodrigues, trataram de observar a reação dos "vários tipos antropológicos", ou seja, tratar da "diferenciação psicológica das raças", diante dos estímulos sociais ou geográficos: "cada qual parecia ter uma individualidade própria, uma maneira peculiar, uma forma específica de reação" (apud Vianna, 1938, p.16). E não viam com bons olhos a mestiçagem, alardeando os efeitos deletérios dos cruzamentos raciais, atribuindo-lhes as mazelas, as doenças, as fraquezas físicas e mentais, e, consequentemente, a degeneração racial.

Todavia, nas primeiras décadas do século XX, devido aos processos modernizadores ocorridos no Brasil e à centralidade do debate intelectual em torno da questão da identidade nacio- 
nal, ocorreu a substituição da visão pessimista da contribuição das raças formadoras da sociedade brasileira por um enfoque positivo, no qual o intercurso racial transformou-se em indicador de tolerância e harmonia. Surge, portanto, uma "saída brasileira" para o problema étnico: fundir para integrar e extinguir as raças tidas como inferiores. Foram amplos os estudos para identificar os fatores "empobrecedores" do povo brasileiro e quais os remédios para saná-los (Flores, 2007). Ser branco já não significava o pertencimento genuíno ao grupo sanguíneo de origem europeia. Para Oliveira Viana:

em regra, o que chamamos mulato é o mulato inferior, incapaz de ascensão, degradado nas camadas mais baixas da nossa sociedade [...] Há, porém, mulatos superiores, arianos pelo caráter e pela inteligência, ou pelo menos capazes de arianização, ascendendo às altas camadas da nacionalidade e colaborando com os brancos na obra de organização e civilização do país. (apud Luca, 1999, p.176)

Gilberto Freyre (1998, p.289), em Casa-grande E e senzala informa que Roquette-Pinto encontrara várias evidências de ação europeizante entre os negros. Para Gilberto Freyre, a mestiçagem, além de possuir um ethos democrático (pela mobilidade social, vertical e horizontal), que herdamos dos portugueses, seria, na sua fase mais ativa, dotada do caráter de mobilidade biológica (Flores, 2007). A miscigenação teria criado em Portugal, ao longo de sua história, uma raça indefinida, o que tornou o português rico em aptidões: mobilidade, aclimabilidade e miscibilidade (Freyre, 1940).

Dominando espaços enormes, onde quer que pousasse, na África ou na América, emprenhava mulheres e fazia filhos, numa atividade genésica que tanto tinha de violentamente instintiva da parte do indivíduo, quanto de política calculada, de política 
estimulada, por evidentes razões econômicas da parte do Estado. (Freyre, 1940, p.39)

O pendor do português para a democratização social operaria como "dissolvente das forças que se solidificaram para criar sociedades de senhores e escravos, rígidas na separação de classes e de raças" (Freyre, 1940, p.55). As consequências seriam de ordem biológica, estética e ética. "O mestiço [em seu vigor híbrido] é dinâmico, biológica e culturalmente, na sua marcha para a relativa estabilização de traços a que o possam levar condições favoráveis à endogamia” (Freyre, 1940, p.44).

Assim, com Gilberto Freyre, a propalada "democracia racial” brasileira teve a mais refinada formulação, tornando-se um dos principais alicerces ideológicos da integração racial, suficiente para atrair a atenção internacional. Sucede, porém, que toda esta reflexão, articulada aos debates teóricos mundiais, carreia também aspectos significativos da ideologia nacionalista baseada na identidade, muitos deles responsáveis pelas frequentes críticas que a obra de Gilberto Freyre costuma receber. As melhores análises da obra do sociólogo concluem que ele trabalhou com uma definição fundamentalmente neolamarckiana de raça, isto é, uma definição que, baseando-se na ilimitada aptidão dos seres humanos para se adaptar às mais diferentes condições ambientais, enfatiza acima de tudo a sua capacidade de incorporar, transmitir e herdar as características adquiridas na sua interação com o meio físico (Araújo, 1994, p.39). A modificação da noção de raça biológica para a noção cultural de raça, aplicada ao meio e à história do grupo, das primeiras décadas do século XX, substituiu a raça física por raça linguística, histórica e psicológica. $\mathrm{O}$ termo raça, praticamente inútil à época foi substituído pelo termo etnia, um silogismo para definir a identidade da nação (Todorov, 1993).

Freyre observou explicitamente, em $O$ mundo que o português criou, que "o processo de nacionalização é o processo de con- 
versão, nos limites do espaço e do tempo". Afinal, disse ele, "o indivíduo torna-se brasileiro pela mesma forma ou pelo mesmo processo por que se torna católico”, processo que já se podia perceber pelas "evidências de abrasileiramento no extremo sul do Brasil", do alemão e de outros colonos, "pelo gesto, pelo ritmo de andar, pela prática de atos tradicionalmente brasileiros" (Freyre, 1940, p.31). "[...] quase todo homem de Blumenau ou de Santa Cruz, de Joinville ou de São Leopoldo, se já não é um meio convertido [...] Não tardará a ouvir vozes irresistíveis no fundo das matas e das águas das tradições brasileiras: 'Fritz, Fritz, por que me persegues?"” (Freyre, 1940, p.34). Apesar da apologia do mestiço, Freyre valorizava a continuidade dos valores europeus. O português "foi o transportador para os trópicos de valores essenciais de cultura europeia" (Freyre, 1940, p.40).

Se no século XIX, os viajantes estrangeiros viam no país um "laboratório racial" para comprovar a "degeneração" advinda do cruzamento racial, agora a tese da plasticidade cultural e física encontrava no Brasil um novo campo de experimentação (Flores, 2010). Oliveira Vianna (1938, p.16), embora ainda preso às teses biológicas, considerou o Brasil um "centro por excelência dos estudos de raça”, já que o país recebera etnias diversas. "Só entre populações heterogêneas, onde se caldeiam os tipos antropológicos mais diferentes, onde as raças mais primitivas se misturam com as raças arianas; só aí é que elas podem ser estudadas em condições ótimas de eficiência investigadora” (Vianna, 1938, p.19-20). Roquette-Pinto fez oposições claras à tese "degeneracionista da mestiçagem", afirmando que o "branqueamento" viria com a educação e a saúde (Schwarcz, 1993, p.96). Arthur Ramos, ex-aluno de Nina Rodrigues, sugeriu substituir os termos raça por cultura e mestiçagem por aculturação (Maio; Santos, 1996, p.111), defendendo a compreensão do Brasil como um "laboratório de civilização", termo cunhado pelo historiador norte-americano, Rudiger Bilden, em 1929 (Maio, 1999, p.142). 
Quando Arthur Ramos assumiu, em 1949, a direção do Departamento de Ciências Sociais da Unesco (Organização das Nações Unidas para a Educação, Ciência e Cultura), levou para lá suas ideias, alicerçadas na proposta de uma antropologia de intervenção, que procurasse viabilizar a "integração de negros e índios ao mundo moderno”. Embora acreditasse na existência da "democracia racial" ou da cooperação entre as raças no Brasil, Arthur Ramos reconheceu a presença do preconceito racial; assinalou a relevância do estudo da inserção dos indivíduos em grupos, estratos e classes sociais para entender as desigualdades étnico-raciais; para ele, o problema da desigualdade racial vinha junto ao tema da incorporação de segmentos sociais marginalizados (Maio, 1999, p.142).

\section{A descoberta da raça sociológica}

A Unesco vinha, desde os finais da década de 1940, refletindo a perplexidade da comunidade científica mundial e de dirigentes políticos diante das ações catastróficas levadas a cabo no decorrer da Segunda Guerra Mundial em nome da raça. A inquietação tornou-se ainda mais aguda com a persistência do racismo em diversas partes do mundo, com o surgimento da Guerra Fria, com o processo de descolonização africana e asiática e com a perpetuação de grandes desigualdades sociais em escala planetária. Diante desse cenário, a Unesco, “em fase de extremo otimismo, munida da razão iluminista, não mediu esforços em encontrar soluções universalistas que cancelassem os efeitos perversos do racionalismo, do nacionalismo xenofóbico e das disparidades socioeconômicas" (Maio, 1998, p.17). Por ocasião da sua 5a Sessão da Conferência Geral, em 1950, realizada em Florença, surgiu a 1a Declaração sobre Raça, negando qualquer associação determinista entre características físicas, comportamentos sociais e atributos morais. O Brasil, conside- 
rado um exemplo de experiência "singular e bem-sucedida" (Maio, 1999, p.146) no campo das interações raciais, em comparação com os Estados Unidos e com a África do Sul, foi escolhido para servir de "laboratório socioantropológico" (Maio, 1999, p.144). Marcos Chor Maio considera que, embora a proposta da "pesquisa-piloto", como fora denominado o projeto da Unesco para o Brasil, contivesse certa dose de ingenuidade, os resultados a que se chegou foram consideráveis. "O 'Projeto Unesco' foi um agente catalisador” (Maio, 1999, p.142).

O objetivo político da Unesco, ao apresentar o Brasil como modelo para o mundo, era o de realizar investigações para determinar os fatores que contribuíam para a "existência de relações harmoniosas entre raças e grupos étnicos" (Maio, 1998, p.18). Isto possibilitou o trabalho conjunto entre cientistas sociais nacionais e estrangeiros, impulsionando o desenvolvimento de um pensamento que já em curso. No seu interior, os pesquisadores brasileiros encontraram condições favoráveis às suas investigações, inclusive nos meios acadêmicos, chefiados por especialistas brasileiros - Florestan Fernandes, Thales de Azevedo, Oracy Nogueira, L. A. Costa Pinto e outros (Maio, 1999, p.154).

Por outro lado, pesquisadores internacionais envolveram-se no projeto e reforçaram a parceria com os brasileiros: o antropólogo Alfred Métraux, com larga experiência de trabalho etnológico (índios e negros) tanto na América do Sul quanto na América Central; Roger Bastide, professor da Universidade de São Paulo desde 1938, importante referência nos estudos relativos à cultura afro-brasileira e autor de uma série de trabalhos sociológicos sobre o negro no Brasil; o antropólogo norte-americano Charles Wagley que, desde o final dos anos de 1930, tinha estreitas ligações com o Brasil, especialmente no estudo de comunidades indígenas (Maio, 1999, p.144). Cientistas sociais brasileiros e estrangeiros haviam assumido como desafio intelectual não apenas tornar inteligível o cenário racial brasileiro, 
mas também responder à recorrente questão da incorporação de determinados segmentos sociais à modernidade, fazendo jus à intenção inicial de Arthur Ramos, que havia falecido antes do término do projeto.

Marcos Chor Maio (1998, p.17), ao apresentar a reedição do livro $O$ negro no Rio de Janeiro, de Luiz de Aguiar Costa Pinto, diz que essa publicação não significa apenas o reconhecimento da importância de uma obra, mas também representa um momento de reflexão a respeito do "Projeto Unesco". Costa Pinto participou do debate acerca do estatuto científico do conceito de raça, que resultou na 1 a Declaração sobre Raça, em 1950, e articulou um acordo para que se realizasse pesquisa também no Rio Janeiro, numa área metropolitana.

O trabalho de Costa Pinto, segundo Marcos Chor Maia, apresenta um conjunto de críticas às pesquisas etnográficas da fase "afro-brasileira" (final do século XIX até os anos 1940), por se deterem em características físicas e psíquicas intrínsecas às raças, aos traços culturais, aos processos de aculturação. Faltava ao estudo do problema racial do Brasil, uma leitura sociológica para os desafios ditados pelo desenvolvimento capitalista, pela mobilidade social e pelas novas relações das classes sociais derivadas da passagem da situação de escravo à condição de proletário até chegar ao negro de classe média (Maio, 2009). A grande contribuição, segundo Maio, do livro O negro no Rio de Janeiro refere-se à compreensão do preconceito racial que emerge no seio de uma sociedade em processo de industrialização e urbanização. Houve alinhamento de parcelas de pretos e pardos às reivindicações proletárias; a mobilidade social leva setores dominantes, ameaçados pela perda de posições, a tomar atitudes racistas; o processo de mobilidade social vertical criou uma diferenciação interna entre os negros, formando uma "elite negra" que trata de afirmar a negritude. "A nova forma de ascensão dos negros não é mais individual e não se interessa em 'branquear- 
-se', como acontecia na sociedade tradicional, paternalista, especialmente no século XIX” (Maio, 2009, p.333). Essa dinâmica favorece a criação de vários movimentos sociais de corte racial, o que veremos mais adiante.

Outro nome de destaque no contexto do "Projeto Unesco" foi o de Oracy Nogueira. Nas suas pesquisas sobre preconceito racial no Brasil e nos Estados Unidos, ele formulou diferenças entre os dois países: para o contexto brasileiro, Nogueira concebe a existência do "preconceito de marca" e para o norte-americano, o "preconceito de origem" (Cavalcanti, 2009). O primeiro elege o fenótipo (a aparência racial) como critério para a discriminação. Inúmeras gradações classificatórias consideram não só as nuances da cor - preto, mulato, mulato claro, escuro, escuro, pardo, branco -, como também traços fisionômicos como nariz, lábios, cor dos olhos, tipo de cabelo. A concepção de branco e não branco varia assim muito de indivíduo para indivíduo, dentro da mesma família ou do mesmo grupo social, de classe para classe, de região para região (Cavalcanti, 2009, p.260). O segundo, o "preconceito de origem", dá-se pelo nascimento. A origem parental do indivíduo o classifica e o vincula ao grupo discriminado. "Negro" é quem é reconhecido como tal, em sua comunidade, independente da aparência física (Cavalcanti, 2009, p.261).

No Brasil, segundo Nogueira, o preconceito discrimina mediante a preterição. Ao concorrer em igualdade de condições, a "pessoa escura" seria sempre preterida por uma "pessoa mais clara". Entretanto, se a "pessoa escura" demonstrar superioridade em inteligência, condição econômica, diplomacia ou perseverança permite que se lhe "abra uma exceção". Nesse tipo de preconceito, as relações pessoais de amizade ou admiração cruzam frequentemente as fronteiras da "marca"; a consciência da discriminação é intermitente, e o grupo discriminado, por ser mais indefinido, tende a reagir de modo mais individualizado. 
A etiqueta das relações raciais, por sua vez, tende a controlar o comportamento do grupo discriminador, de modo a evitar a suscetibilidade ou a humilhação do grupo discriminado. A "cor" entendida como metonímia da aparência racial, emerge então como categoria duplamente cultural. Trata-se de uma escolha classificatória (não é, por exemplo, a ascendência que interessa). Ao mesmo tempo, o ato concreto de classificação de uma pessoa como "branca", "mulata" mais ou menos "escura", ou "preta" resulta do cruzamento da aparência com outros critérios igualmente pertinentes para a definição da situação em jogo. De tal modo que, nesse sistema relacional, a discriminação social pode conviver com a intimidade pessoal (Cavalcanti, 2009, p.263-264).

Em 1960 sai o livro Cor e mobilidade social em Florianópolis, de Fernando Henrique Cardoso e Octavio Ianni, como um desdobramento do Projeto Unesco, para sanar uma "falta", conforme justificam os autores na introdução do livro, já que as investigações se tinham concentrado nas comunidades localizadas no Norte, Nordeste e Leste do país. No Sul, apenas a cidade de São Paulo tinha recebido alguma atenção. Era preciso verificar como fora o processo de integração do negro no Brasil meridional, colonizado por grandes contingentes europeus, principalmente alemães, italianos e poloneses, e que, portanto, não se utilizara em grande escala da mão de obra escrava (Cardoso; Ianni, 1960, p.20-21).

No prefácio de Cor e mobilidade social em Florianópolis, Florestan Fernandes destaca a importância da obra de Ianni e Cardoso, pois, mostra o quanto nos falta de "experiências históricas, suscetíveis de intensificar e dar solidez ao desenvolvimento da democracia social no Brasil" (Fernandes, 1960, p.12). Se "dispomos de algumas realizações que merecem ser preservadas, por serem potencialmente positivas", no campo da "tolerância convencionalizada nas relações raciais", não existe, todavia, 
democracia racial efetiva. "Esta pode satisfazer às exigências do 'bom-tom', de um discutível 'espírito cristão' e da necessidade prática de 'manter cada um em seu lugar'" (Fernandes, 1960, p.10). Mas a nossa suposta democracia racial "não aproxima realmente os homens senão na base da mera coexistência no mesmo espaço social", regulado por códigos que consagram a desigualdade. Caberia, segundo Florestan Fernandes, incrementar a consciência de cidadania e o exercício mais eficaz da democracia (Fernandes, 1960, p.10). Assim, segundo ele, a pesquisa de Ianni e Cardoso alargou "nossas possibilidades de explicar, sociologicamente, as bases e os produtos sociodinâmicos das relações raciais na sociedade brasileira”, mostrou "as conexões existentes entre as bases econômicas do sistema social e a organização das relações raciais", explicitou "as origens e as funções sociais dos estereótipos raciais" (Fernandes, 1960, p.16 e 18).

Ao analisar o livro Cor e mobilidade social em Florianópolis, Elide Bastos (2009) levanta a questão sobre a relação existente entre diversidade e desigualdade na obra, e conclui que os autores perceberam que a desigualdade não se reduz à oposição branco-preto, nem à oposição riqueza-pobreza. A negação à verdadeira participação política, social e aos bens culturais promove e configura fortemente a noção de desigualdade. A discriminação racial influi na mobilidade social, ainda mais que esse preconceito leva à internalização, pelos negros, de papéis sociais que se constituem em obstáculos à ascensão na sociedade. Denunciando o racismo, portanto, os autores negam o mito da "democracia racial" na sociedade brasileira, mostrando como as relações sociais geradas no regime escravocrata se estendem à sociedade brasileira posterior à abolição, de modo a resguardar privilégios e impedir a invocação de direitos civis, políticos e sociais. 


\section{A classificação racial no Brasil}

\section{Estatísticas racializadoras}

A "fábula das três raças", como formadora da população do país, foi inaugurada quando Von Martius publica o livro Como se deve escrever a historia do Brazil (1845). "Qualquer um que se encarregar de escrever a história do Brasil”, assevera Martius, jamais poderá deixar de considerar a participação das três raças: "a de cor cobre ao americano; a branca [...] e enfim a preta ou etíope [...]” (Martius, 1982, p.87). Em seguida, aparece o livro História geral do Brasil (1854) de Francisco Adolfo de Varnhagen, que consolida a história racial brasileira, com base nas características peculiares às três raças formadoras da nação. A criação da história nacional e o estudo da população do país eram exigências sine qua non no processo de formação do Estado nacional moderno. Não foi à toa que o historiador Varnhagen tenha sido o emissário oficial enviado ao Congresso Internacional de Estatística, em São Petersburgo, Rússia, no contexto preparatório para a realização do primeiro Censo Demográfico do Brasil, de 1872 (IBGE, 2011, p.208).

O problema que o Brasil precisava enfrentar era o de estabelecer categorias raciais para o levantamento estatístico da sua população. Como classificar as raças no Brasil? Quando se inventou, entre os séculos XVII e XIX, na Europa, a classificação racial dos grupos humanos, introduziu-se a categoria cor para identificá-las. Os povos do leste e os ameríndios eram tidos como pertencentes à raça amarela; os europeus, ou caucasoides, formariam a raça branca; e os povos da África Subsaariana, os negroides, designariam os negros. Assim, no Brasil, o recenseamento de 1872 lançou mão da forma usual de classificar e hierarquizar racialmente a população pela cor da pele, inaugurando, assim, o sistema de cores para a sua classificação racial (IBGE, 2013, p.88). 
No quadro abaixo, podemos acompanhar o processo de introdução do quesito cor ou raça nos Censos Demográficos realizados no Brasil, a partir de 1872.

Tabela 1: Processo de introdução do quesito cor ou raça nos Censos Demográficos realizados no Brasil

\begin{tabular}{c|c|c|c|c|c|l}
\hline 1872 & Branca & Preta & Parda & Cabocla & & \\
\hline 1890 & Branca & Preta & Mestiça & Cabocla & & \\
\hline 1900 & - & - & - & - & & \\
\hline 1910 & & & & & & \\
\hline 1920 & - & - & - & - & & \\
\hline 1930 & & & & & & \\
\hline 1940 & Branca & Preta & - & - & Amarela & \\
\hline 1950 & Branca & Preta & Parda & & Amarela & \\
\hline 1960 & Branca & Preta & Parda & & Amarela & \\
\hline 1970 & Branca & Preta & - & & Amarela & \\
\hline 1980 & Branca & Preta & Parda & & Amarela & \\
\hline 1991 & Branca & Preta & Parda & & Amarela & Indígena \\
\hline 2000 & Branca & Preta & Parda & & Amarela & Indígena \\
\hline 2010 & Branca & Preta & Parda & & Amarela & Indígena \\
\hline
\end{tabular}

Fonte: Recenseamento do Brazil 1872-1920; IBGE, Censo Demográfico 1940/2010 (IBGE, 2011, p.16).

Observa-se que o primeiro recenseamento, de 1872, definiu quatro opções para classificação racial: branca, preta, parda e cabocla (esta última dirigia-se a contabilizar a população indígena), cristalizando o sistema de cores para caracterizar a nação brasileira. No Censo de 1891, introduziu-se a categoria indígena e o termo "pardo" foi substituído por "mestiço", categoria que melhor convinha à ideologia do branqueamento, conforme vimos anteriormente. Nos Censos de 1900 e 1920, as informações sobre cor ou raça não foram coletadas e em 1910 e 1930, não foram realizadas operações censitárias no país. A partir do Censo de 1940, aparece a cor amarela para contabilizar especialmente a participação japonesa que resultara da sua imigração ocorrida fundamentalmente entre 1908 e 1930. Observa-se que no Censo de 1940, a classificação restringe-se à categoria cores - branca, 
preta, amarela. Os que não se encaixavam em nenhuma das três categorias, recebiam um traço no espaço correspondente à cor que, na fase das análises dos resultados, eram codificados como pardos (IBGE, 2011, p.14).

Já nos Censos de 1950 e 1960 é reincorporado o grupo de pardo, e são esses os primeiros censos a explicitar em suas instruções de preenchimento o respeito à resposta da pessoa recenseada, sendo a primeira referência ao uso da autodeclaração (IBGE, 2011, p.15). Em 1970, a categoria de pardo volta a ser excluída da pesquisa, retornando em 1980, a ser utilizada, desta vez no questionário de amostra. Finalmente, no último Censo realizado em 2010 foram mantidas as categorias branca, preta, parda, amarela e indígena. Foi o primeiro Censo em que as pessoas identificadas como indígenas foram questionadas a respeito de sua etnia e língua falada.

É importante ressaltar que nos últimos 50 anos, a estrutura racial brasileira vem se alterando, com a redução proporcional de brancos e pretos em relação ao crescimento dos pardos, como se observa nos gráficos e na tabela do Censo 2010 que estão abaixo.

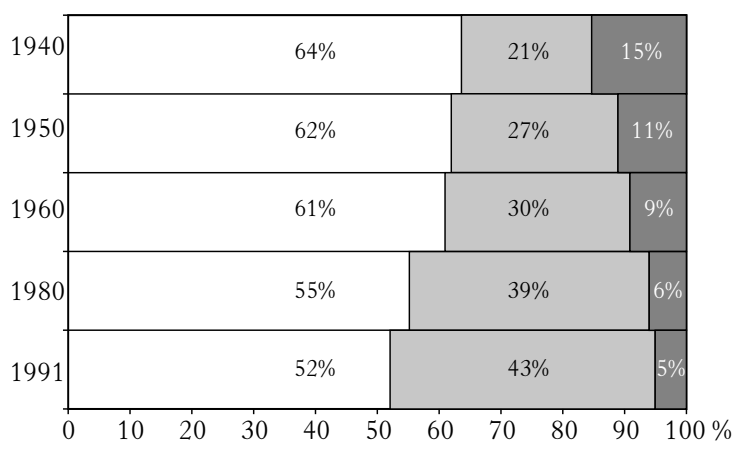

\begin{tabular}{|l}
\hline$\square$ Branca $\square$ Parda $\square$ Preta \\
\hline
\end{tabular}

Gráfico 1: Participação relativa segundo a cor - População total - Brasil, (19401991)

Fonte: Sachs; Vilheim; Pinheiro (2001, p.35). 

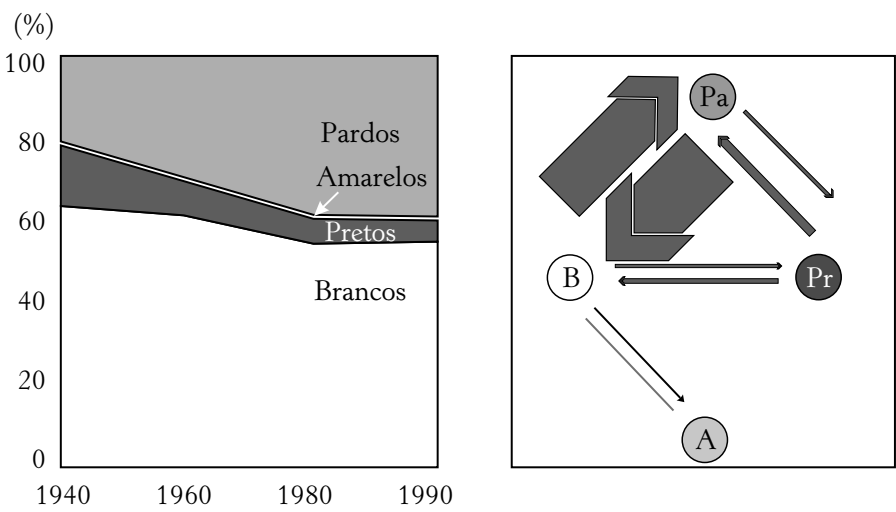

Gráfico 2: Composição étnica e casamentos interétnicos Fonte: Sachs; Vilheim; Pinheiro (2001, p.401).

Tabela 2: Participação em números absolutos e relativos da população brasileira, segundo a cor, no Censo Demográfico de 2010

\begin{tabular}{l|c|c}
\hline \multicolumn{1}{c|}{ Cor } & Números absolutos & Números percentuais \\
\hline Branca & 91.051 .646 & $47.7 \%$ \\
\hline Preta & 14.517 .961 & 7.6 \\
\hline Amarela & 2.084 .288 & 1.0 \\
\hline Parda & 82.277 .333 & 43.1 \\
\hline Indígena & 817.963 & 0.4 \\
\hline Sem declaração & 6.608 & 0.0 \\
\hline
\end{tabular}

Fonte: Censo Demográfico - 2010.

\section{A cor autodeclarada}

A Pesquisa das Características Étnico-raciais da População - Um estudo das categorias de classificação de cor ou raça (Pcerp/2008), realizada pelo IBGE em 2008, por amostragem, nos estados de Amazonas, Paraíba, São Paulo, Rio Grande do Sul, Mato Grosso e Distrito Federal, teve por objetivo "aprimorar" o sistema de classificação de cor e raça no Brasil para subsidiar as estatísticas oficiais neste quesito. Era a terceira vez em que o próprio IBGE levantava informações para aperfeiçoar seus 
instrumentos de aferição das características raciais da população utilizados nos Censos Demográficos. Nas ocasiões anteriores, tal investigação ocorreu na Pesquisa Nacional por Amostra de Domicílios (Pnad), realizada em 1976, e na Pesquisa Mensal de Emprego (PME), realizada em 1998.

O sistema de classificação racial no Brasil, baseado na cor e no fenótipo do indivíduo, incorpora negociações e conflitos identitários que se processam em contextos de interação social. As gradações classificatórias consideram não só as nuances da cor - preto, mulato, mulato claro, escuro, pardo, branco -, como também traços fisionômicos - nariz, lábios, cor dos olhos, tipo de cabelo - em meio a diversos complicadores sociais, subjetivos, geracionais, políticos, econômicos, que fazem variar a percepção e a concepção de branco e não branco. Costuma-se citar uma pesquisa realizada por Harris, em 1970, a qual levantou 492 termos para definir a cor dos entrevistados, ou a Pnad realizada pelo IBGE em 1976 que, pela autodefinição em respostas livres, formou uma lista de 135 cores, entre elas, acastanhada, agalegada, alva escura, azul-marinho, bem clara, bem morena, branca queimada, cor de café, cor de canela, cor-de-rosa, cor firma, jambo, laranja, melada, meio morena, morena bem chegada, rosa, roxa, sarará, trigueira, verde... Diante de tanta variedade, ao se deixar o entrevistado se autodefinir, concluiu-se por um quadro mais fechado: o brasileiro a ser recenseado pode escolher apenas entre quatro cores: branca, parda, negra, amarela (Azevedo, 2004).

A iniciativa da Pcerp/2008 atendia também aos compromissos assumidos pelo Brasil na III Conferência Mundial de Combate ao Racismo, Discriminação Racial, Xenofobia e Intolerância Correlata, realizada em Durban, na África do Sul, em 2001. Naquele ano foram adotadas a "Declaração e o Programa de Ação de Durban” que tratavam especificamente das políticas e práticas de coleta e agregação de dados nessa área.

A meta da Pcerp/2008 era compreender o atual sistema de classificação da cor ou raça, no Brasil, nas pesquisas domicilia- 
res, aproximando o entrevistado do tema da autoidentificação racial para captar o grau de percepção dos fenômenos sociais de discriminação baseados na cor ou raça das pessoas. Em diversas variáveis de perguntas, cujas respostas foram processadas em um conjunto de 65 tabelas, a Pcerp/2008 apresentou cifras que demonstram graus de correlação entre cor/raça e características familiar, socioeconômica e cultural; influência da cor/raça na discriminação social; correlação entre subjetividade do indivíduo na sua autoidentificação racial; hierarquização de classe e construção da identidade; grau de recorrência a denominações de cor, raça, etnia e origem, tanto do ponto de vista da composição étnica da população como das diversidades regionais; correlação entre níveis de instrução e ocupação e grupos de cor/ raça; correlação entre cor/raça, sexo, grupos de idade e geração.

A Pcerp/2008 trouxe possibilidades de respostas abertas, permitindo aos entrevistados expressarem a reconhecida multietnicidade que caracteriza a população do país. Possibilitou que as respostas aplicassem novos termos para ampliar o escopo de identificação, sem sair das categorias clássicas de identificação racial. Perguntou se a pessoa se reconhecia como afrodescendente; ou como indígena (especificar etnia e língua); ou amarelo; se se reconhecia como negro, como preto, ou como branco. O resultado Pcerp/2008, traduzido em dados demográficos, publicado em 2011, conforme citado acima, recebeu imediatamente um volume complementar, publicado em 2013, sob o título Características étnico-raciais da população-classificações e identidades, reunindo uma coletânea de artigos de especialistas no tema, com análises críticas da dinâmica racial no Brasil. As análises desses especialistas focaram três eixos temáticos: 1) reflexões sobre a noção de raça; 2) análise sobre a classificação da cor ou raça em perguntas abertas; 3 ) e o tema da mobilidade social, educacional, intergeracional, por categorias raciais.

O estudo considerou que o conceito de raça é exclusivamente uma construção sócio-histórica. No Brasil, esta constatação leva 
em conta a problemática do encontro com o "outro" na sua alteridade, a construção de taxonomias a partir do século XVIII e a maneira como a ideologia racial determinou uma classificação hierarquizada, herdeira dos processos de colonização e escravidão. E, pela análise das tabelas produzidas pelo Pcerp/2008, concluiu-se que o papel da desigualdade racial controla diversas outras dimensões da vida cotidiana que influenciam na mobilidade social. Ser "não branco" continua a ser um fator para menor mobilidade ascendente e maior mobilidade descendente. No Brasil, o preconceito racial se caracteriza por ser preponderantemente de marca. A desigualdade racial e a repetição frequente dos estereótipos desqualificadores contribuem para que os grupos discriminados tenham, em média, as piores condições de vida (IBGE, 2013, p.11).

A análise sobre a classificação racial dos indivíduos foi feita por Rafael Guerreiro Osorio, no quarto capítulo do referido volume (IBGE, 2013, p.83). O autor chegou à conclusão de que as definições de cor ou raça apresentaram complexidades, diante do processo de construção de identidades étnico-raciais, individuais e coletivas, mas os resultados obtidos pela Pcerp/2008 corroboram a adequação do atual sistema classificatório de cor ou raça do IBGE. Há coincidência em grande grau entre a identificação da própria cor ou raça feita pelo entrevistado com a que é atribuída pelo entrevistador; a população representada continua a escolher uma grande quantidade de termos para se definir quanto à cor ou raça, mas 95\% escolhem dentro de um conjunto restrito de oito categorias, no qual inclui as quatro usadas atualmente no Censo Demográfico (preta, parda, amarela e branca). As outras são negra, morena, morena clara e clara. A pesquisa também revelou que a maior parte, $63,7 \%$, da população representada pelos entrevistados considera que a cor ou a raça influencia a vida das pessoas no Brasil. A informação nova e relevante trazida pela Pcerp/2008 é sobre o quanto as pessoas têm conhecimento da própria cor ou raça. No total das seis Unidades da Federação 
pesquisadas, 96\% das pessoas de 15 anos ou mais de idade afirmaram saber qual a sua própria cor ou raça (IBGE, 2013, p.89).

Rafael Guerreiro Osorio refuta, assim, a crítica comum à classificação racial do IBGE, de que seria pobre em face da riqueza do vocabulário empregado pelos brasileiros para designar sua identidade racial, restringindo-o aos termos branca, parda, preta e amarela. Osorio diz que, a despeito da enorme variedade de cores que apareceu na Pnad de 1976 (136 categorias registradas), 95\% das respostas espontâneas se enquadravam em apenas sete categorias: $57 \%$ dos entrevistados escolheram branca, preta, parda ou amarela para designar de forma espontânea a própria cor, outros $38 \%$ das respostas estavam concentradas em três termos: morena, morena clara e clara. Na PME, realizada em 1998, 94\% das respostas livres concentraram-se nas mesmas sete cores. Na Pcerp/2008, essas sete categorias também estão entre as mais frequentes, porém a percentagem dos que as escolhem é um pouco menor, 88\% (IBGE, 2013, p.90).

A grande novidade trazida pelo Pcerp/2008, em relação às pesquisas anteriores, foi o crescimento da preferência pela classificação negra e o decréscimo da preferência pela cor morena. $\mathrm{O}$ termo negro - em decorrência da valorização da negritude, supõe o analista - provavelmente abarca os que no Censo Demográfico se declaram preto ou pardo, já que lá as opções são fechadas. A cor morena, declarada nas respostas espontâneas, deve corresponder, em parte, aos que não apreciam a condição de pardo. A categoria preta também enfrenta certa rejeição. Portanto, para cor negra migraram pardos, pretos e morenos. Se a cor negra passasse a ser uma categoria da classificação, não mudaria substancialmente, no Censo Demográfico do IBGE, a proporção da somatória das faixas compostas por pretos e pardos em relação à faixa da cor branca, mantendo a comparabilidade com a série histórica e todo o conhecimento acumulado sobre o assunto (IBGE, 2013, p.91).

Como conclusão geral, a análise demonstrou que as evidências da Pcerp/2008 avalizaram o sistema de classificação racial 
do IBGE, pois a população em geral sabe qual é seu enquadramento, definido principalmente pela cor da pele; e a maioria usa uma das categorias do Instituto, na resposta espontânea, para se classificar. Além disso, a Pcerp/2008 revelou que a população representada majoritariamente considera que a cor ou a raça influencia socialmente a vida das pessoas, o que reforça a necessidade de continuidade dos estudos sobre as consequências do pertencimento a grupos raciais (IBGE, 2013, p.95).

A autoatribuição funciona tão bem quanto à heteroatribuição, dado o baixo grau de discordância entre entrevistadores e entrevistados, concentrado nos tipos limítrofes, mais difíceis de serem classificados. Obviamente, a classificação não é absolutamente precisa ou objetiva, e nem poderia ser, pois o fenômeno que pretende captar varia circunstancialmente. As categorias abrangentes e de fronteiras fluidas da classificação permitem lidar com essa imprecisão: embora não se possa, a partir dos resultados de seu emprego, saber exatamente qual é o fenótipo nacional ideal do pardo, ou do preto, ou do branco, sabe-se que identificou pessoas que se enquadram nessas categorias em seus contextos relacionais. (IBGE, 2013, p .96)

\section{O movimento negro}

\section{A falácia da democracia racial}

Esta característica da população brasileira - cuja complexidade de identificação requer toda uma maquinaria classificatória não só do ponto de vista institucional, mas também do ponto de vista da própria subjetividade do indivíduo, que pode mudar de cor ou ter a percepção da sua cor de acordo com a sua inserção na dinâmica social - fundamenta os argumentos contrários às "políticas raciais afirmativas" ou à "discriminação positiva” que veem nelas "a 'vitória' de uma taxonomia bipo- 
lar sobre a velha e tradicional taxonomia de muitas categorias" (Maggie; Fry, 2004, p.70). Há o receio de que o país de "raças misturadas" possa ser substituído por um país de "raças distintas", de duas raças, branca e preta, de modo a impedir que continuemos a nos identificar com "o Macunaíma do modernismo brasileiro” (Maggie; Fry, 2004, p.68), o que colocará em risco o ideal de democracia racial (a saber: relações raciais harmônicas ou pouco conflituosas). Democracia racial que chamara a atenção da Unesco, escolhendo o Brasil como exemplo de uma consciência política que primava pela harmonia entre as raças e podia dar a lição de como erradicar o racismo no mundo.

Pelo menos durante toda a primeira metade do século XX, as interpretações sobre as relações raciais no Brasil partiam da imagem de um "paraíso racial”. E, embora, as elites vissem como "problema" a integração da população negra pós-abolição no processo de modernização do país, a miscigenação advinda do intercurso racial (tanto sexual quanto no âmbito das sociabilidades) acabou por ser positivada como indicador de tolerância e harmonia. Essa crença na democracia racial e a apologia da mestiçagem, alicerces da interpretação do Brasil como um país que incluía os negros na sociedade, favoreceram a tese de que no país não havia uma consciência racial. Donald Pierson (1971), em Pretos e brancos na Bahia, fez comparações entre a capital da Bahia, Salvador, e Chicago, sua cidade natal. Ao partir da premissa de que no Brasil, as relações inter-raciais tenderam a incorporar os não brancos ao mundo dos brancos num processo de "aculturação", Pierson concluiu que no Brasil não existiam conflitos raciais. No Congresso Afro-Brasileiro de 1930, ${ }^{5} \mathrm{em}$ Salvador, Pierson afirmou que os intelectuais se ocuparam de questões culturais e da tradição da cultura negra sem nenhuma

5 Dois congressos afro-brasileiros, de caráter científico, aconteceram na década de 1930: o primeiro em Recife, organizado por Gilberto Freyre; e o segundo em Salvador, sob a organização de Édison Carneiro. 
pauta política direcionada para discussão de conflitos raciais, o que denotava "relativa ausência de qualquer consciência de raça por qualquer parte dos pretos ou mestiços, ou de qualquer outro grupo" (Rios, 2010, p.8).

Não obstante, a mistura racial e a fluidez das relações raciais além de não significarem maiores vantagens para a boa parte dos negros brasileiros (Telles, 2013, p.312), tampouco significam que se possa concluir daí que tenha havido ausência de ação política de conteúdo racial. Ao acompanharmos os momentos de mobilização negra ao longo do século XX, percebemos que os movimentos raciais não foram eventos isolados e esporádicos. Representam uma história de protesto e de luta. Os negros se mobilizaram para se afirmar politicamente. A mobilização foi alta no contexto de 1880. Continuou efetiva e constante, embora em nível mais baixo, durante a primeira metade do século XX. Em 1925, o principal jornal negro, em São Paulo, O Clarim d'alvorada, havia pedido "um grande partido político, composto exclusivamente de homens de cor" (Andrews, 1991, p.32). A partir das décadas de 1970 e 1980, o movimento ganhou não só mais força, mas também novas implicações políticas, sobre as quais falaremos adiante.

A tardia abolição da escravidão (1888) e a instalação da República Brasileira (1889) não promoveram mudanças efetivas para a população negra. A marginalização política, devida às limitações do regime republicano no que se referia ao direito do voto e à representação; a marginalização social e psicológica devida à discriminação amparada nas doutrinas do racismo científico e na ideologia do branqueamento; a marginalização econômica, devida à preferência pela mão de obra estrangeira, são algumas das explicações gerais para a exclusão estrutural dos herdeiros do sistema de escravidão, no Brasil. A resistência a esse quadro deu-se através de diversas associações trabalhistas e outras que podem ser designadas como recreativas ou culturais, formadas por negros, ex-escravos e seus descendentes. 
Entre clubes e grêmios, apareceram em São Paulo o Club 13 de Maio dos Homens Pretos (1902), o Centro Literário dos Homens de Cor (1903), a Sociedade Propugnadora 13 de Maio (1906), o Centro Cultural Henrique Dias (1908), a Sociedade União Cívica dos Homens de Cor (1915), a Associação Protetora dos Brasileiros Pretos (1917); no Rio de Janeiro, o Centro da Federação dos Homens de Cor; em Pelotas/RS, a Sociedade Progresso da Raça Africana (1891); em Lages/SC, o Centro Cívico Cruz e Souza (1918). A agremiação negra mais antiga desse período foi o Clube 28 de Setembro (1897), em São Paulo. As maiores foram o Grupo Dramático e Recreativo Kosmos (1908) e Centro Cívico Palmares (1926) ambos em São Paulo (Domingues, 2007a, p.103).

As associações negras trabalhistas foram formadas, principalmente, por portuários e ferroviários, constituindo uma espécie de sindicato. Entre 1907 e 1937, havia cerca de 123 associações negras em São Paulo (Domingues, 2007a, p.104), em Porto Alegre, entre 1889 e 1920, foram contabilizadas 72 e, em Pelotas 53 associações entre 1888 e 1929 (Muller, 1999, p.104). Algumas associações eram compostas apenas por mulheres, como a Sociedade Brinco das Princesas (1925, São Paulo) e a Sociedade de Socorros Mútuos Princesa do Sul (1908, Pelotas/RS). Grande parte das mulheres destas associações também era também integrante da Frente Negra Brasileira (FNB), fundada em 1931 (Domingues, 2007a, p.104).

Outro importante movimento - pós-abolicionista - configurou-se na chamada Imprensa Negra, termo utilizado no meio acadêmico para designar títulos de jornais e revistas publicados em São Paulo, no início do século XX, que se destacaram no combate ao preconceito e na afirmação social da população negra. Nos jornais apareciam denúncias, poesia, eventos sociais, concursos e festas que dificilmente sairiam em outros do período. Dentre os principais jornais e revistas da Imprensa Negra, destacam-se: jornais Getulino (1916-1923), O Clarim d'alvorada (1929-1940), revista Senzala (1946), A voz da raça, da Frente 
Negra Brasileira (1933-1937), e mais tarde a revista Quilombo (1950), editada por Abdias do Nascimento. ${ }^{6}$

Em 16 de setembro de 1931, foi oficialmente fundada a Frente Negra Brasileira - União Político-Social da Raça (FNB), ${ }^{7}$ considerada como uma instituição ${ }^{8}$ que sucederia o Centro Cívico Palmares, fundado em 1926, uma das mais importantes entidades negras de São Paulo até 1930. ${ }^{9}$ A Legião Negra, também

6 O Arquivo Público do Estado de São Paulo, órgão vinculado à Casa Civil, colocou em seu site 23 títulos de jornais e revistas da chamada Imprensa Negra brasileira. Os jornais disponíveis para acesso online no site <http://www. arquivoestado.sp.gov.br/jornais> são: O Alfinete (1918-1921), Alvorada (1948), Auriverde (1928), O Bandeirante (1918-1919), Chibata (1932), O Clarim (1924), O Clarim d'alvorada (1929-1940), Cruzada cultural (1950-1966), Elite (1924), Getulino (1916-1923), Hífen (1960), O Kosmos (1924-1925), A Liberdade (1919-1920), Monarquia (1961), O Novo Horizonte (1946-1954), O Patrocínio (1928-1930), Progresso (1930), A Rua (1916), Tribuna negra (1935), A voz da raça (1933-1937), O Xauter (1916). As Revistas: Quilombo (1950) e Senzala (1946) estão no site <http://www.arquivoestado.sp.gov.br/a_revistas> . Acesso em: agosto de 2013.

7 Além da Frente Negra Brasileira, outras entidades floresceram com o propósito de promover a integração do negro à sociedade mais abrangente, dentre as quais se destacam o Clube Negro de Cultura Social (1932) e a Frente Negra Socialista (1932), em São Paulo; a Sociedade Flor do Abacate, no Rio de Janeiro, a Legião Negra (1934), em Uberlândia/MG, e a Sociedade Henrique Dias (1937), em Salvador (Domingues, 2007a, p.107).

8 Foi um partido político que previa combater o racismo e também lutar por melhores condições de trabalho e saúde. Foi o primeiro partido político formado e idealizado por negros, tendo sido fechado em 1935 por Getúlio Vargas. Foi talvez a frente mais importante que o movimento negro já teve, englobando muitos participantes de outros movimentos menores e contando com filiais em outros estados brasileiros. Desse modo, a Frente Negra Brasileira alcançou cerca de 20 mil participantes os quais eram beneficiados com o acesso a grupos musicais e teatrais, de futebol, serviços médicos e formação em política, o qual contava com a força do jornal A voz da raça. As mulheres tinham um peso significativo na participação (Domingues, 2007a, p.103). Andrews (1991, p.34) informa que A Frente Negra aliava com o integralismo, e até adotou como lema "pela família, pela pátria e por Deus". A voz da raça relatava em termos altamente positivos os êxitos do nazismo e do fascismo em instalar disciplina e patriotismo em seus povos.

9 O Centro Cívico Palmares foi a mais importante, quer pela proposta de elevação política, moral e cultural, quer pelo grau de organização e capacidade de penetração na comunidade negra. O grupo estava disposto a encampar a luta contra o "preconceito de cor" em uma perspectiva mais política, sem recorrer às atividades recreativas, como os bailes dançantes. Em 1929, o Centro Cívico Palmares foi praticamente dissolvido (Domingues, 2007a, p.148). 
conhecida como Pérolas Negras, surgiu no mesmo ano da criação da FNB, em decorrência das divergências de posicionamento político frente à adesão à Revolução Constitucionalista, em São Paulo. Uns, acreditam na revolução e a viam como uma luta também do povo negro. Outros consideravam apenas a possibilidade de receber algum tipo de remuneração nas frentes de batalha (Domingues, 2003). No final de 87 dias e com o fim da revolução, a Legião Negra passou a atuar como sociedade civil em prol das lutas da população negra. Em 1937, com a instauração do Estado Novo, a Legião Negra, a Frente Negra Brasileira (FNB), assim como as demais organizações políticas, foram extintas (Domingues, 2007a, p.105).

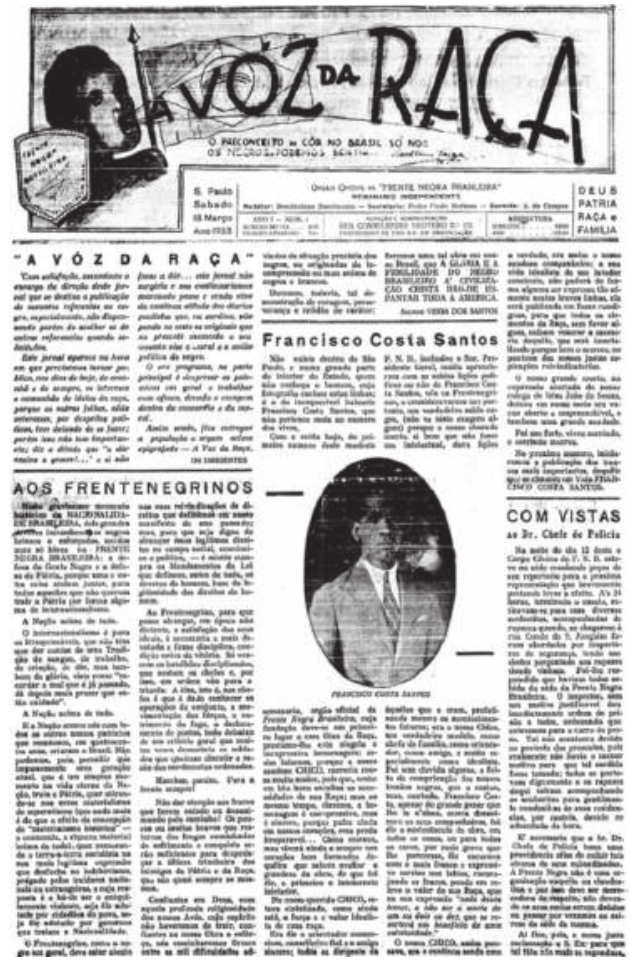

Figura 1: A voz da raça, São Paulo, 18 de março de 1933

Fonte: Arquivo do Estado de São Paulo. 
E' assim que se confirma a victoria do esforco de um pugilo de bravos luctadores! A Casa do Negro. será a crystalisação perfeita de uma idéa que se torna realidade. A sua instalaça representa o alvorecer de uma época promissora. E' uma conquista que deve ser analysada, porem, deve merecer os aplausos e 0 apoio de toda a colleetividade negra.
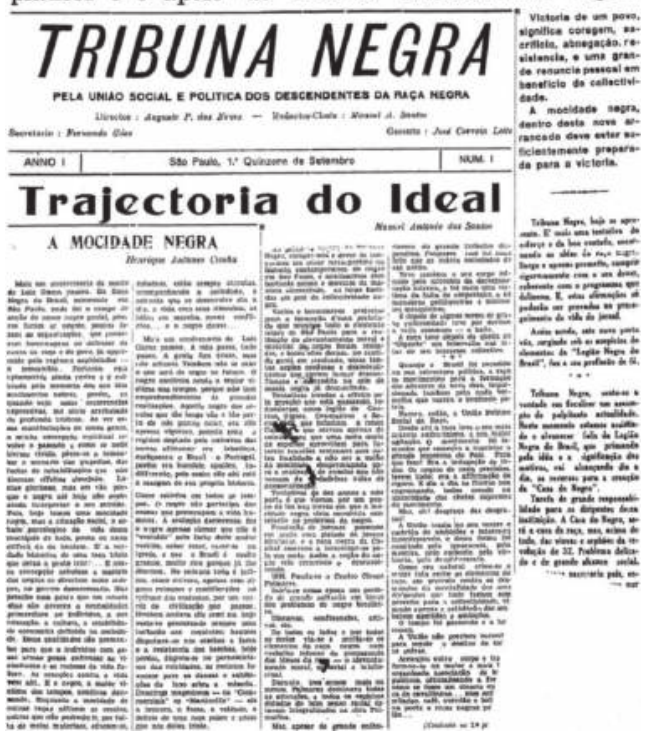

Figura 2: Tribuna negra. Ano I, n.I, São Paulo, 1935

Fonte: Arquivo do Estado de São Paulo.

Com o fim do Estado Novo, em 1945, ocorreu um "Renascimento Negro" (Silva, 2003, p.219). O movimento retornou com maiores reivindicações, com o surgimento de grupos de discussão e ações contra a discriminação racial e o racismo, e com novas associações com grande poder de agrupamento como: a Cruzada Social e Cultural do Preto Brasileiro, o Centro de Cultura Luiz Gama, a Frente Negra Trabalhista, a Associação do Negro Brasileiro (ANB). No Rio de Janeiro, o Grupo de Afoxé Associação Recreativa Filhos de Gandhi, a União dos Homens de Cor (UHC), a União Cultural dos Homens de Cor, o Teatro Popular Brasileiro (TPB), o Renascença Clube e a Orquestra 
Afro-Brasileira, composta por dezoito músicos. ${ }^{10}$ No mesmo ano em que termina o Estado Novo, ocorre a Convenção Nacional do Negro, em São Paulo (Andrews, 1971, p.33). Ainda em 1944, no Rio de Janeiro, foi fundado o Teatro Experimental do Negro (TEN), sob a liderança de Abdias do Nascimento, com o objetivo de:

Resgatar, no Brasil, os valores da pessoa humana e da cultura negro-africana, degradados e negados por uma sociedade dominante que, desde os tempos da colônia, portava a bagagem mental de sua formação metropolitana europeia, imbuída de conceitos pseudocientíficos sobre a inferioridade da raça negra. Propunha-se o TEN a trabalhar pela valorização social do negro no Brasil, através da educação, da cultura e da arte. (Nascimento, 2004, p.210)

O TEN criticava os estudos afro-brasileiros, taxando-os de alienantes. Os próprios negros deveriam refletir sobre sua situação. Seguindo este propósito, o TEN alfabetizava seus participantes, um grupo heterogêneo de empregadas domésticas, funcionários públicos, profissionais liberais, operários e pessoas sem profissão definida, projeto que contou, na sua primeira edição, com 600 inscrições; e promovia encontros e discussões com a presença de palestrantes de diversas áreas do conhecimento. Após seis meses de intensa preparação, artistas do TEN estavam prontos para entrar em cena.

No dia 8 de maio de 1945, no palco do Teatro Municipal do Rio de Janeiro, o TEN encenou O Imperador Jones, de autoria do dramaturgo anarquista e socialista norte-americano, Eugene O'Neill. A apresentação no Teatro Municipal, onde

10 A União dos Homens de Cor foi fundada em Porto Alegre em 1943. Cinco anos mais tarde ramificou-se por mais dez estados da Federação (Silva, 2003, p.215). 
"antes nunca pisara um negro como intérprete ou como público" (Nascimento, 2004, p.210), só foi possível pela autorização direta do então presidente Getúlio Vargas, que tomara conhecimento da denúncia feita por Abdias, acusando o Teatro Municipal de "fortaleza do racismo" (Douxami, 2001, p.318).

Além da atividade teatral, o TEN organizou a Convenção Nacional do Negro em São Paulo (1945) e no Rio de Janeiro (1946). Na ocasião, o grupo redigiu um documento que encaminhou à Constituinte de 1946, com a proposta de inclusão da discriminação racial como crime de lesa-pátria. De acordo com Abdias do Nascimento, "pouco conhecidos são esses antecedentes da lei antidiscriminatória que ficou conhecida, posteriormente, como Lei Afonso Arinos" (Nascimento, 2004, p.223).

Em janeiro de 1950, o TEN realizou no Rio de Janeiro o I Congresso do Negro Brasileiro. Os trabalhos apresentados foram reunidos no livro $O$ negro revoltado, organizado por Abdias Nascimento (1968). Outros eventos como Concurso do Cristo Negro, realizado no Rio de Janeiro em 1955, e os concursos de beleza Rainha das mulatas e Boneca de pixe utilizados como instrumentos pedagógicos para valorização da beleza negra também foram apoiados e organizados pelo TEN. O grupo continuou em cena até o fim dos anos de 1960, mas com o exílio de Abdias do Nascimento para os Estados Unidos, em 1968, foi praticamente dissipado.

\section{A afirmação da negritude}

Desde os anos de 1950, a intelectualidade vinha colocando em xeque a crença da democracia racial, argumentando que o Brasil se caracteriza pela exclusão racial. No final da década de 1970, passando por toda a década de 1980, período em que "novos personagens entram em cena" (Sader, 2001), diversos 
movimentos sociais, no exercício da democracia, assumiram a determinação de se tornarem sujeitos da história. O movimento negro, além de marcar posição contra a ditadura, assumiu para si a noção de raça, seja nos termos "comunidade negra", "identidade negra", ou "povo negro", enfim, assumiu radicalmente o designativo "raça negra".

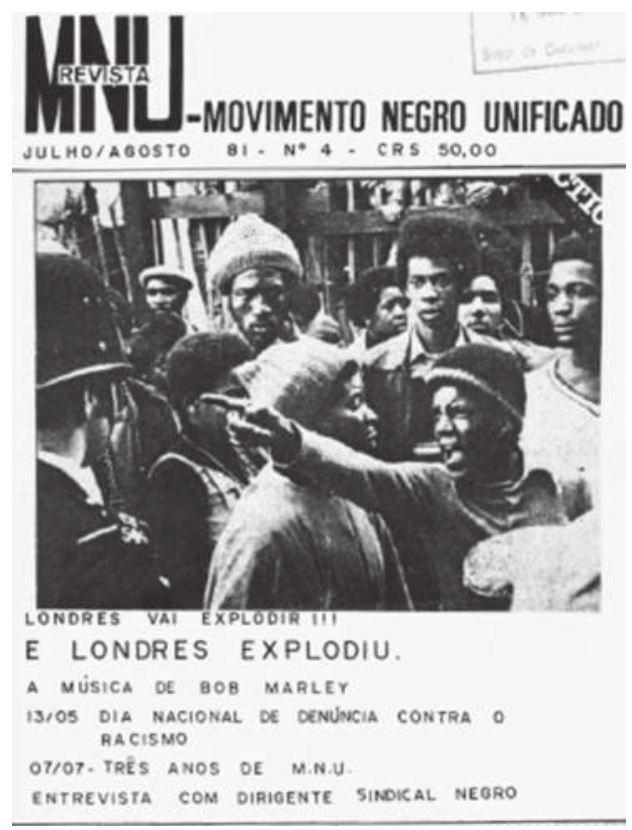

Figura 3: Capa da revista do Movimento Negro Unificado (MNU), n.4, p.1, jul-ago. 1981

Fonte: <http://www.cpvsp.org.br/upload/periodicos/pdf/PMNEUSP071981004.pdf>. Acesso em: ago. 2013.

Depois do exílio de Abdias, o movimento negro fragmentou-se, mas não se extinguiu. As notícias dos diversos eventos antidiscriminatórios nos Estados Unidos faziam ressonância no Brasil. Em São Paulo, em 1971, criou-se o Centro de Cultura e Arte Negra (Cecan), uma das primeiras entidades negras a trabalhar a noção da negritude, tendo o teatro como instrumento 
de conscientização e de denúncia, além de educação e cultura. ${ }^{11}$ A imprensa negra, embora timidamente, deu sinais de vida, com os jornais Árvore das palavras (1974) e O quadro (1974), em São Paulo; Biluga (1974), em São Caetano/SP; e Nagô (1975), em São Carlos/SP. Em Porto Alegre, organizou-se o Grupo Palmares (1971), o primeiro a defender a substituição das comemorações do "13 de Maio" pelo "20 de Novembro", dia da morte de Zumbi dos Palmares em 1695. No Rio de Janeiro, explodiu, no interior da juventude negra, o movimento Soul, depois batizado de Black Rio, e foi fundado o Instituto de Pesquisa das Culturas Negras (IPCN), em 1976 (Domingues, 2007a, p.112). ${ }^{12}$

Em 1978, no clima das manifestações estudantis e sindicais, foi fundado o Movimento Negro Unificado (MNU), considerado um marco na formação do Movimento Negro contemporâneo. No dia 18 de junho, o MNU, em reunião em São Paulo com outras organizações - Grupo Afro-Latino América, Câmara do Comércio Afro-Brasileiro, Jornal Abertura, Jornal Capoeira, Grupo de Atletas e Grupo de Artistas Negros - tirou as diretrizes para a sua primeira atividade: o ato público, de duas mil pessoas, realizado no dia 7 de julho em repúdio a discriminação racial sofrida por quatro jovens no Clube de Regatas do Tietê e pela morte por tortura policial do jovem negro Robson Silveira da Luz, realizado na escadaria do Teatro Municipal de São Paulo.

Alguns meses após o ato público, o MNU redigiu uma "carta de princípios", definindo "o que é ser negro no Brasil" e suas principais reinvindicações as quais, mais tarde, vão constar da pauta das políticas afirmativas direcionadas à população negra: valorização da memória e da cultura, cotas universitárias e de emprego, o ensino da História da África e reavaliação do papel do negro na História do Brasil, a posse das terras quilombolas.

11 Sobre o Centro de Cultura e Arte Negra, ver Silva (2012).

12 Para maiores informações sobre esse período do movimento negro consultar Monteiro (1999). 
Nós, membros da população negra - entendendo como negro todo aquele que possui na cor da pele, no rosto ou nos cabelos, sinais característicos dessa raça - reunidos em Assembleia [...] resolvemos juntar nossas forças e lutar pela defesa do povo negro em todos os aspectos. Por mais oportunidades de emprego, melhor assistência à saúde, à educação, à habitação, pela reavaliação do papel do negro na história do Brasil, valorização da cultura negra, extinção de toda forma de perseguição [...] Pela libertação do povo negro! (Carta de princípios do MNU, 1978, apud Pereira, 2013, p.99)

Na segunda assembleia do MNU, no dia 4 de novembro de 1978, na cidade de Salvador, o dia 20 de novembro ficou estabelecido como "Dia da Consciência Negra", atualmente feriado em mais de 200 municípios de todo país (Pereira, 2013, p.99). Com a comemoração do centenário da Abolição, em 1988, enquanto a elite política, econômica e intelectual festejava na mídia o país "miscigenado", o país da "democracia racial”, o movimento negro negou-se a comemorar o dia 13 de maio. A recusa da memória oficial ultrapassou as fronteiras do próprio movimento e ganhou as ruas e a voz de uma parcela significativa da população através das músicas nas escolas de samba. Neste mesmo ano, a escola de samba Vila Isabel, do Rio de Janeiro, foi campeã do carnaval com o samba "Kizomba, festa da raça", cujos primeiros versos eram: "valeu Zumbi, o grito forte dos Palmares, que correu terras, céus e mares, influenciando a abolição" (Pereira, 2013, p.18).

Dos protestos e comemorações do centenário da Abolição, duas reivindicações viraram leis e entraram para a Constituição de 1988: a criminalização do racismo (Artigo 5ํ) e o reconhecimento de propriedade das terras de remanescentes de quilombos (Artigo 68 do Ato das Disposições Constitucionais Transitórias).

No mesmo ano, a Igreja Católica lançou a Campanha da Fraternidade: "A Fraternidade e o Negro: Ouvi o clamor desse povo” (Amado, 1989, p.75). A Campanha da Fraternidade (1988) 
em prol do povo negro fora resultado do grande número de dirigentes negros nas organizações de base da Igreja Católica, nos encontros, na articulação dos negros no movimento União e Consciência Negra, no grupo dos agentes de pastoral negros e na conversão de importantes setores da Igreja para as lutas dos mais pobres. Daí surge a Pastoral Afro-Brasileira e a Associação de Padres Negros (APNs). Nessa ocasião, a Igreja reconhece a situação de marginalização em que se encontra a comunidade negra e também reconhece seu envolvimento na história da escravidão brasileira. O tema da Campanha da Fraternidade (1988) tocou no problema central do cotidiano das camadas populares, teve acolhida calorosa em certas áreas, suscitou perplexidade e mal-estar em outras, foi marginalizado em algumas paróquias (Amado, 1989, p.76).

No dia 12 de maio de 1988, no arco da Lapa, no Rio de Janeiro, 300 artistas negros apresentaram a Missa dos Quilombos, celebrada por D. Pedro Casaldáliga e Pedro Tierra, e com a música de Milton Nascimento que, em 1982, fora proibida pela Congregação para o Culto Divino. Nesse mesmo dia, o Exército reprimiu a passeata de dez mil negros. Os discursos no Congresso Nacional foram vaiados, e muitas das comemorações oficiais do dia 13 de Maio foram boicotadas pela comunidade negra que insistia em celebrar o 20 de novembro, dia da morte de Zumbi, o último chefe do Quilombo dos Palmares, como o Dia da Consciência Negra (Amado, 1989, p.76).

Em 1995, ocorreu a Marcha Zumbi dos Palmares em Brasília, em homenagem aos 300 anos da morte de Zumbi dos Palmares. Este evento funcionou como catalisador das discussões sobre políticas afirmativas e da movimentação da sociedade civil em torno da questão racial. A Marcha foi um "ato de indignação e protesto contra as condições subumanas que vivem os negros no país em função da exclusão e discriminação racial" (Duarte, 2013, p.68). Desmoronava-se o mito da democracia racial. 
Em 2001, ocorreu em Durban, África do Sul, a Conferência Mundial das Nações Unidas contra o Racismo, a Xenofobia e a Intolerância Correlata, com o objetivo de definir estratégias contra o racismo e o preconceito. A Conferência contou com a presença de 170 países, que se mobilizaram internamente para preparar documentos e propostas de ações. Em 8 de julho de 2001, dias antes da conferência de Durban, acontecera a Conferência Nacional contra o Racismo e a Intolerância, na cidade do Rio de Janeiro, ocasião em que se elaborou a Carta do Rio (2001), defendendo veementemente a necessidade de políticas afirmativas formuladas e executadas pelos poderes públicos articulados à sociedade civil, para o combate ao racismo, à intolerância e à reprodução de práticas e políticas socialmente discriminatórias.

\section{A criminalização do racismo}

O reconhecimento institucional do preconceito racial no Brasil foi explicitado na sua forma jurídica pela primeira vez na Constituição de 1946, no Capítulo II, que trata dos Direitos e Garantias Individuais: "Não será tolerada propaganda de guerra, de processos violentos para subverter a ordem política e social, ou de preconceitos de raça ou de classe". A lei n.1390 de 3 de julho de 1951, conhecida como Lei Afonso Arinos, foi a primeira a considerar como contravenção penal, ou seja, infração de menor grau ofensivo, qualquer prática de discriminação ou preconceito racial no país.

Embora a Lei Afonso Arinos tenha sido considerada "sem clamor público", incapaz de transformar a mentalidade racista de um país que até então, pelo menos juridicamente, acreditava no mito da democracia racial brasileira e na não gravidade dos preconceitos raciais quando comparado aos Estados Unidos ou a países da Europa, atuou como propulsora de um debate, desvelando um problema social não discutido no âmbito jurídico 
e de políticas públicas (Grin; Maio, 2013, p.35). Em 1985, o racismo como contravenção penal foi transformado em crime pela Lei Caó (7437/85). A Constituição de 1988 tornou a prática do racismo "crime inafiançável e imprescritível, sujeito à pena de reclusão, nos termos da lei” (Brasil, 1988, tit.II, cap.I, XLII, art.5). Em 5 de janeiro de 1989, entrou em vigor a lei $n$. 7716/89, segunda versão da Lei Caó, que regulamenta o inciso constitucional, criminalizando práticas específicas vinculadas ao racismo. Foram elencadas situações que, motivadas por preconceito de raça/cor, etnia, religião ou procedência nacional, seriam consideradas crimes de discriminação racial (Brasil, 1997).

A redação da lei 7716/89 foi alterada pela lei 9459/97, de autoria do então deputado federal Paulo Paim (PT-RS), prevendo pena para o crime de injúria quando envolve elementos referentes à raça, cor, etnia, religião ou origem (Brasil, 1940, art.140, §3). A “injúria qualificada”, presente no artigo 140 do Código Penal Brasileiro, é uma das manifestações mais recorrentes de racismo. Ocorre através de palavras ofensivas e agressão verbal, ao "atribuir qualidades negativas que ofendam a dignidade" baseadas no menosprezo à raça/cor/origem/etnia e características fenotípicas, como textura do cabelo, formato do nariz, boca entre outros. O inciso 2 da lei 7716/89 prevê o seguinte:

Ficará sujeito às penas de multa e prestação de serviços à comunidade, incluindo atividades de promoção da igualdade racial, quem, em anúncios ou qualquer outra forma de recrutamento de trabalhadores, exigir aspectos de aparência próprios de raça ou etnia para emprego cujas atividades não justifiquem essas exigências. ${ }^{13}$

13 Outras leis que apresentaram garantias importantes para a população negra encontram-se no site: <http://portal.mj.gov.br/sedh/ct/legis_intern/ddh_ bib_inter_universal.htm>. Acesso em: 6 ago. 2013. 


\section{A discriminação positiva}

\section{O Estatuto da Igualdade Racial e a criação da Secretaria de Políticas de Promoção da Igualdade Racial (Seppir)}

No dia 21 de março de 2003, dia Internacional Contra a Discriminação Racial, ${ }^{14}$ criou-se, no Brasil, a Secretaria de Políticas de Promoção da Igualdade Racial (Seppir), ${ }^{15}$ com as seguintes funções: formular, coordenar e articular políticas afirmativas para promover a igualdade racial; proteger os direitos de indivíduos e grupos, com ênfase na população negra; acompanhar a implementação da legislação de ação afirmativa e de políticas públicas que visem o cumprimento de acordos, convenções e outros instrumentos congêneres assinados pelo Brasil, nos aspectos relativos à promoção da igualdade e do combate à discriminação racial ou étnica.

Também em 2003 foi aprovado o Estatuto da Igualdade Racial "em defesa dos que sofrem preconceito ou discriminação em função de sua etnia, raça e/ou cor" (Brasil, 2003, p.27), e em prol de ações afirmativas. ${ }^{16}$ Em países onde este tipo de ação já

14 Esta data foi instituída pela Organização das Nações Unidas (ONU), em memória do Massacre de Sharperville. Em 21 de março de 1960, 20 mil negros protestavam na cidade de Joanesburgo, África do Sul, contra a lei do passe, que os obrigava a andar com cartões de identificação especificando os locais em que podiam transitar. Mesmo sendo uma manifestação pacífica, o exército atirou sobre os manifestantes. Foram contabilizados 69 mortos e 186 feridos (Brasil, 2013).

15 Pela lei provisória n.111 de 21 de março de 2003, convertida na Lei 10978.

16 Utilizada pela primeira vez pelo então presidente dos Estados Unidos J. F. Kennedy, em 1963, a expressão política afirmativa significa: "um conjunto de políticas públicas e privadas de caráter compulsório, facultativo ou voluntário, concebidas com vistas ao combate da discriminação de raça, gênero etc., bem como para corrigir os efeitos presentes da discriminação praticada no passado" (Domingues, 2005, p. 166). 
havia sido implantado, como Índia, Estados Unidos, Canadá, Nova Zelândia, Alemanha, Inglaterra e também no Brasil, elas continham o propósito de:

Oferecer aos grupos discriminados e excluídos um tratamento diferenciado para compensar as desvantagens devidas à sua situação de vítimas do racismo e de outras formas de discriminação. Daí as terminologias de "equal oportunity policies", ação afirmativa, ação positiva, discriminação positiva ou políticas compensatórias. (Munanga, 2003, p.1)

As ações afirmativas, também chamadas de discriminação positiva, segundo o filósofo Nigel Warburton (2007, p.121122), significam:

Recrutar ativamente pessoas de grupos previamente em situação de desvantagem. Por outras palavras, a discriminação positiva trata deliberadamente os candidatos de forma desigual, favorecendo pessoas de grupos que tenham sido vítimas habituais de discriminação. O objetivo de tratar as pessoas desta forma desigual é acelerar o processo de tornar a sociedade mais igualitária, acabando não apenas com desequilíbrios existentes em certas profissões, mas proporcionando também modelos que possam ser seguidos e respeitados pelos jovens dos grupos tradicionalmente menos respeitados. [...] A discriminação positiva é apenas uma medida temporária, até que a percentagem de membros do grupo tradicionalmente excluído reflita mais ou menos a percentagem de membros deste grupo na população em geral. Em alguns países é ilegal; noutros, é obrigatória.

No Brasil, de acordo com Estatuto da Igualdade Racial (Brasil, 2003), um sistema de cotas para o ingresso de minorias no ensino superior corrigiria os efeitos nocivos do preconceito sobre 
as populações discriminadas e minimizaria a desigualdade de ocupação dos espaços institucionais e educacionais entre brancos e negros. Em defesa do Estatuto, o senador Paulo Paim afirmou que o Brasil estava muito longe de ser um país onde todos fossem iguais e, para isso, os "círculos fechados da elite precisariam ser quebrados” (Brasil, 2003, p.28) Na introdução do Estatuto, foi apresentado o seguinte argumento para a adoção do sistema de cotas:

Sabemos que o sistema de cotas sofrerá profundas discussões, assim como aconteceu nos Estados Unidos onde as argumentações vão desde a temporalidade do sistema até conceitos de livre promoção do indivíduo, de sua liberdade, vontade e competência, transformando assim o estado de direito em um administrador de interesses de grupos e corporações. Essa justificativa para não adotarmos as ações afirmativas no Brasil poderiam ter consistência se todos tivessem as mesmas oportunidades. Na realidade a sociedade não é igual e tratar pessoas de fato desiguais como iguais só amplia a distância inicial entre elas, mascarando e justificando a perpetuação de iniquidades. Além do sistema de cotas nas universidades e no trabalho, queremos que todos os livros referentes à participação do negro no Brasil sejam reescritos, a exemplo do que Nelson Mandela fez na África do Sul. (Brasil, 2003, p.28)

O Estatuto previa cota mínima de $20 \%$ para a população afro-brasileira no preenchimento das vagas relativas aos concursos para cargos públicos e cursos de graduação em todas as instituições de educação superior do território nacional. Previu ainda que as empresas privadas com mais de 20 empregados mantivessem uma cota de no mínimo $20 \%$ para trabalhadores afro-brasileiros (Brasil, 2003, p.23). Em 2006, foi redigido um novo Estatuto da Igualdade Racial, também de autoria do senador Paulo Paim. As diretrizes do estatuto anterior foram 
reafirmadas e a institucionalização das políticas afirmativas foi respaldada pela concepção multiculturalista e pelo antirracismo diferencialista. $\mathrm{O}$ direito à terra dos remanescentes de quilombos, a obrigatoriedade da disciplina História da África ${ }^{17}$ no ensino fundamental e médio e as cotas para o ingresso de estudantes negros no ensino superior foram as principais frentes de atuação das políticas afirmativas promovida pelo Estado brasileiro. ${ }^{18}$

\section{As terras quilombolas}

Em 1984, a Serra da Barriga, local do antigo Quilombo dos Palmares, foi elevada à categoria de Patrimônio Histórico Nacional. A partir deste acontecimento, intensificou-se a luta pelo reconhecimento das comunidades quilombolas com direito à posse da terra. Comunidades quilombolas são grupos "étnicos-raciais, segundo critérios de autoatribuição, com trajetória histórica própria, dotados de relações raciais específicas, com presunção de ancestralidade negra relacionada com a resistência à opressão histórica sofrida" (Brasil, 2003).$^{19}$ A Constituição de 1988 tinha já assegurado o direito à propriedade de terra às propriedades quilombolas e, neste mesmo ano, sob o calor das comemorações do Centenário da Abolição, fora criada a Fun-

17 O Art. 20 do Estatuto da Igualdade Racial (2003) prevê: "A disciplina 'História Geral da África e do Negro no Brasil' integrará obrigatoriamente o currículo do ensino fundamental e médio, público e privado".

18 Em 1996 ocorreu também o Seminário Ações afirmativas: estratégias discriminatórias? no Instituto de Pesquisa Econômica (Ipea) e em seguida o Seminário Internacional Multiculturalismo e Racismo: o papel da ação afirmativa no estados democráticos contemporâneos, promovido pelo Ministério da Justiça em Brasília (Moehlecke, 2002, p. 207).

$19 \mathrm{O}$ autorreconhecimento das comunidades quilombolas foi legalmente amparado pela Convenção 169 da Organização Internacional do Trabalho (OIT) e inserido à legislação brasileira pelos Decretos 143/2002 e 5051/2004. A regulamentação do procedimento para identificação, reconhecimento, demarcação e titulação das terras ocupadas pelos quilombolas é feita pelo decreto $\mathrm{n}$. $4887 / 2003$ de 20 de novembro de 2003, especificamente pelo artigo 68. 
dação Cultural Palmares (FCP), vinculada ao Ministério da Cultura, com o objetivo de promover os valores culturais, sociais e econômicos decorrentes da influência negra na formação da sociedade brasileira, recebendo como função desenvolver ações que propiciem:

a) O estímulo, a valorização e o desenvolvimento da cultura e do patrimônio afro-brasileiro;

b) O desenvolvimento de ações de inclusão e sustentabilidade das comunidades remanescentes de quilombos;

c) A realização de pesquisas, estudos e levantamento de dados e informações sobre a população afrodescendente e, mais especificamente, sobre a cultura e o patrimônio afro-brasileiro (Brasil, 1988).

Além destas funções, a Fundação Cultural Palmares passou também a ser a responsável pela emissão da certidão de reconhecimento das comunidades quilombolas. Segundo a FCP, estima-se que em todo o país existam 2.187 comunidades remanescentes de quilombos com certidão de reconhecimento já expedida; há 270 processos abertos, até a data de 6 de junho de 2013 e mais 556 comunidades identificadas como remanescente de quilombos, que ainda não reivindicaram o reconhecimento. ${ }^{20}$ Em 2003, pelo decreto n.4883, a responsabilidade da delimitação, regularização e titulação das terras das comunidades quilombolas passou para o Instituto Nacional de Colonização e Reforma Agrária (Incra). Mas o processo de regularização da terra deve ser encaminhado ao Incra pelas comunidades interessadas, após a emissão da certidão de registro no Cadastro Geral de Remanescente de Comunidades de Quilombos pela Fundação Cultural Palmares. O título de propriedade emitido

20 As listas completas podem ser acessadas no site da Fundação Cultural Palmares (2013). Disponível em: <http://www.palmares.gov.br> . Acesso em: ago. 2013. 
às comunidades quilombolas é coletivo, pró-indiviso e em nome da associação dos moradores. As terras não podem ser vendidas, leiloadas ou desmembradas (Brasil, 2011).

O Estatuto da Igualdade Racial (2003-2006) prevê o direito à propriedade definitiva das terras ocupadas pelos remanescentes das comunidades dos quilombos, reiterando a necessidade de compensação econômica e de titularidade da terra aos descendentes dos quilombolas para reparar as "injustiças sofridas". Em 12 de março de 2004, foi lançado o Programa Brasil Quilombola (PBQ), em parceria com a Seppir e com a FCP. O objetivo do programa foi consolidar as políticas de Estado para as áreas quilombolas. Como desdobramento do projeto, foi criada a Agenda Social Quilombola (Decreto 6261/2007), que tem por objetivos: garantir o acesso a terra; ações de saúde e educação; construção de moradias, eletrificação, recuperação ambiental; incentivo ao desenvolvimento local; pleno atendimento às famílias quilombolas pelos programas sociais como o Bolsa Família; e medidas de preservação e promoção das manifestações culturais quilombolas (Brasil, 2013).

Desde então, a Seppir considera que houve um notável crescimento das demandas quilombolas, refletidas nas ações orçamentárias. O Plano Brasil Maior - Plano Plurianual 2012-2015 (PPA) -, no item 2034 sobre Enfrentamento ao Racismo e Promoção da Igualdade Racial, prevê o investimento de R\$313 milhões na promoção de ações afirmativas para a população, para a regularização fundiária e para manutenção de serviços e programas voltados especificamente para as populações quilombolas (Brasil, 2012a).

\section{As cotas universitárias}

A ação afirmativa mais polêmica, e de maior impacto midiático e acadêmico, foi a adoção das cotas para estudantes negros 
entrarem em universidades brasileiras. Esta reivindicação, no Brasil, vinha de longa data. Em 1968, técnicos do Ministério do Trabalho defenderam a criação de medidas que obrigassem as empresas a contratar "pessoas de cor" (Moehlecke, 2002, p.199), em porcentagens variáveis de acordo com a demanda e setor de trabalho. A proposta não chegou nem a projeto de lei. De acordo com o Instituto de Pesquisas e Estudos Afro-Brasileiros (Instituto de Pesquisa e Estudos Afro-brasileiros, 2013), a primeira formulação de um projeto de lei de ações afirmativas ocorreu em 1980, de autoria do então deputado federal pelo Partido Democrático Trabalhista (PDT), Abdias do Nascimento. O projeto, que recebeu o n.1332-83, defendia a isonomia social do negro em relação aos demais segmentos étnicos da população brasileira, através de reserva de $20 \%$ de vagas para mulheres negras e 20\% para homens negros em concursos públicos; equivalência salarial entre negros e brancos; bolsas de estudos para estudantes negros; alteração dos currículos escolares visando à inserção da imagem positiva dos afro-brasileiros na literatura didática e paradidática; obrigatoriedade do ensino das civilizações africanas e do africano no Brasil (Brasil, 1983).

O projeto tramitou durante alguns anos pelo Plenário sem ser aprovado. Em 1995, representantes da Marcha Zumbi dos Palmares contra o racismo, pela cidadania e pela vida redigiram uma proposta para a criação do Programa de Superação do Racismo e Desigualdade Social, com a seguinte pauta de atuação: incentivos fiscais a empresas que adotassem programas de igualdade racial; incorporação do quesito cor em diversos sistemas de informação; programar a Convenção sobre Eliminação da Discriminação Racial no Ensino; conceder bolsas para adolescentes negros de baixa renda, para o acesso e conclusão do primeiro e segundo graus de ensino; desenvolvimento de ações afirmativas para o acesso dos negros aos cursos profissionalizantes, à universidade e às áreas de tecnologia de ponta; assegurar a repre- 
sentação proporcional dos grupos étnicos raciais nas campanhas de comunicação do governo e de entidades que com ele mantivessem relações econômicas e políticas (Marcha Zumbi, 1996).

$\mathrm{O}$ documento foi entregue ao governo federal no dia 20 de novembro de 1995 (Dia da Consciência Negra e data do tricentenário da morte de Zumbi). Nesta mesma data o governo instituiu o Grupo de Trabalho Interministerial (GTI) que atuaria na promoção e desenvolvimento da população negra. No ano seguinte, no dia 13 de maio, foi lançado o Programa Nacional dos Direitos Humanos (PNDH I), que estabelecia o desenvolvimento de ações afirmativas para o acesso dos negros a cursos profissionalizantes, à universidade e às áreas tecnológicas de ponta, além de ações compensatórias que promovessem social e economicamente a comunidade negra, apoiando iniciativas privadas que promovessem a "discriminação positiva” (Brasil, 1996, p.30).

Para seguirmos o percurso que culminou na institucionalização das políticas afirmativas através da "discriminação positiva", é importante fazer menção mais uma vez à Conferência Mundial de Combate ao Racismo, de Duban, em 2001. No dia 7 de setembro, aprovou-se, na Conferência, uma declaração e um plano de ação, direcionados para a problemática do racismo e intolerância no mundo. Entretanto, três dias após a publicação dos documentos, aconteceu o ataque ao World Trade Center, repercutindo sobre a opinião pública no que dizia respeito o Plano de Ação de Durban, em defesa da tolerância e igualdade de direitos entre etnias, religiões e estilos de vida. Passado o choque inicial, os princípios norteadores da Conferência de Durban foram sendo assimilados positivamente, por diversos países, e impulsionaram políticas de combate à intolerância e ao racismo (Saboia; Porto, 2002, p.22).

Foi este o caso do Brasil que introduziu em sua pauta política a discussão sobre políticas afirmativas. Os preparativos e a participação de uma numerosa delegação em Durban possibi- 
litaram ampla e rica discussão sobre o racismo e a intolerância, contribuindo para elevar o

nível de conscientização da população sobre a realidade do racismo e seus efeitos. Esta parece ser a mais importante conquista da conferência para o Brasil: ter conseguido incluir o combate ao racismo como tarefa a ser levada a cabo pela sociedade brasileira. (Saboia; Porto, 2002, p.24)

Em 2002, com os intensos debates e pressões dos movimentos sociais, foi lançado o Programa Nacional dos Direitos $\mathrm{Hu}$ manos II (PNDH II) que continha praticamente as mesmas ações do PNDH I de 1996. O Ministério do Desenvolvimento Agrário e o Incra, em setembro de 2001, foram os primeiros órgãos federais a institucionalizar um programa de ações afirmativas: reservariam 45\% das vagas do quadro de funcionários para mulheres, negros e deficientes. Em 2002, foi estipulado que todas as empresas terceirizadas que prestassem serviços para estes órgãos deveriam reservar 20\% de suas vagas para negros. Desde então vários segmentos aderiram às cotas, especialmente as universidades públicas brasileiras. ${ }^{21}$

No dia 28 de abril de 2004, o então presidente Luís Inácio Lula da Silva encaminhou ao Congresso Nacional o Projeto de Lei n.3627/2004,22 prevendo cotas nas universidades púbicas federais de no mínimo $50 \%$ de suas vagas para estudantes que cursaram integralmente o ensino médio em escolas públicas; e dessa reserva de $50 \%$, parcelas devem ser definidas e destinadas

21 A lista completa das 107 universidades que já aderiram ao sistema de cotas está disponível em Fundação Cultural Palmares (2013).

22 Já havia 28 projetos na Câmara e 4 no Senado, versando sobre cotas em instituições federais de educação superior, para candidatos advindos das minorias étnicas e para grupos das camadas pobres da população (Pacheco; Silva, 2007, p.47). 
a negros e indígenas autodeclarados. ${ }^{23} \mathrm{O}$ projeto, finalmente, foi aprovado pela Lei n.12.711 (Brasil, 2012b), de 29 de agosto de 2012. As cotas a partir de então são prescritas em lei.

\section{O desafio}

Célia Maria Marinho de Azevedo (2004), historiadora com larga experiência de pesquisa sobre a população negra brasileira, lançou a seguinte questão diante das políticas raciais afirmativas: abolição do racismo ou direito à raça? Foi este o dilema que dividiu as opiniões de intelectuais, especialistas nas áreas de antropologia, história e sociologia. O dilema posto: talvez o sistema de cotas contribua para abolir o "racismo à brasileira", mas, poderá criar grupos raciais distintos, o que sempre esteve ausente da caracterização da nação. Ou seja, implantar políticas afirmativas raciais, processando a "discriminação positiva", não macularia, não desmancharia aquilo que foi a singularidade do Brasil, o país da mistura, do hibridismo, da antropofagia de Oswald de Andrade, da democracia racial de Gilberto Freyre? Fazer emergir a "discriminação positiva" trabalharia em prol de uma sociedade futura universalista ou desenharia identidades fronteiriças, competitivas, capitalistas? (Azevedo, 2004, p.24-25). Não estariam as políticas afirmativas criando um novo apartheid, incentivando o preconceito, produzindo situações permanentes de conflito étnico? (Durham, 2003, p.66). O reconhecimento de grupos raciais pela população a partir de uma política antirracista de Estado poderá ser desfeito pelo mesmo Estado quando um dia se chegar à conclusão que a "discrimina-

23 Os estudos para criação do PL 3627/04 foram feitos pelo Grupo de Trabalho Interministerial, com representantes do MEC e da Seppir. Reitores, entidades de classe dos professores, representações dos estudantes, além de entidades que desenvolvem cursos preparatórios para vestibulares voltados a afrodescendentes e carentes foram ouvidos (Pacheco; Silva, 2007, p.48). 
ção positiva" já surtiu o efeito desejado? (Azevedo, 2004, p.25). Ações afirmativas implicam, evidentemente, imaginar o Brasil composto não de infinitas misturas, mas de grupos estanques: os que têm e os que não têm direito à ação afirmativa, no caso em questão, negros e brancos (Maggie; Fry, 2004, p.68).

Entre os intelectuais que pronunciaram-se - por meio de artigos, textos, conferências ou intervenções nos veículos de comunicação - analisando e ponderando razões para, no mínimo, questionar, senão rejeitar, a reserva de cotas raciais para o ingresso nas universidades públicas, podemos citar: os antropólogos Peter Fry (UFRJ) e Ricardo Ventura Santos (UFRJ e Fundação Oswaldo Cruz), as antropólogas Yvonne Maggie (UFRJ), Eunice Durham (USP) e Lilia Schwarcz (USP), o cientista político Marcos Chor Maio (Fundação Oswaldo Cruz), as historiadoras Célia Maria Marinho de Azevedo (Unicamp) e Mônica Grin (UFRJ), o historiador Manolo Fiorentino (UFRJ).

De modo geral estes intelectuais argumentam que a política de cotas não trará mudanças efetivas. O que se deve atacar são as estruturas profundas da sociedade que promovem a desigualdade. A raiz do problema está na educação básica. Afirma-se, principalmente, que as políticas de cotas para negros racializa a nação, que até hoje tem se constituído em um país de legislação a-racial, instituindo o negro como figura jurídica. Em vez de se ignorar a raça como critério de classificação e de concessão de direitos, o Estado entroniza-a como forma de definição social, provocando a divisão do país, como argumenta Peter Fry (2003):

Todos nós gostaríamos de ver as universidades públicas cada vez mais multicoloridas (as privadas já são). Também acredito que a maioria quer que o Brasil elimine o racismo de tal jeito que a discriminação racial e o medo dela deixem de ferir tanto. Mas a "solução" das cotas vai aumentar os problemas e não diminuí-los. Alguém realmente acredita que é possível corrigir as desigualdades 
raciais grosseiras a custo zero aos cofres públicos? O verdadeiro custo será a consolidação do racialismo, não o fim do racismo.

Demarcando essa posição contrária à política de cotas, no dia 29 de junho de 2006, foi entregue ao então presidente do Senado brasileiro o manifesto "Todos têm direitos iguais na República democrática" (Carta Pública ao Congresso Nacional, 2006) assinado por 114 pessoas, ${ }^{24}$ entre as quais intelectuais, artistas e militantes do Movimento Negro Socialista (MNS). ${ }^{25} \mathrm{O}$ manifesto afirma que a política de cotas e o Estatuto da Igualdade Racial implantariam uma classificação racial oficial nos cidadãos brasileiros, criando privilégios nas relações comerciais com o poder público para empresas privadas que aderissem as cotas para contratação de funcionários. Além disso, a nação brasileira passaria a "definir os direitos das pessoas com base na tonalidade da sua pele, pela 'raça'. A história já condenou dolorosamente estas tentativas" (Carta..., 2006). Continua argumentando que a adoção de identidades raciais não deve ser imposta e normatizada pelo Estado:

Políticas dirigidas a grupos "raciais" estanques em nome da justiça social não eliminam o racismo e podem até produzir o efeito contrário, dando respaldo legal ao conceito de raça, e possibilitando

24 Entre elas: André Campos - professor do departamento de História da UFF e da UERJ, Angela Porto - historiadora, pesquisadora do departamento de pesquisa da casa de Oswaldo Cruz/Fiocruz, Antonio Cícero - poeta e ensaísta, Bernardo Kocher - professor do departamento de História da UFF, Caetano Veloso, Gilberto Velho - professor titular e decano do departamento de Antropologia do Museu Nacional da Universidade Federal do Rio de Janeiro e membro da Academia Brasileira de Ciências, Lilia K. Moritz Schwarcz professora titular de antropologia da USP.

25 O representante do MNS, Carlos Miranda, afirmou que a maioria do Movimento Negro apoia as cotas, mas abandonou as lutas por uma sociedade mais justa e igualitária, e supõe que tal política aumentaria a situação de conflito e oposição entre brancos e negros (Moehlecke, 2002, p.211). 
o acirramento do conflito e da intolerância. A verdade amplamente reconhecida é que o principal caminho para o combate à exclusão social é a construção de serviços públicos universais de qualidade nos setores de educação, saúde e previdência, em especial a criação de empregos. Essas metas só poderão ser alcançadas pelo esforço comum de cidadãos de todos os tons de pele contra privilégios odiosos que limitam o alcance do princípio republicano da igualdade política e jurídica. (Carta..., 2006)

No livro Divisões perigosas: politicas raciais no Brasil contemporâneo, os autores consideram que as cotas representam uma ruptura de concepções profundamente calcadas no imaginário nacional, e veem isso como ameaça.

Os projetos [de cotas e do estatuto de igualdade] pretendem, em suma, transformar a nação brasileira em uma nação dividida em duas metades - uma feita de brancos e a outra, de negros. Trata-se de uma proposta de engenharia social que torna a racialização da sociedade legal e obrigatória. (Fry et al., 2007, p.14)

Para eles, a positividade do passado brasileiro advém do processo de mestiçagem, de hibridismo, responsável pelo processo pacífico de integração nacional (Fry et al., 2007).

De outro lado, houve um movimento determinado a apoiar as cotas universitárias e toda a política afirmativa racial. Os antropólogos José Jorge de Carvalho (UnB), Kabengele Munanga (USP) e José Carlos Gomes dos Anjos (UFGRS), as antropólogas Rita Segato (UnB) e Ilka Boaventura Leite (UFSC), o sociólogo Antônio Sérgio Alfredo Guimarães (USP), o economista Marcelo Paixão (UFRJ), a socióloga Ilse Scherer-Warren (UFSC), o físico Marcelo Tragtenberg (UFSC), a pedagoga Vânia Beatriz Monteiro da Silva (UFSC), a procuradora da Universidade Federal do Paraná (UFPR), Dora Lúcia Bertúlio, são alguns dos nomes que vieram a público defender as cotas raciais. 
Esses intelectuais mostram exemplos de experiências positivas em outros países; dados qualitativos e quantitativos levantados pelas pesquisas do IBGE e do Ipea comprovam a forte exclusão dos negros e mestiços na sociedade brasileira. Diante do quadro, a melhoria do ensino básico e secundário como uma solução para o problema da exclusão demandaria um tempo enorme; consideram que o preconceito racial existe e que, portanto, se o branco pobre sofre a discriminação uma vez, o negro sofre duas vezes, pela sua condição racial e pela socioeconômica; espera-se que o uso deste instrumento seja transitório, uma passagem para a construção da cidadania plena numa sociedade democrática. Enfim, se é verdade que o Brasil nunca legislou sobre o apartheid, "as teorias e as interpretações das relações raciais no Brasil sempre foram elas mesmas racializadas" (Carvalho, 2005, p.91). Kabengele Munanga, militante do Movimento Negro e professor aposentado de antropologia da USP, argumenta em favor das cotas como a única forma de aumentar o contingente negro no ensino universitário, "tirando-o da situação de $2 \%$ em que se encontra depois de 114 anos de abolição em relação ao contingente branco que sozinho representa $97 \%$ de brasileiros universitários" (Munanga, 2003).

Cinco dias após o manifesto contrário aos projetos das cotas raciais universitárias do Estatuto da Igualdade Racial, em 2006, entregue ao presidente do Senado Brasileiro, os apoiadores fizeram o mesmo movimento. Um manifesto favorável às cotas e ao Estatuto da Igualdade Racial foi redigido por Alexandre do Nascimento (membro da coordenação do movimento pré- vestibular para negros e carentes), por Frei David Raimundo dos Santos (diretor executivo da rede de pré-vestibulares comunitários: educação e cidadania de afrodescendentes e carentes), e por José Jorge de Carvalho (antropólogo da UnB e um dos responsáveis pelo projeto de ação afirmativa desta universidade). $\mathrm{O}$ manifesto recebeu 330 assinaturas e foi apoiado por mais de 60 
pesquisadores da área de Ciências Humanas e Sociais, entre eles, Selma Pantoja (UnB), Sidney Chalhoub (Unicamp), Robert Slenes (Unicamp), José Reginaldo Santos Gonçalves (UFRJ), Hebe Mattos e Daniel Aarão Reis (UFF) - e representantes de movimentos sociais de diversas regiões do país: Centro de Estudos e Defesa do Negro do Pará (Cedenpa), Coletivo Estadual de Estudantes Negros - RJ (Ceneg), Coletivo dos Estudantes Negros das Universidades da Bahia - BA (Cenunba).

$\mathrm{O}$ manifesto de apoio à política afirmativa refuta o argumento de que a inclusão de estudantes negros por intermédio de cotas provocará acirramento dos conflitos raciais nas universidades. $\mathrm{O}$ texto afirmou que este seria um panorama alarmista e que os casos de racismo surgidos com as cotas seriam resolvidos no interior das comunidades acadêmicas, com maior transparência e eficácia. E mais,

O manifesto que rejeita frontalmente as duas leis (Políticas Afirmativa e Estatuto da Igualdade Racial) em discussão não apresenta nenhuma proposta alternativa concreta de inclusão racial no Brasil, reiterando apenas que somos todos iguais perante a lei e que é preciso melhorar os serviços públicos até atenderem por igual a todos os segmentos da sociedade. ${ }^{26}$ (Confira..., 2006)

\section{Epílogo}

No dia 15 de junho de 2012, o auditório da Casa da Ciência, em Botafogo (RJ), recebeu o geneticista Sergio Danilo Pena (UFMG) e o historiador José Murilo de Carvalho (UFRJ) para

26 Confira a íntegra dos manifestos contra e a favor das cotas. Folha de S.Paulo, São Paulo, 4 jul. 2006. Disponível em: <http://www1.folha.uol.com.br/ folha/educacao/ult305u18773.shtml>. Acesso em: ago. 2013. 
um debate sobre a evolução recente da genética e da história, com foco na individualidade. $\mathrm{O}$ geneticista refutou o conceito errôneo de raça para classificar o brasileiro, e o historiador, o conceito determinista da história (Garcia, 2012). À guisa de epílogo, comentaremos somente o trabalho do geneticista, já que não é o momento de adentrarmos as questões metodológicas da história, tratada por José Murilo de Carvalho.

Sergio Danilo Pena, o geneticista, fundamentou-se em resultados de pesquisas que vinha efetuando desde 1995 sobre as características genéticas do povo brasileiro. $\mathrm{O}$ método consiste na verificação do cromossomo $Y$, traço passado de pai para filhos homens, e do DNA mitocondrial, passado da mãe para todos os filhos, "como uma espécie de máquina do tempo capaz de identificar a contribuição de brancos, negros e índios para a configuração genética da população”. Em 2000, Pena publicou o artigo "Retrato molecular do Brasil" mostrando o resultado das análises feitas numa amostragem de 147 indivíduos brancos. ${ }^{27}$ O resultado revelou a presença surpreendente de 60\% de matrilinhagens ameríndias e africanas em brasileiros brancos (Pena, 2000, p.20).

Em 2004, sai um novo artigo de Pena, desta vez em coautoria com Maria Cátira Bortolini, no contexto do debate sobre cotas raciais no Brasil (Pena; Bortolini, 2004). A conclusão geral do estudo foi a de que há enorme contribuição do negro para a formação da população brasileira, de modo que $87 \%$ dos brasileiros, em 2000, na amostragem, apresentaram pelo menos $10 \%$ de ancestralidade africana. Por outro lado, em Queixadinha, no Vale do Jequitinhonha, região nordeste de Minas Gerais, apenas $73 \%$ dos classificados como pretos apresentaram proporção

$27 \mathrm{O}$ autor informa que utilizou apenas indivíduos que se declaram brancos porque a população negra já havia sido objeto de estudo, na década de 1970, para aferição da proporção de genes europeus em negros brasileiros. 
superior a 50\% de ancestralidade africana (Pena; Bortolini, 2004, p.43). Os dados mostram também que $48 \%$ dos afrodescendentes brasileiros, ou seja, dos que têm ascendência genética africana, se autoclassificam como brancos. Na região Sul, mais de dois terços (72\%) dos afrodescendentes consideram-se brancos. "A conclusão impressionante é que em nosso país, mais de $90 \%$ apresenta pelo menos 10\% de ancestralidade africana!” (Pena; Bortolini, 2004, p.43).

Os autores concluem que os resultados da pesquisa mostram que os afrodescendentes são em número bem maior do que aqueles que aparentam ser por suas características físicas, chegando ao número impressionante de 146 milhões de pessoas e, por outro lado, muitos dos que se identificam como negros apresentam uma proporção significativa de ancestralidade europeia pela carga genética que receberam dos pais, e muitos dos que se identificam como brancos apresentam ancestralidade negra pela carga genética que receberam das mães. "Dessa maneira, não é nada surpreendente que existam confusões e problemas relacionados aos critérios adotados para definir quem deve ser beneficiado pelas políticas de ação afirmativa no Brasil" (Pena; Bortolini, 2004, p.45).

Ora, o resultado da pesquisa de Sergio Pena e Maria Cátira Bortolini; além de corroborar com a tese de que as doutrinas raciais científicas sempre estiveram equivocadas, ainda demonstra que o preconceito racial no Brasil, tal como vimos ao longo deste capítulo, não advém da ancestralidade genética.

Nossa distinção racial não se coloca no plano do genótipo, mas no fenótipo. Talvez, por isso, o movimento negro, cada vez menos, tem usado o termo afrodescendente para designar o negro brasileiro. Afrodescendente, se levarmos em conta a pesquisa do geneticista citado, somos quase todos e todas. Mas se somos "iguais" na origem genética, apresentamo-nos de forma muito desiguais nos espaços sociais, políticos, econômicos e culturais. 
Nessa seara, é preciso inverter a ordem das coisas. Se o liberalismo nos acostumou a tratar igualmente os desiguais, "as políticas afirmativas" aplicam modos desiguais de tratar aqueles que sentem na "pele" o preconceito da raça, como forma de reparação histórica. As políticas afirmativas proporcionam a inserção de contingentes negros no campo das possibilidades sociais, culturais e econômicas, e as cotas universitárias favorecem a entrada deles na universidade. Em 2002, no início do debate, Kabengele Munanga (2003), como vimos anteriormente, apresentou as seguintes cifras para fundamentar a defesa das cotas universitárias: 97\% dos universitários são brancos, 2\%, negros e 1\%, outros. De lá para cá, os números já se modificaram: universitários brancos (31,1\%), pardos e pretos $(13,4 \%$ e 12,8\%, respectivamente), de acordo com Censo 2010 do Ministério da Educação. ${ }^{28}$ É ainda desproporcional, se considerarmos que a população branca perfaz $47,7 \%$ e a negra, somando pardos e pretos, é de 50,1\%, mas a desproporção já é menor que aquela vista em 2002. Dizer que as políticas afirmativas racializam o Brasil é uma meia verdade. As políticas afirmativas raciais ou a "discriminação positiva" lidam com um país que foi racializado desde que se começou a falar em nação brasileira, em meados do século XIX.

28 Cf. <http://www.brasil.gov.br/noticias/arquivos/2013/05/10>. Acesso em: ago. 2013. 


\title{
Das relações com o corpo no Brasil
}

\author{
Jean Marcel Carvalho França ${ }^{1}$ \\ Ana Carolina de Carvalho Viotti ${ }^{2}$
}

O sociólogo e antropólogo Marcel Mauss (1872-1950), sobrinho do renomado Émile Durkheim - sob quem exerceu grande influência -, escreveu em um ensaio de $1935^{3}$ que, no tocante às atitudes do corpo, "cada sociedade tem seus hábitos próprios" (Mauss, 1974, p.403). Tais hábitos, como esclarece, não variam "simplesmente com os indivíduos e suas imitações, variam sobretudo com as sociedades, as educações, as conveniências e as modas, os prestígios" (Mauss, 1974, p.404).

Em terras que gradativamente se consolidaram como Brasil, as considerações do antropólogo Mauss são especialmente instigantes, afinal, poucas são as culturas em que o corpo, sua exibição, sua manutenção e o uso dos prazeres que proporciona

1 Professor livre-docente de História do Brasil do Departamento de História da Unesp e autor, entre outros livros, de A construção do Brasil na literatura de viagem dos séculos XVI, XVII e XVIII.E-mail: jsfranca@uol.com.br.

2 Doutoranda em História no Programa de Pós-Graduação em História da Universidade Estadual Paulista "Júlio de Mesquita Filho" (Unesp), câmpus de Franca (SP), e historiógrafa do Centro de Documentação e Apoio à Pesquisa Histórica (CEDAPH) da mesma universidade.

3 Publicado originalmente no Journal de Psychologie, v.32, n.3-4, 1935. Comunicação apresentada à Sociedade de Psicologia em 17 de maio de 1934. 
ocuparam, e ocupam, um papel tão central; ao menos é o que contam os relatos de viagem e os sermões coloniais, as teses médicas e os romances do Oitocentos, ou as mídias eletrônicas da segunda metade do século XX e início do XXI, para ficarmos nuns poucos exemplos.

Há, pois, é lógico supor, um verdadeiro continente de relações que historicamente os brasileiros mantiveram com o seu corpo. De tão amplo território queremos aqui mapear somente um pequeno feudo: aquele referente às atitudes relacionadas à saúde e à doença dos corpos. Grosso modo, não seria equivocado dizer que - tomemos a partilha como uma hipótese inicial -, quando o que está em causa é a manutenção dos corpos e a cura de seus males, criamos no Brasil, em cinco séculos, ao menos três grandes modos de entendimento, um deles ainda em vias de consolidação. É a história desses três modos que buscaremos, em linhas muito gerais, aqui descrever.

\section{O corpo místico}

Em 1740, João Pedro Xavier do Monte, médico português natural de Santarém, deu à prensa uma obra intitulada $O$ homem médico de si mesmo, na qual, entre outras coisas, afirmava: "são as doenças e os enfermos mais frequentes no mundo do que os médicos, e o seu insulto mais pronto que a medicina, e o padecer essas doenças mais certo e fácil do que remediá-las; em todo o mundo há doenças e enfermos, e em poucas partes dele se acham médicos" (Monte, 1760, p.26). A constatação de Xavier do Monte, em plena metade do século das luzes, indica a diminuta presença entre os portugueses, até aquela data, de doutores formados. E isso na metrópole. Atravessando o Atlântico, na denominada por vezes América Portuguesa, a ausência dos doutos é ainda mais notável; aqui, ele é praticamente um desco- 
nhecido (Santos Filho, 1966, 1991, 1947, 1960). Malgrado tamanha ausência, os naturais da terra, os colonos e seus escravos adoeciam, preocupavam-se com seus corpos e procuravam com afinco meios de amenizar as suas dores e prolongar as suas vidas. Mas se era difícil, quase impossível, e mesmo pouco desejável, contar com os médicos, onde buscar ajuda e que medidas tomar diante de um achaque qualquer?

Entre o Seiscentos e o Setecentos, é sobretudo aos religiosos, notadamente aos jesuítas, que a população recorria quando seu corpo era acometido por algum mal. Embora sua ação nos trópicos estivesse a princípio endereçada ao tratamento das almas, as circunstâncias de então os levaram a tratar, também, dos achaques dos corpos. Até mesmo a sangria, que, a priori, seria vedada aos religiosos praticar, passa a ser permitida através de legislação canônica especial (Algunas..., p.45), dada a necessidade de atender aos doentes e cumprir o Compromisso da Ordem, datado de 1516. Das instruções com o cuidado corporal presentes nos Compromissos, destacam-se: "resgatar os cativos e visitar os prisioneiros, tratar dos doentes, vestir os nus, alimentar os famintos, dar de beber aos sedentos, abrigar os viajantes e os pobres, sepultar os mortos" (apud Russel-Wood, 1981, p.90).

Para os religiosos, no entanto, curar os doentes não era somente tratar dos corpos enfermos, era necessário ir além e cuidar também da parte realmente nodal do ser humano, a alma; como bem explica o arcebispo da Bahia, Sebastião Monteiro da Vide (1642-1722): "como muitas vezes a enfermidade do corpo procede de estar a alma enferma com o pecado [...] que indo visitar algum enfermo, antes que lhe apliquem medicinas para o corpo, tratem primeiro da medicina da alma" (Vide, s.d., p.74). Aplicar primeiro a medicina da alma, explica o próprio Vide, implicava, de imediato, em orar para que o doente se livrasse de seus pecados e zelar para que não adquirisse outros: 
E outrossim mandamos aos ditos médicos e cirurgiões, sob pena de excomunhão maior e de dez cruzados aplicados na forma sobredita, que não aconselhem ao enfermo por respeito da saúde do corpo coisa que seja perigosa para a alma. E exortamos a todos os familiares e parentes do enfermo, que tanto que adoecer deem logo recado ao pároco, e persuadam ao doente a que, com efeito, faça confissão de seus pecados. (Vide, s.d., p.74)

Em verdade, tal medicina se caracterizava como um conjunto de práticas que deveria ser adotada permanentemente durante toda a vida. E, admitamos, cuidar do espírito do nascimento até a morte, adotando uma conduta reta do ponto de vista cristão, para que inclusive o corpo não adoecesse, não era tarefa fácil.

De saída, era preciso receber o sacramento do batismo, preferencialmente na mais tenra idade. Para garantir um lugar junto a Deus, como nos conta José de Anchieta (1534-1597) e tantos outros conhecidos irmãos, receber o primeiro dos sacramentos era imprescindível, dado que, além de iniciar o pecador no caminho da salvação, "apagava a malignidade das doenças" (Anchieta, 1933, p.180). Os religiosos empenhavam-se, assim, "na intenção de preparar o recebimento do batismo [...], desejando assistir mesmo as parturientes a fim de batizar mãe e filho; assim acontece atender-se a salvação do corpo e da alma" (Breve..., s.d., p.147). Aos olhos desses homens de Deus, autointitulados médicos espirituais e corporais, mesmo as enfermidades consideradas incuráveis aos doutos seriam extirpadas com a unção pela água, indicando a estreita relação entre a conversão à doutrina cristã e a cura dos corpos.

Há inúmeras passagens nas missivas dos religiosos sobre a aplicação do sacramento da imersão, passagens que contam os sucessos alcançados pelos convertidos; é o caso, por exemplo, de um homem gravemente ferido que, após ser submetido ao batismo e tratado pelos religiosos, não teve curados somente seus 
machucados purulentos, mas, especialmente, as chagas da sua alma (Carta...). Daí, os padres da Companhia não cansarem de registrar: é "maravilhoso ver como sanam todos que se batizam" (Documentos para la historia argentina, 1927, p.89). Mesmo diante de uma vitória da morte, um aparente fracasso do processo de cura, os jesuítas extraíam lições positivas. A respeito de um infante enfermo da vila de São Vicente, em 1560, o citado Anchieta relata: "foi-nos apresentada uma criancinha quase prestes a expirar e falando nós a seus pais para batizá-la, eles anuíram de boa mente a isso; batizamo-la, e algumas horas depois foi levada para o céu" (Anchieta, 1933, p.110). Ora, nesse caso, o pequeno gentil não fora malogrado pela morte, ao contrário, segundo o irmão, recebera, ao abandonar cedo um corpo sujeito a toda a sorte de pecados, o prêmio da vida eterna pela intervenção do batismo.

Os autóctones, a propósito, dotados, segundo o Padre Jerônimo Rodrigues, de uma "espontaneidade animalesca", não possuíam nenhuma habilidade em portarem-se socialmente, pois “ [...] aonde à vontade de urinar os toma, aí o fazem, na rede, onde estão comendo, na porta [...] falando com homem e muitas vezes nos nossos pés com mãos e braços entrecruzados sem atentarem o que fazem nem se darem por achados de tal sujidade" (Leite, 1940, p.238). Tomados, porém, como almas que deveriam ser salvas para Deus, os naturais da terra receberam, até meados do século XVII, especial atenção dos religiosos, que lhes ofereciam "socorro espiritual, confessando-os e batizando-os, e corporal, sangrando-os e curando-os, segundo a necessidade de cada um" (Anchieta, 1933, p.248).

Ainda no século XVII, a partir do aumento da presença de negros de Guiné - uma designação corrente para os escravos vindos da África -, o olhar e as prescrições dos padres passam a ser também a eles direcionados. As recomendações do conhecido jesuíta André João Antonil indicam a crescente preocupação com a regulação das tarefas e do trato desses escravos, recomen- 
dações que iam desde o abrandamento do trabalho quando do acometimento de alguma doença, até a atenção aos sacramentos na hora da morte:

Adoecendo qualquer escravo, deve livrá-lo do trabalho e pôr outro em seu lugar e dar parte ao senhor para que trate de o mandar curar, e ao capelão para que o ouça de confissão, e o disponha, crescendo a doença, com os mais sacramentos para morrer. Advirta que se não metam no carro os bois que trabalharam muito nos dias antecedentes, e que em todo o serviço assim como se dá algum descanso aos bois e aos cavalos, assim se dê, e com maior razão, por suas esquipações aos escravos. (Antonil, 1982, p.84)

Para Antonil, aos senhores não convinha que seus escravos fossem "só reconhecidos na repartição do trabalho e esquecidos na doença e na farda" (Antonil, 1982, p.91). O religioso italiano argumenta que

[...] deve o senhor de justiça dar suficiente alimento, mezinhas na doença e modo com que decentemente se cubra e vista, como pede o estado de servo, e não aparecendo quase nu pelas ruas; e deve também moderar o serviço de sorte que não seja superior às forças dos que trabalham, se quer que possam aturar. (Antonil, 1982, p.90-91)

Outro padre, o lisbonense radicado na Bahia Manoel Ribeiro Rocha, procurou frisar em muitos momentos do seu Etíope resgatado... (1758) que o cuidado com o cativo não deveria faltar quando estivesse inútil para o trabalho, achando-se ele

enfermo ou estiver já velho, que tudo vale o mesmo, com muito maior razão o devemos conservar, porque então a sua maior necessidade puxa pelo nosso maior agradecimento e obrigação, de sorte 
que obrando o contrário, podemos justamente temer e recear o castigo. (Rocha, 1758, p.315)

Rocha assevera, além disso, que não era aconselhável irromper golpes na face dos escravos durante a aplicação de algum castigo, porque os

[...] expõem ao perigo de lhes causar alguma deformidade perpétua no rosto, e de lhes prejudicar à saúde, e talvez à vida; e isto será obrarem mais como seus verdugos do que como seus senhores; e será mais usar do poder domínico, para os destruir, do que de castigo econômico, para os emendar; e será fazer injúria aos escravos, e tratá-los com aspereza e duramente. (Rocha, 1758, p.208)

As indicações desses religiosos no que concerne ao cuidado com o escravo são múltiplas: o senhor deveria assistir sua propriedade na doença, no sustento alimentar e ter parcimônia na aplicação das correções físicas, tanto para a conservação de seu escravo, quanto para o livramento de sua culpa perante Deus e também perante os homens. ${ }^{4} \mathrm{Um}$ decênio antes da publicação de Cultura e opulência do Brasil por suas drogas e minas (1711) e mais de meio século antes da publicação de $O$ Etíope resgatado, empenhado, sustentado, corrigido, instruído e libertado (1758), Jorge Benci já afirmava que "de todos os bens naturais o único, de que goza o escravo é a saúde", razão pela qual, quando adoeciam, mereciam "mais compaixão, sendo o estado dos servos enfermos mais miserável que o de todos os outros enfermos" (Benci, s.d., p.74).

4 "O Direito Civil impõe graves e condignas penas aos possuidores de escravos, que faltarem e se descuidarem destas suas obrigações; pois aos que lhe não acudirem com alimentos e medicamentos necessários na enfermidade, e nela os desampararem, lhes tira totalmente o domínio" (Rocha, 1758, p.152-153). 
Precedendo em pouco mais de meio século a Economia cristã dos senhores no governo de escravos (1705), um dos maiores pregadores em língua portuguesa daqueles tempos, o Padre Antônio Vieira, valeu-se do escravo como protagonista, ou melhor, como uma das tópicas centrais de seus escritos. Nas obras anteriores ao seu Sermão XIV, de 1633, os sujeitados aos senhores ainda apareciam de modo marginal nas descrições do novo mundo, perdendo espaço para as então conhecidas "grandezas do Brasil”, como nomeou Ambrósio Fernandes Brandão (1618): a terra e o gentio. A partir dessa pregação de 1633, na Irmandade dos Pretos na Bahia, a urgência e obrigatoriedade do senhor em tratar do corpo - nas dimensões física e espiritual - dos escravos ${ }^{5}$ ganham realce. Considerando que "não há trabalho nem gênero de vida no mundo mais parecido à Cruz e Paixão de Cristo que o vosso [do escravo] em um destes engenhos" (Vieira, 1998), Vieira aconselha que os cativos, como os gentios e os demais colonos, fossem incorporados "em Cristo pela fé e o batismo", como sinal de arrependimento de seus pecados e purificação de seu corpo e espírito.

Branco ou negro, escravo ou livre, nota-se que toda a atenção com o corpo - gestos, atos, saúde ou doença - passava, pois, incontornavelmente, pelo crivo da relação com o espírito. $\mathrm{O}$ doutor Francisco de Melo Franco, já em finais do século XVIII, sintetiza essa relação. Em suas palavras, os confessores

sabem também como a alma obra no corpo, e o corpo na alma, sabem como ambos se comunicam, e se firmam em suas paixões e adquirem suas virtudes; e depois de conhecido o jogo deste meca-

5 “E que confusão, pelo contrário, será para os que se chamam senhores de engenho, se atentos somente aos interesses temporais, que se adquirem com este desumano trabalho, dos trabalhadores seus escravos, e das almas daqueles miseráveis corpos, tiverem tão pouco cuidado, que não tratem de que louvem e sirvam a Deus, mas nem ainda de que o conheçam?" (Vieira, 1998). 
nismo oculto, desta simpatia admirável, tiram indicações seguras, formam juízos certos e aplicam remédios não só morais, mas também físicos, ou proporcionam ambos de modo que facilmente curem os pecadores de suas enfermidades espirituais e corporais, $e$ os dirigem em fim nos caminhos da saúde do corpo e da salvação da alma. (Franco, 1794, p.15-16)

Todavia, uma vez aplicados os remédios morais, era preciso passar aos físicos. Nesta matéria, religiosos e diplomados dispunham de um arsenal de ferramentas e fórmulas limitadas e comuns: ao lado das citadas sangrias, eram as purgas os tratamentos mais comuns; usava-se, ainda, emplastros, pomadas, xaropes, pós, supositórios, lambedores, pílulas, colírios, clisteres, vomitórios, remédios líquidos, pastosos e licorosos. ${ }^{6}$ Os jesuítas, inclusive, eram reconhecidos pela maestria na manipulação de fármacos; não por acaso, em 1703, um traficante de escravos francês, de passagem pelo Rio de Janeiro, destacou: "a botica mantida por essa casa é excelente: bem decorada, asseada e provida de todos os tipos de drogas. Julgo não possuirmos, em França, nenhuma que se lhe compare. Essa botica dos padres abastece todas as outras da cidade" (Journal d'un Voyage, 2008, p.80-81).

Mesmo que munidos de muitos remédios para o corpo, a percepção dos religiosos sobre os doentes sustentou-se, durante todo o período colonial, na ideia de que o manifesto no exterior é, na verdade, um espelho das chagas da alma. Dito de outro modo, de nada adiantaria cuidar dos males do corpo se a alma ainda padecesse, especialmente em razão de vícios morais ou da falta de assiduidade no exercício do catolicismo. Ainda que a pena de muitos padres tenha sido empunhada para tratar da

6 Cf., entre outros: Cunha, 2004; Leite, 1936; Gomes, 1974; Marques, 1999; Nava, 2003; Ribeiro, 1971; Ribeiro, 1997; Studart, 1997. 
matéria médica e de toda uma farmacopeia passível de ser empregada no combate às doenças, é a produção de uma espécie de "medicina teológica" o seu maior legado. Obras como a de Ângelo de Sequeira, que defendiam que "é Maria Santíssima a verdadeira botica preciosa" (Sequeira, 1754, p.5) e que seus feitos "deixam a perder de vista a todas as ciências, e prodígios da natureza" (Sequeira, 1754, p.3), obtiveram prestígio e notoriedade. É, pois, compreensível que, em 1749, nas Minas do Sabará, se acreditasse piamente que as águas de uma lagoa santa fosse o mais frutuoso remédio contra toda sorte de achaques.

O que se nota, em suma, é que, para os homens da colônia, a percepção do próprio corpo, saudável ou enfermo, sustentava-se numa relação com o sagrado, ou melhor, com o místico. Mesmo cirurgiões diplomados, como José Antônio Mendes, aconselhavam que o tratamento, para ter sucesso, deveria "logo mandar confessar e sacramentar o enfermo, [...] comungar, buscando a Deus como Pai e Mestre de todo o criado, que este mesmo há de vencer melhor a tal queixa" (Mendes, 1770); enfim, não seria errado concluir que, para os homens de então, religiosos e leigos, diplomados ou não, cuidar dos corpos era, antes de tudo, lançar mão de remédios morais e cuidar das almas.

\section{O corpo medicalizado}

O século XIX, logo na sua década inicial, viu nascer no Brasil uma relação nova com o corpo, relativamente distante daquela que vigorara nos séculos iniciais da colônia: o corpo medicali$z a d o$, o corpo que gradativamente se submete a uma nova maneira de encarar a saúde e a doença - o normal e o patológico, como então se dizia -, a maneira médica (Santos Filho, 1960). A medicina, até 1808, quando D. João VI transferiu a sua corte para o Rio de Janeiro, não tinha, como pudemos acompanhar, grande presença ou prestígio nem aqui nem no reino. Em 1789, 
segundo o vice-rei Luís de Vasconcelos e Sousa (1778-1790), havia somente quatro médicos no Brasil e os cirurgiões eram tão poucos que um mesmo profissional, geralmente um empírico com pouca ou nenhuma formação, era obrigado a estender os seus domínios clínicos por um raio de mais de 300 léguas. Toda a regulamentação da atividade estava a cargo do Físico e do Cirurgião-mor do Reino (Canguilhem, 2000) que, sediados em Lisboa, daí, supostamente, fiscalizavam o exercício da profissão e lavravam as licenças e os autos de habilitação para o seu exercício. Na prática, tal regulamentação inexistia em solo brasileiro. A atividade aqui era exercida, quase sem concorrência, por religiosos, sangradores, boticários e curandeiros. Os médicos diplomados eram uma categoria praticamente desconhecida dos brasileiros.

Quando D. João VI desembarca no Rio de Janeiro em 1808, essa situação começa a se alterar. Em abril do mesmo ano, o monarca preocupado com a saúde de seus súditos - sobretudo com a de seus cortesãos, que não paravam de adoecer nos trópicos ${ }^{7}-$ nomeou o cirurgião da armada, Antônio Joaquim da Rocha $\mathrm{Na}$ zarém, como lente de anatomia do Hospital Militar, a fim de que ele aí ministrasse um curso de ligaduras, partos e operações de cirurgia. Em 1809, o mesmo cirurgião foi nomeado professor de medicina operatória e arte obstetrícia. Criava-se, assim, a Escola Cirúrgica e Médica do Rio de Janeiro. Em dezembro do ano seguinte, uma ordem régia determinou o envio de três alunos da escola do Rio de Janeiro para estudarem em Edimburgo por conta do Real Tesouro, esperava-se com tal medida obter melhores professores para compor o deficitário quadro docente da escola recém-criada.

7 Acerca da saúde precária dos cortesãos instalados no Rio de Janeiro, ver: "Cartas de Luiz Joaquim dos Santos Marrocos, escritas à sua família em Lisboa, de 1811 a 1821”. In: Anais da Biblioteca Nacional do Rio de Janeiro, v.LVI,1934. 
Em 1812, executando um plano do doutor Manuel Luís Álvares de Carvalho (Diretor dos Estudos Médicos e Cirúrgicos da Corte do Brasil), fundou-se no Rio de Janeiro a Escola Médico-cirúrgica. O curso ministrado por essa instituição durava cinco anos, e em seu currículo constavam as seguintes matérias: Anatomia Geral, Química Farmacêutica, Fisiologia, Higiene, Etiologia, Patologia, Terapêutica, Instruções Cirúrgicas e Operatórias, Arte Obstetrícia e Medicina. A Escola concedia o título de cirurgião aprovado a quem seguisse o curso regular e o título de cirurgião formado ao aluno que repetisse, num sexto ano, as matérias lecionadas no quinto ano. Finalmente, em 1832, coroando essa série de esforços, a Escola Médico-cirúrgica foi transformada em Faculdade de Medicina do Rio de Janeiro. Reorganizou-se o currículo e instituiu-se três cursos: o de Farmácia, o de Medicina e o de Partos.

Constou o ensino médico de quatorze disciplinas, distribuídas do primeiro ao sexto ano: Física Médica, Botânica Médica e Zoologia, Química Médica e Mineralogia, Anatomia Geral e Descritiva, Fisiologia, Patologia Externa, Patologia Interna e Farmácia com terapêutica e arte de formular, Anatomia topográfica com medicina operatória e aparelhos, Partos com moléstias de mulheres pejadas e paridas e moléstias de meninos recém-nascidos, Higiene e História da Medicina, Medicina Legal, Clínica Externa e Anatomia Patológica respectiva, e, finalmente, Clínica Interna e Anatomia Patológica respectiva. (Holanda, 1967, v.3, p.468)

Para ingressar na faculdade, exigia-se do candidato o conhecimento de filosofia, aritmética, geometria e de uma língua estrangeira, que poderia ser ou o latim, ou o inglês, ou o francês, sendo essa última a preferida. O título de doutor em Medicina era conferido ao sextanista que defendesse em público uma tese escrita em vernáculo ou em latim. A faculdade contou, nas suas 
duas décadas iniciais de atividade, com uma grande procura e concedeu o seu prestigiado diploma a quase uma centena de profissionais.

Ao lado da Escola Médico-cirúrgica e, posteriormente, da Faculdade de Medicina atuou, desde 1829, a Sociedade de Medicina e Cirurgia do Rio de Janeiro. A instituição, fundada em junho do ano supracitado e instalada em abril de 1830, foi extremamente importante para a consolidação do saber médico em solo brasileiro. A sociedade, transformada em academia no ano de 1834, atuou em três fronts principais: lutou pela regulamentação da profissão e pela punição dos charlatões; requereu junto às instâncias públicas uma maior participação da corporação médica na elaboração de políticas sanitárias; e agilizou a publicação de revistas, livros, tratados, traduções e tudo o mais que pudesse servir para divulgar o saber médico e melhor formar os profissionais do setor. ${ }^{8} \mathrm{O}$ doutor Alfredo do Nascimento, nas comemorações do centenário da Academia, em tom panegírico, assim sintetiza a ação desse órgão nas primeiras décadas do Oitocentos:

A Academia, instituída no período inicial da organização da nossa Pátria, foi contemporânea de toda esta fase transformadora das Ciências Médicas. Naqueles tempos, todos os problemas da higiene pública, o estudo das epidemias reinantes, a indicação dos meios de prevenir e curar, o registro demográfico sanitário, os assuntos de interesse profissional e pedagógicos, as discussões médico-legais, os debates sobre os casos clínicos, os pronuncia-

8 O primeiro periódico médico lançado no Brasil intitula-se O Propagador das ciências médicas ou Anais de medicina, cirurgia e farmácia, editado no Rio de Janeiro em 1827 pelo Dr. Francisco Xavier Sigaud. Depois d'O Propagador (1821-1828), foram editados o Semanário de saúde pública (1831-1833), a Revista médica fluminense, a Revista médica brasileira (1841-1843), os Anais de medicina brasiliense (1845-1848) e, finalmente, os Anais brasilienses de medicina (1849-1884), todos através da Sociedade de Medicina. 
mentos sobre questões de exercício da profissão, os problemas de ontologia e ética médica, tudo isso era de lá que saía. (Nascimento, 1929, p.222-223)

Esse trabalho de institucionalização e consolidação do saber médico em solo brasileiro, trabalho desenvolvido, sobretudo, pela Academia de Medicina a partir do Rio de Janeiro, deu-se paralelamente à elaboração da imagem pública do profissional de saúde. Recordemos que nessa época, de implantação e expansão do saber médico no país, ao menos nas suas cidades mais populosas do litoral, o médico gozava de um prestígio social muito reduzido e era pouco ouvido no tocante às relações que o indivíduo mantinha com o seu corpo. A população, que durante muito tempo prescindira dos serviços de profissionais habilitados, estava longe de encará-los como os únicos capazes de zelar pela sua saúde e conservação dos seus corpos. Os mencionados religiosos, boticários, sangradores, parteiras e curandeiros eram muito mais requisitados e concorriam em pé de igualdade, ou mesmo em vantagem, com os pouco e mal formados doutores saídos dos bancos das faculdades, sobretudo da portuguesa Coimbra.

Atenta a tal situação, a classe médica tratou de construir junto aos habitantes da corte e do país uma imagem capaz de lhe garantir a legitimidade necessária para requisitar o monopólio da cura e o controle dos corpos. O primeiro ponto que mereceu a atenção da categoria foi aquele referente à formação de seus quadros; afinal, um profissional bem formado não somente melhor cumpriria as suas delicadas funções, como ainda despertaria nos pacientes uma salutar confiança.

Mas, aos olhos da corporação, em que consistia uma boa formação? Em linhas gerais, ela deveria atender a pelo menos duas exigências básicas. Primeiramente, dotar o profissional de um arcabouço teórico e conceitual que lhe permitisse um conhe- 
cimento detalhado e sólido de seus pacientes, conhecimento tanto dos problemas orgânicos quanto daqueles de natureza espiritual. Como recomendava o doutor Manoel de Castro Santos, em 1846, no seu trabalho A inteligência do homem explicada pelo sistema frenológico:

[...] a função da medicina é restabelecer ao estado normal uma função fisiológica qualquer, [...] mas [para tal] é preciso conhecer o paciente $[\ldots]$, as leis que o governam, as partes constituintes do seu corpo, a influência do físico sobre o moral e a relação da matéria com o espírito. (Santos, 1846, p.10)

A boa formação, porém, não deveria munir o profissional somente de um saber restrito à sua área de atuação; quando eficaz, ela deveria dotá-lo também de uma ampla cultura geral e de uma boa capacidade de expressão, itens fundamentais para que o seu discurso se tornasse mais persuasivo, consistente e, consequentemente, portador de maior autoridade. Acerca de tema tão sensível assim se manifestava, em 1846, o doutor Antônio Teixeira da Rocha:

E não me venham dizer que o médico não carece de eloquência para ser perfeito em sua arte, o talento de falar e escrever bem entra por muito na persuasão das verdades, e as verdades médicas são de suma importância. O estilo concorre poderosamente para facilitar o ensino, e ajudar a inteligência. $\mathrm{O}$ orador ou escritor médico deve ter eloquência para persuadir e estilo para facilitar. A arte de bem falar é necessária por mais não fosse, para levar a convicção a muitos doentes, que pusilânimes [...] não querem se sujeitar aos meios terapêuticos. (Rocha, 1846, p.15-16)

Todavia, a consolidação da imagem do profissional de saúde habilitado não dependia somente da boa formação. Era preciso, 
em paralelo, realizar uma espécie de trabalho negativo, trabalho de combate ao charlatanismo. Antes do desembarque, os agentes responsáveis pela fiscalização da arte de curar faziam vista grossa aos inúmeros práticos que atuavam na colônia. Mais que isso, a Fisicatura, cônscia da enorme carência de médicos formados (no período colonial eles nunca ultrapassam o número de dez), concedia muitas permissões a cirurgiões práticos. O inglês John Luccock, em 1808, poucos meses após a chegada de D. João VI, tece um comentário bastante ilustrativo da situação:

$[\ldots]$ creio $[\ldots]$ que anteriormente à vinda da Corte não existia um único médico que tivesse sido regularmente educado nas escolas de medicina de Portugal. Tampouco existiam cirurgiões, constituindo um ramo distinto da profissão; as operações menores eram praticadas por barbeiros, enquanto que as mais importantes por homens completamente ignorantes da anatomia. A habilidade dos boticários em diagnosticar e curar doenças era pouquíssimo superior ao conhecimento que detinham do corpo humano. O detalhe dos seus processos absurdos de tratamento provocaria incredulidade, tanto quanto maravilha pelo fato de os pacientes escaparem vivos e inteiros. (Luccock, 1975, p.70-71)

A partir da chegada do monarca português, a carência de médicos diplomados, bem como dos meios para diplomá-los devidamente, vai sendo superada. Cresce o número de médicos habilitados e instaura-se entre eles o firme propósito de combater os antigos e variados praticantes da arte de curar. Nesse sentido, muitas são as medidas tomadas: cobra-se um maior desvelo das autoridades no tocante à fiscalização do exercício da profissão; desqualifica-se sistematicamente a atividade dos práticos, associando-a a condutas bárbaras e, ao mesmo tempo, contrastando-a com os procedimentos racionais, científicos e civilizados dos profissionais formados; e, sobretudo, opõe-se 
a atividade especulativa e interesseira do charlatão àquela $f i$ lantrópica e desinteressada do médico. Um curioso e contundente exemplo dessa última estratégia pode ser encontrado no romance $O s$ dois amores, do médico e literato Joaquim Manuel de Macedo, no qual em tom apaixonado o narrador compara os procedimentos do charlatão e do médico:

$[\ldots]$ aquele que $[\ldots]$ anda por aí curando, se pode, os seus doentes, tendo em mira somente o pobre interesse; que só presta o seu conselho a troco de ouro; [...] esse... é apenas um mercador de receitas. Mas aquele que [...] não faz distinção entre rico e pobre, e só vê indivíduos que de seus cuidados carecem; aquele que combate as enfermidades, disputando contra a morte dia por dia, hora por hora, instante por instante, o campo da vida; que invade corajoso a atmosfera da peste; que se expõe com marcial bravura ao contágio mortífero, respirando aqui ar miasmático e envenenado, banhando-se ali em suor fétido e peçonhento, para caridoso levar socorros a infelizes, de quem sabe não receberá um ceitil; aquele que nem mesmo desanima, nesse viver trabalhoso, ante o monstro que tantas mil vezes fere o coração do médico - a ingratidão; - que paciente se amolda à impertinência da infância, ao capricho da velhice e ao pudor da virgindade; que não conhece no homem só os padecimentos da matéria; que entende e fala também o idioma da sensibilidade, o eloquente dizer da alma; aquele que tem [... nos lábios consolações salutíferas para com elas abrandar os tormentos do infeliz; e no coração uma sepultura para eternamente encerrar os segredos das famílias; esse sim... esse é médico. (Macedo, 1964, p.8-9)

O combate ao charlatão, como se vê, não visava somente desacreditar esse nocivo e perigoso usurpador de direitos, visava também exaltar os dotes dos profissionais formados. Opondo-se ao religioso desconhecedor da ciência, ao curandeiro mercenário, ao bárbaro pajé, à desqualificada parteira, ao rude boticário, 
ao ignorante sangrador, pôde o médico, de um só lance, eliminar a concorrência e, ao mesmo tempo, salientar o seu sólido conhecimento científico, seu senso humanitário, sua devoção à causa da vida e sua preocupação com a saúde e bem-estar dos corpos que habitavam as cidades. Daí o caráter decisivo desse combate para a elaboração da imagem pública do profissional de saúde, o quão decisivo ela foi para a definitiva afirmação do médico como o único capaz de promover a cura e preservar os corpos.

Esboça-se, ao término desse rápido percurso, a imagem do médico ideal, construída ao longo da primeira metade do século XIX, mas que teria vida longa na cultura brasileira: ele deveria ser um profundo conhecedor da sua ciência, dotado de boa cultura geral e facilidade de expressão, deveria mostrar interesse indistinto pela saúde de pobres e ricos e, sobretudo, encarar a sua profissão como um verdadeiro sacerdócio. A lenta e gradativa consolidação dessa imagem junto aos brasileiros dependeu, não se deve esquecer, da estruturação institucional da medicina. Foi somente na medida em que o número de profissionais formados aumentou e em que se criaram meios para formá-los em solo nacional, que a categoria ganhou força, organizou-se e passou a melhor controlar os seus membros, legitimando a sua autoridade como portadora da verdade sobre a doença e sobre a cura. Por sua vez, foi amparada nessa crescente autoridade que essa mesma categoria passou a cobrar, com cada vez mais força, uma maior atenção dos poderes públicos às suas necessidades (melhores faculdades, mais hospitais, mais participação nas políticas de saúde pública, melhor controle do exercício da profissão etc.).

Ambos os processos, no entanto, são insuficientes para explicar o sucesso da medicina no Brasil a partir do século XIX - no Brasil e de certa maneira pelo Ocidente (Foucault, 2001, 1984). Dito de maneira mais clara: nem a consolidação da imagem do profissional de saúde nem a melhor organização da corporação 
podem, isoladamente, explicar de forma convincente a imensa presença e penetração do saber médico em solo brasileiro, o seu gradativo mas poderoso e longo domínio sobre os corpos da população. Para entender tamanha e tão rápida ascensão é preciso ampliar um pouco a perspectiva e incluir aí as estratégias de organização da sociedade local que tiveram início com o desembarque do monarca em 1808, estratégias civilizatórias, como então se dizia.

Uma das primeiras atitudes de D. João VI, ao instalar-se no Rio de Janeiro em 1808, foi ordenar ao físico-mor Manoel Vieira da Silva que fizesse, juntamente com outros profissionais, um estudo sobre o estado sanitário da cidade, que apontasse as principais fontes geradoras de doenças e os meios de removê-las. Meses depois, em resposta à demanda do monarca, Vieira da Silva elaborou um relatório no qual apontava dois tipos de fatores causadores dos tais males que afligiam a capital: os naturais e os não naturais. No primeiro grupo, encontrava-se o clima (quente e úmido) e a geografia da cidade (cercada de pântanos exalantes de miasmas e circundada por morros que dificultavam a circulação dos ares). No segundo grupo - aquele que reunia os fatores que sendo obra dos homens, podem receber a sua extinção da mão dos homens -, o médico incluía a contaminação do ar pelas sepulturas instaladas em igrejas e em cemitérios improvisados e mal cuidados, a péssima qualidade dos alimentos disponíveis para consumo, a insalubridade das ruas e do porto e, ainda, o descaso de que era vítima a atividade do médico diplomado, quase um desconhecido da população. Diante de tal quadro, aconselhava Vieira da Silva, o mais prudente e proveitoso seria promover um controle sanitário da cidade levado a cabo pelos que mais entendiam do assunto, os médicos (Silva, 2008).

Atendendo à sugestão do médico, D. João VI criou, em 1809, o cargo de provedor-mor de Saúde da Costa e Estados do Brasil. O ocupante desse posto, por sinal o próprio Vieira da Silva, 
deveria coordenar todos os esforços referentes à manutenção da higiene pública. Os termos do decreto, respondendo ao apelo do físico-mor, consideram que a matéria em questão é

[...] muito própria de pessoas versadas na ciência da medicina por terem toda a inteligência daquela parte que tem por objeto a conservação da saúde e os conhecimentos necessários para dar providências adaptadas aos casos que ocorrerem nesta matéria de tanta importância [...]. (apud Machado, 1978, p.164)

A criação da Provedoria atendia uma das exigências da Fisicatura: supria a carência de um órgão que, controlado por médicos, elaborasse e coordenasse a política sanitária da Corte e do país; sua atuação, no entanto, muito deixou a desejar. Ao longo do período em que esteve sob a coordenação do Dr. Manoel Vieira da Silva, o órgão pouco contribuiu para aumentar a participação da classe médica nos processos de conhecimento e higienização da cidade e de seus habitantes. Igualmente irrisória foi sua atuação em favor da categoria: não promoveu a implantação do ensino médico universitário, não editou uma única revista ou jornal especializados e nem, tampouco, intensificou o combate ao charlatanismo. Em 1828, a instituição, em decorrência da extinção do cargo de físico-mor, passou a ser controlada pela Câmara Municipal. Por intermédio de seus fiscais, cabia a esse novo gestor inspecionar as boticas, o comércio de drogas e gêneros alimentícios, promover a limpeza dos logradouros públicos e controlar o exercício da profissão médica. Mais uma vez, desmedicalizava-se a política sanitária da cidade, excluindo a classe médica das instâncias decisórias do setor.

A categoria, agora organizada em torno da Sociedade de Medicina e Cirurgia, reagiu de imediato ao recuo. Inúmeras foram as suas críticas a essa nova política de higiene pública, críticas que ganhavam cada vez mais relevo à medida que os fiscais da 
Câmara mostravam-se incapazes de controlar as muitas epidemias que assolavam a capital: a febre de macaco, entre 1828 e 1835; a varíola, em 1834-1835; a gripe, em 1835; o sarampo, em 1834-1835; e a febre amarela, em 1828 e em 1839-1840. Aproveitando o clima de quase pânico que se gerou entre os habitantes e os administradores da cidade, os médicos procuraram explorar a incompetência dos fiscais da Câmara para promover a higiene das ruas, para controlar a qualidade dos alimentos, para fiscalizar o porto, para controlar a atividade da cura, para vigiar as boticas, enfim, procuraram explorar a incapacidade dos fiscais de formular uma política sanitária eficiente e abrangente. Os doutores, porém, não se detiveram aí. Paralelamente às críticas, trouxeram à luz o seu projeto alternativo para a higienização do espaço urbano, um projeto amplo que muito prometia à administração da cidade.

Recordemos que nesta época, década de 1830, a corte, o laboratório administrativo do país, vivia uma fase especialmente conturbada, pois a população crescera muito e de forma desordenada, o que produziu efeitos devastadores sobre a saúde pública. Conturbada, também, porque a tensão política era grande, os criminosos e ociosos eram muitos, a prostituição se alastrava rapidamente, em suma, porque não eram poucos os focos de desordem social. Lembremos, ainda, que, no mesmo período, se intensificam os esforços da administração local destinados a formar os habitantes da capital, a dotá-los de hábitos ordeiros e produtivos. ${ }^{9}$ Foi em meio a esse cenário de mudanças e ajustes que a corporação médica apresentou o seu projeto de higienização e organização do espaço urbano, o seu projeto de uma sociedade idealmente salubre e com corpos disciplinados. O Dr. Cruz Jobim, em 1836, no discurso de abertura do seu curso de

9 Acerca do processo civilizatório que se desencadeia no Rio de Janeiro a partir de 1808, ver: França (1999). 
Medicina Legal, ao explicar aos seus discípulos a utilidade do saber médico, fornece-nos uma ideia aproximada do quão audacioso era tal projeto:

Seria restrita a utilidade das ciências médicas e naturais, que têm por objeto o conhecimento profundo do organismo e dos corpos que exercem sobre o nosso qualquer influência, se tivessem por fim só fazer-nos conhecer a natureza das moléstias e os meios de curá-la ou preveni-la em cada membro da sociedade. Estes conhecimentos tornam-se mais importantes e necessários à medida que esta ciência aplica-se às necessidades do corpo social [...]. É da medicina e das ideias que ela fornece que os legisladores de todos os países têm procurado tirar os fundamentos de grande número de leis. Tanto mais válidas e estáveis quanto elas têm por base o conhecimento da natureza humana e das suas verdadeiras necessidades [...]. (Jobim, 1836, v.II, p.20)

Dois eram os principais objetivos desse ousado empreendimento da corporação médica. Em primeiro lugar, conhecer pormenorizadamente as cidades e, a partir daí, formular políticas sanitárias racionais e competentes, cuidar, em suma, do corpo social. Para tal, várias medidas vieram a ser tomadas: comissões permanentes, nomeadas pela Sociedade de Medicina, organizaram tabelas demográfico-sanitárias e quadros necrológicos do Rio de Janeiro (alvo inicial da intervenção); membros da mesma sociedade ofereceram consultas gratuitas e distribuíram remédios ao povo carente, de modo a atraí-lo para investigar suas doenças e seu modo de vida; grupos de médicos percorreram as ruas da cidade e promoveram um pormenorizado levantamento dos possíveis focos de insalubridade; e, principalmente, inúmeros relatórios foram encaminhados às autoridades cobrando medidas e sugerindo soluções para a resolução dos problemas de higiene da capital e, posteriormente, do país. 
Em segundo lugar, combater certos vícios entranhados no modus vivendi dos brasileiros e, ao mesmo tempo, promover entre eles a adoção de hábitos mais saudáveis e produtivos, sobretudo em relação ao trato e uso do corpo. Tal objetivo interessa aqui em particular, pois ele se articula intimamente àquelas estratégias de vigilância - e de indução à autovigilância - e controle do corpo que, desde então e num crescente, se tornaram sobremodo presentes no cotidiano da sociedade brasileira e passaram a ter uma palavra, por vezes decisiva, nos modos do brasileiro encarar o próprio corpo. O que esperar do corpo? Que vícios devemos evitar para melhor conservá-lo? Os prazeres devem ser limitados para que o corpo não se ressinta? O que comer? $\mathrm{O}$ que vestir? De que modo e onde morar? Que cuidados tomar quando o corpo é abatido por um mal qualquer? Essas e outras angústias sobre a melhor maneira de evitar as doenças e manter o corpo saudável, produtivo, atraente e longevo passaram crescentemente a atormentar a alma dos brasileiros, concomitante à certeza de que os médicos eram os mais capazes de aplacá-las.

O médico, desde então, atuando no interior das casas, dos colégios, das prisões, dos clubes, das escolas e de um sem número de outros espaços sociais, deu um impulso decisivo ao amplo processo de mudança de hábitos que experimentaram as famílias brasileiras, as urbanas, sobretudo, ao longo do século XIX e XX. A abertura das casas para a vida exterior, a alteração do seu regime de funcionamento, a reformulação do cotidiano feminino, o enfraquecimento da autoridade paterna, em suma, aquilo que muitos historiadores denominaram europeização dos hábitos ou modernização dos costumes, contou com a ativa participação dos doutores em medicina, com o seu empenho em destronar os supostamente insalubres hábitos herdados do passado colonial e introduzir uma nova economia no trato com o corpo, mais produtiva, ordeira e racional - científica, como aprendemos a acreditar com o passar do tempo. 
De certo modo, na sua ânsia por se afirmarem como os senhores da verdade sobre a doença e a cura, os médicos sonharam nesta época com um corpo - social, inclusive - livre de toda sorte de patologias, físicas e morais. Foi em nome dessa sociedade higienizada que opinaram sobre a organização das instituições, sobre a melhor maneira de controlar e asseptizar a prostituição, sobre a educação das crianças e dos jovens, sobre a limpeza dos logradouros públicos e dos estabelecimentos comerciais e até mesmo sobre a alimentação e a vestimenta de homens, mulheres e crianças. Foi em nome dela que procuraram, e em larga medida tiveram êxito, moldar os corpos tupiniquins, ou melhor, moldar a relação do brasileiro com seu próprio corpo. Afinal, eram tempos (?) em que se acreditava nos poderes ilimitados da medicina, nos poderes ilimitados dos ditos saberes científicos.

\section{O corpo jovem}

É certo que, nestes quase 200 anos de existência e autoafirmação, o saber sobre o corpo desses esperançosos doutores não levou nem ao conhecimento da tal natureza humana e do melhor modo de preservá-la, nem à estipulação de regras mais adequadas e mais racionais para a organização da sociedade brasileira. ${ }^{10}$ Por sorte da categoria, porém, cada vez menos a sociedade os interrogou acerca de tão espinhosos temas. A expectativa dos "leigos" em relação a eles era outra; o homem comum dispôs-se a detalhar a sua vida para os doutores, a ouvir suas indiscretas opiniões e a acatar as prescrições de médicos e psiquiatras, desde que isso trouxesse consigo a esperança, não de alcançar o conhecimento da natureza humana ou de viver em uma sociedade livre

10 Sobre a expansão da medicina no século XX, cf. Rosen (1980) e Brownlee (2009). 
de tensões, mas de simplesmente ter um corpo mais duradouro e prolongar ao máximo os vigores (e belezas) da juventude.

Para pesar de alguns, no entanto, a realização - um pouco torta, é verdade - do sonho oitocentista de estabelecer a supremacia do discurso médico naquilo que tange ao relacionamento do indivíduo com o seu corpo coincide com dois outros processos não muito alvissareiros para os doutores. É verdade que a gradativa higienização da sociedade trouxe consigo a cura ou controle de uma série de males que atazanavam há séculos a vida dos humanos - recordemos, a título de exemplo, dos ganhos trazidos pela vacinação em massa, pela assepsia dos ambientes relacionados ao tratamento e cura das doenças ou dos impactos sobre a saúde das populações proporcionados pela elaboração de certas drogas - e propiciou mais longevidade àqueles que podiam ter acesso aos serviços de saúde. Foi graças, sobretudo, a tais ganhos, constantemente renovados, que os doutores de toda casta alcançaram relativo êxito na sua missão de higienizar a sociedade, e que grande parte das normas de que os indivíduos passaram a lançar mão para organizar a sua vida cotidiana se impregnou de recomendações higiênicas. Está longe de ser por acaso, por exemplo, que a Internet tenha mais sites com dicas de saúde e bem-estar do que com conteúdo pornográfico. Hoje é mais fácil as crianças e jovens serem aliciados por um produto farmacêutico, um alimento funcional, uma vitamina ou um chá purificante, do que por um artigo erótico. Não é tampouco por acaso que os grandes jornais, nos últimos tempos, passaram a dedicar páginas, seções e mesmo cadernos inteiros, com dicas e reportagens sustentadas na opinião dos indefectíveis "doutores" e "especialistas", voltados para a saúde e o "equilíbrio" físico e metal dos leitores. Estamos, em suma, como sonharam os médicos do Oitocentos, empesteados pelas "verdades médicas".

Mas os supostos avanços tiveram, também, resultados perversos que não estavam previstos no sonho médico de produ- 
zir um corpo inteiramente medicalizado. Eles ampliaram, por exemplo, o padrão de exigência dos usuários dos serviços médicos: as cobranças por mais e mais longevidade se intensificaram e, como se isso não bastasse, passaram a vir acompanhadas de uma necessidade suplementar, a tal qualidade de vida - quantidade com qualidade. Para piorar a situação, essas crescentes demandas, incertas e difíceis de serem atendidas, coincidiram com aquilo que convencionalmente se tem denominado crise dos paradigmas científicos, isto é, a disseminação do sentimento de que a ciência é incapaz de ocupar o lugar outrora ocupado pela religião e de dar respostas satisfatórias às nossas inquietações sobre o mundo, inclusive para aquelas relacionadas ao corpo, à sua condução e à sua conservação.

Esses resultados perversos, potencializados por uma crise sem precedentes do conhecimento científico, trouxeram de volta um velho problema que parecia há muito superado: a concorrência dos outrora denominados charlatões. O nome mudou, é certo, não se fala mais em charlatanismo, mas em medicina complementar, medicina alternativa ou, ainda, medicina integrativa. Os charlatões também não existem mais, os novos atores são acupunturistas, fisioterapeutas, terapeutas de todo tipo e um sem número de outros profissionais, ansiosos por questionar e complementar, com legitimidade, o saber e a prática médicos. Diversamente dos competidores de antanho, estes de agora passaram pelos bancos das universidades e, dentro do possível, adotaram a nomenclatura e os procedimentos ditos científicos, ou seja, buscaram, ao menos aparente e tangencialmente, legitimar-se dentro dos critérios exigidos pelos discursos institucionalizados sobre o corpo, pelo discurso médico, nomeadamente (Aldridge, 2004; Kelner, Wellman, 2000; Natelson, 2008; WHO, 2005).

É, por certo, a concorrência desses competidores chancelados pelo saber universitário - que os médicos insistem que encaremos como uma variância renovada do velho charlatanismo - que 
tem motivado a categoria no sentido de, mais uma vez apelando aos poderes do Estado, tentar aprovar leis que proíbam ou submetam à autoridade e à chancela médica os muitos diagnósticos, terapias e intervenções destinados ao corpo propostas e controladas por não médicos. Uma rápida consulta ao polêmico Ato Médico, vetado há pouco pela presidência mas ainda tema de acaloradas discussões, dá a dimensão do que está em disputa:

Art. 1ํ $\mathrm{O}$ exercício da medicina é regido pelas disposições desta Lei.

Art. 2ㅇ objeto da atuação do médico é a saúde do ser humano e das coletividades humanas, em benefício da qual deverá agir com o máximo de zelo, com o melhor de sua capacidade profissional e sem discriminação de qualquer natureza.

Parágrafo único. O médico desenvolverá suas ações profissionais no campo da atenção à saúde para:

I - a promoção, a proteção e a recuperação da saúde;

II - a prevenção, o diagnóstico e o tratamento das doenças;

III - a reabilitação dos enfermos e portadores de deficiências.

Art. 3으 médico integrante da equipe de saúde que assiste o indivíduo ou a coletividade atuará em mútua colaboração com os demais profissionais de saúde que a compõem.

Art. 4o São atividades privativas do médico:

I - formulação do diagnóstico nosológico e respectiva prescrição terapêutica;

II - indicação e execução da intervenção cirúrgica e prescrição dos cuidados médicos pré e pós-operatórios;

III - indicação da execução e execução de procedimentos invasivos, sejam diagnósticos, terapêuticos ou estéticos, incluindo os acessos vasculares profundos, as biópsias e as endoscopias;

IV - intubação traqueal;

$\mathrm{V}$ - definição da estratégia ventilatória inicial para a ventilação mecânica invasiva, bem como as mudanças necessárias diante das intercorrências clínicas; 
VI - supervisão do programa de interrupção da ventilação mecânica invasiva, incluindo a desintubação traqueal; VII - execução da sedação profunda, bloqueios anestésicos e anestesia geral;

VIII - emissão de laudo dos exames endoscópios e de imagem, dos procedimentos diagnósticos invasivos e dos exames anatomopatológicos;

IX - indicação do uso de órteses e próteses, exceto as órteses de uso temporário;

$\mathrm{X}$ - prescrição de órteses e próteses oftalmológicas;

XI - determinação do prognóstico relativo ao diagnóstico nosológico;

XII - indicação de internação e alta médica nos serviços de atenção à saúde;

XIII - realização de perícia médica e exames médico-legais, excetuados os exames laboratoriais de análises clínicas, toxicológicas, genéticas e de biologia molecular;

XIV - atestação médica de condições de saúde, deficiência e doença;

XV - atestação do óbito, exceto em casos de morte natural em localidade em que não haja médico.

E mais adiante, lê-se:

Art. 5o São privativos de médico:

I - direção e chefia de serviços médicos;

II - coordenação, perícia, auditoria e supervisão vinculadas, de forma imediata e direta, a atividades privativas de médico; III - ensino de disciplinas especificamente médicas;

IV - coordenação dos cursos de graduação em medicina, dos programas de residência médica e dos cursos de pós-graduação específicos para médicos.

Parágrafo único. A direção administrativa de serviços de saúde não constitui função privativa de médico. 
Art. 6o A denominação de "médico" é privativa dos graduados em cursos superiores de medicina e o exercício da profissão, dos inscritos no Conselho Regional de Medicina com jurisdição na respectiva unidade da Federação.

Art. 7ํㅡㄹeende-se entre as competências do Conselho Federal de Medicina editar normas sobre quais procedimentos podem ser praticados por médicos, quais são vedados e quais podem ser praticados em caráter experimental. (Brasil, 2013a)

A cautela dos médicos não é desmedida, ao menos do ângulo de uma categoria ciosa do seu secular controle sobre a produção da verdade relacionada ao corpo. $\mathrm{O}$ avanço das terapias alternativas é não somente notável como coloca em cena mais uma vez um domínio que, a seu modo, era conhecido dos colonos dos séculos XVI, XVII e XVIII, aquele relacionado aos males da alma e aos seus impactos sobre o corpo. É o império das patologias psicossomáticas, acerca das quais os médicos têm ainda pouco a dizer, mas que parecem ser velhas conhecidas dos iogues, dos neurolinguistas, dos terapeutas holísticos e de um punhado de outros agentes da cura surgidos nas últimas décadas. Daí as dezenas de tratamentos disponíveis no mercado para aqueles males que assolam o corpo, gerando dor e desconforto, mas que parecem não prover dele; aqueles males que, em última instância, remetem a uma espécie de desvio moral, de má condução da alma, que precisa de uma intervenção específica - moral, espiritual, sentimental, sobretudo não limitada ao corpo físico - para ser corrigida.

Ao lado dessas doenças da alma que arrastam o corpo consigo, os médicos se depararam com outro território ainda pouco conhecido: aquele relativo às mudanças corporais de natureza estética, ou melhor, relativo à valorização de parâmetros estéticos como indicativos de saúde e longevidade. O que está em causa aqui é a produção de um corpo ideal, do ponto de vista 
da beleza, mas também da operacionalidade social (mais magros, mais ágeis, mais produtivos...). Há, é certo, uma parcela deste território inteiramente dominada pelos médicos: aquele das cirurgias estéticas. ${ }^{11}$ Todavia, em parcelas vizinhas desse território, a sua presença e autoridade é relativa, constantemente questionada e, ao que tudo indica, decrescente. É o reino em que proliferam os nutricionistas e seus regimes variados, os tatuadores com suas intervenções artísticas, os personal trainers e seus programas milagrosos, as esteticistas, os massagistas, os odontologistas estéticos e tantos outros, todos portadores de uma sua verdade sobre o corpo, e com métodos próprios para modelá-lo segundo o gosto do cliente - gosto socialmente determinado, bem entendido.

Tem-se, pois, uma situação paradoxal: por um lado, nunca antes o saber médico sobre o corpo teve tamanho impacto e penetração - dos check-ups privados às grandes políticas de saúde pública, a presença do médico e de suas prescrições como intermediários entre o indivíduo e o seu corpo generalizou-se no Brasil entre os séculos XIX e XX; por outro lado, por razões sociais diversas, entre as quais uma sutil mas profunda falência da crença iluminista na ciência e uma crescente e persistente cobrança por melhores resultados - melhores performances -, o saber médico viu-se questionado por todos os lados - afinal, muitas foram as promessas frustradas -, o que lançou suas práticas sob suspeita e abriu caminho para a emergência de uma série de competidores interessados em, no mínimo, partilhar com os doutores filhos de Hipócrates o direito de produzir uma verdade sobre o corpo.

11 Cf. Loeb (1993); González-Uolla (1985); Santoni-Rugiu (2007); Wolfenson (2005). 


\section{Língua no Brasil: variação e multilinguismo ${ }^{1}$ \\ Cristina Carneiro Rodrigues ${ }^{2}$}

Este capítulo tem como objetivo examinar noções arraigadas no imaginário do brasileiro sobre a língua por ele falada e questionar algumas ideias amplamente aceitas a seu respeito. A primeira delas é a crença de que o português sempre foi a língua do país; a segunda é a de que do Oiapoque ao Chuí fala-se uma língua homogênea; a discussão sobre a heterogeneidade do português leva ao terceiro ponto: a questão do preconceito linguístico.

Ao contrário do que muitos pensam, a chegada de Pedro Álvares Cabral ao Brasil não significou fincar aqui as raízes da língua portuguesa. Quando os portugueses decidiram enviar ao rei uma nau com a notícia do "achamento" da terra, deixaram aqui dois degredados, para que aprendessem a língua dos habitantes da terra, e, no futuro, atuassem como "línguas", a maneira pela

1 Agradeço ao colega Sebastião Carlos Leite Gonçalves pela generosa interlocução e pelas valiosas sugestões.

2 Professora voluntária do Departamento de Estudos Linguísticos e Literários e do Programa de Pós-Graduação em Estudos Linguísticos do Instituto de Biociências, Letras e Ciências Exatas, Universidade Estadual Paulista "Júlio de Mesquita Filho” (Unesp), São José do Rio Preto (SP). E-mail: cristina@ ibilce.unesp.br. 
qual denominavam os intérpretes. De acordo com Rodrigues (2006), estima-se que, na época, viviam no território cerca de cinco milhões de indígenas, falantes de 1.175 línguas, duas delas usadas em quase toda a costa atlântica: o tupi, no litoral onde hoje está o estado de São Paulo, e o tupinambá, falado do atual Rio de Janeiro até a foz do rio Amazonas. Como as línguas eram muito semelhantes entre si, o contato linguístico entre indígenas e europeus foi facilitado, pois bastava aos estrangeiros aprenderem uma delas para se comunicar por todo o litoral. Esse fato não favoreceu o estabelecimento da língua portuguesa, nem exigiu que se criasse um pidgin - sistema de comunicação simplificado e "precário" utilizado exclusivamente para contato entre falantes que não têm língua em comum - como ocorre em inúmeras situações de contato linguístico pelo mundo entre habitantes da terra e colonizadores.

Tendo em vista que a língua aprendida em um ponto da costa podia servir em quase todos os outros lugares ao longo dela e que, no início, a colonização portuguesa se ateve ao litoral, a língua indígena foi amplamente utilizada. Nem mesmo a catequização, promovida pelos jesuítas a partir de 1549, favoreceu a disseminação do português no Brasil, porque os religiosos também buscavam dominar a língua falada na região. Desde que chegaram, os jesuítas, além de aprenderem a língua da terra, começaram a traduzir para a língua indígena o catecismo, tanto que as primeiras traduções feitas no Brasil tiveram o português como língua de partida. Em 1595 publicou-se, em Coimbra, a Arte da gramática da língua mais usada na costa do Brasil, obra na qual o padre José de Anchieta sistematizou a língua que chamaram de brasílica. Em 1618 foi publicado, em Lisboa, o Catecismo da língua brasílica, ${ }^{3}$ uma adaptação da doutrina cristã para os indígenas, ou seja, instrumento de trabalho na catequese.

3 Disponível em: <http://biblio.etnolinguistica.org/barbosa-1952-catecismo>. Acesso em: dez. 2013. 
A colonização do Brasil se deu de diferentes formas; a costa de São Paulo e a do Maranhão foram, como extremos no domínio português, as que menos receberam imigrantes e onde se produziram as mais intensas situações de mestiçagem. Em outros lugares, do Rio de Janeiro até o Nordeste, as relações entre indígenas e europeus não foram tão pacíficas, e povos falantes de tupinambá começaram a ser dizimados já ao longo do século XVI.

Na capitania de São Paulo, houve interação entre os índios tupi e os portugueses, tanto no litoral como no interior. Sendo os primeiros colonizadores do sexo masculino, eles procriaram com as mulheres da terra, e seus filhos, muitas vezes eram falantes exclusivamente das línguas de suas mães. Com o passar do tempo, os tupi foram se extinguindo enquanto povo independente, os mamelucos passaram a exercer as atividades dos pais, novos portugueses chegaram à terra, e a língua falada por essa nova sociedade foi se alterando. Essa língua, chamada por Rodrigues (1996) de língua geral paulista, foi usada do século XVI ao XVIII pelos habitantes da região, e foi levada pelos bandeirantes em suas incursões pelo interior dos estados brasileiros (Minas Gerais, Goiás, Mato Grosso, Paraná, Rio Grande do Sul).

Também na Amazônia e no Maranhão desenvolveu-se uma população de mamelucos que falava a língua das mães tupinambás, mas o processo foi desencadeado posteriormente, no século XVII, quando foi criado o Estado do Maranhão e Grão-Pará. De modo semelhante ao que ocorreu em São Paulo, a língua foi se distanciando do tupinambá, e a língua geral amazônica penetrou no território pelos rios amazônicos.

Há, portanto, no Brasil, até o século XVIII, uma situação de multilinguismo generalizado: utilização do tupi ou tupinambá na catequese, predomínio do português na área costeira central, do espanhol na costa sul - área atribuída, no tratado de Tordesilhas, à coroa espanhola -, emprego de línguas gerais em São Paulo e do Maranhão à Amazônia, e uso de centenas de lín- 
guas indígenas pelo interior do Brasil. O quadro é diversificado quando numerosas línguas africanas aqui aportaram, trazidas pelos africanos escravizados para trabalhar, em um primeiro momento, nas grandes propriedades açucareiras do Nordeste, depois em variados serviços por todo o território. Completando o cenário, outras línguas europeias foram utilizadas no período colonial, ainda que por períodos mais ou menos curtos em locais bem determinados: o francês, na costa do Rio de Janeiro, de 1555 a 1567 (França Antártica) e no Maranhão, de 1612 a 1615 (França Equinocial); e o holandês, durante a ocupação do Nordeste, entre 1630 e 1655.

A língua da administração e de comunicação com a metrópole, entretanto, sempre foi o português; língua de prestígio - já sistematizada pelas gramáticas de Fernão de Oliveira, de 1536, e de João de Barros, de 1540 - é a do período de riqueza de Portugal das grandes navegações, e empregada por escritores, poetas, dramaturgos, como Sá de Miranda, Camões, Gil Vicente, Antonio Ferreira.

Após um período de dominação espanhola, findo em 1640, Portugal viveu um regime de monarquia absolutista, durante o qual os reis atribuíram muito poder a ministros. Dentre eles, o mais conhecido foi Sebastião José de Carvalho e Melo, o Marquês de Pombal, ministro de D. José, rei de Portugal entre 1750 e 1777. Pombal tinha como projeto fazer com que as riquezas das colônias beneficiassem Portugal, e combateu poderes considerados paralelos, como a Companhia de Jesus. Em 1758, buscando solapar o poder dos jesuítas na colônia, impôs, por decreto, o uso de português como língua de ensino e, em 1759, acabou por expulsar a Companhia de Jesus de todos os domínios portugueses.

Pesquisadores, como Callou et al. (2006, p.266), não estão convencidos de que o decreto de Pombal tenha sido decisivo para a extinção do uso de outras línguas no Brasil. Como argu- 
mento, consideram a estrutura educacional do Brasil colonial: décadas após o decreto, o sistema ainda era incapaz de cumprir a determinação de ensinar português a toda população. Apenas homens brancos e pardos socialmente aceitos tinham algum acesso à instrução pública. Estima-se que, em 1818, apenas 2,5\% dos homens livres tinham acesso à escolarização em São Paulo (Vitral, 2001, p.306).

Certamente o decreto não foi o responsável pelo fim da utilização da língua geral amazônica, que continuou a ser amplamente utilizada até o século XIX. Quando se instituiu a unidade política na região, o estado do Maranhão e Grão-Pará, de acordo com Freire (2004, p.247), a metrópole e a Igreja intervieram para buscar também uma unidade linguística. Do multilinguismo que caracterizava a região, passou-se ao bilinguismo, em que uma das línguas era a vernácula, a língua indígena, e a outra, a língua geral; após um longo processo, a língua geral foi adotada, ou seja, imperou o monolinguismo. Essa política, por um lado, facilitou a ocupação da Amazônia, mas, por outro, contribuiu para a extinção de muitas línguas, porque permitiu a passagem do monolinguismo inicial na língua da comunidade indígena para o monolinguismo primeiro em língua geral, depois em português. Essa passagem ocorreu após a divisão do Grão-Pará em duas províncias, Pará e Amazonas, em 1823, subordinadas ao Brasil, independente de Portugal desde 1822. Contribuíram para a difusão do português as migrações para a Amazônia, especialmente de nordestinos para a produção da borracha; o sistema de navegação baseado na navegação a vapor; e o processo de urbanização. As línguas indígenas tinham seu espaço nas aldeias, mas, na medida em que os homens saíam para trabalhar, deparavam-se com o português utilizado nas zonas urbanas; se, em um primeiro momento a língua geral articulou esses dois espaços, ao longo do tempo ela foi abandonada em favor do português. 
Freire (2004) não descreve uma convivência harmônica entre as línguas e culturas em contato na Amazônia. Ao contrário, havia conflito; a língua geral era discriminada como língua dominada, falada por índios e mestiços. O português era a língua da alfabetização e do sistema administrativo, o que contribuía para que a população lhe atribuísse maior peso cultural e político. Além disso, dois eventos, a Cabanagem e a Guerra do Paraguai, concorreram para acelerar o processo de diminuição dos falantes da língua geral. O movimento dos "cabanos" ou "tapuios", insatisfeitos com suas condições de vida e trabalho, foi duramente reprimido. Calcula-se que entre 30 e 40 mil indivíduos morreram nos cinco anos de repressão (1835-1840), grande parte deles falantes de língua geral. Ainda que a proporção seja muito menor, a morte de indígenas recrutados para a Guerra do Paraguai (1864-1870) também contribuiu para o decréscimo dos falantes da língua geral amazônica. Freire (2004) informa que o ano de 1850 marca o início da hegemonia do português, ou seja, quase um século após o decreto de Pombal.

A língua geral amazônica foi fartamente documentada, pois, entre 1838 e 1931, o Instituto Histórico e Geográfico Brasileiro (IHGB) organizou a busca sistemática de documentos históricos referentes ao Brasil e reservou um lugar importante para estudos linguísticos. $\mathrm{O}$ resultado dessas pesquisas, assim como relatos de viajantes que observaram o uso da língua geral foram sistematicamente publicados na Revista do IHGB. O mesmo não ocorreu com a língua geral paulista, não apenas pouco documentada, como muitas vezes confundida com a amazônica, até mesmo em sua denominação: nheengatu.

Alguns linguistas, como Barbosa (1998, p.231), lamentam que haja, por um lado, falta de fontes apropriadas para o estudo da linguagem utilizada no Brasil entre o século XVI e XIX, e, por outro, o desconhecimento sobre o contexto sociocultural do Brasil colonial. O problema apontado relaciona-se com o fato de que 
"a história social das línguas é um campo de conhecimento de caráter transdisciplinar ainda pouco explorado" (Freire, 2004, p.246). Isso se reflete nas afirmações de pesquisadores, como Castilho (2001, p.351), para quem ainda falta "o esclarecimento da língua efetivamente praticada pelos bandeirantes”. Mattos e Silva (2001, p.286-287) conjecturam-se "o que na documentação colonial se designa por usar a língua geral, falar a língua geral, saber a língua geral" não se refere a "um português simplificado, com interferências de línguas indígenas e também de línguas africanas", ou a "um português mal falado". Outros pesquisadores não duvidam de que a língua geral paulista tenha sido amplamente utilizada e buscam explicar as razões de seu abandono. Callou et al. (2006, p.270) asseveram que a vitória do português se deu por causa de uma

mudança na opção linguística da minoria branca e parda livre que falava uma das línguas gerais daquela época: eles abandonam, com o passar das gerações, a língua geral, usada na intimidade, em favor da língua portuguesa, primeiro na vida pública, depois estendida à familiar.

Considerando, entretanto, a extensão do território para onde os paulistas teriam levado sua língua geral, essa explicação não parece suficiente para esclarecer como uma língua falada em tantos lugares deixou de ser usada, restando dela tão poucos rastros, a ponto de hoje poucos saberem que foi empregada. Em áreas menos habitadas e onde não se estabeleceram núcleos populacionais efetivos, como Goiás e Mato Grosso, entende-se que ela não se tenha disseminado. Em Minas Gerais, a Guerra dos Emboabas, travada entre os paulistas que queriam o domínio do lugar e os portugueses (emboabas) e os oriundos de outras partes do Brasil que também desejavam aproveitar-se das riquezas minerais lá descobertas, ajuda a explicar porque a língua 
geral foi abandonada. Os confrontos se deram de 1707 a 1709 , e os paulistas perderam o controle da região, resultando no fim da expansão da língua por eles falada nessa parte do Brasil. Essa teria sido, de acordo com Vitral (2001, p.312), a vitória de uma língua considerada da civilização, a portuguesa, sobre a língua geral, associada à barbárie.

Quanto ao sul do Brasil, as pesquisas desenvolvidas por Oliveira $(1998,2001)$ apontam para dois ciclos de ocupação nos séculos XVII e XVIII: o dos paulistas e o dos açorianos. Em um primeiro momento, os paulistas foram para o litoral, onde fundaram Laguna, em Santa Catarina, "que passou a ser um centro difusor da língua e da cultura paulistas no século XVII e nos primeiros anos do século XVIII" (Oliveira, 2001, p.403). A partir de 1720, o foco do avanço paulista passa a ser o interior, quando as tropas de mulas iam de Sorocaba a Vacaria, passando por Lapa e Lages. A expansão da variedade paulista teria entrado em contato com outra variedade, a dos açorianos, que vieram para o Brasil atendendo aos interesses da Coroa Portuguesa, que pretendia conquistar e manter a margem esquerda do Rio da Prata. Os açorianos acabaram não ocupando a região das Missões, instalando-se no litoral catarinense e no centro-leste do Rio Grande do Sul. Ao analisar os mapas produzidos pelo projeto Atlas Linguístico-Etnográfico da Região Sul do Brasil (Alers), especialmente o de Santa Catarina e o do Rio Grande do Sul, Oliveira (2001) estabelece relações entre esses ciclos históricos e determinadas características linguísticas, especialmente as referentes ao sistema de tratamento ("tu" versus "você"). Oliveira apenas lembra que os paulistas não falavam homogeneamente o português. É possível que o avanço da urbanização no século XVIII tenha sido acompanhado pelo uso do português como língua de contato, pois pesquisadores, como Rodrigues (2006, p.148), estabelecem a metade do século XVIII como o final do domínio da língua geral paulista. 
Considerando ser relativamente recente o interesse por uma história social do português brasileiro - pois apenas em 1992 foi criado o Programa para a História da Língua Portuguesa (Prohpor), e o I Seminário para a História do Português Brasileiro realizou-se em 1997 - ainda há muitas perguntas a se responder. Entre as questões que parecem centrais a Jânia Ramos (1998, p.166) no estudo da "sócio-história do português brasileiro" estão: como explicar o sucesso do português no Brasil e como explicar as diferenças dialetais do território brasileiro.

A primeira questão parece ser a mais controversa no cenário dos estudos linguísticos, pois envolve entender como, de um panorama multilíngue do século XVI ao XVIII, o Brasil passa a ter o português como língua hegemônica, sendo esquecido que tanto as línguas indígenas (tupi e tupinambá) quanto as línguas gerais amazônica e paulista foram tão importantes no Brasil colonial. E mais do que explicar as diferenças dialetais, assunto de que a sociolinguística tem se ocupado desde o final dos anos 1960 no Brasil, a controvérsia gira em torno de como se formou o que hoje denominamos "português brasileiro", ou seja, qual é a origem do português falado no Brasil.

Em um primeiro momento, é necessário lembrar que há um preconceito generalizado em relação a línguas ágrafas, como as indígenas e as africanas. Assim, muitos explicam a hegemonia do português por suas qualidades inerentes, considerando que as línguas europeias seriam superiores às demais. $\mathrm{O}$ português seria uma língua estruturada, uma "língua de cultura", como enfatiza Houaiss (1992), enquanto as línguas indígenas, base para as gerais, seriam pobres e incapazes de expressar conceitos abstratos. Assim, o esquecimento de que línguas supostamente menos nobres foram amplamente usadas no Brasil pode estar relacionado à noção, também bastante difundida, de que há uma relação entre falar bem e pensar racionalmente. Como a língua é um dos elementos que compõem uma identidade nacional, construiu-se 
uma unidade linguística desde 1500, com base no português transformado na única língua dos brasileiros, desconsiderando a ampla difusão, no tempo e no espaço, da língua geral amazônica e da língua geral paulista, hegemônicas durante todo o período colonial em partes expressivas do que é hoje território nacional. (Freire, 2004, p. 33)

Seu silenciamento teria sido tão efetivo que descendentes de falantes da língua geral amazônica, passadas duas ou três gerações, ignoram a língua e o uso que seus avós dela fizeram. Freire associa esse esquecimento à construção de uma unidade territorial, apagando-se o fato de que foi apenas no segundo semestre de 1823 que o Grão-Pará, antes politicamente independente, integrou-se ao império.

O que sabemos ao certo é que o português incorporou um número considerável de palavras indígenas. De acordo com Rodrigues (1994, p.21), de uma amostra de cerca de mil nomes de aves, um terço (350) é oriundo do tupinambá; quanto aos peixes, em uma amostra de 550 nomes, quase a metade (225) veio da língua indígena; é grande também a quantidade de lugares, de plantas, de outros animais e de alimentos com essa origem. Esse tipo de contribuição lexical indica que o elemento indígena era predominantemente rural, não urbano.

Por outro lado, a contribuição lexical dos africanos foi mais marcante em relação a objetos e a manifestações de caráter religioso, indicando que atuavam tanto na zona rural quanto na urbana. O tráfico foi autorizado em 1549, mas não se sabe exatamente quando os primeiros escravos chegaram ao Brasil - João Ribeiro (1954, p.203) informa que sua vinda "deve datar pelo menos do ano de 1532”, informação ratificada, com a mesma reserva, por Prado Júnior $(1971)^{4}$ - nem exatamente

4 Prado Júnior (1971, p.37) diz: "não se sabe ao certo quando apareceram pela primeira vez no Brasil; há quem afirme que vieram já na primeira expedição oficial de povoadores (1532)". 
quantos foram. Sabe-se, entretanto, que, quando os africanos chegaram, encontraram um cenário já multilíngue. Com eles, numerosas línguas africanas aqui aportaram. Pessoa de Castro (2006) afirma ser difícil precisar, da quantidade de línguas africanas, quais foram faladas por cinco a oito milhões de indivíduos trazidos para o Brasil por mais de três séculos. Todos os documentos oficiais referentes ao tráfico foram queimados em 1891, e os relatos existentes sobre a vida dos escravos no Brasil não levavam em consideração sua proveniência nem mencionavam a língua que falavam. Baseada na hipótese de que o estudo do léxico de origem africana utilizado no português pode levar à língua que o originou, Pessoa de Castro (2006) buscou evidências linguísticas para suprir deficiências de informações históricas. Concluiu que, no Brasil, das línguas da África Ocidental (do Senegal à Nigéria), destacaram-se o iorubá e as línguas do grupo ewe-fon (ou eve-fon), como ewe (ou jeje), fon (ou daomeano), gun e mahi (ou maí) (Pessoa de Castro, 2006, p.105); e, da África Banto, território que vai da linha do Equador ao sul do continente, predominaram três línguas, o quicongo, o quimbundo e o umbundo (Pessoa de Castro, 2006, p.107). Para essa pesquisadora,

as línguas bantos foram as mais importantes no processo de configuração do perfil do português brasileiro, devido à antiguidade e superioridade numérica de seus falantes e à grandeza da dimensão, no tempo e no espaço, alcançada pela sua distribuição humana no Brasil colonial. (Pessoa de Castro 2006, p.108-109)

Inicialmente, os africanos escravizados vieram para trabalhar nas grandes propriedades açucareiras do nordeste, substituindo os indígenas, depois em variados serviços por todo o território. Eles atuaram em todos os ciclos econômicos do Brasil, do sul à Amazônia, nas plantações, nas minas, nas atividades extrativis- 
tas. Após a abertura dos portos em 1808, intensificam-se suas atividades nos núcleos urbanos.

Dados sobre a distribuição étnica da população brasileira indicam claramente que etnias não europeias predominaram no Brasil até o fim do século XIX. Mattos e Silva (2006, p.238) retomam dados coletados por outros autores para evidenciar que entre 1538 e 1850 cerca de $70 \%$ da população era formada por africanos, negros brasileiros, mulatos e índios integrados. A população não branca decresce entre 1851 e 1890, mas atinge expressivos $59 \%$, sendo que, dessa taxa, apenas $2 \%$ seriam de índios integrados. No final do século XVI, a presença africana $(42 \%)$ se estendia por todas as capitanias e ultrapassava o grupo dos indígenas (28\%) e o dos de origem europeia (30\%). Esses dados indicam que a ocupação territorial do Brasil não pode ter sido feita pela população branca. Então, a difusão do português também teria sido de responsabilidade dos africanos e de seus descendentes. Mattos e Silva (2000, p.23) fornece os seguintes argumentos para embasar a hipótese: sua presença maciça; sua atuação em todos os ciclos econômicos; sua mobilidade geográfica; e as múltiplas funções que exerceram na sociedade urbana e rural.

Essa argumentação esbarra em outra questão: qual é a origem da vertente popular do português falado no Brasil. De acordo com Castilho (2007, p.13), são três as teses mais debatidas pelos linguistas: a da "ancianidade de nossa língua", a da "emergência de uma nova gramática do português" e a "crioulística”. A primeira, levantada por filólogos nas décadas de 1950 e 1960, é a de que o português brasileiro seria uma continuação do português europeu, o que leva muitos a denominarem tese da deriva ou da evolução natural, pois as línguas mudariam ao longo do tempo seguindo um rumo que lhes é próprio. Essa tese foi parcialmente retomada por Anthony Naro e Marta Scherre (2007) que, desde a década de 1990, "garimparam" fatos do português europeu 
para evidenciar que algumas das supostas peculiaridades do português brasileiro são encontradas em Portugal. Assim, refutam a hipótese de que a língua que falamos seria o resultado de um processo de simplificação. Os dois principais traços analisados, frequentes na fala de brasileiros de todas as regiões, são:

(1) variação da concordância nominal e verbal; por exemplo, o uso do plural apenas no determinante do sintagma nominal, como em "as roda de madeira"; neutralização, ou falta de concordância de pessoa verbal, como em "eu fez"; falta de concordância entre sujeito e predicado, como "foi os meninos que fez";

(2) uso frequente de pronomes explícitos na posição de sujeito, como em "ele falou", que também ocorre em verbos com plural explícito (eles falaram) e sem plural explícito (eles falou).

Naro e Scherre (2007) não querem, com seus argumentos, insinuar que o português brasileiro e o português europeu trilharam os mesmos caminhos linguísticos; eles querem evidenciar que estruturas supostamente brasileiras são utilizadas em Portugal e que a diferença é quanto à frequência do uso, muito maior no Brasil, e na distribuição social, aqui amplamente empregadas por todas as classes sociais e, em Portugal, apenas no meio rural ou por pessoas com pouca ou nenhuma escolarização. Para os autores, as origens do português do Brasil são internas, mas uma "confluência de múltiplas motivações", tais como o colapso da norma devido a uma situação de menor pressão social, o contato com outras línguas, a aprendizagem informal do português, intensificou as mudanças, não a deriva propriamente dita.

A segunda tese é a de que, a partir do século XIX, o português brasileiro teria passado a construir uma nova gramática. Tarallo (1993b, p.70), ao "esboçar a emergência de uma gramática bra- 
sileira que, ao final do século XIX, mostrava claras diferenças estruturais em relação à gramática portuguesa", apresenta quatro grandes mudanças sintáticas para demonstrar a tese. A primeira é a preferência pelo sujeito pronominal pleno, com em "eu li", em lugar de "li". A segunda é em relação às estratégias de relativização, com o quase desaparecimento da construção padrão, como em "este é o homem com quem eu falei ontem", substituída pela variante cortadora, "este é o homem que eu falei ontem" ou pela estigmatizada copiadora ou com pronome-lembrete, "este é o homem que eu falei com ele ontem". A terceira refere-se à ordem sentencial, com a emergência da ordem rígida do sujeito anteposto ao verbo. A quarta mudança, relacionada às anteriores, é sobre o padrão sentencial em perguntas que eram, no século XVIII, quase categoricamente construídas com o verbo antecedendo o sujeito (como em "acabou o doce?") e passaram a ser eminentemente com o sujeito anteposto ao verbo (o doce acabou?). Kato (1993) menciona também o empobrecimento da morfologia flexional (ele $f e z$, nós $f e z$, eles $f e z$ ) e a perda do sistema de clíticos como objeto (uso de "eu vi ele", em lugar de “eu $o$ vi”). O conjunto das pesquisas realizadas evidenciaria que “o que ocorre não é um processo de 'deterioração da gramática', como pensam os escolarizados pela ótica prescritivista, mas uma reorganização interna coerente, uma mudança radical (paramétrica) na língua” (Kato, 1993, p.19). Essa gramática levaria também a construções de tópico, muito comuns na fala, em que o enunciado não se inicia com o sujeito, mas com um elemento chamado de "tópico", e é separado do que se segue, o "comentário”, por uma pausa, como em "o João, eu vi ele ontem”.

Refutada por Naro e Scherre (2007), a terceira tese é a de que as características do português brasileiro teriam origem crioula. Em situações de contato entre dois grupos que não falam a mesma língua, muitas vezes desenvolve-se um pidgin, língua de emergência e apenas com funções básicas, porque utilizada 
exclusivamente nas circunstâncias de contato. Serve às necessidades locais e específicas. Entretanto, quando as relações perduram, pode ocorrer a transmissão para uma segunda geração, o pidgin se criouliza. O processo de crioulização ocorreu em vários lugares do mundo marcados pela escravidão de populações africanas, como os crioulos de base portuguesa em Cabo Verde e São Tomé, o crioulo da Jamaica, de base inglesa, o do Haiti, de base francesa, o de Curaçao, de base espanhola.

De acordo com Tarallo (1993a), a tese remonta ao século XIX, quando Adolpho Coelho alegou a origem crioula do português. No final dos anos 1950, teria sido combatida por filólogos de prestígio, como Serafim da Silva Neto, Celso Cunha, Antenor Nascentes, mas foi retomada por pesquisadores contemporâneos, como Guy (1981, apud Tarallo, 1993a).

Outros linguistas não assumem a tese da crioulização do português propriamente dita, pois consideram que vários fatores teriam inibido a formação de um crioulo no Brasil. Dentre eles, para Lucchesi (2009), está o fato de a população branca no Brasil não ter sido tão reduzida quanto na Jamaica, o que possibilitava maior acesso à língua portuguesa, mas o fator decisivo teria sido a miscigenação racial. Os mestiços eram em grande número e, como tinham possibilidade de ascensão social, tendiam a buscar sua integração na cultura do grupo dominante, ou seja, assimilar seus padrões linguísticos. O autor explica a formação da atual realidade linguística brasileira por uma transmissão linguística irregular, ou seja, um aprendizado impróprio de segunda língua, que se caracterizaria pela simplificação de estruturas gramaticais. Africanos e índios integrados teriam aprendido precariamente o português e um "modelo defectivo de português como língua segunda nas gerações seguintes" teria desencadeado o processo de formação do atual português em suas "variedades populares" (Lucchesi, 2009, p.71). Além disso, "o modelo de língua transmitido teria sido constantemente enfraquecido e 
diluído, devido às renovações sucessivas do contingente de escravos africanos" (Baxter; Lucchesi, 1997, p.72). Assim, ao defenderem a origem crioula do português, Baxter e Lucchesi (1997, p.74) consideram "melhor contemplar a crioulização como um processo que pertence a um contínuo de gêneros de transmissão" da língua do grupo dominante por parte do grupo dominado, que a altera e a simplifica, possivelmente devido à influência de sua língua materna.

A linguista Rosa Virgínia Mattos e Silva, seguindo uma orientação histórica ou sócio-histórica, defende tese similar, fundamentada na demografia histórica e na escolarização. Baseada nos dados acima mencionados, de que entre 1538 e 1850, cerca de $30 \%$ da população era formada por brancos brasileiros e europeus, os demais $70 \%$ adquiriram a língua portuguesa "em situação de aquisição imperfeita ou de aprendizagem irregular", ou seja, "sem nenhum controle normativo-prescritivo" da escolarização, fossem eles falantes de línguas indígenas ou de línguas africanas (Mattos e Silva, 2006, p.239). Esse grande contingente populacional teria, portanto, adquirido o português nas circunstâncias da oralidade e seriam responsáveis não só pela expansão territorial do Brasil, como também pela concomitante difusão do português brasileiro "na sua face majoritária, a popular ou vernácula" (Mattos e Silva, 2006, p.246). Os dados sobre alfabetização reforçam o argumento: em 1872, 20\% dos homens livres eram alfabetizados, enquanto entre os escravos, 99,9\% eram analfabetos. Sem dúvida, havia uma enorme distância entre a elite letrada e a grande massa de analfabetos.

Para Naro e Scherre (2007, p.67), o uso do termo "crioulização" para se referir ao processo de formação do português no Brasil é um "equívoco". Para os autores, a aprendizagem de segunda língua em fase adulta que predominou por toda a história do Brasil, mesmo antes da chegada dos escravos, acelerou e exagerou "as tendências iniciais durante o processo de 
nativização da língua portuguesa pelas comunidades das mais diversas bagagens culturais" (Naro; Scherre, 2007, p.53). O termo nativização é por eles utilizado para se referir à passagem de língua não nativa a nativa, não a um processo de simplificação. Assim, a língua de fora - no caso, a portuguesa - torna-se a língua nativa da comunidade, substitui as línguas maternas anteriores dos indivíduos. E, de acordo com os autores, o português já teria chegado ao Brasil com as características variáveis que pesquisadores como Lucchesi classificam como crioulas ou semicrioulas. No Brasil, devido às condições de multilinguismo, de aquisição por adultos, a comunidade de fala não sofreu a pressão normativa que pesava sobre uma comunidade de fala estável, como a de Portugal, e desenvolveu e manteve o uso de formas não prestigiadas nas variedades do português europeu. Assim, o português brasileiro não seria uma simplificação, não seria uma língua com influência africana, seria o "português com suas raízes originais, rurais e populares, transplantado para uma terra mais fértil e consequentemente com um desenvolvimento mais intenso" (Naro; Scherre, 2007, p.181).

Cada uma das teses sobre a origem do português brasileiro postula um caminho para explicar suas diferenças em relação ao português europeu. Mas todas se referem à vertente popular do português falado no Brasil, a língua falada pelo segmento majoritário da população brasileira. Alguns usam a denominação "português popular brasileiro" ou "português popular do Brasil", "norma popular", outros, "português não padrão", "português subpadrão" ou "português sub-standard”. Essa variedade sempre conviveu com a variedade dos contextos oficiais, a das elites educadas na Europa. E, certamente, a comunidade que a utilizava era reduzida - até a reforma do ensino promovida por Pombal, mesmo em Portugal era grande o número de analfabetos. Não foi a norma padrão escrita que veio para o Brasil, mas as variedades populares, faladas, que foram mantidas por uma po- 
pulação com pouca escolarização. O Brasil colonial teve poucas escolas, poucos letrados, poucos livros, nenhuma imprensa - a metrópole não incentivava a aquisição de conhecimento, pois uma população mantida na ignorância seria mais fácil de ser dominada. Mesmo com a vinda de D. João VI, em 1808, com a abertura dos portos e com a criação da Impressão Régia e do primeiro jornal brasileiro, a desigualdade impera. Fausto (1994, p.237) chega a falar, quando trata do final do século XIX, em um abismo separando a elite da grande massa de analfabetos e pessoas com pouca instrução formal. Mesmo com a República, com a urbanização e o início da industrialização do país, com a reformulação e a universalização do ensino, com a criação das primeiras faculdades, esse abismo perdura. Pelo menos duas variedades do português brasileiro são faladas: as chamadas norma culta e norma popular. Como a heterogeneidade é inerente às línguas, alguns pesquisadores apontam para o problema de se falar em "português brasileiro". Oliveira (2001, p.417), por exemplo, considera que é uma perspectiva generalizante e homogeneizante falar em um "português brasileiro" em oposição a um "português europeu"; operando com um conceito homogêneo de "português brasileiro", estaríamos "muito mais no âmbito da construção discursiva de uma 'língua nacional"”.

Assim, salienta-se, como o fazem Ilari e Basso (2006, p.151), que "a uniformidade do português brasileiro é em grande parte um mito". Essa ideia foi formada ao longo do tempo para garantir que o Brasil seria uma nação de dimensões continentais em que se falaria uma única língua; mas também se relaciona com uma falta de percepção da variação, não apenas a do outro, mas a própria, quando se promove uma adaptação aos contextos de uso. O mito foi também construído com o auxílio das gramáticas e dos dicionários, que tradicionalmente registram apenas a língua-padrão escrita. Além disso, como observa Tarallo (1993b, p.70), "o perfil da nossa gramática brasileira tem sido ditado 
pela tradição portuguesa e só esse fato torna o vácuo entre língua oral e escrita muito mais profundo no Brasil”.

A variação linguística é fenômeno frequente em toda comunidade de fala. Há, nas línguas, a possibilidade de uso de variantes, ou seja, de diferentes formas para expressar um mesmo significado referencial. Um fenômeno linguístico é variável quando há pelos menos duas formas alternativas para se dizer a mesma coisa com valor semântico equiparável. Por exemplo, o plural do sintagma nominal, composto de um núcleo substantivo obrigatório, modificado por um determinante e um adjetivo opcionais, é variável em português; a norma-padrão exige a concordância redundante, ou seja, a marcação do plural nos três constituintes, como em "os livros antigos", mas, muitas vezes, a marca de plural incide apenas sobre o determinante, como em "os livro antigo" ou sobre o determinante e o substantivo, como em "os livros antigo". O uso de uma ou outra variante não é, entretanto, aleatório; é influenciado por variáveis que podem ser linguísticas (condicionamento das variantes por fatores internos à língua, como fonologia, sintaxe, semântica) ou sociais (condicionamento por fatores externos à língua, como escolaridade, classe social). Os estudos sociolinguísticos desenvolvidos no século passado evidenciaram que não há variação livre, ou seja, há sempre condicionamento determinando a escolha de uma ou de outra variante.

As variantes podem conviver por curtos ou longos períodos de tempo, mas uma mudança só se completa quando uma das formas deixa de ser usada. Do ponto de vista linguístico, todas as variantes são legítimas, mas, do ponto de vista social, há avaliação. Em geral, a sociedade avalia positivamente a variante padrão, que passa a ser considerada de prestígio, enquanto as variantes não padrão, as que não estão descritas nas gramáticas, são socialmente estigmatizadas.

Há diferentes manifestações da variação: a diacrônica, relacionada ao tempo; a diatópica, dependente da região geográfica; 
a diastrática, relativa a estratos sociais; e a diamésica, referente ao meio em que se utiliza a língua.

A variação diacrônica é a que ocorre no decorrer do tempo e pode afetar todos os níveis: ortográfico, lexical, morfológico, sintático, semântico e pragmático. Os falantes mais idosos de uma língua percebem prontamente a lexical, quando as gerações mais jovens não mais entendem expressões que lhes pareciam corriqueiras. Mas há casos de variação diacrônica que não são tão facilmente percebidos, como "você", palavra que tem como origem a expressão de tratamento "Vossa Mercê", que se transformou em "Vosmecê" e que hoje é um pronome pessoal usado no Brasil em lugar do pronome de segunda pessoa "tu”, em várias regiões.

Mas essa já é outra manifestação da variação: a diatópica. No Brasil, temos diferenças lexicais, morfossintáticas e fonológicas associadas a regiões geográficas distintas. Ilari e Basso (2006, p.167-169) descrevem vários traços que diferenciam a pronúncia de falantes de diferentes regiões, como as diferentes realizações do "r", do "t" e do "d", assim como fatos de caráter morfossintáticos, como o uso ou omissão de artigos definidos antes de nomes próprios, o uso de "tu" ou "você" para expressar a segunda pessoa, e a tendência à omissão do pronome reflexivo com verbos pronominais (como em "eu penteei" em lugar de "eu me penteei”).

O estudo sistemático da variação diatópica no Brasil está sendo realizado por uma grande equipe de pesquisadores vinculados ao Projeto Atlas Linguístico do Brasil (ALiB), que se encontra na fase final de levantamento de dados e contava, em 2012, com a pesquisa finalizada em vinte estados. De acordo com Cardoso e Mota (2012, p.859), um dos objetivos do projeto ALiB é oferecer, a pesquisadores e pedagogos, subsídios para o aprimoramento do ensino do português e para uma melhor interpretação do caráter multidialetal do país. Outro objetivo é 
fornecer dados que permitam a autores de livros didáticos a adequação de seus trabalhos à realidade de cada região, e a professores uma reflexão sobre a variação que lhes permita encontrar meios de levar os estudantes ao domínio de uma variante tida como culta, sem desprestigiar sua variante de origem.

Alguns estados já foram mapeados e seus atlas regionais, publicados: Bahia (1963), Minas Gerais (1977), Paraíba (1984), Sergipe I (1987), Paraná (1990), Região Sul (2002), Pará (2004), Sergipe II (2005), Mato Grosso do Sul (2007), Ceará (2010). Esses atlas mostram que não há limites políticos para o uso de determinadas variantes linguísticas; por exemplo, em Minas Gerais identificaram-se três falares, um "baiano", um "paulista" e um "mineiro" (Zágari, 1998, 2005). As linhas virtuais que diferenciam o uso de uma ou outra variedade são denominadas isoglossas e elas são traçadas combinando-se feixes de traços morfológicos, fonológicos e lexicais, evidenciando uma relativa homogeneidade de uma comunidade linguística em relação a outras.

$O$ perfil dos informantes do projeto ALiB procura atender a questões espaciais; outras pesquisas concentram seu mapeamento em grupos socioeconômicos, ou seja, trata-se da variação diastrática. A maior parte dos estudos trabalham com dados relacionados tanto à renda familiar quanto à escolaridade, e incluem informantes do sexo masculino e feminino de diferentes faixas etárias. Tendo em vista que os fatos fonológicos e os morfofonológicos são mais facilmente sistematizáveis, os estudos desse tipo de dado têm sido os mais desenvolvidos no Brasil.

Quando se trata de escolaridade, no Brasil, verifica-se que o abismo mencionado acima em relação ao século XIX não foi superado. Os dados do Mapa do analfabetismo no Brasil (Brasil, s.d.), publicado pelo Instituto Nacional de Estudos e Pesquisas Educacionais (Inep), são aterradores. Se a taxa de analfabetismo saiu do patamar de 65,3\% em 1900 para chegar a 13,6\% em 2000, os números absolutos subiram de cerca de 6 milhões para 16 
milhões, considerando-se a população de 15 anos ou mais. Se levarmos em conta que o analfabeto funcional é aquele que não concluiu as quatro primeiras séries do ensino fundamental, esse número passou a 30 milhões, em 2000. Nesse mesmo ano, cerca de 350 mil pessoas concluíram o terceiro grau, de acordo com o Censo da Educação Superior (Brasil, 2009a). Ainda que esse número tenha mais que dobrado, chegando a cerca de $750 \mathrm{mil} \mathrm{em}$ 2007, a desigualdade é evidente, especialmente se considerarmos que, de acordo com o Censo Escolar de 2012 (Brasil, 2013), mais de 56 milhões de pessoas com mais de 18 anos não frequentavam a escola e não tinham o ensino fundamental completo.

Essa disparidade em termos educacionais se reflete na linguagem, pois se constata uma grande diferença entre a chamada norma culta, falada pela população de maior escolaridade e renda mais alta, e o português popular brasileiro, falado pela faixa menos escolarizada e com renda mais baixa. Os dois segmentos têm sido estudados pela sociolinguística, abordando tanto a modalidade escrita quanto a falada.

E a variação relacionada aos diferentes meios, o escrito e o falado, é denominada variação diamésica. Como a escrita é planejada e pode ser corrigida antes de ser tornada pública, tende a estar mais próxima da norma-padrão ou língua-padrão, em situações formais. Faraco (2002, p.40) traça a distinção entre norma culta, entendida como a norma linguística praticada em determinadas situações por grupos sociais relacionados com a cultura escrita, e norma-padrão. Como a cultura escrita, associada aos grupos que controlam o poder social e por eles historicamente legitimada, tende à unificação e à estabilização linguística, à neutralização da variação e ao controle da mudança, o resultado é uma norma estabilizada, a norma-padrão ou língua-padrão. Bagno (2003) estabelece distinção similar, mas o modelo idealizado de língua é nomeado por ele como "norma-padrão"; "norma", no caso, refere-se à prescrição, à regra a ser seguida. Para evitar a relação de 
antonímia entre norma culta e norma inculta ou popular, o autor prefere o termo "norma de prestígio", salientando que o prestígio é social, e emprega a expressão "variedade estigmatizada".

A língua-padrão é a língua fixada pelas gramáticas e resulta em

uma atitude purista e normativista que vê erros em toda parte e condena qualquer uso - mesmo aqueles amplamente correntes na norma culta e em textos de nossos autores mais importantes - de qualquer fenômeno que fuja ao estipulado pelos compêndios gramaticais mais conservadores. (Faraco, 2002, p.43)

A norma prescritiva não é a língua, mas uma de suas descrições; diferentemente das feitas por linguistas, é a descrição associada a juízos de valor, à boa linguagem, ao falar ou escrever supostamente corretos. Mas, como se trata da norma que é ensinada na escola, acaba por funcionar como parâmetro para a realização culta da língua e, como consequência, funciona como fator de discriminação e exclusão sociocultural, via preconceito linguístico.

Estudos realizados no âmbito do Projeto Gramática do Português Falado, iniciado no final dos anos 1980, assim como pesquisas desenvolvidas por sociolinguistas, no entanto, indicam que a norma culta falada não é a norma-padrão. Scherre (2005, p.19-20) fornece vários exemplos de que, na modalidade falada, "mesmo pessoas escolarizadas deixam de colocar todas as formas de plural em construções diversas".

Ainda que, na escrita, haja maior monitoramento que na fala, vários autores (Faraco, 2002; Scherre, 2005; Bagno, 2003) fornecem exemplos de fenômenos frequentes na fala culta que se manifestam também na escrita, em contextos em que não se esperaria sua presença, como nos jornais Folha de S.Paulo, Jornal do Brasil, Correio Braziliense, O Estado de S. Paulo. Apesar disso, lemos, na Folha de S.Paulo, em uma coluna editorial 
assinada por Roberto Dias (2013, p.A2), secretário-assistente de redação, que "quem sintoniza o rádio hoje no Brasil pode achar que os plurais foram abolidos da língua portuguesa" e que "parece ter sido implantada uma novíssima gramática, que desconhece fronteiras de gênero musical e regras de conjugação verbal". Seus exemplos incluem "as minas pira", "liga nóis canta assim", "traz bebida pras gatona, deixa elas malucona”, “o novinha, vem com nóis, nóis damo condição”. Conservador, lamenta ter ficado longe a época em que a música "produzia exemplos escolares".

Dias equipara a língua ao padrão das gramáticas e deixa implícito que apenas esse padrão deve entrar na escola e ser ouvido no rádio. Parece ignorar o fato de que a língua é uma atividade social relacionada a identidades e que os autores das letras mencionadas apenas dão voz às formas constitutivas de sua formação, do grupo social a que pertencem, ao qual aderem e por ele são consagrados. O paulista Adoniran Barbosa, filho de imigrantes italianos, desde os anos 1950, introduzia em suas letras sua marca identitária, usando formas bastante semelhantes às execradas por Dias; no famoso "Samba do Arnesto", por exemplo, ${ }^{5}$ encontramos formas como "nóis fumo mas não encontremo ninguém" e "da outra veiz nóis num vai mais".

O jornalista não se limita a praticar o preconceito linguístico dizendo que as músicas promovem "atentado à sintaxe", aniquilam "a conjugação do verbo"; ele também traça uma relação entre a maneira (pobre?) como os autores escrevem e seus dotes cognitivos, ao lembrar que "o filósofo Wilhelm von Humboldt dizia que a linguagem espelha o pensamento”. Uma relação ilegítima entre construções linguísticas e as pessoas que as empregam é naturalizada, desqualificando uma parcela majoritária da

5 Disponível em: <http://www.vagalume.com.br/adoniran-barbosa/samba-do-arnesto.html>. Acesso em: dez. 2013. 
população brasileira que tem acesso restrito à educação formal de qualidade, ou seja, à cultura letrada. Valoriza-se o que vem de uma minoria dominante que apenas conserva a estrutura de exclusão implantada no Brasil colônia e preserva o abismo acima mencionado entre letrados e não letrados. Materializa-se, com o exemplo de preconceito linguístico, o que Gnerre (1985) denunciava: uma variedade "vale" o que "valem", na sociedade, os seus falantes, ou seja, uma variedade linguística é avaliada em relação ao tipo de poder e autoridade que seus falantes mantêm nas relações econômicas e sociais.

O preconceito, social, religioso, racial, relaciona-se estreitamente à não aceitação da diferença. Ainda que a sociedade brasileira esteja se abrindo para a alteridade, o preconceito linguístico está nela fortemente arraigado, fruto do conservadorismo e da intolerância em relação à variação e à mudança. Um dos desafios da contemporaneidade é o reconhecimento e a aceitação, não apenas da heterogeneidade do português, mas também de muitas outras línguas que foram e são faladas no Brasil.

Oliveira (2000) estima que as comunidades de imigrantes e de seus descendentes falem cerca de trinta línguas. Hoje elas podem ser utilizadas até na imprensa, mas nem sempre foi assim. Do mesmo modo como Pombal reprimiu o ensino em línguas gerais e indígenas, a política nacionalista do Estado Novo instaurado por Getúlio Vargas gerou a proibição do uso de línguas estrangeiras em escolas e em instituições fundadas por grupos de imigrantes, especialmente os alemães, os italianos e os japoneses. Interditou-se a fala de língua estrangeira no Brasil em nome de uma suposta unificação nacional, com o intuito de forjar uma identidade homogênea para a população do Brasil. E o multilinguismo foi, mais uma vez, reprimido.

Além das línguas trazidas pela imigração, temos as chamadas línguas autóctones, as línguas indígenas. Rodrigues (2006, p.153) calcula que, na contemporaneidade, as nações indígenas 
do país falem cerca de 189 línguas. ${ }^{6}$ Muitas delas são faladas por populações reduzidíssimas e é pouco provável que sobrevivam. O fato é lamentável, mas não surpreende, pois foi apenas com a Constituição de 1988 que se assegurou aos povos indígenas o direito às suas línguas no sistema escolar. Entretanto, de acordo com relatório do Inep (Brasil, 2009), apenas em 1999 a categoria "escola indígena" foi regulamentada, com o intuito de garantir a especificidade do modelo de educação intercultural e bilíngue. A escola, que foi um dos principais instrumentos de negação da diversidade linguística e de imposição do português como língua nacional, pode passar a ter um papel importante na manutenção da diversidade linguística no Brasil. Dois relatórios sobre a educação indígena, um baseado no Censo Escolar de 2005 (Brasil, 2007), outro no Censo Escolar de 2008 (Brasil, 2009), evidenciam que há longo caminho a percorrer, antes de se comemorar a criação das escolas indígenas. Os dados levantados mostram que, de 2.698 escolas, atendendo a cerca de 200 mil alunos, 1.783 têm o ensino bilíngue e 128 ministram as aulas somente em língua indígena. Nas demais, 787, o ensino é ministrado apenas em português, tanto em comunidades que perderam suas línguas e hoje o português é sua língua, quanto em comunidades que falam sua língua no cotidiano, mas não nas atividades escolares. A quase totalidade das matrículas é no ensino fundamental e infantil, pois não atinge $6 \%$ a taxa de matrículas no ensino médio. Isso significa que, se o aluno quiser dar continuidade a seus estudos, terá que se deslocar de seu ambiente.

Os maiores problemas enfrentados parecem estar em relação ao material didático e à formação dos professores. Apenas 38,4\% (1.035) das escolas contam com material didático especialmente elaborado para alunos indígenas. Um dos desafios do ensino

6 Rodrigues (1994, p.18) calculava que fossem por volta de 170 as línguas indígenas faladas no Brasil. 
bilíngue ou em língua indígena é o desenvolvimento de material específico para esse fim, especialmente ao se considerar que algumas línguas não foram suficientemente descritas ou não possuem escrita. Quanto aos professores, dos cerca de 11 mil que atuam nas escolas, apenas $40 \%$ são licenciados e $38 \%$ cursaram apenas o ensino fundamental, nem sempre completo. Assim, a preparação de material didático e a formação de professores são prioritárias.

O maior desafio, entretanto, é social. O hiato de 11 anos entre assegurar às nações indígenas, na Constituição, o direito às suas línguas e a regulamentação da educação indígena indica que a sociedade não está preocupada com a questão e que a morte de línguas não é problema. A ideia de que são línguas menores, desarticuladas, parece estar arraigada no imaginário do brasileiro, pleno de enunciados preconceituosos para com a diferença.

A mesma sociedade que apagou de sua memória as outras línguas faladas no Brasil, que encara com preconceito as variedades menos prestigiadas do português, parece não querer ser lembrada de que há heterogeneidade interna. Pelo menos em relação à língua, no imaginário das elites, a diferença pressupõe inferioridade.

O episódio bíblico da torre de Babel relata que a tribo dos Shem decidiu, totalitariamente, erguer uma torre para chegar aos céus e impor sua língua e sua razão a todos os povos. Deus, entretanto, interrompeu a construção e instituiu a diversidade de línguas. Assim, ao mesmo tempo em que deu o presente da heterogeneidade, barrou a possibilidade do imperialismo linguístico: os Shem não podiam mais impor sua língua, nem o seu sentido como o único. A monstruosa homogeneidade linguística, acompanhada da negação ou do desconhecimento do outro, foi barrada. Para Niranjana (1992, p.144), entretanto, a intervenção "iniciou a violência cultural", pois se uma língua não é imposta, os sentidos são determinados pelo mais poderoso, os valores são atribuídos pelos dominadores. 


\title{
A passeata contra a guitarra e a "autêntica" música brasileira
}

\author{
Valéria Guimarães ${ }^{1}$
}

\section{"Abaixo à guitarra!"}

Havia uma rivalidade muito estimulada pela TV Record também, que tinha um monopólio dos musicais da época, televisão não tinha novela, o forte da televisão era o musical e a Record tinha sob contrato $90 \%$ da música brasileira. Todo dia tinha um programa musical e a Record tinha interesse que os programas de televisão fossem para os jornais, para as rádios, para a vida das pessoas, então era engraçado porque na época se dizia que a MPB era a música brasileira e a Jovem Guarda era a música jovem. E a gente pensava: Meu Deus do céu, por que não pode

1 Professora no Departamento de História da Universidade Estadual Paulista "Júlio de Mesquita Filho" (Unesp), câmpus de Franca. É autora de Notícias diversas: suicídios por amor, leituras contagiosas e cultura popular em São Paulo dos anos dez (2013) e é pesquisadora responsável pelo Projeto Jovem Pesquisador/Fapesp As transferências culturais na imprensa na passagem do século XIX e XX - Brasil e França. E-mail: valeria.s.guimaraes@uol.com.br. Agradeço às contribuições de Marcelo Januário nas discussões e na seleção das músicas aqui analisadas e também a José Adriano Fenerick pela leitura da primeira versão do texto e às suas esclarecedoras observações. 
haver uma música jovem e brasileira ao mesmo tempo? Uma pergunta óbvia mas que era pertinente nesse tempo a ponto das pessoas organizarem uma passeata em plena ditadura militar, com tanta coisa para protestar! Organizar uma passeata com 300, 400 pessoas, com faixa, cartaz e as pessoas gritando: "Abaixo à guitarra! Abaixo à guitarra!” A guitarra elétrica como símbolo do imperialismo ianque, aqueles clichês do velho comunismo que estavam muito ativos na época. Nelson Motta, Uma noite em 67 (2010)

Essa epígrafe foi retirada do documentário Uma noite em 67, que fala sobre um fenômeno da indústria brasileira do entretenimento nessa época, os festivais musicais patrocinados pela rede de televisão Record. Além do conhecido jornalista Nelson Motta, vários outros se pronunciam sobre o episódio curioso da nossa história cultural, a "passeata contra a guitarra elétrica", ocorrida em 17 de julho de 1967, partindo do Largo de São Francisco para o antigo Teatro Paramount, o "Templo da Bossa". $\mathrm{Na}$ primeira fila da manifestação, cuja imagem foi reproduzida neste documentário, era possível ver Elis Regina, Gilberto Gil ao centro, acompanhado de Jair Rodrigues e Edu Lobo.

Posteriormente ridicularizada por alguns dos presentes, comparada por Nara Leão - que se recusou a integrá-la, embora tenha sido convidada - a um ato fascista, rejeitada por participantes aparentemente arrependidos, como Gilberto Gil, talvez hoje em dia ainda atraísse adeptos.

Sérgio Cabral, jurado dos festivais, fez uma autocrítica bem explícita:

Olha, eu hoje faço minha autocrítica. Eu fiquei ao lado da passeata, né, que hoje eu vejo até como uma coisa ridícula. Claro, pouco depois eu vi, eu me tornei produtor de disco e vi, enfim, 
uma bobagem ficar contra a guitarra elétrica! É uma coisa idiota, né?! Uma bobagem. Mas, a gente, [para] nós nacionalistas, nós da esquerda, a música não podia ser invadida pelo que vinha de fora e a guitarra elétrica era um símbolo desta invasão. Cabral, Uma noite em 67 (2010)

A situação estava polarizada em dois grupos: o Fino da Bossa e o Jovem Guarda, programas da TV Record. No primeiro, nomes presentes nesta passeata contra a guitarra eram frequentes, como Elis Regina, Jair Rodrigues, Geraldo Vandré, Edu Lobo e outros. No segundo, as figuras mais emblemáticas eram Roberto Carlos, Erasmo Carlos e Wanderléa que, embora tocassem músicas bem comerciais, adotaram a guitarra e mesmo a postura rocker sem grandes conflitos.

Mesmo atualmente não é raro que, no Brasil, o rock - estilo em que o som da guitarra é um elemento central - seja associado à imaturidade, música pouco sofisticada ou, de alguma forma, seja visto como um sintoma de cópia das referências estrangeiras e, nessa lógica, seja entendido como um sinal de pouca adesão à música "verdadeiramente" brasileira. Além disso, ainda permanece o estigma que persegue seus músicos devido à imagem de rebeldes, alimentada por muitos deles, ainda que sua postura seja bastante profissional.

Mas o que é essa música brasileira? Talvez seja a bossa-nova? Bem vendida no exterior e, de alguma maneira, embaixadora da "cultura brasileira", a bossa-nova traduzia uma identidade ligada à sofisticação, exotismo, originalidade e, sobretudo, diferença frente à hegemônica música "americana” em que quase sempre se fazem sentir os acordes da guitarra. Mas o que faz um tipo de música ser entendida como autêntica, típica de um país? Não podemos dizer que todo o tipo de música feita no Brasil contém um elemento estrangeiro? Neste caso, por que combater um instrumento musical e a música que ele representa como "símbolo do imperialismo"? 
Talvez não cheguemos a conclusões, mas nosso objetivo neste ensaio é apenas especular sobre o tema da identidade nacional brasileira no período contemporâneo, tendo em vista a cultura midiática e seus produtos cada vez mais universais, ${ }^{2}$ tomando como ponto de partida algumas das manifestações culturais como a música. A passeata contra a guitarra ocorre nesse momento que vai dos anos 1950 até fins da década de 1970, período de transição entre o desenvolvimento da indústria cultural e a inserção do Brasil na era da globalização. Tomamos o termo globalização, aqui, no sentido que lhe atribui Ulrich Beck (1999), como um processo que se inicia em fins do século XX e que caracteriza o fim da ideia de nação, como a tínhamos na modernidade, como unidade fechada e territorialmente delimitada, além de marcar um redimensionamento em várias esferas da sociedade, com destaque para as mudanças tecnológicas. Embora seu ponto de inflexão seja os anos 1980, com a ascensão de Thatcher e Reagan, em termos culturais o processo já havia se iniciado.

Podemos ainda utilizar o conceito de "cultura midiática" (Maigret, 2010) para nos referirmos à mundialização da produção cultural voltada ao grande público que, se tem seu início já no século XIX, encontra sua expressão mais acabada a partir de meados do século XX, ancorada sobretudo na crescente velocidade dos meios de comunicação e nas novas possibilidades de integração internacional.

As trocas culturais não se dão apenas com um sentido de dominação imperialista, outros fatores estão em jogo na complexa circulação dos artefatos culturais. A música, pelo fato de ser uma das expressões de maior peso da cultura midiática de nossos tempos, é um excelente objeto de pesquisa para observarmos esse fenômeno da interação dos produtos culturais na indústria cultural.

2 Incluindo a imprensa, tema sobre o qual já temos nos dedicado há algum tempo. Guimarães (2012). 
Além disso, a música também era considerada por Mário de Andrade ${ }^{3}$ como a mais completa expressão da brasilidade, de forma que achamos bastante pertinente associar o fenômeno cultural da música brasileira com a questão da identidade nacional a fim de problematizar a própria ideia de identidade.

Assim, a passeata contra a guitarra é um dos episódios mais curiosos justamente porque ele, em si, nos causa desconforto e estranheza hoje em dia.

Quem, atualmente, iria aderir a uma passeata dessas?

Nelson Motta afirma claramente no trecho em epígrafe que a questão, embora tenha se delineado em termos ideológicos, apresentava um componente mercantil bem concreto: o estímulo à rivalidade entre os dois grupos tinha origem em uma briga por nichos de mercado. Mas seria apenas isso? Ele mesmo cita a retomada dos "clichês comunistas" no discurso contra a crescente aderência à guitarra, deixando claro o viés engajado desta atitude, muito em consonância com o clima de manifestações, cujo tom era abertamente nacionalista, contra o recrudescimento do autoritarismo. ${ }^{4}$

Mesmo aqueles que defendem a existência de uma música popular genuinamente brasileira - seja lá o que for isso e se for possível definir algo como tal - não se arriscariam a protestar contra um instrumento que, há muito, fora absorvido pelas bandas locais sejam elas de rock ou não.

3 É Mário que diz no seu Ensaio sobre música brasileira (1928): “a música popular brasileira é a mais completa, mais totalmente nacional, mais forte criação de nossa raça até agora" (Andrade apud Napolitano, Wasserman, 2000, p.169).

4 Como expõe Arnaldo Daraya Contier (1998), é possível estabelecer uma relação entre a chamada "música de protesto" feita por músicos como o Edu Lobo e o discurso nacionalista perpetrado pelo Centro Popular de Cultura (CPC), que reunia intelectuais e artistas de esquerda em prol de uma arte popular revolucionária. Ele também observa na nota 3, com Marcos Napolitano, esta ambiguidade do sentido da passeata, ao mesmo tempo ideológico e mercantil. 
Temos, então, um fenômeno ambíguo, que reúne ideologia, mas que talvez não mostrasse a mesma força e repercussão se não tivesse o apoio da mídia. Dessa forma, para tentarmos compreender ou, ao menos, vislumbrar algumas hipóteses para explicar como a questão da identidade nacional aflora nesta recusa à guitarra - como instrumento que representa o "imperialismo ianque" - temos que nos deter em duas frentes: uma delas para explicar a recorrência da questão do "nacional-popular" na nossa historiografia, o que certamente teve eco na abordagem dos grupos contra a guitarra; outra, entender sua articulação com a consolidação de uma cultura midiática no Brasil neste contexto bem específico de globalização (em termos mundiais) e de ditadura política (em termos nacionais).

\section{Popular, popularesco: identidade e música popular}

A ideia de autêntico e puro pode ser caracterizada como uma concepção romântica, que reúne o hábito colecionista dos antiquários e a idealização do passado (Ortiz, 1992, p.17-22). Todos os vestígios ganham importância exacerbada e mesmo o mais insignificante objeto torna-se alvo de culto. Sua importância está vinculada à sua pureza, causando uma busca irrefreada pelas origens que quanto mais remota for, mais é valorizada e passível de ser idealizada. Como bem demonstra Peter Burke em sua obra magistral Cultura popular na Idade Moderna (2010), os estudiosos da cultura popular "estavam preocupados com o estudo das origens, em detrimento do significado desses rituais" $e$ "Aceitavam com muita facilidade o mito de uma cultura popular imutável" (2010, p.123). O que legitima, por fim, determinados dispositivos como "verdadeiramente" originais é um jogo de forças de representações que elegem uma determinada memória social (Chartier, 2010; 1988). 
Os sentimentos nacionais têm sido erigidos sistematicamente dentro desta lógica, em que o conceito de "nação" só pode ser compreendido como uma expressão coletiva que aplaca as diferenças de classe, credo, raça, idade ou gênero para reunir o "povo" em uma mesma noção de pertencimento.

O filósofo romântico alemão Herder chega mesmo a distinguir como parte central destes "arquivos da nacionalidade" (Ortiz, 1992, p.26) a língua, o que nos parece bastante claro uma vez que a ideia de nação passa pelo compartilhamento de um território por determinada população cuja origem se supõe comum, mas também pelo compartilhamento de uma mesma língua, leis, regras entre outros.

E a língua, mais que outros componentes da concepção de nação, é central na construção da noção de identidade por traduzir “o caráter de um povo" (Ortiz, 1992, p.22). Dentre suas expressões mais importantes está a poesia ou canção popular, suposto registro da "origem" perdida (Burke, 2010, p.26), que seria uma "poesia de natureza" diferente da "poesia de cultura"; esta última não possui nem a espontaneidade, nem a intuição da primeira.

E, enquanto os versos "originais" e, então, "nacionais" seriam expressão de todo povo, a poesia culta seria apenas a expressão do indivíduo. Recitados de memória, os versos da poesia "original" deviam ser recuperados antes que o processo de modernização das cidades extinguisse seus guardiões. Esse gosto pelas sobrevivências arcaicas permanece na pretensamente científica abordagem do campo do Folclore que via os hábitos populares como expressão da tradição.

Tal concepção de cultura popular aparece na noção de música brasileira que prevaleceu na campanha contra a guitarra.

A exclusão de determinadas expressões culturais em detrimento de outras faz parte do jogo de poder que constrói a memória, e com a MPB não foi diferente. Os problemas epistemológicos decorrentes dessa falta de definição do que seria a 
música brasileira "original" já foram bem explorados em trabalhos de especialistas brasileiros.

Álvaro Neder (2010) observou como vários campos de força rivalizam no combate que visa a eleger a "verdadeira" ou "autêntica” música popular brasileira. A nosso ver, na noção de guitarra como agente imperialista prevalece a concepção de música do "povo", que pode ser compreendida com base nas categorias românticas acima expostas, a qual contempla a noção de música regional e/ou rural, distante da "civilização" urbana e, portanto, pouco "corrompida" e mais "autêntica". Ela se consolidaria como resistência à modernização.

Neder atribui o estigma que sofre a música "popularesca" brasileira, expressão de Mário de Andrade para designar a música voltada para o mercado, à interpretação predominante - e equivocada, segundo ele - da crítica perpetrada por este autor modernista.

Apesar dessas e de outras evidências, no entanto, nem sempre a dialética do pensamento andradiano foi considerada por seus seguidores, resultando em uma visão da "música popularesca", no mínimo, pouco favorável.

Esta parece ser, talvez, uma das importantes razões para o desprestígio da música popular (tal como a entendemos hoje, com todas as suas contradições - não apenas a música "sofisticada" como a de um Tom Jobim, mas também a música "brega" como a de um Lindomar Castilho, além de muitas outras) no espaço institucional acadêmico brasileiro da música. Esta preocupação é explicitada pelo musicólogo Sean Stroud, indicando, no estranhamento de seu olhar estrangeiro, a visível contradição entre a sociedade e a academia neste país. (Neder, 2010, p.184)

Embora tenhamos visto que o grupo de artistas contra a guitarra também estivesse inserido no mercado da indústria cultu- 
ral, inclusive brigando pela audiência em uma emissora de TV, eles reivindicavam para si essa concepção de MPB que a identifica com pureza, com a "canção natural" em detrimento de tudo o que consideram estrangeiro ou, simplesmente, "popularesco”, para usar a expressão de Mário de Andrade.

Napolitano e Wasserman (2000, p.168) dividem em duas as correntes historiográficas dedicadas a pensar a questão da "origem” da música popular brasileira: uma que busca a autenticidade e outra que questiona a própria noção de origem (em que os autores se inserem).

Para analisar como a questão das origens - entendida como momento fundador que delimitaria um núcleo identitário perene é pensada na música popular brasileira, podemos nos concentrar basicamente em duas grandes correntes historiográficas: a primeira diz respeito à discussão quanto à "busca das origens", ou seja, a raiz da "autêntica" música popular brasileira. A segunda corrente historiográfica procura criticar a própria questão da origem, sublinhando os diversos vetores formativos da musicalidade brasileira, sem necessariamente, buscar o mais autêntico. (Napolitano; Wasserman, 2000, p.168)

A rigor, se desde o século XVIII já se delimitam as feições do que se chamou música brasileira (lundus, modinhas), não é possível deixar claro sua especificidade. Seja através de uma análise acadêmica, seja técnico-musical, a definição do que é "música popular" é de tal modo polissêmica que definir o que é "Música popular brasileira" torna-se tarefa impossível, pois o que a torna particular é a fusão de vários elementos, sendo complexo precisá-los. Durante o século XX o maxixe e o samba ganham espaço no ambiente da cidade, enquanto as danças "folclóricas" ou dramáticas (Napolitano; Wasserman, 2000, p.168) expressam a música brasileira rural, compondo esse quadro musical que se identifica como brasileiro. 
A mercantilização dos artefatos musicais, no entanto, já caminha a passos largos, e em 1950 podemos perceber um processo intenso de internacionalização do mercado musical brasileiro. Ao lado de marchinhas de Carnaval, os boleros mexicanos, tangos argentinos e o jazz americano ganham espaço no rádio, fazendo com que haja um movimento de reflexão sobre a preservação da música popular brasileira.

É neste momento que o samba toma o centro do debate tornando-se símbolo de uma identidade genuinamente brasileira (Napolitano; Wasserman, 2000, p.174). A Revista de música popular (1954-1956) tomou para si a tarefa de refletir e exaltar o samba como expressão da brasilidade. E mesmo a bossa-nova, cuja identidade hoje em dia é tão ligada ao samba, foi vista como ameaça modernizante ao samba de raiz. José Ramos Tinhorão parece ter sido um de seus principais críticos, sobretudo pela oposição aos elementos internacionalizantes que as novas tendências traziam para a música popular brasileira, vistas por ele como investidas da dominação cultural (Napolitano; Wasserman, 2000, p.79). Dessa forma, Noel Rosa ou Tom Jobim seriam tão algozes da música brasileira quanto o mercado fonográfico cada vez mais dominado pelas gravadoras multinacionais.

Trabalhos mais recentes têm tentando mostrar o quanto esse sucesso do samba tem menos a ver com uma espoliação branca de uma expressão original popular-negra que uma "invenção de uma tradição", no sentido que dá Hobsbawm (Hobsbawm; Ranger, 1984). Aproveita-se um gênero musical já bem difundido entre várias camadas sociais para forjá-lo como símbolo nacional, como a "verdadeira" música brasileira. Como esclarece Hermano Vianna:

Como todo processo de construção nacional, a invenção da brasilidade passa a definir como puro ou autêntico aquilo que foi produto de uma longa negociação. O autêntico é sempre artificial, mas, 
para ter "eficácia simbólica", precisa ser encarado como natural, aquilo que "sempre foi assim". O samba de morro, recém-inventado, passa a ser considerado o ritmo mais puro, não contaminado por influências alienígenas, e que precisa ser preservado (afastando qualquer possibilidade de mudança mais evidente) com o intuito também de se preservar a "alma brasileira". (Vianna, 1995, p.152-153)

Cabe acrescentar, ainda, uma última reflexão sobre o conceito de música popular de maneira geral, universo do qual a MPB não é senão uma parte. Vimos como concepções distintas cabem na designação de "música popular": expressão primitiva em oposição à música erudita ou folclórica; voltada para a maioria em oposição à música de elite (Birrer, 1983, p.104 apud Neder, p.185) ou música simples, fácil, acessível em oposição à sofisticação da música erudita. E quase sempre definida como pares de opostos: rural/urbana, morro/asfalto, periferia/centro, pureza/ mestiçagem, nacional/estrangeira, popular/classe média, popular/erudito, artesanal/comercial entre outros. Na melhor das hipóteses, seu componente "primitivo" seria higienizado pela "boa" música popular - aquela que, trabalhada de forma erudita anularia os resquícios do naïf.

Por oposição, a música popular seria entendida como "acessível", "simples", "fácil". No entanto, muitas peças comumente compreendidas como eruditas (o coro "Aleluia" de Handel, muitas canções de Schubert, muitas árias de Verdi) possuem qualidades de simplicidade. Da mesma maneira, não parece que as gravações dos Sex Pistols sejam "acessíveis", que a obra de Frank Zappa seja "simples” ou que a de Billie Holiday seja "fácil”. (Neder, 2010, p.185)

Há ainda quem defenda a tese, como o faz José Ramos Tinhorão, da dicotomia entre música folclórica e música popular, 
sendo a primeira uma expressão coletiva, anônima e tradicional enquanto a segunda seria de assumida autoria, gozando de espaço nos aparatos de difusão, mediada pela tecnologia e caracterizando-se, assim, como produto de uma indústria cultural, o que tiraria sua legitimidade como representante de uma identidade nacional. ${ }^{5}$

A concepção de "cultura popular" articulada à noção de identidade - nacional-popular -, que domina a esfera da reflexão sobre a música brasileira, se fez sentir de maneira clara neste episódio cuja protagonista era a guitarra.

E mesmo autores que se propõem a questionar esse simplismo no tratamento de fatores complexos das articulações nacional/estrangeiro, ainda procuram o "original”, concentrando-se na questão da recepção, uma "apropriação ativa, transformação e incorporação por parte das classes populares de algo que passa a lhe pertencer de fato e direito - a exemplo da harmonia no samba, no cururu, na moda de viola e em muitas outras músicas tradicionais" (Neder, 2010, p.186). Ou seja, mesmo que a ênfase seja no diálogo e na negociação e não na influência de fatores externos, ditos imperialistas, que combateriam a originalidade da música nacional, ainda se concebe em termos teóricos uma troca cultural que adquire um sentido unilateral - sempre vem de fora para ser reapropriada. As "classes populares" estão sempre no papel de receptoras e recriadoras, mas não de criadoras, pois o contato com o exterior de alguma forma a modificaria, em um jogo de aceitação e recusa.

5 A esse respeito, o comentário que segue é esclarecedor: "Sob essa ótica [a da oposição entre música folclórica e popular], há uma preocupação em separar o que é popular e o que é folclórico: a música folclórica seria aquela de autor desconhecido, transmitida oralmente de geração em geração; a música popular, ao contrário, seria a composta por autores conhecidos e divulgada por meios gráficos (ou seja, através da gravação e venda de discos, partituras, fitas, filmes etc.), cujo lugar social são as cidades industrializadas" (Napolitano; Wasserman, 2000, p.179). 
Mas, no caso da guitarra elétrica, o que vem de fora vem sempre dominar? Vem sempre corromper - ou modificar - o que se encontra em estado "puro"? Apropriação e incorporação sempre têm que se dar como resistência, na medida em que há uma modificação? Ou seria melhor falar em troca cultural ainda que esta não seja simétrica?

Não seria muito lembrar do ensaio "Nacional por subtração" de Roberto Schwarz, em que ele explica tão bem, com sua habitual prosa irônica, essa recusa às importações:

Quando os nacionalistas de direita em 64 denunciavam como alienígena o marxismo talvez imaginassem que o fascismo fosse invenção brasileira. Neste ponto, guardadas as diferenças, as duas vertentes nacionalistas coincidiam: esperavam achar o que buscavam através da eliminação do que não é nativo. O resíduo desta operação de subtrair, seria a substância autêntica do país. (Schwarz, 1997, p.33)

Nesta oportunidade o crítico observa como o tema do "caráter postiço, inautêntico, imitado da vida cultural que levamos" (Schwarz, 1997, p.29) é uma constante no pensamento não só brasileiro, como latino-americano. Inúmeras seriam as inadequações ${ }^{6}$ se o olhar sobre o estrangeiro for sempre direcionado pelo viés da cópia ou influência. Soariam, assim, como imitações descabidas e ameaçadoras à nossa identidade a importação da figura glacial do Papai Noel nos trópicos, por exemplo, ou a adoção da guitarra elétrica. Como ele mesmo diz: "Da ótica de um tradicionalista, a guitarra elétrica no país do samba é outro (exemplo de inadequação)" (Schwarz, 1997, p.29).

6 Em outro ensaio o tema é exposto de maneira mais contundente como "ideias fora do lugar". 
Pois bem, até Roberto Schwarz não deixou escapar esse momento esdrúxulo de nossa vida cultural, sobretudo quando vislumbramos um contexto de intensa globalização:

O que seria uma economia nacional sem mistura? De 64 para cá a internacionalização do capital, a mercantilização das relações sociais e a presença da mídia avançaram tanto que estas questões perderam em verossimilhança. Entretanto, há 20 anos apenas [ele escreve em fins dos anos 90] elas ainda agitavam a intelectualidade e ocupavam a ordem do dia. (Schwarz, 1997, p.32)

Embora, como bom lukcasiano, ele considere centrais os "mecanismos de dominação norte-americana", Roberto Schwarz não deixa de perceber como estes mesmos "mecanismos" serviam para uma "mitificação da comunidade brasileira, objeto de amor patriótico e subtraída à análise de classe que a tornaria problemática por sua vez" (Schwarz, 1997, p.32).

Em outro momento de grande lucidez, ele explicita um mecanismo geracional que expõe a força da recepção, destacando a presença da televisão como um importante acontecimento no panorama cultural brasileiro: se para os nacionalistas o imperialismo estava nos signos americanos presentes na televisão, por exemplo, para a geração nascida sob a nova configuração cultural "o nacionalismo é que teria de parecer esteticamente arcaico e provinciano. Pela primeira vez, que eu saiba, entra em circulação o sentimento de que a defesa das singularidades nacionais contra a uniformização imperialista é um tópico vazio" (Schwarz, 1997, p.33).

Não nos esquecemos que o autor critica a tendência oposta também, aquela que defende, com um ar libertador e otimista, um suposto "mundo universalista" calcado nas mídias de alcance universal. O sociólogo francês Éric Maigret (2010), de forma similar, inclui a tendência pessimista nas correntes "racionalis- 
tas marxistas" que se consideram herdeiras do Iluminismo, e igualmente questiona o otimismo dos defensores da existência de uma "aldeia global" livre e democrática.

Sendo assim, nosso desafio neste ensaio é, antes de tudo, abrir a discussão sobre os mecanismos de interação entre suas culturas frente à questão da identidade brasileira.

\section{Trocas culturais na indústria cultural}

No episódio da guitarra elétrica o que predomina é uma visão pessimista das trocas culturais com os países estrangeiros; sendo mais comum, como temos visto, à época e mesmo tempos depois, o achincalhe da introdução desse instrumento no cenário musical brasileiro. Assim, a resistência de alguns grupos à guitarra e, por consequência, ao rock de matriz anglo-saxã tinha esse sentido crítico e pessimista que via, em âmbito restrito, a importação de um instrumento estranho à nossa tradição nacional-popular como americanização e imperialismo, e, no âmbito geral, tinha um sentido de combate à expansão da indústria cultural e seus artefatos, considerados, assim, alienantes.

Parece-nos pertinente, então, afirmar que essa visão está presente no discurso desses grupos que elegeram a introdução da guitarra elétrica no panorama artístico nacional como sinal do imperialismo ianque, signo este que se torna, deste ponto de vista, símbolo da sociedade de mercado que mina a ideologia e favorece a manipulação da opinião pública, tornando-a expressão acabada de uma massa atomizada.

O mais irônico disso tudo é que esses mesmos críticos da indústria cultural no Brasil - com todas as consequências de uma cultura midiática em expansão, como a estandardização - eram também ligados ao entertainment. Eles estavam fazendo, talvez sem o saber, a crítica ao próprio meio de que provinham. 
Mas essa recepção não foi homogênea, como é possível concluir pelo depoimento de Nelson Motta, ou pela reação de Nara Leão e Caetano Veloso. Sem falar, é claro, dos roqueiros - os responsáveis pela introdução do instrumento e o alvo direto da famigerada marcha.

Para analisar a adesão à guitarra, portanto, temos que necessariamente abandonar a ótica perpetrada por um discurso da época - o da resistência, que a via como símbolo ameaçador da identidade musical "genuinamente" brasileira. Eduardo Visconti localiza essa resistência já nos anos 1930, quando as referências à guitarra aparecem em encartes de discos, mas frequentemente o instrumento era confundido com violão elétrico. Não se tratava de uma questão técnica, mas de recusa ao instrumento estrangeiro:

Percebe-se que o surgimento da guitarra elétrica na música brasileira foi acompanhado de um certo "estigma", possivelmente devido a sua forte identidade com a música americana. Esse instrumento também era identificado como referência de modernidade, fato que incomodava alguns críticos e jornalistas preocupados com a "tradição" do violão. (Visconti, 2009)

O autor cita um artigo da Revista da música popular (1954, n.1 apud Visconti, 2009) no qual se confessa o repúdio ao que chama de "violão elétrico", mas que Visconti identifica como guitarra. Temos que, não obstante a guitarra já fosse utilizada por músicos brasileiros desde os anos 1930, com nomes como Garoto, Laurindo de Almeida e Zé Menezes figurando entre os pioneiros, a rigor seu uso era esporádico e em geral utilizado dentro da lógica do violão.

Em certo sentido, até hoje a resistência à guitarra na música brasileira prevalece. Ver um show de música brasileira no exterior em geral vem marcado pelos estereótipos consolidados 
por este ponto de vista; raramente veríamos alguém associar o rock feito no Brasil dos anos 1960 ou 1970, por exemplo, com o que se entende por música popular brasileira. A escassez de estudos sobre as bandas de rock brasileiras dos anos 1950 aos 1970 é outro sintoma disso.

Desse modo, para vislumbrar um pouco sobre os efeitos da introdução da guitarra na discussão da identidade brasileira, seria preciso lançar um olhar que privilegiasse também as interações, as trocas culturais então existentes e que se concretizaram na mudança das feições da música popular brasileira, entendendo este último termo como expressão de uma multiplicidade de expressões artísticas que não podem ser simplesmente reduzidas àquela do "nacional-popular".

Olhemos, assim, para o rock brasileiro dos anos 1960 e 1970, quando a guitarra desponta como instrumento no Brasil.

\section{Um estilo universal}

Abandonando a simples ideia de apropriação, pensamos que o caso é de espaço compartilhado, como afirmamos, um espaço que é parte da cultura midiática. A apropriação existe, não negamos isso, mas gostaríamos de sugerir que a reflexão sobre a introdução da guitarra no Brasil siga essa orientação que abandona a defesa das singularidades nacionais, como sugere Schwarz.

Em vez de perguntar: o que resta de brasileiro nisso tudo? O que nós fazemos com o que vocês nos dão? Como poderemos resistir? E onde estão essas resistências? Questões em que não raro fica implícita uma relação de poder entre as duas partes, herdada da condição colonial e remontando à concepção de centro-periferia que aqui queremos abandonar em favor do estudo das imbricações entre os espaços culturais nacionais (Espagne, 2012), poderíamos arriscar a lançar outras perguntas: existe algo em 
comum entre essa juventude brasileira e a do resto do mundo? Isso tem algum impacto na música que fazem e ouvem?

Não se trata de retomar as abordagens que privilegiam as mestiçagens para definir o caráter brasileiro, afinal, como vimos o que prevaleceu nessas tentativas de definição foi a concepção do "nacional por subtração". A "antropofagia” do modernismo local soube bem responder às questões da apropriação, linha esta retomada, entre outros, pela Tropicália. Parece que existiram três tipos de recepção à guitarra: a rejeição, bem representada pela passeata contra a guitarra; a absorção por aqueles que, embora utilizem o instrumento, adaptavam-no para tocar músicas como samba, cuja estrutura musical difere do rock ou jazz, como, por exemplo, Caetano Veloso; e a aceitação plena, incluindo o tipo de música que vinha a reboque do novo instrumento, o rock.

Este último grupo inclui bandas cujo repertório é muito comercial (jovem guarda nos anos 1960, o rock-pop dos anos 1980), até mesmo por aquelas que apresentam leituras muito sofisticadas e originais dos temas anglo-saxões.

Antes, porém, de nos atermos a estes diferentes grupos, cabe observar que a crítica ao rock e à guitarra não foi exclusividade brasileira.

Nos EUA, em 1965, a reação à primeira aparição de Bob Dylan com uma guitarra (então considerado emblema do gênero folk com a música Blowin' in the Wind) causou escândalo e feriu os brios da música country como representante da identidade norte-americana - isso apenas dois anos antes da passeata brasileira contra esse instrumento.

Agora, em 1965, seu show daria fim a todas as apresentações no festival folk. Após uma noite de ensaios e uma tensa passagem de som na tarde da apresentação, Dylan vestiu uma jaqueta de couro preta e empunhou sua lustrosa guitarra Fender de corpo maciço para o clímax do evento, o show principal, na noite de domingo. 
(...) Dylan subiu ao palco principal na companhia do guitarrista prodígio de blues Mike Bloomfield, do organista Al Kooper, do pianista Barry Goldberg, do baixista Jerome Arnold e do baterista Sam Lay. A multidão foi pega de surpresa, imaginando se aquilo era uma piada, mas a banda não deu muito tempo para eles pensarem sobre o assunto. Ele decolou com "Maggie's Farm", os riffs de guitarra emitindo guinchos e grasnidos por meio dos amplificadores sobrecarregados e falhos. Dylan era uma pantera no show dos gatos da paróquia. $\mathrm{O}$ volume era de arrebentar os ouvidos. As pessoas começaram a gritar, berrar e vaiar. Oscar Brand disse que "a guitarra elétrica representava o capitalismo, as pessoas que estavam se vendendo”. (Epstein, 2012, p.175)

A resistência contra a guitarra ainda encerra a condenação da rebeldia associada ao rock, o que trouxe problemas para seus adeptos não só no contexto da ditadura militar brasileira, em que indivíduos fora dos padrões do trabalhador médio eram alvos constantes de desconfiança, como também causou uma reação generalizada em vários países do mundo que viam nos roqueiros uma espécie de encarnação a um só tempo fáustica e dionisíaca.

A emergência da juventude como categoria - o adolescenteno pós-guerra colocou em xeque a autoridade dos adultos que viam nessa nova categoria criada pelos publicitários uma ameaça não só ao seu status quo, mas a toda uma série de crenças a que estavam apegados. Não tardou a ser feita, assim, a associação entre os fatores que originaram essas tensões sociais e o suposto poder manipulador das mídias como os discos, o rádio, o cinema, as revistas de ídolos e todo tipo de produto da indústria fonográfica incluindo, claro, a música em si - o rock - e a guitarra elétrica, seu instrumento por excelência, com seu excitante, espetacular, ensurdecedor e enlouquecedor som amplificado. Na busca de um bode expiatório que justificasse os novos rearranjos culturais ocorridos no seio da sociedade, os produtos da cultura midiática 
foram diversas vezes tidos como culpados, como sabemos, e com o rock não foi diferente.

As angústias acerca dos jovens se multiplicam cada vez que se produz um questionamento das relações adultos/crianças/adolescentes que tem suas origens, de fato, fora da mídia. A difusão em massa das HQ coincide com o surgimento da criança como um consumidor menos dependente dos pais. O advento do rock coincide com a emancipação adolescente, ela mesma provocada pela emancipação em massa e pelo desenvolvimento de um hedonismo nessa faixa etária (devido ao aumento do tempo livre e dos recursos financeiros, do período de latência social em que é possível se dedicar a uma vida festiva...). (Maigret, 2010, p.80)

Portanto, não foram fenômenos exclusivos do Brasil nem a associação de rock (e de seu instrumento símbolo) com rebeldia, nem a recepção negativa da guitarra nos cantões da resistência contra a corrupção da autêntica música popular. Menos ainda a expansão do rock como gênero. Já nos anos 1950, podemos ver bandas de rock se espalharem não só pelo hemisfério norte, mas também pela África e América Latina, incluindo o Brasil. A recepção no Brasil também obedeceu a essa lógica e só pode ser compreendida nesse contexto.

A emergência de uma nova sensibilidade no pós-guerra afetou grande parte do planeta. No que diz respeito ao contexto brasileiro, foi central a participação dos jovens naquele curto período democrático que antecedeu os eventos de 1964. As manifestações públicas por uma nova ordem social também encontraram espaço nas mais variadas expressões artísticas, da música de protesto ao estilo rebelde rock'n'roll. A Ditadura, portanto, aparece aí como fator repressivo desse clima efervescente, mas não consegue mudar completamente o rumo da integração cultural propiciada pela difusão da cultura midiática. 
Vimos como entre o grupo que se identificava como representante da MPB havia uma divisão: aqueles que não só resistiram à guitarra como também protestaram abertamente, $\mathrm{e}$ aqueles que a absorveram, deglutindo-a antropofagicamente, e a utilizaram para a própria MPB.

Na primeira postura havia um elemento mais ligado à questão ideológica e também à briga pelos mercados. Mas certamente, ela encontrou grande adesão entre o público por reunir nomes muito populares da música então largamente difundida pelo rádio e TV, e também porque já havia um campo fértil para a resistência à atitude rocker não só no Brasil como no mundo.

No segundo grupo, incluem-se nomes que ficaram famosos na indústria cultural brasileira como representantes da MPB, a exemplo dos músicos baianos que se tornaram parte de uma espécie de panteão musical brasileiro.

O último grupo, que aceita e adota a guitarra como instrumento e o rock como música e estilo de vida, ficou polarizado, ora associado ao estilo comercial, ora ao underground.

\section{Nacional ou estrangeiro?}

Antes de começarmos a dividir em alguns grandes grupos os sucessivos movimentos artístico-musicais que podem ser associados à introdução do rock no Brasil, gostaríamos de observar o que entendemos como rock.

De maneira muito ampla, além do ritmo musical que provém do blues americano e que é tocado de maneira acelerada e amplificada, o rock também emana um estilo de vida outsider, rebelde e antissocial. Que ele tenha sido absorvido pela indústria cultural e que tenha se tornado mainstream, anulando seu sentido de contestação e rebeldia, não temos dúvida. Bem como poderíamos afirmar que o mesmo tipo de mecanismo pode ser 
observado com o blues e o jazz (Hobsbawm, 1990, p.86) ou, posteriormente, com o rap ou com o punk rock, ${ }^{7}$ e outras manifestações musicais que compartilham de alguns dos mesmos ideais e estilos pautados pela resistência e rebeldia, mas que com o passar do tempo tornaram-se mero entretenimento, esvaziados de seu sentido contestador.

Da mesma forma, gostaríamos de nos situar cronologicamente, pois, na memória do rock no Brasil, em muito prevaleceu a versão de uma geração vencedora, como de resto acontece sempre quando falamos em construção da memória. A versão predominante situa a primeira grande eclosão do rock nacional nos anos 1980, com a qual não concordamos. O papel do intelectual é questionar e não simplesmente tomar como verdade entrevistas e depoimentos. No lugar da problematização, porém, o que temos visto é uma certa glamorização de uma geração que era criança ou sequer tinha nascido quando as primeiras bandas de rock apareceram no Brasil, nos anos 1950. Nos anos 1960 e 1970 elas se multiplicam e o gênero ganha cada vez mais espaço a ponto de gerar resistências como a passeata a que nos referimos.

No início, alguns grupos cantavam em inglês e reproduziam o estilo mais comercial. Mas com o passar do tempo muitas bandas emergem com uma postura mais underground e já com feições bem brasileiras: temas, atitude e até particularidades no estilo, reivindicando, inclusive, a existência de um rock brasileiro. E se estas são até hoje em grande parte ignoradas pelo grande público e pela crítica acadêmica, certamente é menos por sua inclinação à rebeldia que pela versão predominante de que o rock no Brasil

7 Embora não estejamos completamente de acordo com a análise do punk rock feita por Stewart Home, alguns dos aspectos abordados em seu livro nos parecem bastante pertinentes, tais como a ligação entre o movimento punk e contracultura e à sua absorção pelo mercado em fins dos anos 1970: "Um dos problemas enfrentados pela blank generation - que a geração dos anos 1960 não precisou superar - foi uma cultura jovem e pós-jovem institucionalizada. [...] Assim, a ampla base social que poderia ter se desenvolvido foi, no lugar disso, enfraquecida e destruída” (Home, 1999, p.131). 
só ganha espaço na geração de 1980. Ora, o que vemos, porém, é que esse dito rock que nos anos 1980 ganha as rádios, revistas, programas de auditório etc. e que até hoje mantém alguns de seus representantes em evidência na mídia, não é senão uma fase em que o rock já se populariza, torna-se pop, e perde em grande medida seu poder de rebeldia. ${ }^{8}$

Não é esse o rock que nos interessa, mas sim, o daquelas bandas que, adotando a guitarra, tiveram que tomar uma atitude defensiva frente ao cenário pouco favorável que ia desde a precariedade técnica da época (dificultando o acesso de instrumentos, equipamentos e discos importados), até a resistência social, marcada pela ditadura e pela sensibilidade moral, passando, naturalmente, pela campanha de grupos que eram contra a guitarra. E sempre tendo como horizonte a consciência de estarem fazendo música brasileira, mesmo que de inspiração anglo-saxã que, a esta altura, já poderia ser chamada de música universal, dada sua expansão extraordinária.

Se com as bandas dos anos 1950 e 1960 a guitarra tem um segundo momento na história da música brasileira, ${ }^{9}$ é com os grupos dos anos 1970 que ela é explorada em toda sua potencialidade de instrumento amplificado eletricamente, com uma ati-

8 E mais, essa memória da geração do "rock anos 1980" parece ter conseguido, ainda, anular não só manifestações do rock dos anos 1960 e 1970, mas também as bandas mais radicais de punk e heavy metal contemporâneas. Algumas dessas bandas, como Legião Urbana, usaram fartamente o argumento de que começaram como "banda punk" como defesa das acusações de serem "vendidas” para indústria cultural. Usado como um mecanismo de legitimação, o "ato original" desta e de outras bandas vem sempre marcado por um passado mítico underground que quase nunca corresponde à realidade.

9 Segundo Visconti, é com este segundo grupo que o rock começa a ser tocado, tendo os anos 1970 como marco da incorporação da guitarra ao que ele chamou de "nova música popular brasileira". Embora ele cite o movimento da Jovem Guarda ou o papel de Sérgio Dias, d'Os Mutantes e seu irmão Cláudio Dias na difusão do gênero no Brasil, sua intenção é destacar nomes que adaptaram a guitarra à música nacional como Lanny Gordin ou Pepeu Gomes (Visconti, 2009, p.11). 
tude ainda mais rebelde de seus integrantes, o que se concretiza em sua não aderência ao mercado, como ocorreu com a Jovem Guarda. Utilizando-se de suas referências originais, ou seja, as músicas americanas e inglesas, o rock começa a ser tocado no Brasil sempre tendo que enfrentar essa censura contra o fato de não ser "autenticamente" brasileiro.

Outro fator a ser destacado, é a crescente profissionalização da indústria fonográfica com a entrada de grandes gravadoras que mudarão o cenário da indústria musical (Janotti Jr., 2003, p.61). Grande parte dos grupos de rock a que nos referimos estava fora desse circuito, e esse fator é importante para termos em mente como toda uma cena paralela se forma despeito do apoio das grandes gravadoras mais interessadas em agradar ao público que arriscar-se em terreno movediço. Entre as bandas temos muitos exemplos: Fevers, Joelho de Porco, Secos e Molhados, Tutti Frutti, Mutantes (várias de suas músicas dialogam com a Tropicália, eles são parte do movimento, mas há outras músicas que são completamente rock), Terço, A Bolha, Terreno Baldio, O Som nosso de cada dia, O Peso, Casa das Máquinas, Rita Lee etc.

Era um movimento bem antenado com o que ocorria fora do Brasil, mesmo com todas as dificuldades impostas tanto pelas restrições técnicas dos meios de comunicação, quanto pelo momento político, sendo precursor de uma tendência que logo revelou-se inevitável e incontornável: a globalização. Isso exigia certa sofisticação que normalmente não é atribuída ao rock.

Veja abaixo a transcrição do depoimento do jornalista Chico de Assis, também extraído do documentário Uma noite em 67:

Eu participei de uma passeata contra a guitarra elétrica ao lado de Gilberto Gil. Gil aqui e eu aqui: "Fora as guitarras! Fora as guitarras!" A gente não queria a guitarra elétrica. Eu sabia bem porque eu não queria. Eu sabia que o som da guitarra elétrica, [que] atrás 
dele tinha um monte de lixo de rock americano pronto para desembarcar no Brasil. Não era um Zappa não, nem Zeppelin, era outra coisa. Chico de Assis, Uma noite em 67 (2010)

O que ele destaca é o componente comercial do rock então tocado no Brasil, "o lixo americano", citando como contraexemplos bandas de rock progressivo. Uma das bandas que parecem ter respondido a tais críticas é a Casa das Máquinas. Formada em 1974 com integrantes que faziam parte da Jovem Guarda, como Pique, que tocava órgão para Roberto Carlos, Pisca, que tocava na Som Beat, de 1965, ${ }^{10}$ Aroldo e Netinho do grupo Os Incríveis, ${ }^{11}$ banda formada no início dos anos 1960. Seu baterista, por sua vez, o Nenê, tinha tocado em uma das primeiras bandas de rock brasileira, The Rebels (que também cantava em inglês), de 1959; ele tinha esse apelido por ter começado a tocar com 12 anos, sendo o mais novo da banda.

No disco do grupo Casa das Máquinas, intitulado Casa de Rock, de 1976, a capa continha o aviso "Brazilian Rock", como a exigir sua identidade brasileira. A música Londres, por exemplo, é um hard rock com todos os elementos do estilo inglês, que narra a experiência de um brasileiro pela primeira vez em Londres:

\footnotetext{
Quando em Londres cheguei a fog cobria toda cidade

Nunca imaginei tanta loucura em tão pouca idade

Um toque de rock em cada esquina

Lord lady louco no subway

É um mal que contamina

Esse privilégio me fazia sentir um rei
}

10 Ouça a música "Sou tímido assim" em: <http://www.youtube.com/ watch? $\mathrm{v}=4 \mathrm{DuUBlpI} 4 \mathrm{Mg}>$. No mesmo "compacto", único do grupo e gravado em 1967, vem uma versão da famosa banda de rock inglesa The Who, My Generation (Fróes, 2000).

11 Ouça em: <http://www.youtube.com/watch?v=TBppY779y24>. 
Lord lady louco no subway

Londres se anuncia, Londres se anuncia

É rock de noite e de dia

Londres se anuncia, Londres se anuncia

Rock de esquina

Você não imagina

Uma nova atitude herdei

Londres se anuncia, Londres se anuncia

Rock de noite e de dia ${ }^{12}$

Mas essas trocas culturais não se dão apenas por meio de pessoas que viajam e importam um estilo, "herdando" uma nova atitude - nova em relação ao que se passava no Brasil, tanto no que diz respeito à música brasileira chamada de $\mathrm{MPB}$, quanto ao que se refere ao rock tocado por aqui, bem comercial como vimos. E, ao contrário do que diz Chico de Assis, essa música que já começa com um solo muito marcado de guitarra, além de sofisticada, certamente dialogava com o rock progressivo a que ele se referia como de boa qualidade. Era uma espécie de reação das bandas brasileiras à ideia de que a guitarra não poderia estar presente na música popular brasileira. E nesse caso vemos claramente como essa condição é reivindicada, uma vez que a letra é em português e fala da experiência de um brasileiro em Londres.

Outro exemplo é a banda Made in Brazil. A começar pelo nome, que também reclama a sua identidade brasileira, como ocorre com a Casa das Máquinas, apesar de escrito em inglês. Um de seus discos, inclusive, chama-se Pauliceia desvairada, referência explícita ao modernismo e à atitude de apropriação dessa cultura globalizada. Formada no bairro da Pompeia, na São Paulo de 1967, passa a ter repertório em português em

12 Ouça a música em: <http://www.youtube.com/watch?v=Ugtk4MHk_uA>. 
1973. ${ }^{13}$ A música O rock de São Paulo do disco Jack o estripador de 1976 fala da aclimatação do rock americano no Brasil:

Eu não sou de Memphis e nunca fui para lá

Mas gosto de Chuck Berry e de tudo o que ele faz

Dele e de Jerry, Jerry Lee Lewis

É um balanço que nunca se ouviu...

Esses caras infernais, fazem até o diabo dançar...

Eu não sou de Memphis, mas gosto de um rock

Eu sou da Pompéia, a barra da cidade...

Tocamos muito rock, para a todos ouriçar

É o rock de São Paulo, que faz surdo escutar

Esses caras infernais, fazem até o diabo dançar... ${ }^{14}$

A referência aqui são os Estados Unidos e o berço do blues e do rock, Memphis. Sempre sob a perspectiva de um brasileiro que quer ser reconhecido como roqueiro embora não seja americano (ou inglês, como no caso anterior), fala de um rock "paulistano". Feito em São Paulo, tocado por paulista e, por isso, não menos legítimo como expressão musical, nem menos brasileiro. Sem almejarem uma singularidade expressamente brasileira para sua expressão artística, tais músicos também não se colocam como aqueles que apenas copiam o estrangeiro: eles se percebem como parte integrante de um movimento mais amplo, que ultrapassa os limites da nacionalidade, ratificando o caráter de fusão de elementos que sempre foi característica da música local.

Outros exemplos seriam possíveis, mas os dois acima já são suficientes tanto para questionar a classificação do rock brasilei-

13 Ver site da banda em: <http://www.bandamadeinbrazil.com.br>.

14 Ouça a música em: <http://www.youtube.com/watch?v=yyL8ydyk4Pg>. 
ro e da adoção da guitarra elétrica por seus músicos pela chave que exclui do "nacional" tudo o que não é nativo.

\section{Considerações finais}

Existe, afinal, um espaço compartilhado entre cultura anglo-saxã e brasileira (ou, mais amplamente, à cultura jovem mundial) no que diz respeito a essas bandas de rock, ou tudo é mera cópia? Seria um efeito da globalização com a criação de um espaço comum ou seria apenas uma importação a mais da "cultura gringa"?

Pensamos que se formos contra o "mito da origem" tão presente nas reflexões sobre cultura popular, nossa resposta só pode ser aquela que vê nesses artefatos culturais o resultado de uma intensa interação que, para além da apropriação, revela um espaço comum que ultrapassa as fronteiras nacionais.

Seria necessário explorar mais essa questão da juventude como categoria universal no pós-guerra e situar melhor essas expressões culturais - inclusive musicais - nessa perspectiva não só para compreender as singularidades do caso brasileiro, mas também o que ele apresenta de comum com o que se passa em termos mundiais, deixando de lado um pouco as tensões geradas pelas relações assimétricas geradas no seio dos contatos internacionais para privilegiar as imbricações.

Definitivamente a música internacional tem um profundo impacto na música brasileira, não só na contemporânea, mas, sobretudo nesta, devido às condições tecnológicas. E, se a defesa das singularidades passa a ser um "tópico vazio" a partir do processo de internacionalização, como já foi explicado por Roberto Schwarz, resta-nos desvelar o processo que permite as interações.

Ao mesmo tempo, devemos nos livrar daquela confusão corriqueira entre tecnologia e produto, como ocorreu entre a guitar- 
ra e o rock. A guitarra, simboliza, assim, a irreversibilidade do contato com uma cultura que se torna cada vez mais hegemôni$\mathrm{ca}$, sim, mas que penetrou o mercado e mentes brasileiros. Este contato constitui-se, portanto, em um fenômeno a ser observado pelo estudioso da cultura.

A passeata contra a guitarra, aqui, ficaria como um símbolo desta resistência a tudo o que é estrangeiro, marcada na concepção do "nacional por subtração" que parece sobreviver não só nas mentes daqueles que ainda veem o rock brasileiro apenas como cópia de um padrão cultural estrangeiro, em tudo estranho à nossa cultura "tradicional" ou "autenticamente brasileira" (entendida como superior, mais sofisticada, mais madura, mais engajada etc.) tal raciocínio parece ter grande ressonância na crítica, que pouco se debruçou sobre este objeto, menos ainda para investigar a identidade do brasileiro, como se esta só pudesse ser homogênea, ou, na melhor das hipóteses, mestiça, mas nunca universal. 


\section{Brasil: três projetos de identidade religiosa}

Artur Cesar Isaia ${ }^{1}$

\section{Introdução}

As ciências humanas têm como objeto uma realidade sempre construída, nunca imóvel nas suas heranças culturais, nas múltiplas formas de sociabilidade a que homens e mulheres estão sujeitos. Nessa construção apela-se, sobretudo, para operações de nomeação da realidade, que são sempre históricas, efêmeras, contrárias à ilusão de congelar o tempo. Assim, as identidades são vistas como construções, como projetos, cujo percurso temporal trai o sonho da impressão de um sinete indestrutível de seus agentes. Não existe projeto de nomeação da realidade imune à diacronia, esta sempre disposta a mostrar que a fixidez voluntarista está contraposta ao decurso temporal, às transformações históricas.

As identidades religiosas não fogem a essa fluidez histórica, contraposta à fixidez ilusória dos projetos identitários. Essa dualidade entre projetos redutores da realidade e transformação histórica é particularmente visível no mundo contemporâneo

1 Professor associado do Programa de Pós-Graduação em História da Universidade Federal de Santa Catarina (UFSC). E-mail: isaia@cfh.ufsc.br. 
caracterizado pela simultaneidade das informações e pela diluição de fronteiras dos projetos identitários. Particularmente no Ocidente, marcado por uma acentuada marcha do pluralismo religioso, fica evidente, em nossos dias, a multiplicação das possibilidades de interpelação religiosa e de arranjos pessoais, capazes de aprofundarem o subjetivismo religioso proposto por Dumont (1983), ou a "religiosité flottante" proposta por Champion (1993). Esses processos anulatórios dos projetos de identidades religiosas fixas, talvez sejam a acentuação contemporânea de uma realidade de longa duração, a catalisação das oposições que marcaram os discursos (particularmente dos monoteísmos abraâmicos) da salvação, da eleição, da profecia alçada à religião, contra a presença dos não seduzidos ou convertidos. Esse foi um processo que, no Ocidente, opôs a identidade, tanto embasada na lógica formal, como princípio de captação da realidade e de criação do conhecimento, quanto o projeto da cristandade medieval, oposto à multiplicidade de vivências da fé, que, para muito além da reforma protestante, contradiziam o projeto de uma igreja completamente hegemônica, na qual suas normas canônicas se impusessem como normas sociais (Ginzburg, 1987, 1977; Sell; Brüseke, 2006).

A chegada do projeto de cristandade ao Brasil e a implantação do antigo sistema colonial acentuaram as coordenadas da oposição, já existente na Europa, entre a fixidez do projeto identitário católico e uma realidade sociocultural marcadamente plural. Particularmente à Península Ibérica, Gilberto Freyre mostrava a contradição entre o projeto de cristandade e a multiplicidade de significados partilhados, acentuada com a expansão africana e a convivência com negros, judeus, mouros, ciganos. As vivências culturais chegavam às características fenotípicas, marcando a mestiçagem como realidade física e cultural (Freyre, 2007). Particularmente, referindo-se à América Hispânica, Canclini ressalta o que chama de hibridização, como fenômeno capaz de gerar uma "mestiçagem interclassista", responsável por "formações híbridas em todos os estratos sociais" (Canclini, 1992, p.71). Igual- 
mente em relação à América Hispânica, Todorov mostra que as noções de identidades estáveis opõem-se a um eu historicamente formado de maneira relacional, impossível de ser compreendido sem a recorrência aos universos simbólicos e axiológicos, capazes de levar à superação da pura e simples alteridade (Todorov, 1982).

Desfazendo o essencialismo da ideia de identidade, os estudos de Bourdieu vão claramente ao encontro de uma construção, de um projeto identitário, integrado às operações de nomeação da realidade que marcam a divisão "legítima" do mundo social. Referindo-se à construção social de fronteiras geográficas ou socioculturais, refere-se Bourdieu:

Ninguém sustentaria hoje a existência de critérios capazes de fundar classificações "naturais", em regiões "naturais" separadas por fronteiras "naturais". A fronteira nada mais é que o produto de uma divisão à qual se atribuirá maior ou menor fundamento na "realidade" [...] Mas isso não é tudo: neste caso, a "realidade" é social de alto a baixo, e mesmo as classificações mais "naturais" apoiam-se em traços que não têm nada de natural, sendo, em ampla medida, o produto de uma imposição arbitrária, quer dizer, de um estado anterior da relação de forças no campo das lutas pela delimitação legítima. (Bourdieu, 1996, p.109-110, grifos nossos)

Da mesma forma Berger e Luckmann defendem que a realidade humana só pode ser compreendida atendo-nos ao caráter histórico com que foi construída. Isto quer se pense no que aparece como dado "objetivo", quer se pense no mundo simbólico. Assim, as identidades como criações, deveriam ser compreendidas enquanto construções sociais, humanas antes de tudo. Referindo-se ao objeto humano da sociologia e suas interações com a história e a filosofia, Berger e Luckmann justificam: "Este objeto é a sociedade como parte de um mundo humano, feito pelos homens, habitado por homens e, por sua vez, fazendo os homens, em um contínuo processo histórico" 
(Berger e Luckmann, 2011, p.239). Assim, referendam a concepção de Bourdieu sobre o caráter, a um só tempo, estruturante e estruturado dos sistemas simbólicos. Neste sentido, as identidades, tomadas como sistemas simbólicos integram o projeto de estabelecer uma verdadeira ordem gnoseológica. Ou, em outras palavras, uma forma que se quer "legítima" de percepção e classificação do mundo (Bourdieu, 2001, p.9), a qual deve ceder lugar à reflexão histórico-sociológica.

Neste texto, vamos privilegiar a religião como discurso que tenta instituir projetos de identificação com a realidade nacional. Para isso escolhemos três projetos, três narrativas de instituição de uma identidade religiosa no Brasil: o projeto católico, o umbandista e o pentecostal. São discursos claramente enfáticos, não só na sua tentativa de qualificar a identidade do referente Brasil a partir do viés religioso, mas, igualmente, na tentativa de "ler" a história nacional sob um viés providencialista, capaz de endossar e tornar legítimo o esforço identitário.

\section{O projeto de um Brasil católico: a hierarquia eclesiástica da primeira metade do século $X X$}

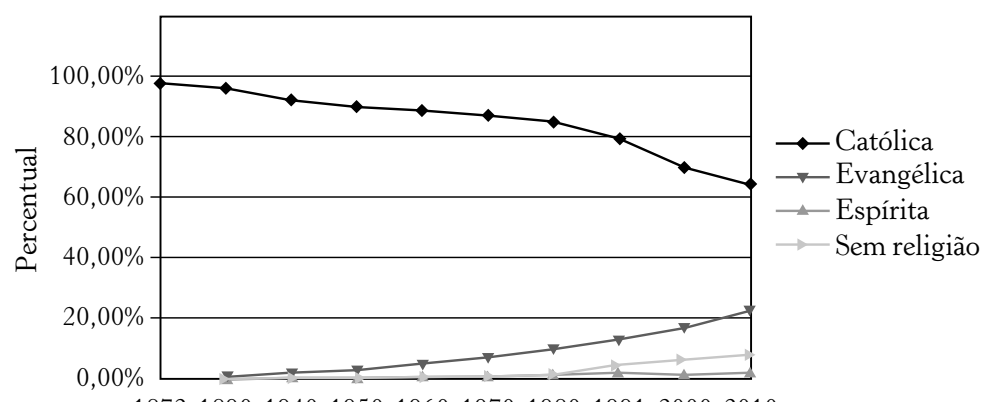

1872189019401950196019701980199120002010

Ano

Gráfico 1: Distribuição religiosa da população brasileira desde 1872 Fonte: IBGE. 
O projeto de uma identidade católica para o Brasil foi enormemente facilitado pela unanimidade religiosa existente até a primeira metade do século XX. O primeiro recenseamento feito no Brasil, em 1872, indicava essa situação de extrema comodidade no campo religioso, expressa em 99,7\% da população brasileira dizendo-se católica. Desde a criação do Instituto Brasileiro de Geografia e Estatística (IBGE), em 1936, essa unanimidade vai sofrendo a investida de outros agentes no campo religioso brasileiro, chegando os católicos a 89,9\% da população em 1980 , número que despenca aceleradamente nas duas décadas seguintes, chegando a 64,6\% no censo de 2010 (IBGE, s.d.).

A primeira metade do século XX não deixa dúvidas de que a população brasileira, embora majoritariamente católica, começava a acentuar a diversificação religiosa. Escolhemos justamente esse lapso temporal para enfocarmos o projeto católico de investida contra o processo de diversificação religiosa em curso, tentando aprofundar a ideia de uma "essência" católica para o Brasil. Nosso corpus para este estudo centra-se, sobretudo, na documentação da hierarquia e laicato da Igreja Católica no período. Em muitos desses documentos vamos encontrar uma ideia que se repete: a da linearidade que unia o Brasil a Portugal através da fé católica. Um desses documentos é a "Carta Pastoral Coletiva de 1922”, publicada por ocasião do centenário da independência brasileira. Os bispos liam o descobrimento do Brasil como uma etapa do esforço lusitano em dilatar a cristandade, em uma conjuntura hostil a esta e que culminaria na reforma protestante do século XVI. O Brasil surgia como baluarte da investida da Igreja Católica contra seus inimigos, tentando dilatar a igreja militante, através da conversão do gentio. A América Lusitana aparecia para a história através da primeira missa, portanto, através do sacrifício eucarístico, capaz de trazer o próprio Cristo 
em corpo, sangue, alma e divindade, "integrum Christum" para a "Terra de Santa Cruz". Os bispos brasileiros escreviam que a cruz erigida pelos portugueses para a primeira missa marcava o princípio da "posse" cristã sobre o Brasil: "Ei-lo o descobridor do Brasil, levantando para perpétua memória da posse divina o glorioso padrão que há vinte séculos marca as conquistas do Filho de Deus" (Episcopado Brasileiro, 1922, p.4). Na visão dos bispos, a ereção da cruz para o sacrifício eucarístico marcava o verdadeiro "uti possidetis" do catolicismo sobre o Brasil. A partir daí, o país deveria ser pensado como católico, ratificando sua história esta ligação. Através do discurso da obviedade providencial de um "Brasil católico", a hierarquia empreendia o projeto vislumbrado por Bourdieu, de "fazer ver a alguém o que ele é" (Bourdieu, 1996, p.97-106), projeto ainda exequível no Brasil da primeira metade do século XX, pela riqueza da acumulação simbólica da igreja e pela situação de comodidade que desfrutava frente ao campo religioso brasileiro. Essa operação simbólica aparecia em D. Carlos de Vasconcelos Motta como uma "predestinação providencial", vinda de "seu místico berço, que foi no regaço eucarístico da primeira missa em Porto Seguro" (Motta, 1955, p.235).

Por outro lado, a identidade brasileira católica era assumida, conciliando-a com a visão triádica da nacionalidade, proposta desde o século XIX por Varnhagen; visão esta, na qual, ao reconhecimento do negro e do índio como formadores da nacionalidade, somava-se o papel coordenador do gênio lusitano (Isaia, 2011, p.31). Conforme referimo-nos em outro trabalho, em relação ao período estudado: "assumindo totalmente a visão formadora da nacionalidade a partir da ideia das três raças, sob a preponderância branca lusitana, são inúmeros os pronunciamentos de clero e laicato" (Isaia, 2003, p.243). Isto é particularmente

2 A expressão aparece no Cânon 3 do Concílio Tridentino. Ver: Giraudo (2003, p.444). 
importante em um momento em que se repensava a identidade e a nacionalidade, apelando-se para o sincretismo como chave analítica. A obra de Gilberto Freyre é altamente emblemática desse repensar da nacionalidade, no qual a persistência da visão triádica e da própria ascendência lusitana mostrava uma linearidade evidente com a visão de Varnhagen, endossada por uma parte do Instituto Histórico e Geográfico Brasileiro, ao mesmo tempo que se afastava das representações racistas e pessimistas do final do século XIX (Isaia, 2012, p.2). A ascendência lusitana sobre as "três raças" formadoras da nacionalidade aparecia no discurso da hierarquia eclesiástica brasileira ainda em meados do século XX, acenando para a ficção de uma pureza étnica e religiosa no passado português. Assim, para o cardeal Motta, o Brasil teve "uma origem nobre e eugênica, filho que é e bem nascido, da católica estirpe portuguesa, daqueles heroicos civilizadores e evangelizadores 'que a fé e o império iam dilatando' em cada uma de suas conquistas, através dos mares e continentes" (Motta, 1955, p.235). D. Aquino Correa, já ressaltara, não só a propalada representação triádica da nacionalidade brasileira, como, à maneira de Varnhagen, via a expulsão dos "hereges" holandeses do Nordeste brasileiro no século XVII como o prelúdio da formação histórica nacional, com negros e índios lutando sob a atividade comandante do português. A expulsão dos holandeses do Nordeste adquiria uma conotação épica, buscando o arcebispo no mundo clássico o modelo capaz de dar sentido, tanto à história lusitana quanto à brasileira. $\mathrm{Na}$ "ilíada nacional" reforçavam-se as representações do Brasil católico e linearmente ligado a Portugal:

Far-vos-á ele ver no brasileiro, um povo talhado para mais severos hábitos. Os elementos étnicos que o plasmaram são todos de têmpera rija e austera. O índio foi um guerreiro sempre em armas. [...] Bem conhecida é a resistência sofredora do afri- 
cano. E o português, finalmente, foi como sabeis, o único povo do mundo, cujo heroísmo inspirou epopeia tão nacional e verdadeira como Os Lusíadas, a que faltaria, entretanto, o segundo tomo, não menos épico e glorioso, aqui traçado por esse povo de fortes, sobre os mares e sertões misteriosos do ocidente. E foi na luta, foi na guerra holandesa, na ilíada nacional do século XVII, que essas raças, representadas por Poti, Henrique Dias e Fernandes Vieira, fundiram-se ao fogo das batalhas, preparando na história o advento do homem brasileiro. (Correa, 1944, p.163)

Na década de 1920, o intelectual católico Jônatas Serrano cantava a "redenção" dos indígenas via catequese, em poesia dedicada ao cinquentenário da ordenação sacerdotal de D. Joaquim Arcoverde de Albuquerque Cavalcanti, arcebispo do Rio de Janeiro e primeiro cardeal latino-americano. Nessa poesia, Serrano criava um tempo ficcional, no qual conviviam D. Joaquim e dois indígenas cristianizados: Arariboia e Jaguarari. A cristianização desses indígenas, o apagamento do seu passado tribal e politeísta, a aceitação do catolicismo e a disposição em lutar pela causa portuguesa apareciam como fatores capazes de "elevá-los" a uma "condição superior" (Serrano, [s.d.], p.143-144).

De outra forma, o indígena refratário à catequese, rebelado contra a religião católica e a coroa portuguesa é representado com os piores atributos da heresia contumaz. Assim, retomando à Pastoral Coletiva de 1922, os bispos atualizavam o projeto de uma identidade católica nascida da primeira missa, aprofundando a alteridade com o estrangeiro "herege". Este era portador de uma antirrealidade, oposta aos planos da providência divina. Como consequência, analisando a invasão dos franceses no Rio de Janeiro e entre estes a saliente presença calvinista, os bispos contrapunham imagens, nas quais claramente vinham à tona, tanto a "afirmação" da vontade de Deus pela vitória lusitana, 
quanto a desmoralização dos inimigos da fé católica. Reforçando a alteridade com o invasor, dramatizando e simplificando imaginariamente a realidade (Boia, 1998), os bispos mostravam São Sebastião intercedendo vitoriosamente junto a Deus, enquanto os invasores batiam em retirada aconselhado por uma índia. Era a "inegável” ratificação da identidade católica brasileira:

Quando em 1567 nascia a cidade do Rio de Janeiro [...] presidiam à empresa Nóbrega e Anchieta, já aconselhando os destemidos guerreiros, já reclamando de Mem de Sá reforços de naus e homens para a decisiva vitória contra o denodado gentio ao serviço do temerário francês usurpador. Para animar então com sua presença os soldados no combate travado contra os franceses e tamoios, acompanhou-o D. Pedro Leitão, nosso segundo bispo. Com ardente, constante invocação nos lábios ao mártir São Sebastião no dia da batalha, vinte de janeiro, portugueses e índios fiéis heroicamente pelejaram, e ao mesmo tempo que a tradição nos representa de joelhos, mãos postas, um cristão a orar pela vitória das armas de Portugal e uma tamoia a bradar aos seus que fugissem, pois vencidos estavam, também nos mostra pairando sobre as canoas, a comandar a luta e a proteger os seus, belo, robusto, jovem, o glorioso padroeiro do dia. (Episcopado Brasileiro, 1922, p.13)

Ao santo, que capitalizava além da familiaridade com Deus a detenção de padrões morais e estéticos caros ao expansionismo católico português (belo, robusto, jovem), contrapunha-se um ser deficitário simbolicamente através da etnia e do sexo, a anunciar a derrota dos indígenas que ousaram mancomunar-se com o "herege invasor". O discurso da hierarquia católica persiste nesta identificação na qual estado, catolicismo e povo deveriam coabitar em uma nebulosa, capaz de dividir projetos e inimigos. Nesta direção soam muito claras as palavras de D. Sebastião Leme, por ocasião da inauguração da estátua do Cristo Reden- 
tor. Suas palavras são uma advertência a Getúlio Vargas de que o "povo brasileiro" não toleraria afrontas institucionais capazes de ofenderem ao catolicismo:

Banido dos conselhos da nação, Deus [...] terá sempre guarida no coração do povo, mas o estado e, portanto, os seus governantes, estará desamparado de todo o espírito de ordem, respeito e disciplina: jamais poderá firmar-se na paz duradoura e fecunda, porque sem alicerces no amor e consideração dos governados. (Mensagem Do Episcopado, 1931)

É interessante que esta representação do povo brasileiro como "naturalmente católico", contraposto a uma elite indiferente em matéria religiosa e que precisava "converter-se" aproximando-se aos valores do povo, não ficou restrito ao projeto de neocristandade. ${ }^{3}$ Para Pierucci, desde a proclamação da República a hierarquia católica insistiu em contrapor as elites tíbias na fé e obcecadas em aparecer como modernas, ao povo, visto como fiel aos princípios cristãos e católicos (Pierucci, 1996). Da mesma forma Sell e Brüseke salientaram essa persistência, capaz de atingir o próprio discurso da teologia da libertação no Brasil. Para esses autores, o conteúdo conservador da teologia da libertação no Brasil residiu, justamente, nessa incapacidade de reconhecer que um idioma único católico é um projeto de construção identitária, muito distante da realidade empírica, marcada por um acentuado processo de pluralização religiosa (Sell; Brüseke, 2006).

3 Trata-se do projeto de inserção do catolicismo na vida nacional, marcado pela busca de tornar as suas normas religiosas, normas sociais e reconhecidas institucionalmente pelo estado. Por outro lado, baseava-se a mediação do estado e das elites, para atingir os seus desideratos. Ver a este respeito Isaia (1998). 


\section{Os intelectuais da Umbanda e o anúncio de uma religião brasileira}

O projeto de criação identitária de um Brasil umbandista veio ligado a um esforço dos seus primeiros porta-vozes em mostrar a Umbanda primeiramente como uma religião brasileira. $\mathrm{O}$ argumento recorrente era de que, ao contrário tanto da religião majoritária da população brasileira, quanto do protestantismo e do próprio Espiritismo, a Umbanda havia nascido no Brasil, afirmando-se, portanto, como religião nacional.

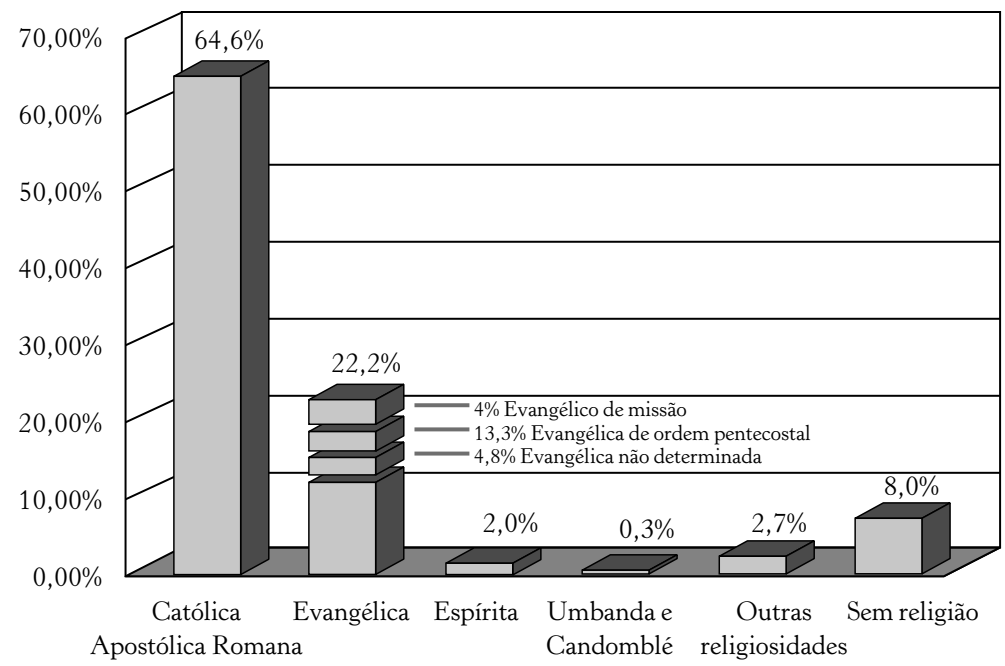

Gráfico 2: Distribuição das religiões no Brasil Fonte: Censo IBGE (2010).

Os números levantados pelo IBGE para o censo de 2010 mostram a diminuta população que se declara adepta do Candomblé ou da Umbanda (0,3\%). Portanto, estamos frente a um projeto identitário que no presente tem contra si, pelo menos no que tange aos números, uma insuficiente credencial social. Os estudos de Ortiz (1988), Brown (1985) e Negrão (1996) evi- 
denciam que o aumento de adeptos da Umbanda aconteceu, sobretudo, entre o segundo quartel do século XX e a década de 1970. Os números levantados por Renato Ortiz mostram um crescimento considerável dos terreiros de Umbanda fundados no Rio de Janeiro, São Paulo e Rio Grande do Sul entre as décadas de 1920 e 1960, atingindo seu pico em meados dos anos 1960, quando começam a decrescer (no caso do Rio de Janeiro e São Paulo a queda era evidente, enquanto que no Rio Grande do Sul, se os números acenavam para um crescimento, este era bem mais modesto) (Ortiz, 1988, p.56-61). Esse aumento das casas de Umbanda acompanha o esforço doutrinário e o projeto identitário de seus primeiros líderes e escritores, no sentido de credenciar simbolicamente a religião.

Os primeiros porta-vozes umbandistas faziam eco à representação miscigenada propalada por parte da intelligentsia brasileira da primeira metade do século XX. O movimento modernista dos anos 1920, particularmente a proposta antropofágica (Queiroz, 1988) e a dimensão teórica alcançada com o discurso do sincretismo por Gilberto Freyre, são momentos emblemáticos dessa projeção de um Brasil mulato, sincrético, marcado por combinações culturais e étnicas. Essas características aparecem, igualmente, na obra escrita desses primeiros porta-vozes da Umbanda, indo ao encontro de qualidades inerentes, para eles, à própria constituição da nova religião. Um dos intelectuais pioneiros da Umbanda, o escritor Leal de Souza, assim manifestava-se a este respeito, em entrevista divulgada na década de 1950:

A Linha Branca de Umbanda é realmente a religião nacional do Brasil, pois que, através de seus ritos, os espíritos ancestrais, os pais da raça, orientam e conduzem sua descendência. O precursor da Linha Branca foi o Caboclo Curuguçu, que trabalhou até o advento do Caboclo das Sete Encruzilhadas que a organizou, isto 
é, que foi incumbido pelos guias superiores que regem o nosso ciclo psíquico, de realizar na terra a concepção do espaço. (apud Trindade, 1991, p.56)

Leal de Souza, nas palavras acima, está fazendo menção a um mito de fundação da Umbanda no Brasil, segundo o qual, em 1908, o espírito de um índio, o Caboclo das Sete Encruzilhadas, teria anunciado ou fundado a Umbanda no Brasil. Zélio Fernandino de Moraes chamava-se o médium, através do qual, muitos umbandistas acreditam ter se manifestado esta entidade. Resumidamente, o mito narra a grave doença a qual teria acometido a Zélio, e a sua cura através da ação do Caboclo das Sete Encruzilhadas. Narra, igualmente, a considerada primeira "manifestação" do Caboclo das Sete Encruzilhadas, a 15 de novembro de 1908, na cidade de Neves, interior do Rio de Janeiro, em sua sessão espírita.

Esta narrativa é aceita por muitos umbandistas como evidência da "fundação" ou "anúncio" da Umbanda no Brasil. Para Giumbelli, contudo, tal narrativa teria adquirido visibilidade somente na segunda metade do século XX, principalmente após a morte de Zélio, ocorrida em 1975 (Giumbelli, 2002). Mais do que a procura pela datação de sua generalização, o que importa neste trabalho é riqueza mítica dessa narrativa. Como na narrativa mítica do "nascimento" do Brasil através da primeira missa, o mito do Caboclo das Sete Encruzilhadas prestou-se ao esforço de pensar, não somente a religião, mas a própria história nacional (Isaia, 1998). Como na narrativa católica, o mito umbandista aponta para uma representação miscigenada, embasada na tríade: negro, índio e branco, na qual não falta, em alguns aspectos, a presença da ascendência do último elemento (Isaia, 2011, 2012).

A lei federal de n.12.644 de 16 de maio de 2012 instituiu o Dia Nacional da Umbanda. Interessante o aspecto de uma com- 
posição gráfica comemorativa à lei. ${ }^{4}$ No interior do mapa brasileiro aparece ao centro uma "gira" de Umbanda, tendo abaixo, à esquerda e à direita, respectivamente, a representação de um Preto Velho, da fotografia de Zélio Fernandino de Moraes, e de uma pintura que evoca o Caboclo das Sete das Encruzilhadas. Os três significantes estão rigorosamente inseridos na tradição umbandista, representando, respectivamente as três "raças" formadoras da nacionalidade, endossando significados de longa duração, caríssimos para a religião. Neste sentido, um dos dirigentes umbandistas históricos, José Álvares Pessoa, assim se manifestava, no final dos 1950, sobre a formação da religião:

Há uns 40 anos mais ou menos, aproveitando a enorme aceitação dos fenômenos espíritas por parte dos brasileiros, entidades que presidem o destino espiritual da raça resolveram levar avante a árdua tarefa de lhes dar uma religião que fosse genuinamente brasileira. Porque, filho de três raças - a branca, a negra e a índia - não era justo que coubesse ao brasileiro, como imposição, uma religião $100 \%$ importada, fosse ela qual fosse, e que não reunisse os anseios das três raças a que pertence. A religião que lhes estava destinada deveria ser uma religião eclética [...]. (Azevedo, 1960, p.63)

Já o mito fundante referente a Zélio Fernandino de Moraes referia-se especificamente à formação de uma religião nacional, na qual espíritos de negros e ex-escravos, que não encontravam guarida no Espiritismo de matriz kardecista no Brasil, poderiam finalmente manifestar-se livremente. Em depoimento datado de 16/11/1971, Zélio de Moraes recordava o instante tido por essa tradição como originário, fundacional da Umbanda no Brasil, corroborando a representação triádica da nova religião:

4 Disponível em: <http://ecaruanda.blogspot.com.br/2012/06/dia-nacional-da-Umbanda-para-noooooossa.html>. Acesso em: 1 jul. 2013. 
Ao meu lado está o Caboclo das Sete Encruzilhadas para dizer a vocês que esta Umbanda, tão querida de todos nós fez ontem 63 anos, que na Federação Kardecista do Estado do Rio, presidida por José de Souza, conhecido por Zéca, rodeada de gente velha, homens de cabelos grisalhos, um dia de Santo Agostinho, chamou o meu aparelho, ${ }^{5}$ chamou, me chamou para sentar à sua cabeceira. Trazia uma ordem, fora jesuíta até aquele momento, chamava-se Gabriel Malagrida. Naquele instante ele ia criar a lei de Umbanda, onde o preto e o caboclo pudessem manifestar, porque ele não estava de acordo com a Federação Kardecista, que não recebia pretos nem caboclos, pois sim o que existia no Brasil eram caboclos eram nativos. Aqui no Brasil quem veio explorar o Brasil trouxe para trabalhar, para engrandecer este país eram os pretos da costa da África, como é que uma Federação Espírita não se recebia caboclo nem preto. Então disse eu, disse o espírito: "Amanhã na casa do meu aparelho, na rua Floriano Peixoto número 30 será inaugurada uma tenda espírita com o nome de Nossa Senhora da Piedade, que se chamará tenda de Umbanda, onde o Preto e o Caboclo pudessem trabalhar". (Moraes, s.d., grifos nossos) ${ }^{6}$

A fala de Zélio Fernandino de Moraes nos fornece indícios importantes para a compreensão da riqueza simbólica da narrativa tida como fundante ou anunciadora da Umbanda por alguns adeptos da religião. Em primeiro lugar aparece o componente nacionalista, presente no projeto identitário. Este nacionalismo tem um conteúdo assumidamente fiel à narrativa da origem triádica da nação. Projeta uma nova religião capaz de celebrar os

5 A expressão refere-se, no vocabulário próprio das religiões mediúnicas, ao médium. No caso Zélio Fernandino de Moraes.

6 Nota-se que, na fala de Zélio de Moraes, há uma confusão na enunciação da mensagem, oscilando entre um narrador humano, ele mesmo, e outro com uma identidade espiritual, o Caboclo das Sete Encruzilhadas: ("chamou o meu aparelho, chamou, me chamou" [...] "Então disse eu, disse o espírito" [...]). 
formadores da nacionalidade, acenando para um interdiscurso bastante próximo ao propalado, tanto pelo Instituto Histórico e Geográfico Brasileiro, através de Varnhagen, quanto pelo assumido pela hierarquia católica da primeira metade do século XX (Isaia, 2011). Não falta o proeminente lugar do branco na narrativa, presente com o jesuíta Gabriel de Malagrida, capaz, inclusive de dotar a nova religião de um crédito simbólico extremamente importante para a aceitação entre as elites: o letramento. Dessa forma, o Caboclo das Sete Encruzilhadas, ora aparecia com os atributos próprios aos antigos donos da terra no Brasil, ora era representado diferentemente, remetendo a uma das suas encarnações como Malagrida.

Nessa narrativa fundante ou anunciadora da Umbanda o papel de Malagrida é fundamental. Ele aparece como um recurso capaz de "afiançar" a "veracidade" da mensagem do Caboclo das Sete Encruzilhadas frente a um meio refratário ao universo cultural de negros e índios, em uma sociedade onde eram evidentes os resíduos estamentais. Desta forma, acontecendo a primeira "manifestação" do Caboclo das Sete Encruzilhadas em uma sessão espírita kardecista, assim aparece o diálogo entre ele e uma "médium vidente"7 presente nela:

Por que fala desse modo se estou vendo que me dirijo, neste momento, a um jesuíta e sua veste branca reflete uma aura de luz? E qual o seu nome, irmão?

Se julgam atrasados os espíritos dos pretos e dos índios, devo dizer que amanhã estarei na casa deste aparelho, ${ }^{8}$ para dar início a um culto em que esses pretos e esses índios poderão dar sua mensagem e, assim, cumprir a missão que o Plano Espiritual lhes con-

7 Maiores detalhes sobre este diálogo, ver em Oliveira, (s.d., p.46-48).

8 A expressão refere-se, no vocabulário próprio das religiões mediúnicas, ao médium. No caso Zelio Fernandino de Moraes. 
fiou. Será uma religião que falará aos humildes, simbolizando a igualdade que deve existir entre todos os irmãos e desencarnados. E se querem saber o meu nome, que seja este: Caboclo das Sete Encruzilhadas, porque não haverá caminhos fechados para mim. (Oliveira, p.40)

Como esforço narrativo de instituir uma identidade brasileira para a Umbanda, o mito do Caboclo das Sete Encruzilhadas assume com a fundação ou anúncio da nova religião uma opção claramente voltada para a realidade da maioria da população brasileira. Corrobora sua ligação com os humildes, os desassistidos pelo Estado, a quem, a exemplo do Espiritismo de feição kardecista, privilegiava em seu trabalho assistencial. Porém, ao contrário do Espiritismo, essa narrativa fundante ou anunciadora da Umbanda colocava como protagonistas segmentos despossuídos da hierarquia social, através de uma inversão ritual, capaz de celebrá-los em um Brasil ainda predominantemente rural e acentuadamente desigual. Os antigos donos da terra e os negros, através de uma operação narrativa compensatória, abandonavam sua situação de sujeição e passavam, no panteão umbandista, a figuras cultuais centrais.

O projeto de uma Umbanda colada à nacionalidade brasileira reitera-se em inúmeras publicações e iniciativas, algumas de natureza institucional da religião. Entre os veículos destaca-se a Revista Espiritual de Umbanda, na qual se encontra uma composição imagética extremamente significativa desse projeto. Trata-se de um convite para a "sessão solene para oficialização do 1ㅇ Congresso Nacional de Umbanda”, "9 realizado na Câmara dos Vereadores de São Paulo no dia 17 de agosto de 2013.

Não importam os números dos censos, os adeptos de uma religião explicitamente minoritária aparecem ou formando a

9 Disponível em: <http://terreirosdelimeira.blogspot.com.br/2013/07/apresentacao.html>. Acesso em: 30 set. 2013. 
bandeira nacional ou dela brotando, formando o povo brasileiro. Assim, nessa solução gráfica, a imagem parece buscar a identificação não apenas da Umbanda com a nacionalidade, mas com o povo brasileiro. A imagem, obviamente, como os discursos escritos que remetem a uma identidade, são projetos de atores sociais que não se sujeitam à mera mimese. Particularmente em relação às imagens, os reducionismos e simplificações que veiculam (Paiva, 2002, p.104) são pistas importantíssimas para a compreensão desse projeto de instituição da realidade.

A persistência do projeto identitário da Umbanda como autenticamente brasileira atualiza-se com a força do mito, cujo efeito discursivo acena sempre para a rememoração do 15 de novembro de 1908. Esta data aparece claramente como o projetado instante originário (Chaui, 2000), assumido por algumas lideranças e publicações doutrinárias umbandistas, fiéis ao mito fundador ou anunciador do Caboclo das Sete Encruzilhadas. Em 2008, a Revista Espiritual de Umbanda ${ }^{10}$ dedicava uma "edição histórica" ao considerado "centenário da Umbanda".

Por outro lado, esse projeto nacionalista ganhava ênfase com o endosso, de alguns intelectuais umbandistas, à narrativa de um Brasil predestinado a ser "coração do mundo, pátria do evangelho" (Xavier, 1998). O livro, para os espíritas ditado por Humberto de Campos a Francisco Cândido Xavier, divulgou a representação de uma "história sagrada" para o Brasil, cuja teleologia estava determinada pelos desígnios divinos (Silva, 2005, p.41).

Por outro lado, a leitura espírita da história, com ênfase na ideia de progresso contínuo e com a veemente defesa da república como evidência das conquistas evolutivas humanas, acabou articulando-se à leitura da história do Brasil presente na literatura umbandista do século XX. Alguns marcadores temporais aparecem linearmente encadeados mostrando, por exemplo, a

10 Para um estudo aprofundado desta publicação e sua filiação à tradição do Caboclo das Sete Encruzilhadas, ver Pinheiro (2009). 
relação entre a abolição da escravatura, a proclamação da República e o "nascimento da Umbanda", celebrado justamente a 15 de novembro (Isaia, 1998, 2012).

\section{O Brasil Pentecostal anunciado pelos pioneiros da Assembleia de Deus}

Tal qual o catolicismo e a Umbanda, o pentecostalismo ${ }^{11}$ no Brasil também lançou mão de um mito fundante como recurso narrativo. Mais precisamente vamos nos ater ao mito fundacional da Igreja Evangélica Assembleia de Deus (Iead) e à sua leitura de uma história do Brasil dirigida pela ação do Espírito Santo, capaz de realizar um novo pentecostes em terras brasileiras.

$\mathrm{Na}$ literatura produzida pela Iead, o Brasil surge como um lugar escolhido por Deus para que o chamado avivamento acontecesse de maneira particularmente importante. Segundo essa leitura, a escolha de Deus recaiu, igualmente, nos homens que deveriam iniciar essa obra. No caso, dois suecos, GunnarVingren e Daniel Berg. Oriundos da Igreja Batista, eles haviam emigrado para os Estados Unidos. Na época, Chicago destacava-se como um centro que reunia os que aceitavam os fundamentos do pentecostalismo: o batismo pelo Espírito Santo e a volta de Jesus Cristo

11 O pentecostalismo pode ser resumido como uma leitura da bíblia que enfatiza que como os apóstolos, que receberam o Espírito Santo e passaram a falar em línguas em Pentecostes, os homens de épocas posteriores devem crer na repetição dessa infusão de dons. Dreher (1999) salienta que o pentecostalismo não é homogêneo, tomando configurações históricas e doutrinárias específicas. Por exemplo, a glossolalia (o dom de falar em línguas estranhas) não é considerada consensualmente por todas as denominações pentecostais como prova do batismo pelo Espírito Santo. Aqui estamos usando o termo pentecostal em uma acepção estrita à proposta soteriológica e escatológica da Iead. Há o batismo "nas águas" e o batismo "no Espírito Santo", quando há a experiência ímpar que acompanha os seus dons como a glossolalia, as curas, a interpretação das línguas e o chamado discernimento de espíritos (capacidade de distinguir o Espírito Santo, do espírito humano e dos espíritos malignos, conforme se lê, por exemplo, em Mateus, 12:22-37). 
para buscar a sua igreja (Conde, 2011, p.38). Entre os próprios batistas norte-americanos havia aceitação ao pentecostalismo. E foi justamente em uma convenção das igrejas batistas em Chicago que Gunnar Vingren conheceu a Daniel Berg. Vingren era pastor em South Bend, em Indiana, cerca de $100 \mathrm{~km}$ de Chicago. É nessa cidade que o mito fundante do pentecostalismo assembleiano brasileiro adquire força narrativa. Daniel Berg vai até South Bend visitar o novo amigo Gunnar Vingren. É lá que uma "mensagem profética” acontece, revelando a eles sua missão. Nesta ocasião teriam, pela primeira vez, ouvido uma língua estranha para ambos, a qual, mais tarde constataram ser o português. A mensagem do Espírito Santo era clara: deveriam ir a um lugar desconhecido por eles, chamado Pará. Segundo a narrativa de Vingren:

Entre outras coisas, o Espírito Santo falou através deste irmão [Adolfo Uldin] que eu deveria ir para o Pará. Foi nos revelado também que o povo para quem eu testificaria de Jesus era de um nível social muito simples. Eu deveria ensinar-lhes os primeiros rudimentos da doutrina do Senhor. Naquela ocasião tivemos o imenso privilégio de ouvir através do Espírito Santo a linguagem daquele povo, o idioma português. Ele também nos disse que comeríamos uma comida muito simples, mas que Deus nos daria tudo o que fosse necessário. (Vingren, 2011, p.27)

Para Joanyr Oliveira, a mensagem do Espírito Santo aos dois jovens suecos teria sido transmitida a Adolfo Uldin em um sonho, alguns dias depois de Vingren e Berg conhecerem-se, em 1909:

Alguns dias se passaram até quando um crente batizado no Espírito Santo, chamado Adolfo Uldin, narrou-lhes um sonho, em que os dois amigos eram personagens, e em que lhe aparecera, bem legível, um nome muito estranho: Pará. Uldin jamais lera ou ouvira tal palavra. Mas, entendeu tratar-se de um lugar. (Oliveira, Joanyr 1997, p.34, grifos nossos) 
A narrativa prossegue, reproduzida em muitas publicações da Iead, com os jovens procurando em uma biblioteca onde se localizava a terra “anunciada pelo Espírito Santo”. É assim que, segundo a narrativa fundacional, Vingren e Berg descobrem que, para cumprirem a vontade de Deus, deveriam partir para o norte do Brasil, uma região inóspita e muito diferente dos ambientes a que estavam acostumados. Na região "escolhida por Deus" seriam os anunciadores e instrumentos do Espírito Santo.

É mister que se diga que o norte do Brasil e, particularmente, o Pará estavam longe de serem desconhecidos nos Estados Unidos e nos círculos evangélicos norte-americanos à essa época. A economia da borracha integrara a região ao mercado europeu e norte-americano, sendo o porto de Belém o maior ponto de escoamento da sua produção (Sarges, 2000). Para Pantoja (2012, p.110) a presença protestante na região amazônica era sentida desde meados do século XIX, aparecendo na documentação embates com o clero ultramontano local, notadamente o bispo do Pará, D. Antônio de Macedo Costa. Este defendia a ideia de que a chegada de protestantes à Amazônia encobria "maquinações dos Estados Unidos para tomar o Amazonas" (Pantoja, 2012, p.114). Entre os missionários protestantes atuantes desde o século XIX, Pantoja cita o escocês Richard Holden, que estudara nos Estados Unidos, e que esteve na região no final de 1860. A presença de Holden na Amazônia estaria ligada para Vieira (1980, p.164), a interesses comerciais norte-americanos e europeus a respeito da internacionalização da navegação do Rio Amazonas. Uma outra evidência que precisa ser citada para contextualizarmos a mensagem fundante da AD no Brasil diz respeito à presença anterior de um missionário batista, de origem sueca em Belém, quando da chegada de Gunnar Vingren e Daniel Berg. É o caso do pastor batista Eurico (ou Erik) Nelson, batizado primeiramente na Igreja Luterana sueca e mais tarde rebatizado na Igreja Batista (Ribeiro, 2011, p.28-29). Em uma narrativa contrária ao pentecostalismo, Nelson aparece como 
acolhendo, no porão da igreja, Gunnar Vingren e Daniel Berg, nos primeiros tempos no Brasil (O Bereano, 2002). O interessante nas memórias, tanto de Gunnar Vingren, quanto de Daniel Berg é que a nacionalidade de Nelson é omitida. Naquelas fontes, os missionários suecos escrevem que, chegando a Belém, encontraram logo no primeiro dia, ainda no modesto hotel onde se hospedaram um jornal, em cujo expediente Vingren identificou o nome de um pastor metodista que conhecera nos Estados Unidos. "Aqui está Daniel - disse ele - Sem dúvida é a resposta de Deus mostrando-nos o caminho aberto" (Berg, 2011, p.48; Conde, 2011, p.33). Foi este pastor metodista que os levou até ao pastor batista. Logicamente que devemos compreender esses relatos, com suas omissões, silêncios e possíveis fabulações, a partir do esforço em instituir e reforçar uma determinada identidade que seja socialmente reconhecida. Neste sentido, Bourdieu (2013) mostra que esses relatos são marcados pela lógica da alocução. Ou seja, são relatos proferidos a partir de um determinado lugar social, no qual o indivíduo constrói "um conjunto de atributos e de atribuições que permitam sua intervenção como agente eficiente nos diferentes campos" (Bordieu, 2013, p.82). Desta maneira torna-se compreensível a seleção de informações que orientam essas narrativas. Assim ganha consistência a narrativa mítica, dos enviados por Deus ao Brasil a fim de possibilitar um novo Pentecostes. Ganha consistência, por outro lado, a narrativa de um lugar originário, escolhido por Deus (Pará) a fim de que suas promessas e seus dons fossem espalhados pelo Brasil. Promessas e dons atualizados cotidianamente no presente e "atestados" desde a madrugada de 8 de junho de 1911, quando Celina Albuquerque tornou-se a primeira brasileira batizada com Espírito Santo. ${ }^{12}$

12 O primeiro batismo no Espírito Santo em terras brasileiras, de Celina Albuquerque, acontecido em 8 de junho de 1911 aparece como um importante marcador narrativo nas obras oficiais da Iead. 
As fontes assembleianas reiteram a narrativa mítica, segundo a qual os instrumentos de Deus lançaram as sementes da principal denominação pentecostal do Brasil. ${ }^{13}$ Por outro lado, o Brasil é visto no discurso pentecostal como o lugar do mundo em que, de maneira ímpar a mensagem que "Jesus salva, cura, batiza com o Espírito Santo e em breve voltará”, instalou-se e desenvolveu-se "como em nenhuma parte da terra" (Manifesto, 2010). Fica evidente o propósito da Iead mostrar-se como a vanguarda pentecostal do Brasil, já que "Deus nos constituiu como cabeça e não como cauda". ${ }^{14}$

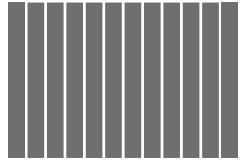

12,3 milhões Assembleia de Deus

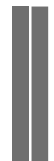

2,2 milhões

Congregação Cristã do Brasil

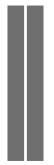

1,9 milhão Universal do

Reino de Deus

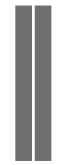

1,8 milhão

Evangelho

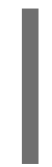

845 mil Deus é amor

Gráfico 3: As principais igrejas evangélicas pentecostais, segundo o Censo de 2010 do IBGE

Fonte: Censo do IBGE (2010).

A principal denominação pentecostal no país plasmou uma leitura da história do Brasil funcional ao seu esforço identitário. Precisava mostrar o seu caráter diferencial frente a um Brasil, que, pelo menos nos primórdios de sua atuação no Norte, ainda apresentava um catolicismo imbatível. A leitura da história que os documentos produzidos pela lead vão trazer é parte constitutiva deste esforço. Emblemática é a Introdução ao livro de Emílio Conde (Conde, 2011) escrita por Claudionor Corrêa de Almeida. Nesta Introdução o autor deixa clara a intenção de imprimir

13 Rechaçados da Igreja Batista em Belém, cujo pastor não aceitava o pentecostalismo, Vingren e Berg fundam a Missão da Fé Apostólica, primeiro nome da futura Igreja Evangélica Assembleia de Deus.

14 Palavras do Pastor José Wellington Bezerra da Costa, Presidente da Convenção Geral das Assembleias de Deus no Brasil (Araujo, 2011, p.V). 
um sentido, capaz de tornar compreensível a atuação da AD no Brasil; sentido este, obviamente, aliado aos planos divinos. Evidencia o predomínio histórico do catolicismo como obstáculo à propagação do evangelho, critica o descaso dos reformadores à época de Lutero e Calvino em pregarem a palavra de Deus no Brasil e apresenta Berg e Vingren como os introdutores do pentecostalismo em terras brasileiras (silenciando completamente em relação à anterior vinda de Louis Francescon fundador da Congregação Cristã do Brasil, denominação, igualmente, pentecostal). Berg e Vingren aparecem como os representantes de um dos "maiores fenômenos religiosos das últimas eras" (Conde, 2011, p.21).

A narrativa de Conde insere-se totalmente em uma visão intra institutionis, assumindo um projeto no qual os fatos humanos e as promessas escatológicas encadeiam-se, dando sentido à projetada nomeação da $\mathrm{AD}$ como realidade visível do plano divino de evangelizar o Brasil e despertar sua vocação missionária. ${ }^{15}$ A todo o momento a narrativa mostra a atuação divina governando, através de profecias e revelações, os rumos, tanto individuais dos seus líderes, quanto da própria igreja.

$O$ peso institucional da obra de Conde no projeto de afirmação da identidade assembleiana no Brasil pode ser aferido na simbologia do próprio logotipodo centenário da AD. ${ }^{16} \mathrm{Nela}$ vemos que o número 1 aparece como uma grande labareda representando o fogo do Espírito Santo. ${ }^{17}$ Esta representação apa-

15 Neste sentido, a AD já nos seus primórdios no Brasil lançou-se à expansão missionária, já em 1913, com o embarque de José Plácido da Costa para Portugal, a fim de evangelizar aquele país (Conde, 2011, p.45).

16 Disponível em: <http://files.celmoalmeida.com/200000751-b642fb73ce/ centenario.jpg >. Acesso em: 1 jul. 2013.

17 Na descrição do logotipo feita por Araujo (2011, p.537) os dois zeros aparecem como duas alianças entrelaçadas representando "o compromisso e a fidelidade que a AD vem tendo com a obra de Deus ao longo de um século no Brasil”. A primeira aliança aparece com as cores da bandeira da Suécia e a segunda com as cores da bandeira brasileira. 
rece em Araujo, ligada às expressões "tochas da fogueira [forma como o livro de Conde menciona os missionários Daniel Berg e Gunnar Vingren] e 'chama pentecostal”" (Araujo, 2011, p.537).

Duas características marcantes que compõem a narrativa de Conde sobre Vingren e Berg são a eleição e o sacrifício. Conde construiu, assim, uma narrativa extremamente familiar ao martírio cristão, capaz de habilitar os fundadores ao desfrute das atribuições necessárias ao reconhecimento social. Desta forma, tendo a protegê-los o "Deus de Abraão" (Conde, 2011, p.30), Vingren e Berg, como na narrativa evangélica das tentações de Cristo no deserto, tiveram que enfrentar todo o tipo de investidas do demônio, a fim de demovê-los da sua missão. A começar pelas primeiras impressões de uma terra onde a pobreza era crônica, o meio geográfico extremamente hostil, onde proliferavam as doenças e os perigos, tanto dos humanos incrédulos e refratários à palavra de Deus, quanto dos animais ferozes na floresta. Na narrativa da chegada de Vingren e Berg a Belém feita por Conde, o próprio aspecto horripilante de uma cidade invadida pela lepra aparece como sintoma da ação diabólica tentando demover os emissários de Deus:18

Não foi fácil imaginar quais foram as primeiras impressões dos jovens missionários naquela tarde em uma praça de Belém, sentindo o sol a aquecer-lhes as roupas grossas e pesadas. Naquela época, Belém não possuía muitas atrações. Além disso, fora invadida por multidões de leprosos vindos até de nações limítrofes com o Amazonas, atraídos pela notícia da descoberta de uma erva que, diziam, curava a terrível doença. A pobreza do povo também contrastava

18 A descrição de uma cidade invadida pela lepra e os perigos que rondavam quem se atrevesse a andar no meio daquela população aparece nas memórias de Berg. É o mesmo Berg quem registra: "O fato de continuarmos fortes, com saúde e dispostos a pregar o evangelho ali em condições tão precárias, era visto como prova de que Deus nos havia enviado” (Berg, 2011, p.56). 
com o padrão de vida da outra América. O diabo aproveitou-se de tudo isso para desanimar os recém-chegados. Estes, contudo, tinham vindo por ordem do Rei dos reis: nada os amedrontaria nem os faria recuar. (Conde, 2011, p.30)

Vencendo os inimigos naturais (o meio, o clima, os animais ferozes), estabelecendo um poder que vinha diretamente de Deus sobre os que ignoravam ou negavam os fundamentos do pentecostalismo e, sobretudo, triunfando sobre as armadilhas e tentações demoníacas, Gunnar Vingren e Daniel Berg aparecem nas narrativas oficiais da Iead como instrumentos divinos, concretizando o seu plano de tornar conhecida a sua palavra e suas promessas no Brasil. Através desses recursos discursivos a documentação oficial da Iead tenta atualizar rememorativamente o mito de fundação, impondo-se como narrativa autorizada de um passado sempre presente.

\section{Concluindo}

Trabalhamos até aqui com três narrativas míticas, cujo efeito buscado acenava na direção da qualificação da religião, na construção identitária e na sua aproximação com a história nacional. A Igreja Católica, a Umbanda e a Igreja Evangélica Assembleia de Deus recorreram a um esforço mítico capaz de mostrar sua especificidade frente ao "mercado de salvação" em curso no Brasil da primeira metade do século XX. Esforçaram-se, assim, por salientar uma mensagem soteriológica peculiar, legítima e necessária à vida nacional. Por isso vamos encontrar três narrativas nas quais esses componentes do campo religioso brasileiro vão esforçar-se por tornar evidente a superioridade dos bens simbólicos que colocavam à disposição da sociedade. Nos três casos buscava-se oferecer uma narrativa plena de valores reco- 
nhecidos socialmente. Nem seria de outra forma, já que esses discursos almejavam a sempre atribuída, reconhecida e nunca autoenunciada ${ }^{19}$ legitimidade social. Como opção religiosa majoritária e mais próxima do poder, o catolicismo vai apelar discursivamente para a construção de sua presença no "início" da nação e do Estado, ${ }^{20}$ construindo a antirrealidade não católica. Já para umbandistas e assembleianos, a narrativa mítica de sua história vai ter que apelar para um passado muito mais próximo, mas, igualmente capaz de reforçar a especificidade de seus bens de salvação. O "anúncio" ou "fundação" da Umbanda pelo Caboclo das Sete Encruzilhadas e o "cumprimento" da profecia pentecostal assembleiana no Brasil apelavam para uma mensagem nova. Os desígnios divinos e sua ação providencial na história atualizavam-se no século XX, apontando para bens simbólicos que deveriam superar os da religião majoritária. De um lado, o "anúncio" do Caboclo das Sete Encruzilhadas, traria, finalmente, uma religião capaz de consorciar e celebrar a "alma nacional"; de outro, o "cumprimento" da profecia pentecostal no Pará traria para o Brasil a promessa cristã existente em Atos dos Apóstolos: o batismo com o Espírito Santo. Partindo da ideia enunciada por Halbwachs (1952, p.296), segundo a qual a sociedade é essencialmente uma memória, podemos concluir pensando que o discurso católico, o umbandista e o assembleiano mostravam-se como esforços em lembrar, tornando presente rememorativamente um passado mítico. Por outro lado, voltando à nossa ideia inicial, esse esforço mnemônico, claramen-

19 Ver neste sentido as relações entre o exercício das formas de dominação e sua relação com a legitimidade em Max Weber. Para Weber todas as formas de dominação procuram "despertar e cultivar a crença em sua 'legitimidade", (Weber, 2009, v.1, p.139).

20 A já citada Carta Pastoral Coletiva de 1922 avança claramente neste sentido. Até mesmo porque escrita para louvar a "importância" e a "presença" católica na emancipação política, cujo centenário comemorava-se. 
te acenou para um projeto, no qual católicos, umbandistas e assembleianos, a um só tempo, tentaram instituir identidades e pensar a sua e a nossa história. Alguns marcos temporais representaram, nesse esforço instituidor de identidades, momentos especialíssimos. Isto aconteceu nas comemorações dos três centenários: da independência política em 1922, da "fundação" ou "anúncio" da Umbanda em 1998 e da instituição do pentecostalismo assembleiano em 2011, que funcionaram como momentos de reforços tanto das respectivas identidades quanto dos vínculos entre o presente e um passado mítico que precisava ser avivado e lembrado. 


\title{
Os novos intérpretes e a velha questão: o que é o Brasil?
}

\author{
Karina Anhezini ${ }^{1}$ \\ Ricardo Alexandre Ferreira ${ }^{2}$
}

Pensar em identidade nacional em meio aos preparativos da Copa do Mundo de Futebol e, ao mesmo tempo, imersos em protestos que eclodem nas principais cidades e se espraiam pelos quatro cantos do país é, no mínimo, inspirador. Inspirador e inquietante, pois vemos emergir por todas as partes usos do passado e definições de enunciados que se querem históricos e que se valem da história para a criação de solidariedades em meio às já chamadas "jornadas de junho". Vemos, com certa recorrência, centenas de pessoas se unindo por motivações distintas e evocando, frequentemente, por meio da ostentação de símbolos nacionais, a noção de identidade, tão cara aos brasileiros, mas que parecia desgastada desde as comemorações dos 500 anos.

1 Professora do Departamento de História da Universidade Estadual Paulista "Júlio de Mesquita Filho" (Unesp), câmpus de Assis, autora de Um metódico à brasileira: a História da historiografia de Afonso de Taunay (2011). E-mail: kanhezini@gmail.com.

2 Professor do Departamento de História da Universidade Estadual Paulista "Júlio de Mesquita Filho" (Unesp), câmpus de Franca. É autor de Três vezes Zumbi: a construção de um herói brasileiro (2012). 
Embora seja tentador fazê-lo aqui, o presente ensaio não tratará de tais eventos, pelo menos não enfrentará diretamente o desafio de interpretá-los ainda no calor de seus desdobramentos, outros colegas, mais audazes que nós, já iniciaram tal esforço. ${ }^{3}$ Bem mais modesto em suas intenções, o presente texto se encarrega de uma tarefa não menos árdua e, a nosso ver, indispensável para a reflexão historiográfica contemporânea. Pretendemos mapear como historiadores e outros intelectuais da seara das Ciências Humanas e Sociais têm refletido a respeito do tema identidade do Brasil e dos brasileiros, na primeira década do século XXI.

O trabalho de escolha das obras mais representativas dos principais modos de interpretar e construir nossa noção de identidade, na primeira década deste século, levou em conta o desejo de mapear padrões. Padrões estes reveladores de que a identidade ainda é uma concepção tida como válida no debate contemporâneo realizado pelos estudiosos das Ciências Humanas. Como o tema vem sendo tratado é a questão que pretendemos colocar em primeiro plano neste ensaio. Por certo, o leitor não encontrará novas definições de identidade ou caminhos inovadores para a "formação" das solidariedades nacionais. O que encontrará são duas maneiras escolhidas pelos autores brasileiros contemporâneos para tratarem do tema.

A primeira, muito frequente na academia ultimamente, incide sobre as diversas coletâneas dedicadas a reunir intelectuais que se propõem a refletir sobre os caminhos que o Brasil tem tomado diante dos desafios contemporâneos a partir das soluções dadas pelos seus mais conhecidos e, poderíamos dizer, tradicionais intérpretes. A outra recai sobre as modificações sofridas pela interpretação de um mesmo intérprete. Na segunda e última

3 Fazemos referência às análises dos autores: Schwartz (2013) e Žižek (2013), ambos publicados e disponíveis em: <http://blogdaboitempo.com.br>. O blog da Editora Boitempo publicou em 2013 Cidades rebeldes: passe livre e as manifestações que tomaram as ruas do Brasil. 
parte do texto, procuramos compreender os caminhos que a reflexão sobre o ser brasileiro têm tomado nos últimos anos a partir das mudanças de visada sobre a mais importante obra de um dos grandes intérpretes da construção do Brasil: Gilberto Freyre.

\section{No limiar do século: coletâneas de intérpretes e interpretações}

No final do século XX, parece ter surgido uma necessidade nova de revisão/avaliação da identidade nacional. Em meio aos preparativos para as comemorações dos 500 anos do descobrimento do Brasil historiadores, jornalistas, críticos literários, filósofos, sociólogos, dentre muitos outros estudiosos brasileiros, se viram tentados ou motivados a compor obras que pudessem apresentar ao público especializado e, também aos menos afeitos a esse tipo de leitura, uma resposta à pergunta: o que é o Brasil? A evocação da data comemorativa levou à organização de sentidos a respeito do Brasil, como principal estratégia para a produção de coletâneas de intérpretes e interpretações que versassem sobre esse território, povo, cultura, nação. Não muito longe dessa inquietação estavam as editoras ${ }^{4}$ e o poder público, ${ }^{5}$ interessados em financiar, produzir e publicar esses "monumentos da cultura nacional" em vários e alentados volumes como parte das comemorações.

Na tentativa de mapear essas construções de Brasil, a seleção aqui realizada partirá de dois empreendimentos editoriais: Viagem incompleta (2 volumes) e Introdução ao Brasil (2 volumes). Outras

4 É ilustrativo desse interesse a Coleção Retratos do Brasil da Editora Companhia das Letras: <http://www.companhiadasletras.com.br/busca. php?b_categoria $=008 \&$ b_filtro=livro $>$.

5 Refiro-me aqui especificamente aos três volumes coordenados por Silviano Santiago, Intérpretes do Brasil, e patrocinado pelo Ministério das Relações Exteriores. 
coletâneas ${ }^{6}$ da mesma natureza poderiam integrar esse rol, no entanto consideramos que as duas selecionadas podem delinear os contornos da Identidade do Brasil para o século XXI; das eleitas tomamos preferencialmente, mas não somente, as introduções que ocupam o lugar dos prefácios, como "pontos de observação" por meio dos quais se intenta apreender certo projeto historiográfico para o tratamento da temática da identidade. Como bem lembrou François Hartog, "esses observatórios têm evidentemente muitos limites: seus ângulos mortos e seu ponto cego" (Hartog, 2001, p.10). Corremos o risco aqui das simplificações pela "distância entre o que se diz que se quer fazer e o que se fez efetivamente" e no caso das coletâneas, entre o projeto do organizador e a efetiva realização dependente de tantos outros autores. Contudo, o que privilegiamos foi a descrição desses projetos.

\section{A incompletude da viagem totalizante}

Figurou dentre os lançamentos divulgados pela Folha de S.Paulo ${ }^{7}$ em abril de 2000 a obra Viagem incompleta. Foi anunciada na segunda-feira, 24 de abril, como obra que "repensa os 500 anos" a partir de "um balanço de como o país foi pensado nesses 500 anos". A ênfase da divulgação que recai sobre esse "pensar o Brasil" se deve à primeira linha da introdução da obra: "Ideias de Brasil, eis a temática geral da obra que o leitor tem sob seus olhos", seguida de uma explicação, "trata-se, aqui de indagar, ao longo dos estudos e ensaios elaborados por especialistas convidados, dos sentidos da história do processo civilizador no Brasil” (Mota, 2000a, p.13).

6 Cf. Rocha (2003); Axt; Schüler (2011); Schwarcz; Botelho (2009); Reis (2000, 2006).

7 “Viagem incompleta" repensa os 500 anos. Folha de S.Paulo, 24 abr. 2000. Disponível em: <http://www1.folha.uol.com.br/fsp/acontece/ac2404200002. htm>. Acesso em: 1 jul. 2013. 
Antes mesmo da introdução, somos convidados a ler o livro por duas notas, uma do editor, diretor regional do Senac de São Paulo, e outra do coeditor, diretor regional do Sesc de São Paulo que carregam a mesma máxima: "é impossível pensar o futuro sem conhecer o passado" (Mota, 2000a, p.6). Utilizando-se de outro lugar comum da cultura ocidental, a viagem (Hartog, 2004), a obra reúne renomados pesquisadores, viajantes que recortaram tempos e perspectivas distintas e que, apesar disso, anunciam a incompletude de uma viagem que tem início muito antes da era dos descobrimentos. Mesmo estampando na capa dos dois volumes que compõem a obra, em alto relevo, o recorte temporal 1500-2000 o primeiro capítulo remonta a priscas eras com uma viagem até a pré-história da América. A opção por iniciar a narrativa da História do Brasil antes de 1500 não é nova, podemos destacar, com o intuito de não nos alongarmos muito nessa questão, o marco historiográfico que significou, em 1907, a publicação do primeiro capítulo intitulado "Antecedentes indígenas” dos Capítulos de história colonial de João Capistrano de Abreu (1853-1927) (Abreu, 2000).

O responsável por guiar essa viagem é o historiador Carlos Guilherme Mota. Professor titular de História Contemporânea da Faculdade de Filosofia, Letras e Ciências Humanas da Universidade de São Paulo, Mota tornou-se conhecido pela tese de livre-docência defendida em 1975 e publicada dois anos depois, Ideologia da cultura brasileira (1933-1974). Quem nos apresenta uma análise dessa obra é Manoel Luis Salgado Guimarães:

Profundamente marcado pelos debates em torno da cultura brasileira e de sua dependência/autonomia, o trabalho de Carlos Guilherme Mota procura interrogar as produções das quatro décadas a partir dos anos 30 do século XX, segundo o "conceito de ideologia", supondo as íntimas relações entre esta produção e ideologias políticas articuladas a interesses sociais. Em cada uma das cinco etapas propostas em seu trabalho (A. Redescobrimento do Brasil. 
B. Primeiros frutos da Universidade. C. Era de ampliação e revisão reformista. D. Revisões radicais. E. Impasses da dependência). Carlos Guilherme procede à apresentação dos autores fundamentais e seus textos segundo a chave de leitura proposta [o marxismo de Gramsci]. (Guimarães, 2005, p.39-40)

As marcas dos antagonismos entre centro e periferia, dependência e autonomia, preocupações desse texto da década de 1970, permanecem nessa Viagem incompleta que quer "escapar dos modismos da pós-modernidade periférica e do convencionalismo" por meio de uma investigação minuciosa em busca dos significados da formação do Brasil e da existência do povo brasileiro. São cinco séculos daquilo que Mota denominou "experiência brasileira", um processo longo, inacabado, avaliado pelo autor como incompleto sob a justificativa de que muito ou quase tudo ainda estava por se fazer na Terra brasilis no limiar do século XXI.

Para responder à questão da identidade no Brasil e traçar esse diagnóstico, o autor organizou dois volumes com estudos de autores reconhecidos da intelectualidade brasileira. Não se trata de uma obra a respeito dos intérpretes do Brasil, ao contrário, são períodos e temáticas esquadrinhadas por estudiosos contemporâneos. Mota apresenta os escolhidos do primeiro volume:

No arco do tempo, percorre-se [no] primeiro volume desde as experiências da Nova Lusitânia, revisitada superiormente por Evaldo Cabral de Mello, até a constituição, já no fim do século XIX, de um "Brasil mestiço", sob a lente da crítica de Roberto Ventura. No percurso de quatro séculos, examinam-se os diversos conceitos de "povo", de colonização e descolonização, resistência negra, de identidade, na interpretação dos escritos críticos de Stuart B. Schwartz, István Jancsó e João Paulo Pimenta, de Kenneth Maxwell, Carlos Guilherme Mota, João José Reis, Karen M. Lisboa, Francisco Alambert (Mota, 2000, p.21). 
Esse traçado começa com o estudo de Aziz Nacib Ab'Saber, ausente da descrição citada acima, e remonta à "gênese" não somente da formação nacional, mas dos primeiros vestígios da vida humana no território que seria o Brasil sugerindo, na opinião de Carlos Guilherme Mota, "uma revitalização e ampliação notável dos estudos históricos, em busca da especificidade de nossa formação” (Mota, 2000, p.15).

Há o intuito declarado de se evitar o tema das origens, e em seu lugar, a partir de um estudo de longa duração, proporcionar aos leitores dois novos volumes de uma História do Brasil. Se esta não é mais possível de ser composta pela mão de um único autor, como no tempo de Francisco Adolfo de Varnhagen, ela ainda poderia ser escrita numa coletânea bem orientada para os temas e contextos que definem a nacionalidade.

Entretanto, o autor salienta que mesmo tendo esse recorte alongado, fundamental para a compreensão do processo, nossa identidade coletiva - o tema central - foi delineada na época da Independência, período para o qual o autor retoma a clássica caracterização de Caio Prado Júnior, ou seja, a Independência entendida como "Revolução". Com isso, afirma uma posição historiográfica e uma História do Brasil com poucas rupturas e marcada, consequentemente, por continuidades. Esclarece que, apesar de apresentar um recorte de mais de cinco séculos, a coletânea representa uma oposição à ideia, qualificada de equivocada, de História do Brasil Colonial. "A história do Brasil propriamente, na perspectiva do organizador, somente se afirmaria no período da Independência” (Mota, 2000, p.16).

Isto se dá porque as idas e vindas de "ideias de Brasil”, narradas nos estudos que compõem a coletânea, resultam no diagnóstico da coexistência de "dois Brasis" no início do novo milênio. A partir de uma citação de Karl Marx, que percebeu para outra época e contexto a convivência de "estamentos pretéritos com classes futuras", Mota explica que "numa região do planeta em 
que vários passados irresolvidos ainda se fazem presentes” e os estudos demonstram "a atuação de filhos de remanescências coloniais, inquisitoriais, filipinas, joaninas, imperiais, patriarcais e outras" (Mota, 2000, p.16) a rota da viagem promete ser longa.

Quando voltamos o olhar para a introdução do volume 2 da coletânea, dedicada ao século XX, período caracterizado como “a grande transação”, essa incompletude se realiza nas histórias a respeito de uma identidade político-cultural e político-institucional em análises dos intérpretes do Brasil, da literatura, do Estado, do direito, da política interna e externa e do planejamento urbano. Grande destaque é dado à experiência cultural miscigenada que gerou interpretações inéditas e indeléveis no pensamento social e político do Brasil no século XX. O que justifica essa retomada das grandes interpretações, esse olhar para os temas do passado na busca de um elo com o futuro.

O que parece, de fato, informar o itinerário a ser percorrido para a viagem apresentada é a percepção de uma crise. "O momento atual", limiar do século XXI, é descrito como "fim de ciclo", "fim da história", "fim das ideologias" e ao mesmo tempo de "florescimento de novas frentes historiográficas" (Mota, 2000, p.21) que permitem perceber "uma renovada consciência histórica" a despontar com ambiguidades, "mas também com nada desprezíveis aspectos positivos, de resistência e criatividade empenhadas" (Mota, 2000a, p.14). Assim, a narrativa dessa incompletude construída em tempos de crise sinaliza suas pretensões totalizantes como capazes de orientar as viagens do novo século. O lugar que se quer ocupar com a coletânea no conjunto das histórias produzidas a respeito do Brasil é a de ponte para o futuro.

\section{Um banquete de mangas e cajus: apenas uma entrada}

Assim como a coletânea apresentada anteriormente, Introdução ao Brasil: um banquete no trópico também foi publicada 
pela Editora Senac de São Paulo como parte das comemorações dos "nossos 500 anos". O Brasil, como explica a nota do editor, é o tema que será servido aos leitores sem a pretensão de "colocar o ponto final no assunto, pois se trata de uma introdução" o que se pretende, portanto, "é estimular o contato direto com os textos originais. Alcançado esse objetivo, a Editora Senac São Paulo já terá cumprido o seu papel, dilatando os horizontes de conhecimento da nossa realidade" (Mota, 2004, p.7).

As capas dos dois volumes lançados separadamente, o primeiro em 1999 e o segundo em 2000, convidam o leitor a se deliciar nesse banquete a respeito do Brasil com as ilustrações de mangas e cajus. Essas frutas que também ocupam um lugar privilegiado nas descrições de viagem interpretadas por Sérgio Buarque de Holanda em Visão do Paraíso, são os primeiros atrativos da obra organizada pelo jornalista Lourenço Dantas Mota.

O espírito que inspirou o projeto editorial, apresentado por Lourenço Dantas Mota nas introduções, foi definido desde as primeiras linhas. O organizador declara ter entregue aos professores e intelectuais reunidos na coletânea a tarefa de ensinar não no sentido de transmitir um conhecimento, mas de "atiçar a curiosidade, provocar a imaginação e estimular voos mais altos" (Mota, 2004, p.11). Estabelece-se com isso a pergunta: como atiçar a curiosidade dos leitores? A resposta fica mais difícil ainda quando pensamos no amplo público leitor esperado pelo organizador: todos os interessados em compreender o Brasil, de estudantes a "leigos ilustrados" passando por professores que, caso não aprendam muito com a obra, possam, ao menos, utilizá-la para estimular seus alunos.

A escolha para o sucesso desse intento foi certeira. Em vez de agregar interpretações a respeito de uma seleção de temas sobre o Brasil, Introdução... reúne intérpretes apresentados por meio de resenhas. Mais certeira ainda foi a condução desse trabalho que carrega a definição clara de que resenhas "são um 
convite e uma útil introdução à leitura, não são a leitura" (Mota, 2004, p.22).

Não se trata de expor ou discutir, por exemplo, o pensamento de Gilberto Freyre ou Sérgio Buarque de Holanda, o que exigiria a consideração do conjunto de suas obras, e portanto estudos mais extensos e minuciosos, mas mostrar o que é Casa-grande É senzala e o que é Raízes do Brasil - sua estrutura, principais temas tratados e teses defendidas. (Mota, 2004, p.11)

Além de apresentar um conjunto composto por 36 obras de vários autores, a reunião coordenada por Lourenço Dantas Mota tem a intenção de oferecer aos leitores um banquete "no sentido do diálogo platônico de mesmo nome" (Mota, 2004, p.12). Essa inspiração quer reunir personagens distintos num encontro que, em certa medida, apague o tempo e coloque lado a lado Os Sermões de padre Antônio Vieira e Darcy Ribeiro com a obra Os índios e a civilização, de 1970.

É claro, cabe aqui destacar, que os autores escolhidos para resenhar as obras apresentam suas interpretações dos livros selecionados. As resenhas não são, e nem se espera que fossem, apresentações imparciais das obras. O que o organizador insiste em destacar na introdução é que a respeito do tema da coletânea, ou seja, o Brasil, o leitor saia da leitura do livro com a sensação do diálogo entre as diversas interpretações produzidas a seu respeito. Diálogo por vezes devedor de interpretações anteriores ou, no sentido contrário, antecipador de argumentos importantes que seriam desenvolvidos em outros tempos. $\mathrm{Ou}$, mais do que essa relação temporal simples entre o antes e o depois, um diálogo que simplesmente desperte no leitor o interesse pelos autores do menu.

As introduções dos volumes apresentam o cardápio buscando dar sentido aos diálogos dados a ler pelas resenhas. Ao 
apresentar os volumes, Mota segue a ordem dos sumários dos livros e utiliza a estratégia do tecelão que escolhe alguns fios e vai tecendo, de forma habilidosa, os argumentos destacados pelos resenhistas.

Foram selecionados para o primeiro volume os seguintes autores: Padre Antônio Vieira, André João Antonil, José Bonifácio, Visconde de Mauá, Joaquim Nabuco, Eduardo Prado, Euclides da Cunha, Capistrano de Abreu, Paulo Prado, Gilberto Freyre, Sérgio Buarque de Holanda, Caio Prado Júnior, Victor Nunes Leal, Oliveira Vianna, Celso Furtado, Raymundo Faoro, Antonio Candido, José Honório Rodrigues e Florestan Fernandes.

Com eles, o organizador costurou um texto que busca mostrar "como nos vimos e nos julgamos ao longo da história". A partir do conjunto formado por uma obra significativa de cada um desses autores, Lourenço Dantas Mota declara ter conseguido levantar "as grandes perguntas que nos fizemos - e as várias respostas que lhe demos - sobre o que somos e qual o nosso lugar no mundo, sobre os obstáculos que entravam ou retardam nossa marcha e o que fazer para removê-los" (Mota, 2004, p.21).

Caso a apresentação do primeiro volume terminasse aqui teríamos mais uma tentativa de compor uma totalidade das interpretações de Brasil, senão realizada por meio de estudos contemporâneos de alguns temas, exposta por meio da escolha de 19 obras de autores eleitos como significativos pelo cânon literário e historiográfico.

Ao virar a página, entretanto, a assertiva de que as principais perguntas e respostas a respeito do Brasil estavam comtempladas naquele primeiro volume, que por um momento perdeu o tom de Introdução e assumiu o de conclusão, se esmorece e abre espaço para as lacunas.

Se o objetivo da obra é "estimular o contato com os textos originais e facilitar o acesso dos não especialistas ao diálogo desses autores" (Mota, 2002, p.24), os resenhistas apontaram, 
no primeiro volume, que algumas obras carecem de outros autores para o diálogo e de outras obras dos mesmos autores para a completa inteligibilidade daquelas já contempladas. É o caso de três que ganharam espaço para mais uma de suas obras. Sérgio Buarque de Holanda, que já figurava no primeiro volume com Raízes do Brasil, foi escolhido para abrir o segundo volume com Visão do Paraíso, Florestan Fernandes com A integração do negro na sociedade de classes - A revolução burguesa no Brasil foi a escolha do primeiro volume - e Oliveira Vianna apresentado a partir de Instituições políticas brasileiras ganhou uma resenha de Populações meridionais do Brasil no segundo volume.

A introdução ao Brasil se amplia drasticamente nesse último livro, pois não somente outras obras dos mesmos autores entram no banquete, mas outros autores são convidados para o diálogo: História geral do Brasil de Francisco Adolfo de Varnhagen, História geral das bandeiras paulistas de Afonso d'Escragnolle Taunay, Vida e morte do bandeirante de Alcântara Machado e D. João VI no Brasil de Oliveira Lima.

O diálogo se torna mais complexo e acrescenta temáticas fundamentais para a compreensão do Brasil quando se acrescenta o pai da história nacional oitocentista ao lado de autores que muitas vezes são deixados em segundo plano no rol de intérpretes do Brasil. Aliás, cabe destacar aqui que Taunay e Alcântara Machado ainda hoje não figuram frequentemente nesse tipo de inventário. Lourenço Dantas Mota, contudo, destaca no início da introdução ao segundo volume que sem eles os temas da expansão territorial e do bandeirismo não estariam contemplados nessa narrativa de Brasil. Além do diálogo entre os autores escolhidos, é importante salientar que o trabalho monumental de Taunay cujo resultado são os 11 volumes publicados entre 1924 e 1950, a História geral das bandeiras paulistas, carrega o mérito de ter conseguido reunir os argumentos e, mais do que em qualquer outra obra por ele escrita, os elementos que encaminhados 
provavam, em sua opinião e de muitos de seus contemporâneos, a tese de que São Paulo foi o centro irradiador dos "bravos" sertanistas que desbravaram o Brasil, transformando uma pequena extensão de terra em uma nação quase continental. Para conseguir levar a cabo tal feito, Taunay precisou dialogar com a produção a respeito do mesmo tema que se avolumava dia a dia. Assim, pelas páginas da História geral desfilaram os argumentos dos principais autores do período em que a obra foi produzida. Na busca pela verdade moderna, Taunay agrupou os "erros" e os "acertos" dos mais diversos autores, apresentando extensos balanços bibliográficos da produção do período. Dessa forma, ao introduzir, especialmente, Taunay e Alcântara Machado, Lourenço Mota estabeleceu o diálogo com a obra de diversos autores que não integram a coletânea e com Capistrano de Abreu resenhado no primeiro volume.

No entanto, nesse diálogo que integra nomes não canônicos ao lado dos cânones dos intérpretes do Brasil, dois autores são servidos como prato principal, tendo suas trilogias resenhadas: Joaquim Nabuco com Um estadista no Império, O abolicionismo e Minha formação e Gilberto Freyre com Casa-grande E senzala, Sobrados e mucambos, e Ordem e progresso. Como o autor destaca, o "peso da escravidão" impregnou a sociedade brasileira e essas obras perpassam nossa formação social, política e cultural com as ambiguidades da identidade ora europeia, ora brasileira, ora africana. Afirmava-se ali, naquelas obras, a importância da nossa formação racial como ingrediente fundamental da constituição histórica do país e de seu povo. Freyre, como veremos mais adiante, na segunda parte deste ensaio, acabou por se tornar o mais discutido representante do cânon sobre a formação do Brasil.

As escolhas para a Introdução ao Brasil... apontam para uma nação múltipla com várias linhas de força e, apesar de, nos textos introdutórios, o organizador traçar uma narrativa coerente ao 
costurar as resenhas, ainda permanece um diálogo que busca oferecer ao leitor diversas interpretações, muitas delas conflitantes, como seria de se esperar, a respeito do que o Brasil é. De fato, a escolha por apresentar os intérpretes possibilita uma visão complexa e introdutória que tem a intenção de se completar somente com o saborear de cada obra ali oferecida para a leitura integral.

\section{Das coletâneas dos 500 anos aos estudos sobre um grande intérprete do Brasil: Gilberto Freyre}

Empenhados no desafio de diagnosticar como a intelectualidade brasileira tem se dedicado ao estudo das identidades, escolhemos lançar uma visada mais detida em uma obra que se impôs como parada obrigatória nessa viagem, sempre incompleta, da história das identidades do Brasil nas duas coletâneas comemorativas dos 500 anos apresentadas anteriormente. Foi também no ano de 2000, por ocasião do centenário do nascimento de seu autor, comemorado em 15 de março de 2000, que a obra Casa-grande $\mathcal{E}$ senzala recebeu novas e surpreendentes interpretações. ${ }^{8}$

Intelectual de vasta obra, o sociólogo pernambucano Gilberto Freyre acabou permanecendo décadas, sobretudo entre intelectuais de esquerda e militantes da causa negra, representado pela interpretação, para usar uma expressão de Stuart Schwartz (1988), um tanto rósea da escravidão africana e da formação cultural brasileira, contida na obra Casa-grande $\mathcal{E}^{2}$

$8 \mathrm{Na}$ última década, sobretudo por ocasião do centenário de seu nascimento, a obra de Gilberto Freyre tem sido reinterpretada à luz de novas concepções historiográficas, que compõem as "valiosas exceções” aqui mencionadas. Ver, dentre outros, Araújo (1994); Falcão; Araujo (2001); e Pallares-Burke (2005). 
senzala, originalmente publicada em 1933. De acordo com essa tese, o escritor de Apipucos defendeu com convicção a ideia de que, graças à experiência anterior na Península Ibérica, sobretudo o contato com mouros e africanos, os colonizadores portugueses - cujo "passado étnico, ou antes, cultural, de povo indefinido entre a Europa e a África” (Freyre, 2002, p.80) reuniram as qualidades necessárias para conduzir a "democratização social no Brasil”.

Vencedores no sentido militar e técnico sobre as populações indígenas; dominadores absolutos dos negros importados da África para o duro trabalho da bagaceira, os europeus e seus descendentes tiveram, entretanto, de transigir com índios e africanos quanto às relações genéticas e sociais. A escassez de mulheres brancas criou zonas de confraternização entre vencedores e vencidos, entre senhores e escravos. Sem deixarem de ser relações - as dos brancos com as mulheres de cor - de "superiores" com "inferiores" e, no maior número de casos, de senhores desabusados e sádicos com escravas passivas, adoçaram-se, entretanto, com a necessidade experimentada por muitos colonos de constituírem família dentro dessas circunstâncias e sobre essa base. A miscigenação que largamente se praticou aqui corrigiu a distância social que doutro modo se teria conservado enorme entre a casa-grande e a mata tropical; entre a casa-grande e a senzala. O que a monocultura latifundiária e escravocrata realizou no sentido de aristocratização, extremando a sociedade brasileira em senhores e escravos com uma rala e insignificante lambujem de gente livre sanduichada entre os extremos antagônicos, foi em grande parte contrariado pelos efeitos sociais da miscigenação. A índia e a negra-mina a princípio, depois a mulata, a cabrocha, a quadrarona, a oitavona, tornando-se caseiras, concubinas e até esposas legítimas dos senhores brancos, agiram poderosamente no sentido da democratização social no Brasil. (Freyre, 2002, p.46) 
Embora não exclusivamente, coube ao grupo de sociólogos e historiadores liderados por Florestan Fernandes - em suas longas pesquisas históricas a respeito da escravidão africana praticada em diferentes áreas do Sul e do Sudeste brasileiro do século XIX, realizadas para a enunciação científica das causas do racismo no Brasil - a identificação, ou melhor, a denúncia, de um Gilberto Freyre inventor de um paraíso racial brasileiro que não encontrava respaldo em nenhum estudo empírico a respeito de nosso passado escravista. A essa interpretação juntaram-se as alegações de um Freyre membro das elites que descendiam dos senhores de engenho do Nordeste da América Portuguesa do período colonial e, em alguns aspectos, simpático aos regimes autoritários do Brasil e de Portugal do século XX. ${ }^{9}$ A qualidade das pesquisas documentais e a densidade teórica da crítica empregada pelos adeptos da Escola Paulista de Sociologia não deve, contudo, ser reduzida a uma mera rivalidade regional ou acadêmica entre os "intelectuais uspianos" e o "mestre de Apipucos". Consagrado com as mais altas honrarias e reconhecimentos intelectuais da época, Casa-grande $\mathcal{E}$ senzala tornou-se, por algumas décadas, a referência imediata para estudos comparativos entre o escravismo brasileiro e de outras regiões das Américas, principalmente dos Estados Unidos. A visão adocicada da escravidão dos engenhos nordestinos quando comparada com os rigores do cativeiro de outros lugares acabou, em algumas obras publicadas nos Estados Unidos, por efetivamente colocar em causa o efeito deletério do cativeiro no Brasil. ${ }^{10}$

9 Para a crítica ao pensamento de Freyre ver Leite (2002). No âmbito da chamada Escola Paulista de Sociologia destacam-se, no que concerne ao debate com Freyre, as obras: Bastide; Fernandes (1955); Ianni (1988); Cardoso (1977); Costa (1998); Queiroz (1977). Tratei mais amplamente deste debate em Ferreira $(2005,2011)$.

10 Para uma visão mais ampla dessas visões comparativas entre a escravidão praticada no sul dos Estados Unidos da América e no Brasil a partir da obra de Freyre, ver: Holanda (1977); Queiroz (1983, 1988); e Schwartz, Stuart (2001). 
A leitura de um Freyre relativista e racista, o pai da "democracia racial brasileira", leitura predominante durante as décadas de 1970 e 1980 no Brasil, pareceu, no entanto, carente de novas indagações aos olhos de uma nova geração de historiadores profissionais, formada no auge dos debates realizados por ocasião das comemorações do centenário da abolição do cativeiro de africanos e descendentes no país - no período marcado pela significativa ampliação dos programas de pós-graduação em história no Brasil. Uma pergunta, em particular, parecia - e isso afirmamos com base nos estudos que sobre o tema surgiram na década seguinte e que adiante trataremos - estar latente: quais os diálogos intelectuais estabelecidos por Freyre nos anos que antecederam a publicação de Casa-grande Ė senzala?

Uma pista para a solução de tal questionamento vinha indicada na própria literatura acadêmica dos anos 1960, no famoso prefácio de Antonio Candido ao livro Raízes do Brasil, de Sérgio Buarque de Holanda. Como é sabido, o início do texto de Candido é o da construção de uma geração, a dele próprio, conformada pela leitura de três obras fundamentais:

Casa-grande E senzala, de Gilberto Freyre, publicado quando estávamos no ginásio; Raízes do Brasil, de Sérgio Buarque de Holanda, publicado quando estávamos no curso complementar; Formação do Brasil contemporâneo, de Caio Prado Júnior, publicado quando estávamos na escola superior. (Candido, 1995, p.9)

Para Candido, as três obras representavam uma sobrevivência do "radicalismo intelectual e análise social que eclodiu após a Revolução de 1930”, e, ainda assim, não silenciado pelo Estado Novo (Candido, 1995, p.9). Especificamente quanto a Freyre, Candido lamenta "os rumos tomados posteriormente pelo autor", mas reconhece "a força revolucionária, o impacto libertador" que representou Casa-grande É senzala. Na opinião do autor de Formação 
da literatura brasileira (1959), ao trazer para o primeiro plano os aspectos mais íntimos do patriarcalismo que se configurou no Brasil, a história da alcova e a importância dos escravos africanos no "nosso modo de ser mais íntimo", Freyre, dispondo de um vigoroso volume de informação, fontes pouco usadas ou até mesmo ignoradas por intelectuais anteriores, dotado da capacidade de improvisar e de uma técnica de exposição sedutora, "coordenava os dados conforme pontos de vista totalmente novos no Brasil de então" (Candido, 1995, p.10). Ao lado de Caio Prado Júnior, Sérgio Buarque de Holanda e Freyre, "a obra por tantos aspectos penetrante e antecipadora de Oliveira Vianna já parecia superada, cheia de preconceitos ideológicos e uma vontade excessiva de adaptar o real a desígnios convencionais" (Candido, 1995, p.9).

Embora crítico, Candido reconhece que, antes dos três autores dos anos 1930, era de Francisco José de Oliveira Vianna a interpretação mais difundida a respeito da formação brasileira no ambiente acadêmico. No decorrer do texto de Candido, outros nomes como os de Sílvio Romero e Euclides da Cunha - cultores dos determinismos próprios da cena intelectual europeia do século XIX - também são mencionados, mas Vianna é colocado em destaque. Segundo Maria Stella Martins Bresciani, historiadora que produziu um aprofundado estudo sobre as apropriações de Oliveira Vianna por seus leitores contemporâneos e futuros,

o cuidado ou, diria até, o respeito acadêmico com que Antonio Candido se referiu a Oliveira Vianna, sem deixar de evidenciar suas críticas severas, contrasta com o tom ríspido e nada respeitoso da resenha de Sérgio Buarque de Holanda [ao livro de Vianna] Instituições políticas brasileiras, no final da década de 1940. (Bresciani, 2005, p.22)

A afirmação de Bresciani, destacando o tom desrespeitoso de Sérgio Buarque de Holanda, corrobora a ideia de que Vian- 
na era um dos principais alvos da geração de 1930. A autora, contudo, salienta que sua própria pesquisa foi motivada por um desconforto representado pela redução de toda a obra de Vianna aos aspectos ressaltados, desde os anos 1930, por Buarque de Holanda e perpetuados décadas depois, mesmo que de maneira mais polida, nos textos de Candido e de muitos dos seus leitores. Em maior ou menor medida - e de certa forma como ocorreu também com Gilberto Freyre entre os anos 1960 e 1980 -, essa partilha de opiniões contra Vianna acabou por mandá-lo "aos infernos", a uma espécie de banimento intelectual justificado pelo seu caráter tido pelos críticos como conservador e autoritário. Freyre certamente contribuiu para a edificação de tal imagem, foi também contra a ideia de superioridade racial contida no pensamento de Vianna que Freyre construiu sua interpretação do Brasil e dos brasileiros - contra "o Professor Oliveira Vianna, o maior místico do arianismo que ainda surgiu entre nós" (Freyre, 2002, p.362).

Assinado por Oliveira Vianna, em novembro de 1918, o prefácio do primeiro volume de Populações meridionais do Brasil (Populações rurais do Centro-Sul-Paulistas - Fluminenses - Mineiros), era uma proposta de identificação dos tipos ideais fundamentais do povo brasileiro: o sertanejo, habitante dos sertões do Norte; o matuto, habitante das matas do centro-sul; e o gaúcho, habitante dos pampas do extremo sul. Tal identificação tinha um caráter prático. Os ensaios, que acabaram por não serem totalmente concluídos, apresentavam-se como uma contribuição aos dirigentes do país para o conhecimento objetivo do povo brasileiro. Uma efetiva proposta, um projeto político para o país. A questão do nomeado cruzamento de raças era, para Vianna, uma espécie de "calcanhar de Aquiles" da nossa formação histórica. Contra essa fraqueza só havia, na opinião do autor, a "função verdadeiramente providencial" dos "preconceitos de cor e sangue" (Vianna, 1987, p.103). Assim, Vianna se referia 
aos preconceitos de cor e sangue: "São admiráveis aparelhos seletivos, que impedem a ascensão até às classes dirigentes desses mestiços inferiores, que formigam nas subcamadas da população dos latifúndios e formam a base das bandeiras colonizadoras" (Vianna, 1987, p. 103). No mesmo Populações meridionais do Brasil, Vianna se detém longamente em considerações a respeito do mulato. Segundo o sociólogo e jurista, visto como um tipo único, fruto dos encontros entre brancos e negros, o mulato era apenas uma abstração. Em sua opinião, era perfeitamente possível a distinção, numa série muito variada de possibilidades, entre o mulato inferior e o superior.

Em regra, o que chamamos de mulato é o mulato inferior, incapaz de ascensão, degradado nas camadas mais baixas da sociedade e provindo do cruzamento do branco com o negro de tipo inferior. Há, porém, mulatos superiores, arianos pelo caráter e pela inteligência ou, pelo menos, susceptíveis de arianização, capazes de colaborar com os brancos na organização da civilização do país. São aqueles que, em virtude de caldeamentos felizes, mais se aproximam, pela moralidade e pela cor, do tipo da raça branca. Caprichos de fisiologia, retornos atávicos, em cooperação com certas leis antropológicas, agindo de um modo favorável, geram esses mestiços de escol. Produtos diretos do cruzamento de branco e negro, herdam às vezes, todos os caracteres psíquicos e, mesmo, somáticos da raça nobre. Do matiz do cabelo à coloração da pele, da moralidade dos sentimentos ao vigor da inteligência, são de uma aparência perfeitamente ariana. (Vianna, 1987, p.100)

É inegável a importância conferida por Vianna ao papel desempenhado por esse mestiço de casta superior em todo o processo do estabelecimento do Engenho Vicentino e da conquista do hinterland. É possível afirmar ademais que é a ele e não ao que chama de inferior que Vianna dedica o maior número de 
referências no decorrer de todo o livro. No entanto, quanto aos mestiços inferiores, o autor é taxativo, condena-os ao desaparecimento por seleção natural. Para Vianna, os mestiços que muito destoavam dos brancos estavam irremediavelmente presos à sua condição, jamais ascenderiam.

Os mestiços inferiores, os menos dissimuláveis, os facilmente reconhecíveis, os estigmatizados - os "cabras", os "pardos", os "mulatos", os "fulos", os "cafuzos", estes são implacavelmente eliminados [...] Esses degradados da mestiçagem não têm o mais leve desejo de ascender, de sair de sua triste existência de párias. Centro de tendências étnicas opostas, que se neutralizam, a sua vontade como que se dissolve. Por fim, desfecham na abulia. E ficam eternamente no plano da raça inferior. (Vianna, 1987, p.103 e 105)

Enxergar em Vianna a precisa tradução para o universo brasileiro de uma leitura racial, muito em voga na Europa do século XIX, contra a qual Freyre teria se insurgido é bastante sedutor. Explica, à primeira vista, o porquê da produção de uma interpretação do Brasil baseada na mestiçagem como elemento decisivo de construção do Brasil e dos brasileiros. Mas tal leitura também se mostraria limitada. Os caminhos que a historiografia especializada tomou indicaram que mesmo valorizando a miscigenação, colocando, ao lado do luso, o negro e o índio como civilizadores em nosso período colonial, Freyre não via na estabilidade das relações estabelecidas pelas raças em contato em nossa história a argamassa usada na edificação do brasileiro.

Na última década do século XX, veio a lume um novo livro sobre Freyre, sobre sua obra mais conhecida e sobre sua tese a respeito daquilo que nos constituiu como povo, ou a respeito daquilo que temos chamado ao longo deste ensaio de identidade do Brasil e dos brasileiros analisada pela historiografia contemporânea. Em 1994, Ricardo Benzaquen de Araújo lançava 
aquela que seria a primeira edição de Guerra e paz, livro que devolvia, já no subtítulo, Casa-grande $\mathcal{E}$ senzala ao seu tempo, que o flagrava antes mesmo das famosas apropriações norte-americanas do texto. Ali, com uma perspectiva radicalmente histórica, no sentido da busca por evitar os anacronismos, a obra de Freyre era relida nos anos de sua publicação, a década de 1930. Em lugar da convencional atribuição a Freyre da invenção de um Brasil constituído por harmoniosas relações raciais, capitaneadas pela plasticidade europeia representada pelo luso, Araújo evidenciava a interpretação do que o próprio Freyre chamou de "antagonismos em equilíbrio". A novidade não estava apenas na inversão do sinal negativo da miscigenação, como vimos anteriormente, num suposto diálogo com os argumentos evidenciados em Oliveira Vianna e em tantos outros estudiosos. Estava sim na construção de uma experiência histórica da constituição de um povo a partir de identidades distintas que, uma vez em contato, se moldaram mútua e sucessivamente, inclusive por meio de relações marcadas pela violência, mas que não abandonaram, como se pensou, suas características próprias, aquilo que as configurava como partes de um todo. Não havia uma identidade estável, muito menos desprovida de conflitos, mas uma constante interpenetração de culturas - que comportava perfeitamente escravos capazes de civilizarem seus senhores, sem que deixassem de ser negros e brancos, africanos e europeus e assim por diante - e que marcaria a ação dos portugueses em toda a sua aventura colonizadora. Embora a obra de Araújo trate de muitos outros aspectos das teses de Freyre, acreditamos que sua nova interpretação sobre o sentido de mestiçagem em Casa-grande $\mathcal{E}$ senzala tenha sido o ponto alto das contribuições do livro para o debate sobre a peculiar identidade do Brasil e dos brasileiros na historiografia contemporânea.

Outro ponto da obra de Freyre a ser revisitado no início do século XXI dizia respeito à sua trajetória intelectual. Seus 
estudos, iniciados no Colégio Americano Batista do Recife, tiveram continuidade nos Estados Unidos. Primeiramente, entre 1918 e 1920, o então futuro Mestre de Apipucos estudou na Universidade de Baylor, no Texas, mais tarde transferiu-se para Universidade de Columbia, Nova York. Foi em Columbia que manteve o contato com o antropólogo alemão, radicado nos Estados Unidos da América, Franz Boas, relatados logo no prefácio à primeira edição de Casa-grande E̋ senzala:

Foi o estudo de Antropologia sob a orientação do Professor Boas que primeiro me revelou o negro e o mulato no seu justo valor - separados dos traços de raça, os efeitos do ambiente ou da experiência cultural. Aprendi a considerar fundamental a diferença entre raça e cultura; a discriminar os efeitos de relações puramente genéticas e os de influências sociais, de herança cultural e de meio. Neste critério de diferenciação fundamental entre raça e cultura assenta todo o plano deste ensaio. Também no da diferenciação entre hereditariedade de raça e hereditariedade de família. (Freyre, 2002, p.45)

Talvez um dos mais incisivos críticos do método evolucionista, Boas pouco a pouco se tornou um adversário declarado das explicações deterministas, fossem elas de cunho biológico, geográfico, econômico ou até mesmo histórico. Boas era também um crítico da utilização do racismo como explicação de características culturais. Segundo ele, nenhum estudo até então tinha oferecido provas convincentes da relação direta entre raça e cultura. De acordo com o autor, o erro fundamental das então modernas teorias sociais era estender o conceito de hereditariedade individual ao de hereditariedade racial:

A hereditariedade atua somente em linhagens de descendência direta. Não há unidade de descendência em qualquer das raças 
existentes, e nada nos autoriza a supor que as características mentais de algumas poucas linhagens familiares selecionadas sejam compartilhadas por todos os membros de uma raça. [...] Qualquer tentativa de explicar as formas culturais numa base puramente biológica está fadada ao fracasso. (Boas, 2005, p.60)

Mais uma vez, mostrava-se tentador, simplesmente, situar Freyre numa linha de rejeição das explicações racistas em voga na época entre os discípulos de Boas nos Estados Unidos. Coube, no entanto, em grande medida, à obra Gilberto Freyre: um vitoriano nos trópicos, publicada em 2005, pela historiadora Maria Lúcia Pallares-Burke, realizar uma análise exaustiva dos registros de estudos de Freyre nos EUA, que incluía sua correspondência, diários e notas de cursos e conferências. $\mathrm{O}$ estudo acabou por salientar, embora esse não fosse o objetivo primordial da historiadora, que a presença de Boas na formação do sociólogo pernambucano foi, por vezes, supervalorizada, em alguns casos, pelo próprio Freyre. O contato efetivo com Boas, desenvolvido no início dá década de 1920, certamente o estimulou ao estudo da antropologia, mas a incorporação das temáticas então já tratadas pelo antropólogo alemão só se daria um decênio mais tarde nos textos de Freyre. O que predominava, segundo a historiadora, na década que antecedeu Casa-grande $\mathcal{E}$ senzala, em textos publicados em jornais e cartas aos amigos, era um Freyre mais interessado em analisar a importância do europeu na trajetória que conduzia à civilização, inclusive, em uma resenha, teria detalhado com algum entusiasmo os violentos processos de controle dos escravos adotados com sucesso no sul dos Estados Unidos. O estudo de Pallares-Burke, entretanto, não se interessa em substituir uma verdade pela outra, não pelo menos no sentido de devolver ao leitor interessado um Freyre racista aos moldes dos Oitocentos, mas de mostrar aspectos aparentemente inconciliáveis que conviveram na trajetória de forma- 
ção do sociólogo, até que a notoriedade alcançada por sua obra mais importante o imortalizasse como o defensor da relação das culturas no âmbito da família patriarcal como base histórica da nossa estruturação como povo.

$\mathrm{Na}$ segunda década do século XXI, o interesse pela obra de Freyre parece não ter se desmobilizado. Muito menos o desejo de encontrar nessa forma exemplar de compreender e inventar uma identidade brasileira, de alguma forma, quais caminhos foram trilhados na tentativa de superar problemas que nos parecem ainda tão contemporâneos. Depois de numerosos estudos interessados na tese acadêmica e na trajetória intelectual que o conduziram a Casa-grande $\mathcal{E}$ senzala, também a linguagem assumiu - entre discípulos de Clio - o lugar central de entendimento da obra desse cientista social, agora visto "a meio-caminho entre o poeta e o historiador". Em Um estilo de História: a viagem, a memória, o ensaio: sobre Casa-grande \& senzala e a representação do passado (2011), Fernando Nicolazzi assim sintetiza a obra maior do escritor de Apipucos:

[...] o canto épico dos feitos heroicos nos tempos primeiros (mesmo que um herói às avessas, como o senhor deitado na rede cedendo às pressões fisiológicas que incomodavam seu corpo), sem o prejuízo imponente dos deuses interferindo nos destinos dos homens, mas com o fardo das intempéries do meio, das raças, das culturas. $\mathrm{O}$ livro constitui-se assim como o atestado histórico de nascimento de certo povo e de certo tipo de sociedade; o primeiro sopro de vida narrado no instante mesmo de seu suspiro derradeiro. (Nicolazzi, 2011, p.451)

Surgido na contiguidade entre criador e criatura, o ensaio do sociólogo pernambucano é visto pelo pesquisador como uma espécie de certidão de nascimento que congrega imaginação criadora e investigação científica num esforço contínuo de dar 
a conhecer ao leitor, muitas vezes um leitor desconfiado, uma autêntica representação do passado. O que se lê em Casa-grande Ẻ senzala é o texto de quem esteve lá, que se lembra do que viu e demonstra a validade de tais memórias com fartos exemplos documentais, tudo cosido por uma escrita sedutoramente heterodoxa, que não deixa evidenciar, em nenhum momento, a separação entre o pesquisador e seu objeto de estudo, mas que confere a cada brasileiro, e ao próprio Brasil, uma espécie de relato primordial, como o que Homero legou aos gregos.

Pouco antes de encerrarmos esse ensaio, damos a palavra a um dos ilustres descendentes da geração dos anos 1950 e 1960 que, a partir de São Paulo, se encarregou de colocar um tijolo a mais na imagem de Freyre como um dos pais da "democracia racial brasileira". ${ }^{11}$ Lançado em 2013, o livro Pensadores que inventaram o Brasil, traz reflexões do sociólogo e ex-presidente da República Fernando Henrique Cardoso sobre homens ${ }^{12}$ que, desde o século XIX, se encarregaram de explicar e, cada um ao seu modo, inventar o Brasil, enquanto tentavam explicar a "formação" do país. Aos seus olhos, uma obsessão que principiou ainda nos tempos da Independência, quando José Bonifácio deixou de se declarar paulista ou português para se autointitular brasileiro, despendendo sistematicamente suas energias

11 No posfácio que escreveu para a obra de Cardoso, José Murilo de Carvalho explica: "Durante os anos 1950-1960, e mesmo além, ele [Gilberto Freyre] foi uma bête noire para a intelectualidade uspiana, inclusive, e confessadamente para o próprio Fernando Henrique, e também para a esquerda em geral. Ele dividia com o fluminense Oliveira Vianna, xingado de reacionário, racista e elitista, o papel de saco de pancada da intelectualidade de esquerda. Gilberto Freyre, acusava-se, não tinha rigor científico, era conservador, saudosista do mundo patriarcal e escravista, criador do mito da democracia racial e o que mais seja" (Cardoso, 2013, p.292-3).

$12 \mathrm{Na}$ obra, Fernando Henrique Cardoso (2013) analisa - em textos produzidos ao longo de 35 anos (1978-2013) para introduções, resenhas, aulas e conferências - as principais obras de: Joaquim Nabuco, Euclides da Cunha, Paulo Prado, Gilberto Freyre, Sérgio Buarque de Holanda, Caio Prado Júnior, Antonio Candido, Florestan Fernandes, Celso Furtado e Raymundo Faoro. 
no esforço de "compreender o que nós, brasileiros, somos; ou melhor; como fazer de todos, inclusive dos escravos, parte da mesma nação" (Cardoso, 2013, p.10). Embora os textos tenham sido escritos em tempos distintos e para fins diversos, é oportuno observar que ao tratar da contribuição de Gilberto Freyre para a invenção do Brasil, Cardoso nos brinda com dois textos "Casa-grande \& senzala clássico", republicação de "Um livro perene", apresentação redigida para uma reedição de Casa-grande Eं senzala de 2005 e "Gilberto Freyre perene", texto que serviu de base a uma conferência proferida, em agosto de 2010, durante a Festa Literária Internacional de Paraty (FLIP), portanto, ensaios que contêm posições relativamente recentes do sociólogo paulista sobre o pernambucano. Sobre Freyre, ainda há longas menções no texto que encerra a obra, republicação de uma aula magna ministrada por Cardoso, em 1993, no Instituto Rio Branco.

A novidade das interpretações sobre a obra fundamental de Freyre aparece, de maneira geral, no reconhecimento da perenidade de sua tese sobre a formação do Brasil. Fernando Henrique, ainda crítico, porém distanciado do cenário acadêmico e político dos anos 1960, reconhece pontos positivos na obra, na presença de "muita pesquisa" "por trás das descrições, às vezes romanceadas e mesmo distorcidas", no pioneirismo da análise da vida íntima, da dimensão privada, dos sentimentos e do cotidiano na formação do brasileiro, estratégia interpretativa que só se tornaria corrente no Brasil mais tarde, com a presença, entre nós, de cientistas sociais e historiadores franceses. Cardoso não deixa de se mostrar, contudo, incomodado com a interpretação que, como vimos anteriormente, valoriza a ideia de "equilíbrio dos contrários" ou "antagonismos em equilíbrio" como definidora do tipo de identidade que Freyre teria dito compor a sociedade brasileira. Para Cardoso, tal ideia não é incoerente com a obra, mas apresenta limitações. O sociólogo paulista chega mesmo a 
desafiar quem explique "por suas características metodológicas, o mal-estar que a obra de Gilberto Freyre causou, e quem sabe ainda cause, na Academia" (Cardoso, 2013, p.86). Após passar em revista os temas mais significativos do que chamou de insights de Freyre sobre a invenção do Brasil, sempre com muitos elogios a respeito da qualidade da narrativa e críticas sobre as oscilações argumentativas das teses do escritor de Apipucos, Cardoso acaba por concluir que o sociólogo pernambucano cria sim um mito fundador, se não o da democracia racial, o mito do equilíbrio de contrários - que não deixa de explicar muito da sociedade que o produziu - responsável por projetar no futuro as características constitutivas do Brasil e dos brasileiros.

\section{Considerações finais ou "Nenhuma forma de tratar as identidades do Brasil existe"}

Outra coletânea organizada por João Cezar de Castro Rocha foi publicada, primeiramente, nos Estados Unidos no ano 2001, em um número especial da revista Portuguese Literary and Cultural Studies, com o título Brazil 2001: A Revisionary History of Brazilian Literature and Culture. Em uma nova versão, traduzida para o português e acrescida de 23 ensaios, essa coletânea foi publicada em 2003 com a colaboração de Valdei Lopes de Araujo, com o instigante título Nenhum Brasil existe.

“O 'Brasil' não existe, mas é o mesmo 'Brasil' que não se rende às tentativas de traduzi-lo em substanciais volumes de história literária e cultural" como a pequena enciclopédia de 1.107 páginas que carrega "um paradoxo que não deve ser resolvido" (Rocha, 2003, p.17). Inspirado no poema "Hino Nacional" de Carlos Drummond de Andrade, e com uma parte dedicada a Gilberto Freyre, a menção a esse Nenhum Brasil existe vem aqui à guisa de conclusão para nos auxiliar a encerrar esse ensaio. Ao 
direcionarmos nosso olhar para essa primeira década do século XXI a fim de definir como historiadores e cientistas sociais têm lidado com o desafio de estudar a identidade do Brasil, podemos concluir que "Nenhuma forma de tratar as identidades do Brasil existe" ou que, pelo menos, o tema não se esgotará nem nas melhores coletâneas, nem nas mais argutas interpretações dos intelectuais consagrados como nossos maiores inventores. Para existirmos parece ser eterno o exercício de perguntarmos: $\mathrm{O}$ que é o Brasil? 


\section{Referências bibliográficas}

ABREU, C. Capítulos de história colonial (1500-1800). Belo Horizonte: Itatiaia; São Paulo: Publifolha, 2000.

ALDRIDGE, D. Health, the Individual, and Integrated Medicine: revisiting an aesthetic of health care. London; New York: Jessica Kingsley Publishers, 2004.

ALGUNAS cosas que de la Provincia del Brasil se proponen nuestro Padro General este anno de 1579 y respuestas a ellas. Coleção Brasiliana 2,29v.

ALMEIDA, L. F. R. A Distante Harmonia: Marcel Mauss e a nação. Ponto-e-vírgula, PUC-SP. n.1, 1ํㅗㄴ semestre de 2007.

ALONSO, A.; TITAN JR., S. Nota Introdutória. In: RENAN, E. O que é uma nação? Revista Plural, Sociologia, USP, v.4, 154-175, 1ํsemestre de 1997.

AMADO, W. (Org.). A Religião e o Negro no Brasil. São Paulo: Loyola. 1989.

ANCHIETA, J. Cartas, informações, fragmentos históricos e sermões. Rio de Janeiro: Civilização Brasileira, 1933.

ANDERSON, B. Comunidades Imaginadas: reflexões sobre a origem e a difusão do nacionalismo. São Paulo: Companhia das Letras, 2008.

ANDREWS, G. R. O protesto político negro em São Paulo (1888-1988). Estudos Afro-Asiáticos, n.21, Rio de Janeiro, 1991.

ANDREWS, G. R. Relações raciais entre negros e brancos em São Paulo. São Paulo: Ed. Anhembi, 1971.

ANHORN, C. T. G. Um objeto de ensino chamado História: a disciplina de História nas tramas da didatização. Tese (Doutorado). Rio de Janeiro: PUC, Departamento de Educação, 2003. 
ANÔNIMO. Journal d'un Voyage. In: FRANÇA, J. M. C. Visões do Rio de Janeiro colonial. Antologia de textos (1531-1800). São Paulo: Ed. José Olympio, 2008.

ANTONIL, A. J. (João Antônio Andreoni, S.J.) Cultura e opulência do Brasil por suas drogas e minas. Texto confrontado com o da edição de 1711; com um estudo biobibliográfico por Affonso de E. Taunay; nota bibliográfica de Fernando Sales; e vocabulário e índices antroponímico, toponímico e de assuntos de Leonardo Arroyo. 3.ed. Belo Horizonte: Ed. Itatiaia; São Paulo: Edusp, 1982.

ARAUJO, I. 100 Acontecimentos que marcaram a História das Assembleias de Deus no Brasil. Rio de Janeiro: Casa Publicadora das Assembleias de Deus, 2011.

ARAÚJO, R. B. Guerra e paz: Casa-Grande \& Senzala e a obra de Gilberto Freyre nos anos 30. Rio de Janeiro: Ed. 34, 1994.

AXT, G.; SCHÜLER, F. L. (Org.). Intérpretes do Brasil: cultura e identidade. 2.ed. Porto Alegre: Artes e Ofícios, 2011 [1.ed. 2004].

AZEVEDO, C. et al. Umbanda, religião do Brasil. São Paulo: Obelisco, 1960.

AZEVEDO, C. M. M. Anti-racismo e seus paradoxos: reflexões sobre cota racial, raça e racismo. 2.ed. São Paulo: Annablume, 2004.

AZEVEDO, C. M. M. Onda Negra, Medo Branco: o negro no imaginário das elites do século XIX. Rio de Janeiro: Paz e Terra, 1987.

AZEVEDO, C.; ALMEIDA, M. R. C. Identidades plurais. In: ABREU, M.; SOIHET, R. (Org.). Ensino de História: conceitos, temáticas e metodologias. Rio de Janeiro: Casa da Palavra, 2003.

BACZKO, B. Imaginação social. In: ROMANO, R. (Org.). Enciclopédia Einaudi. v.5. Lisboa: Imprensa Nacional; Casa da Moeda, 1985.

BAGNO, M. A norma oculta: língua \& poder na sociedade brasileira. São Paulo: Parábola, 2003.

BALAKRISHNAN, G. (Org.). Um mapa da questão nacional. Rio de Janeiro: Contraponto, 2000.

BARBOSA, A. G. O português escrito no século XVIII: fontes reunidas na Biblioteca Nacional do Rio de Janeiro. In: CASTILHO, A. T. (Org.). Para a história do português brasileiro. v.I. São Paulo: Humanitas, 1998. p.229-238.

BARKAN, E. The retreat of scientific racism: changing concepts of race in Britain and the United States between the world wars. Cambridge: Cambridge University Press, 1992. 
BASTIDE, R.; FERNANDES, F. Relações raciais entre negros e brancos em São Paulo: ensaio sociológico sobre as origens, as manifestações e os efeitos do preconceito de cor no município de São Paulo. São Paulo: Anhembi, 1955.

BASTOS, E. R. Octavio Ianni: diversidade e desigualdade. In: BOTELHO, A.; SCHWARCZ, L. M. (Org.). Um enigma chamado Brasil. São Paulo: Companhia das Letras, 2009. p.378-389.

BAUMAN, Z. A sociedade individualizada: vidas contadas e histórias vividas. Rio de Janeiro: Jorge Zahar, 2008.

BAUMAN, Z. Identidade: entrevista a Benedetto Vecchi. Rio de Janeiro: Jorge Zahar, 2005.

BAXTER, A. N.; LUCCHESI, D. A relevância dos processos de pidginização e crioulização na formação da língua portuguesa no Brasil. Estudos linguísticos e literários, v.19, p.65-84, mar. 1997.

BECK, U. O que é globalização? São Paulo: Paz e Terra, 1999.

BENCI, Jorge. Economia cristã dos senhores de escravos. Livro brasileiro de 1700. Estudo preliminar de Pedro A. Figueira. São Paulo: Editorial Grijalbo. s.d.

BERG, D. Enviado por Deus. Rio de Janeiro: Casa Publicadora das Assembleias de Deus, 2011 [1959].

BERGER, P. L.; LUCKMANN, T. A construção social da realidade. Petrópolis: Vozes, 2011.

BERMAN, M. Tudo o que é sólido desmancha no ar. A aventura da modernidade. São Paulo: Companhia das Letras, 1986.

BERTTRAND, R. L'Histoire à parts égales. Récits d'une reencontre Orient-Occident (XVe-XVII ${ }^{e}$ siècle). Paris: Éditions du Seuil, 2011.

BHABHA, H. K. Disseminação: Tempo, narrativa e as margens da nação moderna. In: BESCU, H.; DUARTE, J. F.; GUSMÃO, M. (Org.) Floresta Encantada. Lisboa: Publicações Dom Quixote, 2001.

BOAS, F. Antropologia cultural. Rio de Janeiro: Jorge Zahar, 2005.

BOIA, L. Pour une histoire de l'imaginaire. Paris: Les Belles Lettres, 1998. BOTELHO, A.; SCHWARCZ, L. M. (Org.). Um enigma chamado Brasil. São Paulo: Companhia das Letras, 2009.

BOURDIEU, P. A economia das trocas simbólicas. São Paulo: Perspectiva, 1996.

BOURDIEU, P. A ilusão biográfica. In: Razões práticas. Sobre a teoria da ação. Campinas: Papirus, 2013.

BOURDIEU, P. O poder simbólico. Rio de Janeiro: Bertrand Brasil, 2001. [Lisboa: Difel, 1989.]. 
BRASIL. Câmara dos Deputados. Projeto de Lei 1332/1983. Dispõe sobre ação compensatória, visando a implementação do principio da isonomia social do negro, em relação aos demais segmentos étnicos da população brasileira, conforme direito assegurado pelo artigo 153, parágrafo primeiro, da constituição da republica. 1983. Disponível em: <http:// www.camara.gov.br/proposicoesWeb/fichadetramitacao?idProposi cao $=190742>$. Acesso em: 9 ago. 2013.

BRASIL. Código Penal. Decreto-Lei № 2.848, de 7 de dezembro de 1940. Diário Oficial [da] República Federativa do Brasil, Poder Executivo, Brasília, DF, 31 dez. 1940. Disponível em: <http://www.jusbrasil. com.br/topicos/10622481/paragrafo-3-artigo-140-do-decreto-lei-n-2848-de-07-de-dezembro-de-1940>. Acesso em: 11 ago. 2013.

BRASIL. Constituição da República Federativa do Brasil. Brasília, 1988.

BRASIL. Decreto 4887 de 20 de novembro de 2003. Regulamenta o procedimento para identificação, reconhecimento, delimitação, demarcação e titulação das terras ocupadas por remanescentes das comunidades dos quilombos de que trata o art. 68 do Ato das Disposições Constitucionais Transitórias. Diário Oficial [da] República Federativa do Brasil, Poder Executivo, Brasília, DF, 21 nov. 2003. Disponível em: <http:// www.planalto.gov.br/ccivil_03/decreto/2003/d4887.htm>. Acesso em: 23 ago. 2013.

BRASIL. Instituto Nacional de Estudos e Pesquisas Educacionais Anísio Teixeira. Estatísticas sobre educação escolar indígena no Brasil. Brasília: Instituto Nacional de Estudos e Pesquisas Educacionais, 2007. Disponível em: <http://www.publicacoes.inep.gov.br/ arquivos/\%7B74843DB9-A72E-401A-8426-1186066262DB\%7D_1 educacaoindigenabrasil.pdf>. Acesso em 30 jul. 2013.

BRASIL. Instituto Nacional de Estudos e Pesquisas Educacionais Anísio Teixeira. Um olhar sobre a educação indígena com base no Censo Escolar de 2008. Brasília: Instituto Nacional de Estudos e Pesquisas Educacionais, 2009. Disponível em: <http://download.inep.gov.br/download/censo/2008/Educacao_Indigena_estudo2008.pdf>. Acesso em: 30 jul. 2013.

BRASIL. Instituto Nacional de Estudos e Pesquisas Educacionais Anísio Teixeira. Censo da Educação Superior. Brasília: Instituto Nacional de Estudos e Pesquisas Educacionais, 2009b. Disponível em: <http:// portal.inep.gov.br/web/censo-da-educacao-superior/censo-da-educacao-superior>. Acesso em: 30 jul. 2013.

BRASIL. Instituto Nacional de Estudos e Pesquisas Educacionais Anísio Teixeira. Mapa do Analfabetismo no Brasil. Brasília: Instituto Nacional 
de Estudos e Pesquisas Educacionais, s.d. Disponível em: <http:// www.publicacoes.inep.gov.br/arquivos/\%7B3D805070-D9D0 42DC-97AC-5524E567FC02\%7D_MAPA\%20DO\%20ANALFABETISMO\%20NO\%20BRASIL.pdf>. Acesso em: 30 jul. 2013.

BRASIL. Instituto Nacional de Estudos e Pesquisas Educacionais Anísio Teixeira. Censo Escolar de 2012: resumo técnico, 2013. Disponível em: <http://download.inep.gov.br/educacao_basica/censo_escolar/ resumos_tecnicos/resumo_tecnico_censo_educacao_basica_2012. pdf>. Acesso em: 30 jul. 2013.

BRASIL. Lei Afonso Arinos. Lei n. 1390 de 3 de julho de 1951. Diário Oficial [da] República Federativa do Brasil, Poder Executivo, Brasília, DF, 10 jul. 1951. Disponível em: <http://presrepublica.jusbrasil. com.br/legislacao/128801/lei-afonso-arinos-lei-1390-51>. Acesso em: 3 ago. 2013.

BRASIL. Lei Caó. Lei n. 7437 de 20 de dezembro de 1985. Disponível em: <http://www.cedine.rj.gov.br/files/legisla/federais/LEI_CAO. pdf $>$. Acesso em: 17 ago. 2013.

BRASIL. Lei № 12.711, de 29 de agosto de 2012. Dispõe sobre o ingresso nas universidades federais e nas instituições federais de ensino técnico de nível médio e dá outras providências. Diário Oficial [da] República Federativa do Brasil, Poder Executivo, Brasília, DF, 30 ago. 2012b. Disponível em: <http://www.planalto.gov.br/ccivil_03/_ato20112014/2012/lei/l12711.htm>. Acesso em: 18 ago. 2013.

BRASIL. Lei no 7.668, de 22 de agosto de 1988. Autoriza o Poder Executivo a constituir a Fundação Cultural Palmares - FCP e dá outras providências. Diário Oficial [da] República Federativa do Brasil, Poder Executivo, Brasília, DF, 23 ago. 1988. Disponível em: <http://www. planalto.gov.br/ccivil_03/leis/L7668.htm>. Acesso em: 17 ago. 2013.

BRASIL. Lei no 9.459, de 13 de maio de 1997. Altera os arts. 1e e 20 da Lei 7.716, de 5 de janeiro de 1989, que define os crimes resultantes de preconceito de raça ou de cor, e acrescenta parágrafo ao art. 140 do Decreto-lei no 2.848, de 7 de dezembro de 1940. Diário Oficial [da] República Federativa do Brasil, Poder Executivo, Brasília, DF, 14 maio 1997. Disponível em: <http://www.leidireto.com.br/lei-9459. html>. Acesso em: 23 ago. 2013.

BRASIL. Lei № 9.459, de 13 de maio de 1997. Altera os arts. 1e e 20 da Lei 7.716, de 5 de janeiro de 1989, que define os crimes resultantes de preconceito de raça ou de cor, e acrescenta parágrafo ao art. 140 
do Decreto-lei no 2.848, de 7 de dezembro de 1940. Diário Oficial [da] República Federativa do Brasil, Poder Executivo, Brasília, DF, 14 maio 1997. Disponível em: <http://www.leidireto.com.br/lei-9459. html>. Acesso em: 21 ago. 2013.

BRASIL. Lei provisória n. 111 de 21 de março de 2003, convertida na Lei 10978.

BRASIL. Ministério do Desenvolvimento Agrário. Instituto Nacional de Colonização e Reforma Agrária (INCRA). Legislação referente à política pública de regularização de territórios quilombolas. Brasília, 2011. Disponível em: <http://www.incra.gov.br/index.php/estrutura-fundiaria/quilombolas/file/107-legislacao-quilombola-condensada $>$. Acesso em: 21 ago. 2013.

BRASIL. Ministério do Planejamento. Plano Mais Brasil: mais desenvolvimento, mais igualdade, mais participação - PPA 2012-2015. 2012a. Disponível em: <http://www.secretariageral.gov.br/art_social/ forumppa/materiais-de-apoio/PPA_de_Bolso.pdf $>$. Acesso em: 12 ago. 2013.

BRASIL. Programa Nacional dos Direitos Humanos (PNDH I). 1996. Disponível em: <http://portal.mj.gov.br/sedh/pndh3/index.html >. Acesso em: 29 ago. 2013.

BRASIL. Programa Nacional dos Direitos Humanos (PNDH II). 2002. Disponível em: <http://portal.mj.gov.br/sedh/pndh/pndhII/ Texto\%20Integral\%20PNDH\%20II.pdf> Acesso em: 29 ago. 2013.

BRASIL. Secretaria de Políticas de Promoção da Igualdade Racial. 2013. Disponível em: <http://www.seppir.gov.br/sobre>. Acesso em: 11 ago. 2013.

BRASIL. Secretaria de Políticas de Promoção da Igualdade Racial. Programa Brasil Quilombola. 2013. Disponível em: < http://www.seppir.gov.br/comunidades-tradicionais/programa-brasil-quilombola $>$. Acesso em: 12 ago. 2013.

BRASIL. Senado Federal. Estatuto da Igualdade Racial. Brasília, 2003. Disponível em: <http://bvsms.saude.gov.br/bvs/publicacoes/pop_ negra/estatuto_racial.pdf>. Acesso em: 11 ago. 2013.

BREVE narração das cousas relativas aos Colégios e Residências da Companhia nesta Província Brasílica, no ano de 1584.

BURKE, P. Cultura Popular na Idade Moderna (Europa, 1500-1800). São Paulo: Companhia das Letras, 2010.

CALLOU, D. et al. O português do Brasil: polarização sociolinguística. In: CARDOSO, S. A. M. et al. (Org.). Quinhentos anos de história lin- 
guística do Brasil. Salvador: Secretaria de Cultura e Turismo do Estado da Bahia, 2006. p.257-292.

CANCLÍNI, N. G. Culturas hibridas: estrategias para entrar y salir de la modernidad. Buenos Aires: Sudamericana, 1992.

CANCLINI, N. G. Consumidores e cidadãos: conflitos multiculturais da globalização. Rio de Janeiro: Editora UFRJ, 1995.

CANDIDO, A. Os significados de Raízes do Brasil. In: HOLANDA, S. B. Raizes do Brasil. 26.ed. São Paulo: Companhia das Letras, 1995.

CANGUILHEM, G. La connaissance de la vie. Paris: Vrin, 2000.

CANGUILHEM, G. O normal e o patológico. Forense Universitária, 2000.

CANIELLO, M. A identidade como valor: reflexões sobre o ethos nacional brasileiro. Programa das Nações Unidas Para o Desenvolvimento PNUD, 2009.

CARDOSO, F. H. Capitalismo e escravidão no Brasil meridional: o negro na sociedade escravocrata do Rio Grande do Sul. Rio de Janeiro: Paz e Terra, 1977.

CARDOSO, F. H. Pensadores que inventaram o Brasil. São Paulo: Companhia das Letras, 2013.

CARDOSO, F. H.; IANNI, O. Cor e mobilidade social em Florianópolis. São Paulo: Nacional, 1960. Disponível em: <http://www.brasiliana. com.br/obras/cor-e-mobilidade-social-em-florianopolis/>. Acesso em: 15 ago. 2013.

CARDOSO, S. A. M.; MOTA, J. A. O projeto Atlas Linguístico do Brasil: antecedentes e estágio atual. Alfa, São Paulo, v.56, n.3, p.855870, 2012. Disponível em: <http://seer.fclar.unesp.br/alfa/article/ view/4924/4364>. Acesso em: 10 ago. 2013.

CARRETERO, M. Documentos de identidade: a construção da memória histórica em um mundo globalizado. Porto Alegre: Artmed, 2010.

CARRETERO, M.; ROSA, A.; GONZÁLEZ, M. F. (Org.) Ensino da História e Memória Coletiva. Porto Alegre: Artmed, 2007.

CARTA Pública ao Congresso Nacional. 2006. Disponível em: <http:// www.observa.ifcs.ufrj.br/carta/index.htm>. Acesso em: 21 ago. 2013.

CARTA de Anchieta aos padres e irmãos de Portugal. São Paulo de Piratininga, fins de abril de 1557.

CARTAS de Luiz Joaquim dos Santos Marrocos, escritas à sua família em Lisboa, de 1811 a 1821. Anais da Biblioteca Nacional do Rio de Janeiro, vol.LVI, 1934.

CARVALHO JR., E. Releitura do mito da "maldição de Cam”. Cruz das Almas/BA: FAMAM, 2011. 
CARVALHO, J. J. O confinamento racial do mundo acadêmico brasileiro. Revista USP, São Paulo, n.68, p.88-103, dez.-fev. 2005.

CARVALHO, J. M. Nação Imaginária: memória, mitos e heróis. In: NOVAES, A. A crise do Estado-Nação. Rio de Janeiro: Civilização Brasileira, 2003, p.397-418.

CARVALHO, J. M. O Motivo Edênico no Imaginário Social Brasileiro. Revista Brasileira de Ciências Sociais. São Paulo, v.13, n.38, out. 1998a. p.63-79.

CASTELLS, M. O poder da identidade. São Paulo: Paz e Terra, 1996.

CASTILHO, A. T. Para um programa de pesquisas sobre a história social do português de São Paulo. In: MATTOS E SILVA, R. V. (Org.). Para a história do português brasileiro. São Paulo: Humanitas, 2001. v.II. p.337-369.

CASTILHO, A. T. Prefácio. In: NARO, A. J.; SCHERRE, M. M. P. Garimpo das origens do português brasileiro. São Paulo: Parábola, 2007. p.11-15.

CAVALCANTI, M. L. V. C. Estigma e relações raciais na obra pioneira de Oracy Nogueira. In: BOTELHO, A.; SCHWARCZ, L. M. (Org.). Um enigma chamado Brasil. São Paulo: Companhia das Letras, 2009. p.254-267.

CERRI, L. F. A Política, a Propaganda e o Ensino da História. Cadernos. Cedes, Campinas, v.25, n.67, p.319-331, set.-dez. 2005.

CERRI, L. F. Ensino de História e nação na propaganda do "milagre econômico". Revista Brasileira de História. São Paulo, v.22, n.43, p.195224. 2002.

CERRI, L. F. Ensino de História e nação na propaganda do "milagre econômico". Brasil 1969-1973. Tese (Doutorado) - Campinas, 2000.

CHAMPION, F. Religieux flottante, écletisme et syncrétismes. In: DELUMEAU, J. (Org.). Le fait religieux. Paris: Fayard, 1993.

CHARTIER, R. A História Cultural: entre práticas e representações. Rio de Janeiro, Bertrand Brasil, 1990 [Lisboa: DIFEL, 1988].

CHARTIER, R. A História Hoje: dúvidas, desafios, propostas. Estudos Históricos, Rio de Janeiro, v.7, n.13, 1994, p.97-113.

CHARTIER, R. A história ou a leitura do tempo. Belo Horizonte: Autêntica, 2010.

CHARTIER, R. O mundo como representação. Estudos Avançados 11(5), 1991. p.173-191.

CHAUI, M. Brasil: mito fundador e sociedade autoritária. São Paulo: Fundação Perseu Abramo, 2000. 
CONDE, E. História das Assembleias de Deus no Brasil. Rio de Janeiro: Casa Publicadora das Assembleias de Deus, 2011 [1960].

CONFERENACIA NACIONAL CONTRA O RACISMO E INTOLERÂNCIA. Plano Nacional de Combate ao Racismo e à Intolerância. Carta do Rio. Rio de Janeiro, 2001. Disponível em: <http:// portal.mj.gov.br/sedh/rndh/Carta\%20do\%20Rio.pdf>. Acesso em: 13 ago. 2013.

CONTIER, A. D. Edu Lobo e Carlos Lyra: o nacional e o popular na canção de protesto (os anos 60). Revista Brasileira de História, v.18, n.35, São Paulo, 1998. Disponível em: <http://www.scielo.br/scielo. php? script $=$ sci_arttext\&pid $=\mathrm{S} 0102-01881998000100002>$.

CORDELIER, S. (Coord.). Nações e Nacionalismos. Lisboa: Dom Quixote, 1998.

CORREA, D. Francisco de Aquino. Discursos. Rio de Janeiro: Imprensa Nacional, 1944.

COSTA, E. V. Da senzala à colônia. 3.ed. São Paulo: Ed. Unesp, 1998.

COSTA, J. C. C. Teoria Social e Etnicidade: Uma Interpretação Hermenêutica das Noções de Nação e Raça na Contemporaneidade. Fragmentos de Cultura (Goiânia), v.17, p.1021-1046, 2007.

CUNHA, C. A. M. A arte de curar nos tempos da colônia: limites e espaços da cura. Recife: Fundação de Cultura da Cidade do Recife, 2004.

DAMATTA, R. Relativizando: uma introdução à antropologia social. Rio de Janeiro: Rocco, 1987.

DIAS, R. Agentecantamos. Folha de S. Paulo, São Paulo, 13 jul. 2013, p.A2. Disponível em: <http://acervo.folha.com.br/fsp/2013/07/13/2>. Acesso em: 30 jul. 2013.

DIEHL, A. A. Cultura historiográfica: memória, identidade e representação. Bauru, SP: EDUSC, 2002.

DOCUMENTOS para la historia argentina (DHA). Cartas anuas de la Provincia del Paraguay, Chile y Tucumán, de la Compañia de Jesús (1609-1614). Tomo XIX, Buenos Aires: Talleres S. A. Casa Jacobo Peuser, 1927.

DOMINGUES, P. Ações afirmativas para negros no Brasil: o início de uma reparação histórica. Espaço Aberto, n.29, p.164-176, maio-ago. 2005. Disponível em: <http://www.redalyc.org/pdf/275/27502913. pdf>. Acesso em: 21 ago. 2013.

DOMINGUES, P. Constantemente derrubo lágrimas: o drama de uma liderança negra no cárcere do governo Vargas. TOPOI, v.8, n.14, p.146-171, jan.-jun. 2007a. Disponível em: <http://www.revista- 
topoi.org/numeros_anteriores/topoi14/Topoi\%2014_artigo\%205. pdf>. Acesso em: 9 ago. 2013.

DOMINGUES, P. J. Pérolas Negras: A participação do negro na Revolução Constitucionalista de 1932. Afro-Ásia.n.29-30, p.199-245, 2003. Disponível em: <http://www.afroasia.ufba.br/pdf/afroasia_ n29_30_p199.pdf>. Acesso em: 10 ago. 2013.

DOMINGUES, P. Movimento Negro Brasileiro: breves apontamentos históricos. Revista Tempo, n.23, p.100-122, 2007b. Disponível em: $<$ http://www.scielo.br/pdf/tem/v12n23/v12n23a07>. Acesso em: 8 ago. 2013.

DOUXAMI, C. Teatro Negro: a realidade de um sonho sem sono. Afro-Ásia, n. 26, p.313-363, 2001.

DREHER, M. A Igreja latino-americana no contexto mundial. São Leopoldo: Sinodal, 1999.

DUARTE, P. C. Os afrodescendentes e a políticas de inclusão no Brasil: a Marcha Zumbi dos Palmares e a Lei 10639-03. Ação educativa, p.6572, 2008. Disponível em: <http://www.famper.com.br/download/ paulo.pdf>. Acesso em: 9 ago. 2013.

DUMONT, L. Essais sur le individualisme. Paris: Le Seuil, 1983.

DURHAM, E. Desigualdade educacional e cotas para negros nas universidades. Novos Estudos CEBRAP, 2003.

EPISCOPADO BRASILEIRO. Carta Pastoral do Episcopado Brasileiro ao clero e aos fiéis de suas dioceses por ocasião do Centenário da Independência. Rio de Janeiro: Marques, Araujo \& Companhia, 1922.

EPSTEIN, D. M. A balada de Bob Dylan: um retrato musical. Rio de Janeiro: Zahar, 2012.

ESPAGNE, M. Transferências Culturais e História do Livro. Revista Livr, . NELE/USP, n.2. Cotia: Ateliê, 2012.

FALCÃO, J.; ARAUJO, R. M. B. (Org.). O imperador das ideias: Gilberto Freyre em questão. Rio de Janeiro: Topbooks, 2001.

FARACO, C. A. Norma-padrão brasileira: desembaraçando alguns nós. In: BAGNO, M. (Org.). Linguística da norma. São Paulo: Loyola, 2002. p.37-61.

FAUSTO, B. História do Brasil. São Paulo: Edusp, 1994.

FERREIRA, R. A. Crimes em comum: escravidão e liberdade sob a pena do Estado imperial brasileiro (1830-1888). São Paulo: Ed. Unesp, 2011.

FERREIRA, R. A. Senhores de poucos escravos: cativeiro e criminalidade num ambiente rural, 1830-1888. São Paulo: Ed. Unesp, 2005.

FLORES, M. B. R. Tecnologia e estética do racismo: ciência e arte na política da beleza. Chapecó/SC: Argos, 2007. 
FLORES, M. B. R. Xul Solar e o Brasil - Sobre uma Biblioteca muito particular. Eadem Utraque Europa, Revista del Centro de Estudios en Historia Cultural e Intelectual Edith Stein de la Escuela de Humanidades, v.9, p.119-154, 2010.

FOUCAULT, M. O nascimento da clínica. Rio de Janeiro: Ed. Forense Universitária, 2001.

FOUCAULT, M. O nascimento da medicina social. In: FOUCAULT, M. Microfísica do poder. Rio de Janeiro: Graal, 1984.

FRANÇA, J. M. C. Literatura e sociedade no Rio de Janeiro oitocentista. Lisboa: Imprensa Nacional-Casa da Moeda, 1999.

FRANCO, F. M. Medicina theologica, ou supplica humilde, feita a todos os senhores confessores, e directores, sobre o modo de proceder com seus penitentes na emenda dos peccados, principalmente da lascívia, cólera ebebedice. Lisboa: Na offi. de Antonio Rodrigues Galhardo, impressor da Serenissima Casa do Infantado, 1794.

FREIRE, J. R. B. Rio Babel: a história das línguas na Amazônia. Rio de Janeiro: Atlântica, 2004.

FREYRE, G. Casa-grande $\mathcal{E}$ senzala: formação da família brasileira sob o regime de economia patriarcal. São Paulo: Global, 2007. [46. ed. Rio de Janeiro: Record, 2002; 34. ed. Rio de Janeiro/São Paulo: Record, 1998; 1. ed. 1933].

FREYRE, G. O mundo que o português criou. Rio de Janeiro: José Olympio, 1940.

FRÓES, M. Jovem Guarda em ritmo de aventura. São Paulo: Ed. 34, 2000.

FRY, P. et. al. Divisões perigosas: políticas raciais no Brasil contemporâneo. Rio de Janeiro: Civilização Brasileira, 2007.

FRY, P. Introduzindo o racismo. O Globo, 21 mar. 2003. Disponível em: $<$ https://www.ufmg.br/inclusaosocial/?p=33>. Acesso em: 12 ago. 2013.

FUNDAÇÃO CULTURAL PALMARES. Comunidades quilombolas. 2013. Disponível em: <http://www.palmares.gov.br/quilombola/>. Acesso em: 17 ago. 2013.

FURET, F. O nascimento da história. In: FURET, F. A oficina da história. Lisboa: Gradiva, 1989. p.109-135.

GARCIA, M. O indivíduo, a genética e a história. Disponível em: <http:// cienciahoje.uol.com.br/instituto-ch/destaques/2012/06/o-individuo-a-historia-e-a-genetica>. Acesso em: 17 ago. 2013.

GAUER, R. M. C. Violência e medo na fundação do Estado-Nação. Civitas-Revista de Ciências Sociais, a.1, n.2, dez. 2001. 
GELLNER, E. Nações e nacionalismo. Lisboa: Gradiva, 1993.

GIDDENS, A. As consequências da modernidade. São Paulo: Ed. Unesp, 1991. 188p.

GIDDENS, A. Modernidade e Identidade. Rio de Janeiro: Jorge Zahar, 2002.

GINZBURG, C. O queijo e os vermes: o cotidiano de um moleiro perseguido pela inquisição. São Paulo: Companhia das Letras, 1987.

GINZBURG, C. Os andarilhos do bem: feitiçaria e cultos agrários nos séculos XVI e XVII. São Paulo: Companhia das Letras, 1988.

GIRAUDO, C. Num só corpo. Tratado mistagógico sobre a eucaristia. São Paulo: Loyola, 2003.

GIUMBELLI, E. Zélio de Moraes e as origens da umbanda no Rio de Janeiro. In: GONÇALVES, W. Caminhos da alma. São Paulo: Summus. 2002.

GNERRE, M. Linguagem, escrita e poder. São Paulo: Martins Fontes, 1985.

GOMES, O. C. História da medicina no Brasil no século XVI. Rio de Janeiro: Instituto Brasileiro de História da Medicina, 1974.

GONTIJO, R. Identidade nacional e ensino de História: a diversidade como "patrimônio sociocultural". ABREU, M.; SOIHET, R. (Org.). Ensino de História: conceitos, temáticas e metodologias. Rio de Janeiro: Casa da Palavra, 2003.

GONZÁLEZ-UOLLA, M. The Creation of Aesthetic Plastic Surgery. New York: Springer-Verlag, 1985.

GRIN M.; MAIO, M. C. O antirracismo da ordem no pensamento de Afonso Arinos de Melo Franco. Topoi, v.14, n.26, p.33-45, jan.-jul. 2013. Disponível em: <http://www.revistatopoi.org/numeros_anteriores/topoi26/TOPOI26_2013_TOPOI_26_A03.pdf>. Acesso em: 17 ago. 2013.

GUIMARÃES, M. L. S. Historiografia e cultura histórica: notas para um debate. Ágora, Santa Cruz do Sul, v.11, n.1, p.31-47, jan.-jun. 2005.

GUIMARÃES, V. (Org.) As transferências culturais - o exemplo da imprensa na França e no Brasil. São Paulo/Campinas: Edusp/Mercado de Letras, 2012.

GUY, G. R. Linguistic variantion in brasilian portuguese: aspects of the phonology,syntax and language history. Pennsylvania, 1981, Dissertation (Ph. D) - University of Pennsylvania, 1981.

HALBWACHS, M. Les cadres sociaux de la mémoire. Paris: Presses Universitaires de France, 1952.

HALL, S. A identidade cultural na pós-modernidade. Rio de Janeiro: DP\&A, 2006. 
HALL, S. Da Diáspora. Identidades e Mediações Culturais. Belo Horizonte: Editora UFMG, 2003.

HALL, S. Quem precisa da identidade? In: SILVA, T. T. (Org.) Identidade e diferença: a perspectiva dos estudos culturais. 9.ed. Petrópolis, RJ: Vozes, 2009. p.103-133.

HARTOG, F. (Org.). A história de Homero a Santo Agostinho. Trad. Jacynto Lins Brandão. Belo Horizonte: UFMG, 2001.

HARTOG, F. (Org.). Viajantes e homens-fronteira. In: Memória de Ulisses: narrativas sobre a fronteira na Grécia antiga. Belo Horizonte: editora UFMG, 2004. (Coleção Humanitas).

HOBSBAWM, E. Introdução. In: HOBSBAWM, E.; RANGER, T. A invenção das tradições. Rio de Janeiro: Paz e Terra, 1984.

HOBSBAWM, E. História social do jazz. Rio de Janeiro: Paz e Terra, 1990.

HOBSBAWM, E. Nações e nacionalismo desde 1870. Rio de Janeiro: Paz e Terra, 1991.

HOBSBAWM, E; RANGER, T. (Org.). A Invenção das Tradições. Rio de Janeiro: Paz e Terra, 1984.

HOLANDA, S. B. História geral da civilização brasileira. O Brasil Monárquico. Tomo II. São Paulo: Difusão Europeia do Livro, 1967.

HOME, S. Assalto à cultura: utopia subversão guerrilha na (anti)arte do século XX. São Paulo: Conrad, 1999.

HOUAISS, A. O português no Brasil. 3.ed. Rio de Janeiro: Revan, 1992. [1985].

IANNI, O. As metamorfoses do escravo: apogeu e crise da escravatura no Brasil meridional. São Paulo: Hucitec; Curitiba: Scientia et Labor, 1988.

IBGE. Características étnico-raciais da população: classificações e identidades. Rio de Janeiro, 2013. Disponível em: <http://www.ibge. gov.br/home/estatistica/populacao/caracteristicas_raciais/pcerp_ classificacoes_e_identidades.pdf $>$. Acesso em: ago. 2013.

IBGE. Características étnico-raciais da população: um estudo das categorias de classificação de cor ou raça - 2008. Rio de Janeiro: Coordenação de População e Indicadores Sociais, 2011. Disponível em: <http://www.ibge.gov.br/home/estatistica/populacao/caracteristicas_raciais/PCERP2008.pdf>. Acesso em: ago. 2013.

IBGE. Censo de 2010. Disponível em: <http://www.ibge.gov.br/home/ estatistica/populacao/censo2010/default.shtm>. Acesso em: 22 mar. 2011. 
IBGE. Censo Demográfico - 2010: Características da população e dos domicílios. Resultados do universo. Rio de Janeiro: IBGE, 2011. Disponível em: <http://portal.mj.gov.br/sedh/rndh/Carta\%20do\%20 Rio.pdf>. Acesso em: ago. 2013.

ILARI, R.; BASSO, R. O português da gente: a língua que estudamos a língua que falamos. São Paulo: Contexto, 2006.

INSTITUTO DE PESQUISA E ESTUDOS AFRO-BRASILEIROS. 2013. Disponível em: <http://www.ipeafro.org.br/home/br>. Acesso em: 7 ago. 2013.

ISAIA, A. C. A hierarquia católica brasileira e o passado português. In: SZESZ, C. M. et al. Portugal-Brasil no século XIX. Sociedade, cultura e ideologia. Bauru, SP: EDUSC, 2003.

ISAIA, A. C. A república e a teleologia histórica do espiritismo. In: ISAIA, A. C.; MANOEL, I. A. Espiritismo E religiões afro-brasileiras. São Paulo: Unesp, 2012.

ISAIA, A. C. Catolicismo e autoritarismo no Rio Grande do Sul. Porto Alegre: EDIPUCRS, 1998.

ISAIA, A. C. Ordenar progredindo: a obra dos intelectuais de Umbanda no Brasil da primeira metade do século XX. Anos 90. Porto Alegre, UFRGS, v.11, 1999.

ISAIA, A. C. Religiões afro-brasileiras, sincretismo e representação triádica da nacionalidade no discurso católico brasileiro pré-conciliar. Debates do NER. 12 (19), p.29-51, 2011.

ISAIA, A. C. Umbanda, intelectuais e nacionalismo no Brasil. Fênix. Revista de História e estudos culturais. 9(9), p.1-22, 2012.

JANOTTI JR., J. Aumenta que isso ai é rock'n'roll-mídia, gênero musical e identidade. Rio de Janeiro: E-Papers Serviços Editoriais, 2003.

JOBIM, J. M. C. "Discurso com que José Martins da Cruz Jobim Abriu o Seu Curso de Medicina Legal na Faculdade de Medicina do Rio de Janeiro". Revista Médica Fluminense, n.1, 1836. v.II.

KATO, M. A. Apresentação: "Como e por que escavar"? In: ROBERTS, I.; KATO, M. A. (Org.). Português brasileiro: uma viagem diacrônica. Campinas: Unicamp, 1993. p.13-27.

KELNER, M.; WELLMAN, B. Complementary and alternative medicine: challenge and change. Amsterdam: Harwood Academic Publishers, 2000 .

KUMAR, K. Modernidade. In: OUTHWAITE, W; BOTTOMORE, T. Dicionário do pensamento social do século XX. Rio de Janeiro: Jorge Zahar, 1996. 990p.

LEITE, D. M. O caráter nacional brasileiro: história de uma ideologia. 6.ed. rev. São Paulo: Ed. Unesp, 2002. 
LEITE, S. (S. J.). A minha vocação. Revista da Academia Brasileira de Letras. v.60. Rio de Janeiro, jul.-dez. 1940.

LEITE, S. (S. J.). Os jesuítas no Brasil e a medicina. Lisboa: Separata da Revista Petrus Nominus, 1936.

LIMA, L. C. O controle do imaginário. São Paulo: Brasiliense, 1984.

LLOBERA, J. R. El dios de la modernidad. El desarrollo del nacionalismo en Europa occidental. Barcelona: Editorial Anagrama, 1996.

LOEB, R. História da cirurgia plástica brasileira: 150 anos de evolução. Rio de Janeiro: MEDSI, 1993.

LUCA, T. R. A Revista do Brasil: um diagnóstico para a (N)ação. São Paulo: Unesp, 1999.

LUCCHESI, D. História do contato entre línguas no Brasil. In: LUCCHESI, D.; BAXTER, A.; RIBEIRO, I. (Org.). O português afro-brasileiro. Salvador: EDUFBA, 2009. p.41-73.

LUCCOCK, J. Notas sobre o Rio de Janeiro e Partes Meridionais do Brasil. Trad. Milton da Silva Rodrigues. Belo Horizonte: Itatiaia; São Paulo: Edusp, 1975.

MACEDO, J. M. Os dois amores. Rio de Janeiro: W. M. Jackson, 1964.

MACHADO, R. et. al. Danação da Norma: medicina social e constituição da psiquiatria no Brasil. Rio de Janeiro: Graal, 1978.

MAGGIE, Y.; FRY, P. A reserva de vagas para negros nas universidades brasileiras. Estudos avançados, v.18, n.50, p.77-80, 2004.

MAIGRET, E. Sociologia da Comunicação e das mídias. São Paulo: Senac, 2010.

MAIO, M. C. O projeto UNESCO e a agenda das Ciências Sociais no Brasil dos anos 40 e 50. Revista Brasileira de Ciência Sociais, v.14, n.41, out. 1999.

MAIO, M. C. Relações raciais e desenvolvimento na sociologia de Costa Pinto. In: BOTELHO, A.; SCHWARCZ, L. M. (Org.). Um enigma chamado Brasil. São Paulo: Companhia das Letras, 2009. p.224-337.

MAIO, M. C.; SANTOS, R. V. (Org.): Raça, ciência e sociedade. Rio de Janeiro: Fiocruz, 1996.

MANIFESTO DA REFLEXÃO TEOLÓGICA PENTESCOSTAL DAS ASSEMBLEIAS DE DEUS NO BRASIL. Disponível em <http:// www.cpadnews.com.br/integra.php? $\mathrm{s}=12 \& \mathrm{i}=4330>$. Acesso em: 30 jun. 2011.

MARCHA ZUMBI. Por uma política nacional de combate ao racismo e à desigualdade racial: Marcha Zumbi contra o racismo, pela cidadania e a vida. Brasília: Cultura Gráfica e Ed., 1996. 
MARCHI, E. A utopia das desigualdades harmônicas. Revista de Ciências Humanas, n.3. Curitiba: Editora da UFPR, 1994.

MARQUES, V. R. B. Natureza em boiões. Medicinas e boticários no Brasil setecentista. Campinas: Unicamp, 1999.

MARTIUS, C. F. Von. Como se deve escrever a História do Brasil. Belo Horizonte: Itatiaia; São Paulo: Edusp, 1982.

MATTOS E SILVA, R. V. De fontes sócio-históricas para a história social linguística do Brasil: em busca de indícios. In: MATTOS E SILVA, R. V. (Org.). Para a história do português brasileiro. São Paulo: Humanitas, 2001. v.II. p.275-301.

MATTOS E SILVA, R. V. Uma compreensão histórica do português brasileiro. Velhos problemas repensados. In: CARDOSO, S. A. M. et al. (Org.). Quinhentos anos de história linguística do Brasil. Salvador: Secretaria de Cultura e Turismo do Estado da Bahia, 2006. p.219-254. MATTOS E SILVA, R. V. Uma interpretação para a generalizada difusão da língua portuguesa no território brasileiro. Gragoatá, Niterói, n.9, p.11-27, 2000.

MAUSS, M. As técnicas corporais. In: MAUSS, M. Sociologia e antropologia. São Paulo: EPU/Edusp, 1974.

MAUSS, M. Sociologia e Antropologia. São Paulo: Cosac Naify, 2003.

MENDES, J. A. Governo de mineiros mui necessario para os que vivem distantes de professores seis, oito dez, e mais legoas, padecendo por esta causa os seus domésticos e escravos queixas, que pela dilação dos remédios se fazem incuráveis, e a mais das vezes mortais. Lisboa: Off Antonio Rodrigues Galhardo, 1770.

MENSAGEM DO EPISCOPADO NAGIONAL A GETÚLIO VARGAS. Rio de Janeiro, 22 out. 1931. (Arquivo Getúlio Vargas, CPDOC-FGV-RJ. Ref. GV31.10.12/2.

MOEHLECKE, S. Ação afirmativa: História e debates no Brasil. Cadernos de Pesquisa, n.117, nov. 2002.

MONTE, J. P. X. O homem medico de si mesmo, ou sciencia, e arte nova de conservar cada hum a si próprio a saúde, e destruir a sua doenca, dirigida ao bem comum. Lisboa: Na Officina de Antonio Vicente da Silva, 1760.

MONTEIRO, H. O ressurgimento do Movimento Negro no Rio de Janeiro na década de 1970. 1999. Dissertação (mestrado) - IFCS, Universidade Federal do Rio de Janeiro, Rio de Janeiro, 1999.

MORAES, Z. F. Depoimento. Disponível em: <http://www.youtube. com/watch? $=$ Y8zSqvql5GA>. Acesso em: 30 jul. 2013. 
MOTA, G. G. (Org.). A viagem incompleta. A experiência brasileira (1500-2000). Formação: histórias. 2.ed. São Paulo: Senac, 2000. [1.ed. 1999].

MOTA, L. D. (Org.). Introdução ao Brasil: um banquete no trópico, 1. 4.ed. São Paulo: Senac, 2004. [2.ed. 2002; 1.ed. 1999].

MOTTA, D. Carlos Carmelo de Vasconcelos. Panorama religioso do Brasil no XXXVI Congresso Eucarístico Internacional. Boletim Eclesiástico. jul.-ago, 1955.

MULLER, L. S. As contas do meu rosário são balas de artilharia: irmandade, jornal e associações negras em Porto Alegre (1889-1920). 1999. Dissertação (Mestrado) - Faculdade de Filosofia e Ciências Humanas, Pontifícia Universidade Católica do Rio Grande do Sul, Porto Alegre, 1999.

MUNANGA, K. Políticas de ação afirmativa em benefício da população negra no brasil - um ponto de vista em defesa de cotas. Revista espaço acadêmico, a.2, n.22, p.1-10, mar. 2003. Disponível em: <http:// www.espacoacademico.com.br/022/22cmunanga.htm>. Acesso em: 5 ago. 2013.

NAPOLITANO, M.; WASSERMAN, M. C. Desde que o samba é samba: a questão das origens no debate historiográfico sobre a música popular brasileira. Revista Brasileira de História. São Paulo: v.20, n.39, p.167-189, 2000.

NARO, A. J.; SCHERRE, M. M. P. Garimpo das origens do português brasileiro. São Paulo: Parábola, 2007.

NASCIMENTO, A. O Centenário da Academia Nacional de Medicina do Rio de Janeiro - 1829-1929. Rio de Janeiro: Imprensa Nacional, 1929.

NASCIMENTO, A. O negro revoltado. Rio de Janeiro: GRD, 1968.

NASCIMENTO, A. Teatro Experimental do Negro: trajetórias e reflexões. Estudos Avançados, v.18, n.50, p.209-224, 2004.

NAVA, P. Capítulos da história da medicina no Brasil. São Paulo: Oficina do Livro Rubens Borba de Moraes, 2003.

NEDER, A. O estudo cultural da música popular brasileira: dois problemas e uma contribuição. Per Musi, Belo Horizonte, n.22, 2010, p.181-195.

NICOLAZZI, F. Um estilo de História: a viagem, a memória, o ensaio: sobre Casa-grade e senzala e a representação do passado. São Paulo: Ed. Unesp, 2011.

NIRANJANA, T. Siting translation: history, post-structuralism, and the colonial context. Berkeley: University of California Press, 1992. 
NOVAES, A. Invenção e crise do Estado-nação. In: NOVAES, A. A crise do Estado-Nação. Rio de Janeiro: Civilização Brasileira, 2003. p.9-22.

O BEREANO. Disponível em: <http://obereano.blogspot.com. br/2008/09/verdadeira-histria-das-assemblias-de.html>. Acesso em: 2 jul. 2013.

OLIVA, A. R. Lições sobre a África. 2007. Tese (Doutorado) - Universidade de Brasília, Brasília, 2007.

OLIVEIRA, G. M. Brasileiro fala português: monolinguismo e preconceito linguístico. In: SILVA, F. L.; MOURA, H. M M. (Org.). O direito à fala: a questão do preconceito linguístico. Florianópolis: Insular, 2000. p.83-92.

OLIVEIRA, G. M. Matrizes da língua portuguesa no Brasil meridional 1680-1830. In: MATTOS E SILVA, R. V. (Org.). Para a história do português brasileiro. São Paulo: Humanitas, 2001. v.II, p.401-420.

OLIVEIRA, G. M. Última fronteira: a língua portuguesa no Brasil meridional. Reflexões sobre um corpus linguístico diacrônico. In: CASTILHO, A. T. (Org.). Para a história do português brasileiro. São Paulo: Humanitas, 1998. v.I. p.211-227.

OLIVEIRA, J. A. Umbanda Cristã e Brasileira. Pesquisa, análise, doutrina. Rio de Janeiro: Ediouro, s.d.

OLIVEIRA, J. As Assembleias de Deus no Brasil. Sumário Histórico Ilustrado. Rio de Janeiro: Casa Publicadora das Assembleias de Deus, 1997.

OLIVEIRA, L. L. A questão nacional na Primeira República. São Paulo; Brasília: Brasiliense; CNPq, 1990. 208p.

ORLANDI, E. P. (Org.) Discurso Fundador: a formação do país e a construção da identidade nacional. 2.ed. Campinas: Pontes, 2001.

ORTIZ, R. A morte branca do feiticeiro negro. Umbanda e sociedade brasileira. São Paulo: Brasiliense, 1988.

ORTIZ, R. Românticos e folcloristas. São Paulo: Olho d'Água, 1992.

PACHECO, J. Q.; SILVA, M. N. O Negro na universidade: o direito à inclusão. Brasília: Fundação Cultural Palmares, 2007.

PAIVA, E. F. História E Imagens. Belo Horizonte: Autêntica, 2002.

PALLARES-BURKE, M. L. Gilberto Freyre: um vitoriano nos trópicos. São Paulo: Ed. Unesp, 2005.

PANTOJA, V. Amazônia: Terra de missão. Bispos ultramontanos e missionários protestantes na Belém do século XIX. Debates do NER, 13(21), p. 95-122.

PENA, S. D. Retrato molecular do Brasil. Ciência Hoje, v.27, n.159, p.1625, 2000. 
PENA, S. D.; BORTOLINI, M. C. Pode a genética definir quem deve se beneficiar das cotas universitárias e demais ações afirmativas? Estudos Avançados, v.18, n.50, p.31-50, 2004.

PEREIRA, A. A. O Mundo Negro: a constituição do Movimento Negro contemporâneo no Brasil (1970-1995). 2010. Tese (Doutorado) - Universidade Federal Fluminense, Niterói, 2010. Disponível em: <http:// www.historia.uff.br/stricto/td/1254.pdf>._Acesso em: 1 ago. 2013.

PESSOA DE CASTRO, I. A matriz africana no português do Brasil. In: CARDOSO, S. A. M. et al. (Org.). Quinhentos anos de história linguística do Brasil. Salvador: Secretaria de Cultura e Turismo do Estado da Bahia, 2006. p.81-116.

PIERSON, D. Brancos e pretos na Bahia. São Paulo: Cia. Editora Nacional, 1971.

PINHEIRO, A. O. Revista Espiritual de Umbanda: Tradição e tensões no campo umbandista. Florianópolis: UFSC, Dissertação (Mestrado em História), 2009.

PINTO, L. A. C. O Negro no Rio de Janeiro: relações de raças numa sociedade em mudança. 2. ed. Rio de Janeiro: Editora da UFRJ, 1998. Disponível em: <http://es.scribd.com/doc/113255659/COSTAPINTO-1998-O-Negro-No-Rio-de-Janeiro>. Acesso em: 10 ago. 2013.

PRADO JR., C. História econômica do Brasil. 14.ed. São Paulo: Brasiliense, 1971. [1945].

PROST, A. Social e Cultural Indissociavelmente. In: RIOUX, J. P.; SIRINELLI, J. F. (Dirs.) Para uma História Cultural. Lisboa: Estampa, 1999.

QUEIROZ, M. I. P. Identidade Nacional, religião e expressões culturais. In: SACHS, V. (Org.). Brasil \& Estados Unidos. Religião e identidade nacional. Rio de Janeiro: Graal, 1988.

QUEIROZ, S. R. R. Aspectos ideológicos da escravidão. Estudos Econômicos. São Paulo, v.13, n.1, 1983.

QUEIROZ, S. R. R. Escravidão negra em São Paulo: um estudo das tensões provocadas pelo escravismo no século XIX. Rio de Janeiro: José Olympio, 1977.

QUEIROZ, S. R. R. Rebeldia escrava e historiografia. Consciência. Palmas, p.49-80, jan.-jun., 1988.

RAEDERS, G. O inimigo cordial do Brasil: o Conde de Gobineau no Brasil. Rio de Janeiro: Paz e Terra, 1988. 
RAMOS, J. História do português brasileiro: perspectivas. In: CASTILHO, A. T. (Org.). Para a história do português brasileiro. São Paulo: Humanitas, 1998. v.I. p.153-167.

REIS, J. C. As identidades do Brasil: de Varnhagem a FHC. 5.ed. Rio de Janeiro: FGV, 2002. [3.ed. 2000; 1.ed. 1999.]

REIS, J. C. As identidades do Brasil 2: de Calmon a Bomfim - a favor do Brasil: direita ou esquerda? Rio de Janeiro: Fundação Getúlio Vargas, 2006.

REIS, J. J. (Org.). Escravidão e invenção da liberdade. Rio de Janeiro: Brasiliense, 1988.

RENAN, E. O que é uma nação? Revista Plural, Sociologia, USP, v.4, p.154-175, 1을 semestre de 1997.

RIBEIRO, E. N. Eurico Alfredo Nelson (1862-1939) e a inserção dos batistas em Belém do Pará. São Bernardo do Campo: Programa de Pós-Graduação em Ciências da Religião, Dissertação (Mestrado), 2011.

RIBEIRO, J. História do Brasil. 15.ed. rev. por Joaquim Ribeiro. Rio de Janeiro: Livraria São José, 1954.

RIBEIRO, L. Medicina no Brasil Colonial. Rio de Janeiro: GB, 1971.

RIBEIRO, M. M. A ciência dos trópicos: a arte médica no Brasil do século XVIII. Hucitec, 1997.

RIBEIRO, R. A nação na Europa - breve discussão sobre identidade nacional, nacionalismo e supranacionalismo. Cadernos do Noroeste. Série sociologia. 22:1-2, 2004b, p.85-96.

RIOS, F. M. Institucionalização do Movimento Negro no Brasil contemporâneo. 2010. Dissertação (Mestrado em Sociologia) - Universidade de São Paulo, São Paulo, 2010.

ROCHA, A. T. Princípios de Filosofia Médica. Tese apresentada à Faculdade de Medicina da Bahia, 1846.

ROCHA, J. C. C. (Org.). Nenhum Brasil existe: pequena enciclopédia. Rio de Janeiro: Topbooks, 2003.

ROCHA, M. R. Etíope resgatado, empenhado, sustentado, corrigido, instruído e libertado [...]. Lisboa: Na Officina Patriarcal de Francisco Luiz Ameno, 1758.

RODRIGUES, A. D. As línguas gerais sul-americanas. Papia: revista de crioulos de base ibérica, Brasília, v.4, n.2, p.6-18, 1996.

RODRIGUES, A. D. As outras línguas da colonização do Brasil. In: CARDOSO, S. A. M. et al. (Org.). Quinhentos anos de história linguística do Brasil. Salvador: Secretaria de Cultura e Turismo do Estado da Bahia, 2006. p.145-161. 
RODRIGUES, A. D. Linguas brasileiras: para o conhecimento das línguas indígenas. São Paulo: Loyola, 1994.

ROSA, A.; BELLELLI, G.; BAKHURST, D. Representaciones del pasado, cultura personal e identidad nacional. Educação e Pesquisa, São Paulo, v.34, n.1, p.167-195, jan.-abr. 2008.

ROVISCO, M. L. Reavaliando as narrativas da nação - identidade nacional e diferença cultural. Actas do IV Congresso Português de Sociologia. Lisboa: Associação Portuguesa de Sociologia, dez. 2003.

RUSSELL-WOOD, A. J. R. Fidalgos e filantropos. A Santa Casa da Misericórdia da Bahia, 1150-1755. Brasília: Ed. UnB, 1981.

SABOIA, G. V.; PORTO, A. V. A conferência mundial de Durban e o Brasil. Direitos Humanos: atualizando o debate. Itamaray, 2002. p.21-26. Disponível em: <http://dc.itamaraty.gov.br/imagens-e-textos/DH-Portugues03.pdf>. Acesso em: 15 ago. 2013.

SACHS, I.; VILHEIM, J.; PINHEIRO, P. S. (Org.). Brasil: um século de transformação. São Paulo: Companhia das Letras, 2001.

SADER, E. Quando novos personagens entram em cena: experiências e lutas dos trabalhadores da Grande São Paulo (1970-1980). 4.ed. São Paulo: Paz e Terra, 2001.

SANTAMARIA, Y. O Estado-Nação - história de um modelo. In: CORDELIER, S. (Coord.). Nações e nacionalismos. Lisboa: publicações Dom Quixote, 1998.

SANTIAGO, S. (Org.). Intérpretes do Brasil. 3v. Rio de Janeiro: Nova Aguilar, 2000.

SANTONI-RUGIU, P. A History Of Plastic Surgery. Berlin; London: Springer, 2007.

SANTOS FILHO, L. História da medicina no Brasil. São Paulo: Brasiliense, 1947.

SANTOS FILHO, L. História geral da medicina brasileira. São Paulo: Edusp; Hucitec, 1991.

SANTOS FILHO, L. Medicina colonial. In: HOLANDA, S. B. História Geral da Civilização Brasileira (t.I, v.2) - São Paulo: Difel, 1960.

SANTOS FILHO, L. Pequena história da medicina brasileira. São Paulo: DESA; Edusp, 1966.

SANTOS, J. M. C. A inteligência do homem explicada pelo sistema frenológico. Tese apresentada à Faculdade de Medicina do Rio de Janeiro, 1846.

SANTOS, J. R.; BARBOSA, W. N. Atrás do muro da noite: dinâmica das culturas afro-brasileiras. Brasília: Ministério da Cultura; Fundação Cultural Palmares, 1994. 
SARGES, M. N. Belém: riquezas produzindo a belle époque (1870-1912). Belém: Paka-Tatu, 2000.

SCHERRE, M. M. P. Doa-se lindos filhotes de poodle: variação linguística, mídia e preconceito. São Paulo: Parábola, 2005.

SCHWARCZ, L. M. Estado sem Nação: a criação de uma memória oficial no Brasil do Segundo Reinado. In: NOVAES, A (Org.). A crise do Estado-Nação. Rio de Janeiro: Civilização Brasileira, 2003. p.349-396. SCHWARCZ, L. M. Imaginar é difícil (porém necessário). In: ANDERSON, B. Comunidades imaginadas: reflexões sobre a origem e a difusão do nacionalismo. São Paulo: Companhia das Letras, 2008.

SCHWARCZ, L. M. O espetáculo das raças: cientistas, instituições e questão racial no Brasil, 1870-1930. São Paulo: Companhia das Letras, 1993.

SCHWARCZ, L. M. Prefácio. In: SIMAN, L. M. C.; FONSECA, T. N. L (Org.). Inaugurando a História e Construindo a Nação. Belo Horizonte: Autêntica, 2001. p.7-16.

SCHWARCZ, L. M.; BOTELHO, A. Um enigma chamado Brasil: 29 intérpretes e um país. São Paulo: Companhia das Letras, 2009.

SCHWARTZ, S. B. Escravos, roceiros e rebeldes. Bauru: Edusc, 2001.

SCHWARTZ, S. B. Segredos internos: engenhos e escravos na sociedade colonial, 1550-1835. São Paulo: Companhia das Letras, 1988.

SCHWARZ, R. Que horas são?: ensaios. São Paulo: Companhia das Letras, 1997.

SCWARTZ, R. A situação da cultura diante dos protestos de rua. Blog da Boitempo 23/07/2013. Disponível em: <http://blogdaboitempo.com. br>. Acesso em: 25 jul. 2013.

SELL, C. E.; BRÜSEKE, F. J. Mística e sociedade. São Paulo: Paulinas, 2006. SEMPRINI, A. Multiculturalismo. Bauru: Edusc, 1999.

SEQUEIRA, A. Botica preciosa, e tesouro precioso da Lapa. Em que como em botica, e tesouro se acham todos os remédios para o corpo, e para a alma, e para a vida, E uma receita das vocações dos santos para remédio de todas as enfermidades, e vários remédios, e milagres de Nossa Senhora da Lapa, e muitas novenas, devoções, e avisos importantes para os pais de família ensinarem a doutrina cristã a seus filhos, e criados. Lisboa: Of. Miguel Rodrigues, 1754.

SERRANO, J. Sacerdos Magnus. In: SERRANO, J. et al. Festas jubilares e sacerdotais (1914-1926). [s.n.t.].

SEYFETH, G. O futuro era branco. Revista de História da Biblioteca Nacional, ed.69, jun. 2011. Disponível em: <http://www.revistadehistoria.com.br/revista/edicao/69>. Acesso em: 15 ago. 2013. 
SILVA, F. L. Espiritismo. História e Poder (1938-1949). Londrina: Eduel, 2005. SILVA, J. A União dos Homens de Cor: aspectos do Movimento Negro dos anos 40 e 50. Estudos Afro-asiáticos, v.25, n.2, p.215-235, 2003. Disponível em: <http://www.scielo.br/pdf/eaa/v25n2/a02v25n2. pdf $>$. Acesso em: 9 ago. 2013.

SILVA, T. T. (Org.) Identidade e diferença: a perspectiva dos estudos culturais. 9.ed. Petrópolis: Vozes, 2009a.

SILVA, T. T. A produção social da identidade e da diferença. In: SILVA, T. T. (Org.) Identidade e diferença: a perspectiva dos estudos culturais. 9.ed. Petrópolis: Vozes, 2009b. p.17-102.

SMITH, A. D. A identidade nacional. Lisboa: Gradiva, 1997.

SMITH, A. O nacionalismo e os historiadores. In: BALAKRISHNAN, G. (Org.). Um mapa da questão nacional. Rio de Janeiro: Contraponto, 2000. p.185-208.

STUDART, G. Pathologia historica brazileira. Documentos para a história da pestilência da bicha ou males. Fortaleza: Biblioteca Básica Cearense, 1997.

TARALLO, F. Diagnosticando uma gramática brasileira: o português d'aquém e d'além-mar ao final do século XIX. In: ROBERTS, I.; KATO, M. A. (Org.). Português brasileiro: uma viagem diacrônica. Campinas: Ed. Unicamp, 1993b. p.69-105.

TARALLO, F. Sobre a alegada origem crioula do português brasileiro: mudanças sintáticas aleatórias. In: ROBERTS, I.; KATO, M. A. (Org.). Português brasileiro: uma viagem diacrônica. Campinas: Ed. Unicamp, 1993a. p.35-68.

TELLES, E. Racismo à Brasileira: uma nova perspectiva sociológica. Rio de Janeiro: Relume Dumará; Fundação Ford, 2003.

THIESSE, A. Ficções Criadoras: as Identidades Nacionais. Anos 90, Porto Alegre, n.15, 2001-2002.

TODOROV, T. A conquista da América: a questão do outro. São Paulo: Martins Fontes, 1982.

TODOROV, T. Nós e os outros: a reflexão francesa sobre a diversidade humana. Rio de Janeiro: Jorge Zahar, 1993.

TRINDADE, D. F. Umbanda e sua história. São Paulo: Ícone, 1991.

VENTURA, R. Escritores, escravos e mestiços em um país tropical. Raça e natureza na cultura brasileira (1825-1933). 1988. Tese (Doutorado)Universidade de São Paulo, São Paulo, 1988.

VIANNA, H. O mistério do samba. Rio de Janeiro: Jorge Zahar; Ed. UFRJ, 1995. 
VIANNA, O. Populações meridionais do Brasil: História, organização, psicologia. 2v. Belo Horizonte: Itatiaia; 1987.

VIANNA, O. Raça e assimilação. São Paulo: Cia. Editora Nacional, 1938.

VIDE, S. M. Constituições primeiras do Arcebispado da Bahia feitas, e ordenadas pelo Illustrissimo, e Reverendissimo Senhor D. Sebastião Monteiro da Vide: propostas, e aceitas em o Synodo Diocesano, que o dito Senhor celebrou em 12 de junho do anno de 1707.

VIEIRA, A. Sermões. v.5. Erechim: Edelbra, 1998.

VIEIRA, D. G. O protestantismo, a maçonaria e a questão religiosa no Brasil. Brasília: UnB, 1980.

VINGREN, I. Diário do pioneiro. Rio de Janeiro: Casa Publicadora das Assembleias de Deus, 2011 [1973].

VISCONTI, E. A trajetória da guitarra elétrica no Brasil. In: Músicos do Brasil: uma enciclopédia instrumental. 2009. Disponível em: <http:// ensaios.musicodobrasil.com.br/eduardovisconti-a-trajetoria-da-guitarra-eletrica-no-brasil.pdf $>$.

VITRAL, L. Língua geral versus língua portuguesa: a influência do "processo civilizatório". In: MATTOS E SILVA, R. V. (Org.). Para a história do português brasileiro. São Paulo: Humanitas, 2001. v.II. p.303-315.

WARBURTON, N. Elementos Básicos de Filosofia. 2. ed. Lisboa: Gradiva, 2007.

WEBER, M. Economia e Sociedade: fundamentos da sociologia compreensiva. Brasília: Ed. UnB, 2009 [1991].

WEBER, M. Ensaios de sociologia e outros escritos. São Paulo: Abril Cultural, 1974. (Os pensadores, 37.)

WEHLING, A. A invenção da história: estudos sobre o historicismo. Rio de Janeiro: Editoria da Universidade Gama Filho; Niterói: Editora da Universidade Federal Fluminense, 1994.

WENDEN, C. W. Nação e cidadania, um par de associados-rivais. In: CORDELIER, S. (Coord.). Nações e nacionalismos. Lisboa: Dom Quixote, 1998.

WHO global atlas of traditional, complementary and alternative medicine. Kobe: Japan, 2005.

WOLFENSON, M. Um século de cirurgia plástica no Brasil: mestres vivos da cirurgia plástica e suas escolas. Porto Alegre: Imagens da Terra, 2005.

WOODWARD, K. Identidade e diferença: uma introdução teórica e conceitual. In: SILVA, T. T. (Org.) Identidade e diferença: a perspectiva dos estudos culturais. 9.ed. Petrópolis: Vozes, 2009. 
XAVIER, F. C. Brasil coração do mundo pátria do evangelho. Rio de Janeiro: FEB, 1998.

ZÁGARI, M. R. L. Os falares mineiros: esboço de um atlas linguístico de Minas Gerais. In: AGUILERA, V. A. (Org.). A geolinguística no Brasil: trilhas seguidas, caminhos a percorrer. Londrina: Ed. UEL, 2005. p.45-72. [1998. p.31-54.].

ŽIŽEK, S. Problemas no Paraíso: artigo de Slavoj Žižek sobre as manifestações que tomaram as ruas do Brasil. Blog da Boitempo, 5 jul. 2013. Disponível em: <http://blogdaboitempo.com.br>. Acesso em: 6 jul. 2013. 
SOBRE O LIVRO

Formato: $14 \times 21 \mathrm{~cm}$

Mancha: 23,7 x 42,5 paicas

Tipologia: Horley Old Style 11/15

Papel: Offset $75 \mathrm{~g} / \mathrm{m}^{2}$ (miolo)

Cartão Supremo $250 \mathrm{~g} / \mathrm{m}^{2}$ (capa)

1̄a edição: 2014

EQUIPE DE REALIZAÇÃO

Capa

Grão Editorial

Edição de Texto

Miguel Yoshida (Copidesque)

Carmen Costa (Revisão)

Editoração Eletrônica

Eduardo Seiji Seki

Assistência Editorial

Alberto Bononi 
A coleção Desafios Contemporâneos proposta pela Pró-Reitoria de Pesquisa (PROPe) da Unesp tem por objetivo disponibilizar, em linguagem acessível aos não familiarizados com o jargão dominante nos estudos especializados e sem prejuízo para o rigor científico, ensaios a respeito de temas de amplo interesse da sociedade brasileira. Assim, a universidade cumpre uma de suas tarefas essenciais: a difusão dos resultados do conhecimento que produz.

Neste volume, dedicado às questões sociais, os autores enfrentaram a difícil tarefa de lançar um olhar panorâmico sobre a complexa questão da identidade brasileira, sem perder de vista a maneira como a temática se expressa nos dilemas enfrentados nos dias que correm. 